

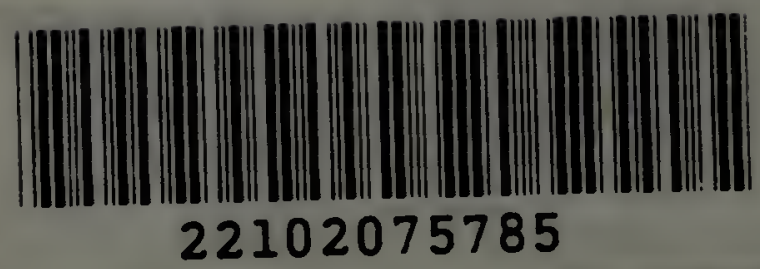


By Rolnev Gasner 


\section{Dr. Iaylor
with She farners
bur wister. Lee 21 "18\%6}

NATURAL HISTORY

OF THE

INLAND AND LITTORAL

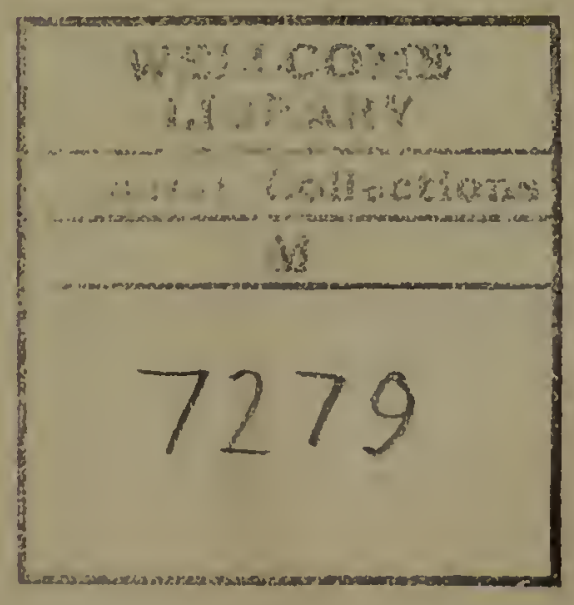


LONDON

PRINAED BY SPOTTISWOODE AND CU.

NEW-STREET SQUARE 


\title{
HOLIDAY EXCURSIONS
}

\author{
OF \\ A NATURALIST
}

FORMING

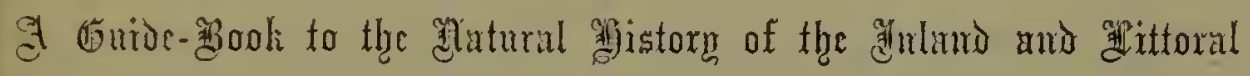

LONDON

ROBERT HARDWICKE, 192 PICCADILLY 


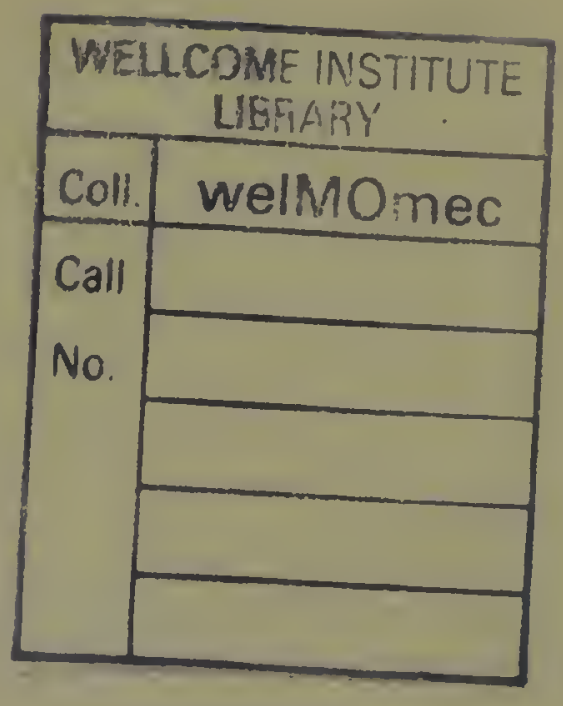


TO

\section{HIS GENTLE COMPANION}

IN MOST OF THE EXCURSIONS DESCRIBED

Ulyis a dittle 皱ooli

IS DEDICATED BY HER HUSBAND

THE AUTHOR 



\section{CONTENTS.}

\section{CHAP'TER I.}

THE INLANDS.

Farly Pursuits. - Doredale. - The Peak. - Craven. - The

Lakes.-Botany . . . . . . .

\section{CHAPTER II.}

THE SEABOARD.

London.-Sheppey.-Kent.-Hastings. - The Isle of Wight. -Corfe Castle.-Marine Zoology . . . .

\section{CHAPTER III.}

\section{'THE ISLAND.}

Liverpool.-The Isle of Man._-Douglas._The Manx.Dredging.-The Calf.-Peel.-Fish, \&c.

\section{CHAPTER IV.}

THE MOUNTAINS.

Chester.-The Ormesheads.-Natural History.-Tho Menai. -The South Stack.-Pwllheli.-The IIell's Mouth.Snowdonia

\section{CHAPTER V.}

THE PENINSULA.

Hay Time.-Gower. - Cefn-Bryn. - Oxwich Bay. - The Wormshead.-Swansea 
CHAPTER VI.

THE LAND'S END AND ITS BATS.

P'enzance.-Sit. Micheel's Mount. - The Lizard.-The Land's End.-St. Ires.-Antiquities.-Productions of Land and Sea.

\section{CHAPTER VII.}

THE HighlaNDS (A GLIMPSE OT).

Edinburgh. - Aberdeen. - The British Association. - Balmoral.-Oban.-Loch Awe.-Glenco.-Ben Nevis.-Iona. -Staffa.-Sliye.-Glasgow . . . . . .

\section{CHAPTER VIII.}

ABROAD.

ricardy.-Paris.-A Revolution. - Jardin des Plantes. A Tramp on the Upper Rhine, and through Switzerland

\section{CHAPTER IX.}

ACross THE CHANNEI، AGAIX.

I Larre.-Fécamp.-The Abbey-Church.-Rouen. - Forest: and the Seine-Caen.-Geology-Bayeux.-The Calvados Coast

\section{CIAPTER I.}

NEARER HOME-AT HOME-WINTER HVININGS.

Challi Hills.-Tring.-Cheshire Mosses.-The Microscope. -Desmids.-Diatoms.-Infusoria. - Rotifera . . . 22,

\section{CHAPTER XI.}

\section{UNDERGROUND-FOSSIL-HUNTING.}

Freehold and Copylold.-Coal and Iron Míagnates.-Geological Theorizing. - Ichthyolites. - Ichthyodurolites.Coal-plants 


\section{HOLIDAY EXCURSIONS}

OF

\section{A NATURALIST.}

\section{CHAPTER I.}

THE INLANDS.

The FOLLOWING CHAPTERs are put together for the most part from written memoranda, seldom from unaided memory, by one of a class of happy individuals who, through life, derive a chief source of enjoyment from intercourse with Nature in her works. The rock, the wood, the stream, the lake, the morass, have each a thousand attractions for him, and many an enduring care or sharper disappointment has been softened down by the soothing influence of this enjoyment, which is near at hand for most men, unless their minds are so constituted, or, rather, so absorbed in other pursuits, that Nature smiles in vain for them. His botanical and zoological rambles began early in life. There was not a lane or bosky dell for miles around which he had not well explored. Each ramble, some more distant hill or wood tempted him on. He was acquainted, ' by sight,' with all that the neighbourhood afforded in his favourite pursuits. The neat, warm, mossy nest of the Spink, or Pied 
Finch, and the more curious one still of the Bottle Tit, first excited his attention. Next he found the nest of a relative of the latter, the Marsh Titmouse, in a hole hollowed out by the little bird himself, near the top of an osier stake, and, little folks being notoriously cunning, he always takes care, to prevent detection, to carry off the bits of wood which he works out. Then there was that of the Reed Warbler, at a mere not far distant, being stilted (and for the same reason as the primeval lake-dwellings) above the water, bound to several of the reedstalks. He obtained the beautiful transparent eggss of the Kingfisher from its less delectable nest, formed of minute fish-bones, and found the Dipper's snug' dwelling at an old bridge over one of the neighbouring streams. Mr. Yarrell never saw this last bird alive, though in Staffordshire Water Ousels, as they are generally called, are not uncommon, filying, with short wing and loud whistle, pretty swiftly along the streams.

Assuming, for the present at least, the first person, I very early knew the notes of all the little songsters of the neighbourhood, recognising them, however, generally under their provincial names-of the Great Tit, the Saw-rvhetter, or Lawyer, heard at the very beginning of the year on the top of a high tree, the first name characteristic enough of its peculiar note, the second of I know not what, unless of its garrulity-of the Willow Wren, a slurred, descending, chromatic scale, with a final flourish diminucndo, not, however, very different from the note of the Chaffinch-the simple one of the Chiff-chaff, expressed by its name, which keeps further from the town than its cousin the Willow Wren, yet boldly hops about the rows of peas in cottage gardens, no doubt from a good conscience, for it does not touch the peas, but 
only the insects - the continuous, hurried, yet mellow note of the Garden Warbler, characteristic of the sweetest part of the year-that of Peggy Whitethroat, very inferior to the last, yet equally hurried, and seeming to express that it is very busy, too busy to be interrupted, in the hedgerow-and that of the Goldfinch, so called, in reality the Yellowhammer (the true Goldfinch being here termed the Seven-coloured or Red Linnet), and that is easily set in musical notes, being a succession of semiquavers staccato, then a rise of a lengthened half-note, ending with the prolonged first-in fact, one of the Gregorian chants. The Biack-headed Bunting we call the Reed Sparrow, a russety but rather handsome fellow, found along the streams. I did not fail to notice that the Sedge Warbler and the Corncrake were nocturnal songsters, and indeed the Cuckoo too on warm nights; that the Wheatear builds on deserted coal-pit lows, and the Swallow down the shafts of old mines. I could call, by certain devices, the Corncrake or the Grouse, though I never shot either, and had formed acquaintance with the comical young of Gledes, Owlets, and Hedgehogs, besides keeping Snakes and Blindworms. For us the Nole was the Saxon Mouldewarpe, and the Shrew the Nurserow.

Having naturally a vein of the tender in my disposition, I seldom robbed a bird of its whole lateh ; once, lowever, I did rob the dupe Titlark of its Cuckco chick, which I attempted in vain to rea: But I have known others to be more successful, and at present I see one almost daily, towards the end of October, which was caught in the summer fullfledged. For a day or two after its capture it was kept in a distant place, but then brought back to about a mile from the spot where it was hatched, 
and placed in a cage in a yard surrounded by a high wall, and there hung up. To the admiration of all of us who saw it, two 'Titlarks, no doubt its foster' parents, soon found it out, and fed it for some weeks with a worm every few minutes. I found the Pobin's nest once nearly in mid-winter, and once in the pocket of an old coat, hung up in a coachhouse, and another time saw one in a charity school full of village children. I have seen the Ringed Snake swim about actively in the water; and once, on a neighbouring chase, seeing a congregation of rery excited Chats and Larks, on reaching the spot witnessed a strange scene. A viper had swallowed a titlark, but at my approach, to effect its escape, it opened its hideous jaws and throat and disgorged the little dead bird. The Ring Ousel and Twite bred in our neighbourhood; the Brambling was seen only in the winter, with the Spinks. The common Linnet was called the Gorse Linnet, the true Blackcap the Flaxen Wren; so perhaps we may conclude that formerly, when flax was grown, the latter used it in the construction of its nest, bed-straw (Galium) being now substituted; the Flycatcher was called the Miller, perhaps from the mealy plumange of its young.

My little garden was filled with the Oxlip, the mossy Saxifrage, Orchids of several sorts, and such like. I knew a dell full of the latter, and once brought home a magnificent specimen of $O$. latifolia, like a pole over my shoulder. My first book was Piunock's 'Catechism of Botany,' which I bought and mastered whilst a schoolboy; my second, 'Rousseau's Letters,' by Martyn; both were very dear books to me, and I should like to have them again even now; I could swear to type, cuts, and paper.

My ichthyological researches, I fear, early took the 
piscatory form. When grown too ambitious to be contented with the Miller's-thumbs or Bull-heads, the Loaches or Beardies, the Pinks, and Nine-eyes of the brook, I aspired to a rod and line, and my first prize was not the greedy perch, but a fine trout of a pound or more. I had been essaying my skill in the deep elbow of a crystal brook, but, the mid-day sun being hot, I soon tired, and, throwing my rod down, I fell a dreaming amidst the wild chervil beneath the blooming thor's. When I awoke I could not see my float, and pulled out my line with a desperate swing, throwing into the air, and then into the long grass, the golden and speckled prize. I once lost fish, rod, and tackle altogether, whilst studying leeches and naiads, and only got them again by stripping. I was taught the difference between a Barbel and a Barbolt, a Beardie and a Groundling, or a Grayling and a Graining; for I had a relative who was luckless in business, but clever at anything else, and about the best fly-fisher in the land, who initiated me into the mysteries of his craft-including also palmers, spinners, drakes, stone and orl flies, and yellow Sallies; the mallard and golden plover were robbed of their feathers, and a red cock's hackle, or the rving of a dun-coloured hen, was duly estimated, besides unravelling the carpets to get bits of peculiarly coloured worsted. Yet too often the trout and grayling escaped me, more learned than dexterous in the gentle art. On one occasion, however, I caught about fifteen brace of fish ; but the mode was unsportsmanlike-creeping behind the bushes, and dibbling, as it is called, with the natural green drake or ephemera. On another occasion, in after life, this piscatory knowledge was of real service, for being, with a party of other English travellers, confined by stress of weather in an Alpine 
châlet, which afforded little to eat but dried fruit and bread, in the dusk of evening I saw beneath some water-falls a species of salmon-trout rising freely in the river; and, being up to the thing, I extemporised some artificial moths, from a grey feather or two, similar to those which were flying about, by means of which one of the party, who had a walking-stick fishrod, caught several brace, and added an acceptable dish to our scant breakfist.

However necessary scientific names may be to embody and record our knowledge, I was acquainted to some extent with objects of natural histrry without knowing their names; and, before aquaria were found out, had jars with aquatic beetles, spiders, crawfish, Spongilla, Plumatella, and Alcyonella; all the three last found at the margin of our canals adhering to the piers, and Alcyonella often hanging down in masses from dripping arches. I lad Hydræ green and grey, the former the rarest; and a friend once brought me the Apus. On one occasion a large water-beetle, the Dytiscus marginalis, was placed in the same vessel with a water-scorpion, the Nepa. The latter attacked the larger and stronger beetle, and eventually destroyed him by nipping off, first, one of his powerful swimming legs, and then the other; after which the monster was as much at its mercy as, it is said, one of our old wooden men-of-war would be with one of the modern iron-clad steamers. Those who keep aquaria soon find out that waterbeetles, even the large Dytisci above mentioned, are apt in the evening to leave the aquatic element, take wing, and may probably settle on some fair one's neck, should there be such in the drawing-room. To prevent accidents, a glass cover may be placed over the water-vivary at dusk. 
Time went on, and boyhood ripened into youth with all its aspirations, and so the distant horizon became daily a strong temptation. One morning a party of us set out for a walk of more than twenty miles, part of which was over moorland, bright with gorse and heath-how delightful ! - then through rocky woods still more entrancing! In a little valley of surpassing fertility, made so by a crystal stream, which a little higher up sprung from the gravelly earth, were the ruins of a Cistercian monastery,* then almost unknown, and now not often visited. At the entrance into the unroofed and windowless aula, upon a mound of emerald turf, we found a nice place of rest, where we determined to empty our satchels of their acceptable contents. Close at hand was the stream from which to drink. How glorious are these marsh marigolds, and see what a pretty beetle (Helodes phellandrii) nestles in every golden cup! Here are little shells too on the ivy of the crumbling walls, helices round and flat, nummy and chrysalis shells. None of us being of sufficient celebrity to have names in print, we can only say that we formed a trio. One made pretensions to antiquarian lore, explained the plan of the place, and the age of the walls; but, as is often the case with antiquaries, got imposed upon by the other two, respecting an old sandal which the latter picked up in the ruins, and introduced as a present just made to them by the tenant farmer, and as having belonged to the last of the abbots; it was for some time placed in his collection. But verily we poked out the skull of some great one from under the transept wall. We noticed the following plants, not seen 
before by us-the handsome Meador Geranium, the Orpine, the broad-leaved Bell-flower, Hemlock, the Wall-pellitory, and othess. A walk of two or three miles further, over fields and through lanes, led to another ruin, but of a different character; an old feudal fortress* perched on one of the red sandstone cliffs, which overhang the river Churnet, at that time consisting of but some crumbling walls, surrounding a grassy court, from which it was dizzy to look down on the river, winding in the deep valley beneath. Near the walls grew the Deadly Nightshade, and in the woods opposite the pretty Winter-green (Pyrola minor). Since then the noble owner adorned the site of the ancient castle with picturesque ecclesiastical and conventual buildings. The neighbouring gardens were, and are still, remarkable, from the indelible natural pictorial landscape. At the entrance is read, under a bust of their original projector, 'He made the desert smile;' and verily a wild moorland valley, rugged rocks, and barren commons, have been converted into an enchanting, though fanciful, scene.

Thence the following day we bent our steps down the river to its junction with the Dove. We fished, but gave it up in disgust with either the fisl, our tackle, or ourselves, and marched on to one of those ancient fortressest in which once the unfortunate Scottish queen was incarcerated. Not to be forgotten was the calm look of its towers, and the wooded hill on which they stand, as we approached them on a sweet evening; they seemed themselves in a silent dream of ancient times. There stood an abbey also hard by, built by a proud Ferrers, whose body was interred within, wrapped up in one of the hides from

* Alveton or Alton Towers.

$\uparrow$ Tutbury. 
his own wild oxen; and the doorway of the church belonging to it surpasses probably the celebrated one at Rochester in its Anglo-Norman carving. Some of the castle buildings are as old as 'time-honoured Lancaster,' who held plaisance and revelry here, and Robin Hood is said on one occasion to have been an unbidden guest; other parts are more modern. It may be made out from the public records that Mary occupied that part of the building, of which a portion is still standing, to the left of the great gate. In such spots poetry or romance or fiction seems in place; surely here is the scene for a novel or tragedyMary Stuart, the finale to be at Fotheringay! 'That matchless queen!' to begin ; but no, when here she was not perfect beauty, but rheumatic; and your rheum and poetry do not go well together. She was indeed, as the aforesaid documents say, removed to Buxton baths on this account, where, on her last visit, she is said to have composed a pathetic Latin couplet, and our only poetical attempt was to translate it:-

\section{Buxtona, que calide celcbrabere nomine Tympha, Forte mili posthac non adeunde, vale.}

Buxton, farewell! thy far-famed waters ferrent flow, But I perchance no more their healing powers shall know!

Poetry was voted nonsense, and fly-throwing almost as great foolery; even the pencil and the picturesque were slighted. We aspired to science, and were becoming as self-sufficient as other eminent botanists before us-Linnæus or Sir J. E. Sinith, for instance. We found several more novelties in this line, Lactuca virosa, Henbane, and the Dwarf Elder, all poisonous plants, but also several more delectable, the Clary (Salvia) the Gromwell (Lithospermum officinale), and others. 
The trip just recorded was but our 'little go.' The time at length arrived when, released from lecturers, examiners, et hoc genus omne, and possessed likewise of a little cash, that is, of all that the worthy professors had left us (for it is a maxim with thein that the head cannot be filled unless the pocket is emptied), we made our first scientific excursion, commencing it about the centre of England, and proceeding through the Peak, Craven, and the Lake district; my companions again two in number, as zealous and learned as myself in natural history-zoologists, botanists, mineralogists, geologists, and what not? V-C was inventive and fond of minute research; he shortly afterwards planned a microscope, one of Ross's earliest productions, which is still figured in books of note, and which, before the introduction of the present compound instruments, stood high; besides publishing papers in the 'Linnæan Transactions,' \&c. Qafterwards rose to eminence, and became professor at one of our principal institutions. We had spent some pleasant evenings together at the mansion of a gentleman, well known in those days as a Mæcenas in such matters, but also indeed, a little later, as a great patron of beggars. We seriously debated, before starting, whether we should furnish ourselves with tent, \&c., for our travels, but finally concluded to journey as civilised men, content with botany boxes, portable press, insect nets, phials of spirit and pillboxes, hammer, chisel, and bag, and, lastly, a barometer and thermometer of the contrivance of one of my friends; the former, however, generally getting deranged when we wanted to make an observation.

It was on the evening of the last day of May when, after a killing walk, we entered the town of Derby. Large was the measure of coffee swallowed to make 
up for the transpiration of the body during a hot day's walk. The following morning saw us at the entrance of that charming spot Dovedale, then very little frequented. Our botanical acquisitions were the Green Hellebore, the impatient Lady's-smock (Cardamine impatiens), the mossy Saxifrage, the vernal Potentilla, the Nottingham Catchily, and several other plants. The Bird-cherry was in full bloom, of fragrant but sickly smell. We found on the rocks a variety of mosses, and others in the river.* From the leaves of Fontinalis squamosa, very regularly disposed, we found that the larva of some Phryganea formed a curious aquatic dwelling. There was also in the Dove Lemania fuviatilis, a large dark-coloured alga, peculiar for its unpleasant taste and smell, the curious Nostoc pruniformis, and a large dark olive species of Batrachospermun, a foot or more in length. Cyathwa regia also grew on the rocks, and the Spindle-tree (Euonymus) and buckthorn (Rhamnis catharticus) were also common, the former remarkable for its small green fotid flowers, and its crimson capsules contaiuing orange-coloured seeds. We distinguished the minute Achatina shell, and caught, amongst other insects, specimens of the groen-winged Thecla querci, the bronzed forester, the Brimstone Butterfly, Fritillaries (Euphrosyne and Selene), and the lesser Tigermoth. We noticed in the high part of the dale-a part, by the bye, very rarely visited, but different from, and wilder than, the more frequented lower portiona party engaged in catching trout by hand. Four men in a line entered the stream and followed it up, quietly groping' with their hands under every stone;

* Cinclidotus, Fontinalis squamosa, Muhlenberg's Funaria, a new 'Tortula (T. lrvipila), Neckera, Dultonia, Encalypta rulgaris, Bartramia arcuata, Orthotrichum anomalum, and Lyellii, and mumerous Hypna. 
from some want of apprehension the trout and grayling allowed themselves to be seized in a very wholesale manncr. They liave a plan, too, of trapping the cray-fish, by sinking a faggot where they frequent; on taking it out of the river it will be found that many of the little crustacea have crept into it, especially if baited.

So pleasantly time passed that we got benighted, and aiso caught in a storm, which transformed the beautiful spot into a dreary enough scene. We hastened to a neighbouring village, and were cordially received by a comely dame, and regaled with ham and eggs, and fresh ale, mellow as an apple. Youth and exercise and good spirits are more efficacious for an appetite than sauce or bitters. The folks stared at us as we placed our piants in paper, and thought, no doubt, it was a queer way of getting a living-the use, physic of course. The next morning we were up almost with the sum, and a stiff walk bronght us down to another beautiful valley, that of the Manyfold, at a lighl rock or tor, where another river, making its exit from a side valley, forms a junction. It was a charming scene for a painter-a high precipice of limestone, wooded dale, fertile mead, rustic bridge, and old cottage with curling smoke, standing in the otherwise solitary spot. In a valley down which we had passed, there were acres of Lily-of-the-Valley, and the Mezereum also grew. A fissure in the rock tempted our curiosity, and, getting candles, we pemetrated, sometimes crawling on all fours, sometimes more reptile-like still, a long way into it, and, after several turns, we at length stood in a lofty fissure, far in the interior of the rock, at least far enough by the road we entered, where probably no one had ever been before, and where our initials will be some day 
discovered by some more assiduous cavern explorers. We picked up some bones of deer and of the roe, and there were others, smaller, lying about; we also produced a great sensation amongst the daws, bats, and hawks, inhabiting the rock. We were glad at last to regain the light of a glorious morning, which, alas! revealed to us that we had scrionsly deteriorated our clothes with clay and tallow, so that we had to devise various modes of repolishing them.

The rocks in this valley abound with limestone plants - the beautiful Vicia sylvatica (not then out, however); the fragrant Gymnadenia; Jacob's-ladder (Polemonium ccoruleum), pretty with its dark-blue flowers and their yellow anthers, but sickly in smell; the Alpine Rubus; Melica nutans, a rare grass; the Kidney-retch (Antliyllis vilnerarici); the Salad-burnet (Poterium), and mmerous ferns, as the Ceterach and Aspidium aculeatum and angulare.* We got some really splendid specimens of iridescent copper pyrites, including stalactical and arsenical varieties, at a mine a few miles higher up the valley. With respect to the cottage, mentioned above, there is a melancholy history. The woman who lived in it had been trvice married, and lost both lusbands through the swelling of the river, which may be dry and subterranean one hour, and the next rapid and dangerous. The first husband, in the excited stage of a ferer, got up while she was gone for his medicine, and was drowned; and the second met with the same fite returning from market. We crossed by the aid of an accommodating old horse that was grazing

* We need not gire the English names of ferns, for their fanciers nowa-days, especially ludies, have their most approved scientific appeilatives quite glib. 
near, and who seemed to take to the job quite naturally. We noticed the little fish called the Pride in the river.

By a short cut we got to a noted cavern, bearing the name of Thor, the terrible Scandinavian god, thougli a friend says it should be tor-house or cavern, instead of Thor's. It is the latter, however, both oral and written, whatever the derivation. The thicket below is called Hob's-hurst, the fiend's grove; the bridge above has also an unaccountable name, Darfur-may it not be the Celtic word signifying termination, as the river sinks into the earth at the spot? 'The walk was heavy, and we sat down on the tup of the hill to rest and to survey the beautiful scenehills, rocks, and winding streams, in which were some cattle cooling themselves, the only living things in sight. The cavern yawned nobly, if yawning can ever be considered noble, high abore the river, with a fine natural arch in the firce of the limestone rock. The barometer at the bed of the stream showed an altitude of 562 feet; the top of the rock 357 feet higher. Saxifrages of three or four species, the Speedwell-leaved Whitlow-grass (Draba muralis), the Hairy Wall-cress (Turritis hirsuta), and the least Mountain Bedstraw (Galium pusillum) grew around; also the curious Lathrea squamaria, parasitical on the hazel, but now in fruit, besides otlier plants before mentioned. I afterwards got a countryman to dig a litile in the floor of this cavern. Some bones of deer were tound, but nothing more. In the year 1864, however, the Midland Scientific Association made some extensive explorations, finding numerous late British, RomanoBritish, and Saxon antiquities, curious whistles, made from the antlers of stags, a comb and pins of bone or stag's horn, a Romais fibula and a wheel in 
bronze, the latter apparently for spimning; also weapons in iron, and some human bones, but no flints, or objects of such high antiquity. One or two rocks higher up the river were extremely productive in plants, ${ }^{*}$ and numerous fine lichenst also occurred, as well as insects and molluscs. One rock was indeerl a microcosm for a naturalist. The cliffs too abound in fossils in this neighbourhood, and other caverns and fissures are probably worth the exploration of the geologist and ethnologist. A countryman told us that he had seen smoke issue from one of these caverns, and the philosophers laughed, but on reflection the circumstance seems not unlikely, as it might emit warmer air saturated with moisture, which would become visible in the colder external atmosphere. Possibly the spot is also near the fault passing through Buxton; and indeed further up on the same line is a smoking spring, called the warm well, though now covered over and forgotten. Following up the valley, we passed some remarkably contorted strata of shale and limestone, and came to a once celebrated copper-mine, Ecton, where we found carbonate of copper, apparently formed in the workings, some yellow fluor, and very large crystals of dog-tooth spar, also smaller ones of quartz. The crystals of spar have others of sulphuret of copper disseminated through them; these, as well as other specimens found here, called bacon-stones, vulgo, formed of layers of galena, barytes and calc-spar, seem to prove the origin of mineral deposits to be in such cases from the action of water

* An Allium, Viola hirta, Inutchinsia, Hippocrepis comosa, the Alpine currant, and Graphalium dioicum.

$\uparrow$ Endocarpon miniata, Solorina saceata, Collemas and Nostocs; also the rather rare liverwort Marehatntia hemisphxrica. 
principally. The temperature of the Ecton mine at 1,500 feet was said by the manager to be only $53^{\circ}$ Fahr. We noticed Carduns lieterophyllus or the melancholy Plumed Thistle, and the Genista anglica, or needle Greenwood, to grow on the limestone shale.

But now the sun approaching the high western hills, as well as considerable futigue, warned us to make for quarters. We crossed the Dove at a sweet spot, Pike Pool, mentioned by old Tzaak Walton in the 'Complete Angler,' passing' by Beresford, the home he of his son-in-litw, Cotton, at that time almost a ruin. We had a little time to survey it, as well as the noted fishing-house, with an old ruin, and a cavern, where it is said the poetical spendthrift and rake hid from his creditors. A peaked rock of limestone rises out of a deep pool of the river, where the path crosses it by a wooden bridge. One of the party had a bath in this pool, cool and clear. There were some fine Beamtrees (Pyrus aria) in the valley. Passing through a grove on the hill-side we soon got quarters at the village close at hand.

Next day re pursued our way up a glen towards Matlock, where we picked a rather rare grass, Aira cristata, on the exposed rocks. On the hills was the dainty Mountain Violet (Viola grandiflora) of several colours, which perhaps should be tried as a garden pansy; there was also the vernal Sandwort amongst the refuse of lead mines, a small but pretty flower when expanded in the sun, and nowhere so pretty as in Derbyshire. We had a glance at an interesting druidical circle, Arbor Low, and the survey of it put us upon antiquarian inquiries. Seeing some men in a quarry, we'asker if they ever found any antiquities. 'Any what, Sur?' 'Any antiquities-or curiosities?' 'Oh, yoi, Sur, plenty o' them o' th' soid o' yonder low.' 
'They dunna mean them,' put in another. 'Any curiosities - bits of white flint, beads or coins?' 'Oh, yoi, but it inna the toim for them.' Seeing that they could not understand that we wanted anything more than mushrooms, crabs, or nuts, we gave antiquities up; yet flint chippings are here often found, and sometimes neatly worked, in almost any field, though no flint-stone in situ naturce is ever seen in the district. But we were doomed to have another interview with a couple of these boors, for as we crossed a wide valley we saw two of them on the other side running and shouting vociferously for us to stop. A case of life and death, thought we; and having lancets in our pockets, and being moreover not averse to make an honest penny, we turned back a good step out of the road to speak to them. To our annoyance, they demanded if we had a good whittle to sell; and upon our indignantly spurning them, they inquired whether we were not the hardware men from sheffield! The road through the Via Gellia, so called, was lined with the lily of the valley (Convallaria majalis) in full bloom.

We hoped to have made a collection of minerals at Matlock, but the Museum keepers were not pleasant tradesmen in those days, and we did better with some miners, from whom we procured the pretty carbonate and phosphate of lead: we got specimens of toalstone above the baths. The Alpine Shepherd's-purse (Thlaspi alpestre) was a common weed, as was also Cardamine impatiens, and we also picked the Spurgelaurel, and the Hawlsweed ox-tongue (Picris); but what we sought for at first in vain were the Fly and Bee Ophrys, the former fast passing over; however, at length we found a lad, half rogue, half idiot, who took us to where the fleys and beys, as he called them. 
were found, as well as varieties of Orchis pyramidalis. We walked towards Crich, but a few inineral specimens from a mine by the way, and a rare grass, the Pinnate Brome, were the only valuables we found, with the exception of mosses, of which we picked many.* But here we were to part with our cryptogamist; duty called him arvay, and I only saw him again, for one evening. Returning to Matlock, I and my other friend ascended Masson and the High Tor, but were turned back on the last by a churlish farmer, pitchfork in land-and irascible farmers with such weapons look dangerous. In his heart we attempted in vain to enkindle an admiration of the sciences, and comtenance for their votaries. In vain we opened our boxes before him, told him we were only in search of simples for physic; the clod of a fellow threatened us with the Lover's-leap, which as we had no love for, we gave up orchis hunting, and proceeded to descend in the usual way. We rent into a carern below the rock, and explored another, the Cumberland cavern; the latter very extensive, and having some huge loose and displaced masses of limestone in its interior, though otherwise uninteresting. A vapour issues from it in winter. As is well linown, the Matlock water's feel tepid even in warn weather, and also smoke in cold, having the temperature of $68^{\circ}$, as has the water in the cavern. These waters petrify, and have deposited the great formation of socalled tufi in the valley. A dark-groen gelatinousfeeling conferva grows where they issue forth, and there were specimens of the beautiful Chamoleon larva (Strationys) with it.

* Encalyptar streptocarpa, TTeissia cirrata, Didymodon longirostris, Dicranum flagellare, Trichostomum fasciculare and polyphyllum, Bryum rostratun and marinatum, Anomodon viticulosum, \&e. 
Somewhat crestfallen with our rebuff, we pushed on to Haddon Hall, the view of which, as we approached it, was very striking. We went over its spacious hall, chapel, and apartments, its courts, its terraced and balustraded gardens, and examined its oriels, tapestry and antique furniture, and also listened to the tales of the cicerone. We then crossed over some moors, and through some woods to Chatsworth, the palace of the Peak, but to our shame passed it without a visit. But Paxton had not then made the gardens what they are now. V- had previously found the little heart-leaved Twayblade (Listera cordata), and also Aceras anthropophora, on these moors. We afterwards came to Middletorn Dale, a place not prolific in new plants, but the rocks were grand in appearance from their lofty and castellated form. Hypnum ruscifolium in fruit grew in the rivulet, and we picked the Lesser Meadow-rue (Thalictrum minus), and the drooping Silene. A valley leads from the dale up to Eyam, with some curious rocks at the summit, which we concluded to be the place called Cucklett church, where the devoted Monpessan assembled his flock during the plague. A friend, Dr. H_-, had found Stellaria nemorum here, but we looked for it in vain; however; the Dame's Violet (Hesperis matronalis) grew wild. We went to look at the Runic cross in the churchyard, and to the graves of those who died in the pestilence, introdnced into this sequestered place, it is said, in a package of woollen goods sent from London. There is a druidical circle in the neighbourhood and several barrows.

Castleton is an interesting locality for the naturalist. We visited the Speedwell mine, which is worth the trouble; but the noise of the shot which the leader 
fired was anything but congenial to the nerve of hearing. A boat conveys the traveller for some distance along the subterranean stream, at the end of which the water falls into a deep abyss. A rocket, it is said, may be here fired upwards, and attain the usual height; we only threw some stones downwards, which reverberated long and hollow in the dismal depth. We made some very scientific observations (!) on the temperatures of the water in the different mines and caverns, all however about $46^{\circ} \mathrm{Fahr}$. The entrance to the Peak cavern is fine, at the bottom of a huge cleft in the mountain, immediately under the castle walls, which are seen at a great height above. With respect to the cave itself, we cannot attempt to rival the local histories in their description; neither in that of the castle. We walked up the Winnats, one of the wildest valleys in Derbyshire, and found on the surface good specimens of purple fiuor or blue-John: this spar becomes very red by the treatment of heat. Of the elastic bitumen peculiar to Castleton, and found in the blue-John mine, we got a lump the size of a child's head for a shilling, and also fine crystals of fluor equally cheap; the dealer here appearing a more reasonable fellow than those at Matlock.*

About the castle rocks were several good plants, $\uparrow$ one a new or imperfectly described Hawkweed (Hioracium), then in flower, probably the same as the one mentioned in the 'Botanists' Guide' as distinct from every other British species, but most nearly allied to H. murorum.

* Te beliere he was a well-known and eminent local mineralogist and geologist.

$\uparrow$ The scurvy-grass, Cochlearia officinalis; Thalictrum minus; Sedum upestre. 
We cannot say much of the road from Castleton to Buxton; it is carried through a barren tract of the limestone shale, and, in truth, we got a vehicle for the stage, but pulled up and descended into the Odin mine; we passed Mam Tor, the shivering mountain; had a look at the ebbing and flowing well, and at Eldon Hole; getting to Buxton in the evening. Next morning we found some botanical prizes a little way down the beautiful valley of the Wye, the Globe flower and others.* Several of them were found up a dell to the right, as one descends the valley, about a mile from Buxton. On the hill above, a circular fortification, with some barrows, is to be seen, and, a little further on, a Roman road may be traced across the fields and under the stone fences to the town. At the cottages hereabouts may be seen great masses of limestone, so curiously shaped that they are often placed before the houses as curiosities. Upon inquiry, we found that they were commonly met with beneath the surface. They are of the same appearance as we may have noticed in the low rocks on the margin of the sea, when the shore is limestone. Geologists must settle whether they are due to the same cause, or to the solvent action of fresh water. On the road to Poole's Hole we picked Cystopteris fragilis, and London Pride, the latter no doubt originally introduced. This cavern is well worth a visit. It has wonderful chambers, enormous stalactites and stalagmites, and a river running on its floor. It is now made a show-place. When we visited it I think the road either inwards or outwards briclged over the other, which is now not the case. Bones

* Polypodium calcarcum; the clustered Bell-flowcr (Campanula glomerata); the bloody Cranc's-bill (Geranium sanguineum); the twistpod Draba; and the rock Hutchinsia. 
are to be found amongst the sand and rounded gravel on the floor; what we picked up were those of ruminants, sheep or cieer, but some of pachyderms and carnivora are shown, the exact species of which we liardly like to fix, being no adepts, and Derbyshire guides being, like guides elsewhere, not free from roguery. Roman and other remains pertaining to man have also been found. We picked up a few fossils a little to the south of Buxton, where they seemed most plentiful; * also the purplish Buxton diamonds, very perfect in their quartz form. + We followed a rivulet, one of the springs of the Dove, to the top of Axeedge: on its moist banks the common Butterwort (Pinguicula) and the Sun-dew (Drosera) grew, both interesting from their singular appearance, at least when found for the first time; and in the rivulet itself was a beautiful Jungermannia. On the mountain we found the Cloudberry, the rare and curious mosses Splacinum sphcericum and Andrea rupestre, and Lycopodium clavatum and selago. There is a quarry of flaggy grit near the summit, and various thinnish beds of coal and shale; in the latter are to be found characteristic fossils. $\neq$ The district is bleak. The hostelry where we put up was called the Cat and the Fiddle. Miller's, Cresswell, and Monsall dales

* Uniralres, spirifers, terebratuli, orthoceratites, goniatites, and fragments of trilobites. Trenty yenrs back, we had distinguished and collected about forty species. A friend, a rillage clerk and schoolmaster in this retired district, has now collected about seren hundred species and rarieties of zoophytes, molluses, radiates, trilohites and fish fragments. ITe has, howerer, incurred the penalty of being considered an atheist by his reverend and primitiro pastor, because he denies that they are the remains of Noah s deluge.

$\uparrow$ The beautiful ferro-barytie stalactite is said to be found principally at Moneyash.

† Linguln, goniatites, and ariculopecten, often eharacteristic of certain beds in tho lower coal measures. 
beautiful spots, are now easily attained by a few minutes' ride from Buxton or Matlock.

We next made for Chapel-in-the-Frith, where my remaining companion was to mount the coach and leare me. Both these companions were stronger and more careful men than myself, and worthy, if any one is, to live and adorn society; and yet both were called away a few years afterwards for ever. I trudged on, feeling like a truant, and disconsolate enough, hardly knowing where I was going, or what I was in search of; so much is companionship in travel! I passed through Glossop to Woodhead, in those days a wild and secluded spot. Here I passed the night, and next day explored the commons and swamps opposite the inn, and ascended some of the streams which dashed from the opposite hills over their stair-like rocks, but found little except mosses and Jungermannix. I determined to extend my walk northwards, and make for the coast, certainly south of the border. I passed by Holme-moss, through Huddersfield, respecting which place (though I would wish to say something of every rendezvous) I can record nothing. At Halifax, however, I may say that the guillotine was invented (vide Camden for a picture of it); whoever stole to the value of thirteen-pence halfpenny within the boundaries of Hardwick Forest, lost his head. Keighley is situated amongst wild moors, but is itself one of the hives of Yorkshire. The road continued skirting the Millstone Grit hills composing the backbone of England to Skipton, where the castle and church are both worth inspection, the former the ancient fastness of the Cliffords, some of whom were restless and bloody enough when living, but finally in the church they did find rest. There is a yew-tree remarkable for its size and 
antiquity in the court of the castle. The church windows at the east end are of the decorated style; elsewhere perpendicular and later. At Settle the grit and shale formation is left, and we get upon the limestone, and consequently the scenery becomes finer. Near hele I met with (for the first time) the Bird's-eye Primrose in beautiful flower, and rarying: in tint, its pretty eye so cheering to the traveller; it was abundant as I proceeded. Hattermire, Goredale Scar, and Malham Cove and Tarn, lie to the east of Settle, interesting places, particularly to the naturalist. To reach them, one must turn off the road to the right between Skipton and Settle. We shall then arrive at Kirkby Malham and Malham village, lying in a retired and pleasant valley, the former having an ancient church; a short walk from the latter leads to Goredale Scar, a wild and picturesque scene. Following up a stream along a narrow valley, we notice the water in part rising up from fissures half concealed in the rocky or grassy level; but, proceeding, the valley closes in, the rocks overhang, and a conious mountain torrent dashes down them, making two or three turns or stages, and at one point perforating a passage through the limestone rock. I climbed up by the side of the torrent, and noticed a few plants, Cochlearia, Thalictrum, and some others. At the top, one comes upon the open hills, with a dale to the right, and in it I noticed a ring-ousel, having apparently a nest; there were also other novelties in the bird way on the unfrequented moor. The Mountain Violet was frequent on the exposed pasture. Malham Tarn was visible, but it seemed a long distance off, and it did not look sufficiently picturesque to tempt me on, so I turned to the left in search of the Cove. The limestone on the tops of the hills, 
and especially above the Cove, presented a level upper surface, with many perpendicular fissures or gutters produced by weathering, washing by rain, or some such action; there were also some rounded erratic blocks and accumulations of rounded gravel and boulders. The Cove presents a high perpendicular wall of limestone curved into a concave semicircle, with a river gushing out from the bottom. Asplenium viride, Circcea alpina, Gnaphalium dioicum, Pyrus aria, Draba muralis, Thlaspi alpestre, and Arenaria verna were picked by me. A walk over the wild moors, passing at one point a waterfall tumbling over the Millstone Grit and Yoredale rocks, leads down to Settle, over which pleasant place hangs a bold rock of limestone. There is an ebbing and flowing well near the town at Giggleswick. I got a lift on the coach from Settle to Clapham, seven or eight miles. Here I engaged a lad as guide to the wonders of Ingleborough, and first to Ingleborough Cave through a gentleman's grounds. Since this visit, however, the cavern, having been further explored and made available, is well secured at the mouth by an iron gate, and only opened by half-acrown. In the walk I picked the Globe flower, the Columbine, the Wood Crane's-bill, Cnicus heterophyllus, Lastraca rigida, and Primula farinosa. A little brook runs out of the cavern, but I should suppose that it was formed by the larger river which now emerges within a stone's-throw at a lower level. The stalagmites and stalactites are of various forms and truly curious-pendents, pillars, fleeces, bosses, and what not? Sometimes a sheet of carbonate of lime is spread out on the surface of the little pools. We went next to a hole or gill (Gaping Gill Hole), somerrhere on the south side of the hill, in the jaws 
of which a stream buries itself, to emerge afterwards at Ingleborough Cave. There were many small trout in the stream. We then began to climb the mountain, 2,361 feet high, but a mist came on, and my friend got bewildered, and neither coaxing nor a shilling would pacify his nerves. I continued to ascend alone, and was shortly on a plateau at the summit, where I walked about for some time, but could see only a few yards before me; at last, however, I stumbled upon some great object looming in the fog, which proved to be a tower, and I noticed traces of ancient encampments and ancient hut sites. I now wished to descend, but, having no compass, hardly knew which way to take; in fact on several sides I came to a sort of sunk fence of rock; fortunately, however, I took the side I should have done, and when I emerged from the misty cap upon the curiously cloven bed of limestone, a beautiful view met my sight: in the distance was Whernside, twentythree feet higher than Ingleborough, whilst nearer was a pretty valley lying beneath me, at one part strewed with rocks, but lower down to the left dotted with clumps of trees, and the white tenements of Chapel-le-dale.

The plants of Ingleborough are numerous, besides many rare mosses, which I assiduously looked for.* Wethercoat cavern lies above the chapel, and I there also picked a few rare plants, as Actoca spicata or Baneberry, in flower and abundant under the bushes, Stellaria nemorum, Allium carinatum, Mecanopsis and

- The flowering plants-Seclum villosum, Rhodiola, saxifrages (S. oppositifolia, stellaris, aizoides), Salix herbacea, Hieracium villosum, Gnaphalium dioicum, \&c. The cryptogamic plants-Lastrea rigicla. Mosses -Andræa, Splaclnum, Dicranuin flexuosum, Encalypta ciliata, Bartramia arcuata, Anomadon curtipendulum, Triclostomum aciculare and canescens. 
Saxifraga geum, the latter no doubt introduced. The place is not a cavern exactly, but rather a cascade, with a huge stone jammed in above, and the water swallowed up below. There are some other places of the sort (water-swallows) at hand, called Hurtlepot and Ginglepot, and a real cavern higher up in the valley. From Ingleton I started afresh next day, first searching the neighbourhood, principally with the hope of finding the Lady's-slipper (Cypripedium), but in vain ; yet there were other good plants, the narrow-leaved Helleborine (Epipactis ensifolia) and Solomon's-seal (Convallaria polygonatum). I visited a cavern called Yordas, having numerous stalactites, containing also a remarkable chamber, in which is a cascade. In Kingsdale Beck the river fell finely over some rocks at a place called, I think, Thornton Force, making a respectable cascade, and I now, being left to my own devices, transferred the view to my sketch-book, a capital way of impressing a scene upon the memory, even should the picture itself be lost. Further on the road to Dent was a second cascade, a sheet of water falling from amongst the foliage at the top of a rock into a pool beneath, forming another choice bit of scenery.

This is a land of fountains; the sources or large feeders of the Ribble and the Wharfe are but a few miles north-east of Ingleborough, the former flowing into the Irish Sea, and the latter into the German Ocean; the Aire, too, rises near Malham, flowing southeast. Then, trending to the west, are other rivers arising here; the Eden, the Dee, the Lune, and the Wenning. A friend picked the rare and beautiful moss Hypnum cristacastrensis in Dent Dale; and on Whernside, on which I made a détour, grew a small Cochlearia, and other plants usually met with on the 
seaside, as Thrift, and the Sea-campion; at its extremity are some small tarns. I noticed the Wood Crane's-bill (Geranium sylvaticum) in a meadow as I approached Sedberg, where I was detained by rain; it was the market-day, and from the window of the inn I sketched the market-place and cross, or rather pillar, the buyers and sellers, who appeared thorough-bred Yorkshire, and, in the background, the ancient parapeted church. I have a bad ear for languages, and could hardly make out the Craven dialect, but had no reason to complain of my fare: for breakfast, generally trout, potted or fresh; and for tea-dinner, tender and sweet Yorkshire or Cumberland ham, with fresh eggs-such savoury meats as one's 'soul loveth.' Next.I entered Westmoreland, traversing some wide commons with a sandy coast (Morecambe Bay) on the distant west. I passed a little tarn, and picked Anchusa sempervirens, or evergreen Alkanet, on the roadside. I stayed but a short time at Kendal, slighting too much its notabilia, church, castle situated on a verdant hill, and its traces of the ancient masters of the world, being in a hurry to make Winandermere; the town, it may be mentioned, however, is noted for two comforting articles, wool and Quakers, to say nothing of 'Kendal Green.' I got to Bowless in the evening. On the common, Brent Fell, above the village, were the Dwarf Juniper ( $J$.nanus), the Meadow Bedstraw (Galium boreale) and other plants. A light-coloured owl was hunting over the long grass of a meadow, more quietly than hunters commonly follow their trade.

I fear the descriptive portion of the remainder of the journey would be better resigned to lakists and guide-books. In the morning I rambled about, and 
skirted the beautiful lake to Lowood, whence is a fine view of the head of the water; then through a wood and over Troutbeck Bridge, at the opening of the valley of the same name, to Ambleside, around which village there is much to interest; I picked the Columbine in the course of the walk, and at Stock-gill Force the Yellow Balsam (Impatiens noli-me-íangere). I also picked Veronica montana, Polypodium phegopteris, and Circcea alpina. At Rydal there was another view, fit for a picture, with some bold rocky hills to the right, called Dove, or Doe crags ; these I climbed and rambled about on the high ground called Fairfield: the little lakes lay in great beauty below. I gathered Saxifraga stellaris and aizoides, and some rare mosses,* but missed other plants which grow here.t I then passed the water-shed between Grasmere and Thirlemere; the latter little lake was wild enough, and the landscape was entered into the sketch-book, being generally bare, and an approach to the Alpine. The inn at Wythburn, however, is a pretty spot, on the left of the road, at the foot of Helvelyn, and here was my dormitory for the night. This side of the mountain is tame in comparison with the other; on it are to be found some decidedly Alpine plants. $\ddagger$ St. John's Dale, further on, affords a picturesque view; and Derwentwater, from near Keswick, is a well-known one. I walked through the former to Threlkeld, and *Andræen Rothii, Pterngonium, Anomodon curtipendulum, Anictangium
cilintum, Grimmiæ, and others.

$\uparrow$ Silene aciulis, Hioracium dubium, \&c.

† Oxyria reniformis, Saxifraga niralis, Cerastium alpinum, Sileno acaulis, Alchemilla alpina; also Saussurea and Rhodiola. The Alchemilla grows by the roadside; also the rock parsley (Pt. crispa) in profusion. Poa cæesia, Carex atrata, Lychnis alpina, and Sagina Linnex have lattcrly been found in the neighbouring districts; also Asplenium septentrionalc and Woodsia ilrensis. 
so to Keswick. An Epipactis, but not in flower (E. latifolia?), Salix pentandra, and other plants, occurred by the roadside; and near Keswick, on a somewhat elevated spot, is a druidical circle. The watercourse was full of rounded blocks of red granite, porphyry, \&c. At the last town I stajed two or three hours, and risited the museum, apparently a private collection, and certainly a curious medley of the interesting and absurd-Roman antiquities, Cumberlanu minerals, coal-fossils with outrageous labels, \&c. Amongst other things is a set of stones, capable of producing very pleasant music when struck by a musician. There is, too, a large model of the district to be seen. I afterwards ascended Skiddaw, mastering the mountain by following up a stream from its flank on the right of the road. Saxifrages were abundant about the upper part of the rivulet, and higher up grew the Creeping Alpine Willow (Salix herbacea) and some mosses-Trichostomum poliphyllum and lanuginosum and Polytrichum hercynicum, the first two entirely covering the ground in places. I wandered about on the summis; to my right was Saddleback, separated from me by what is called Skiddaw Forest, but without a tree; in the distance to the North were Solway Firth and the hills of Scotland; far in the west the sea, with the Isle of Man periectly defined, and above it, dimly seen, the Irish coast; southwards were crags and fells, pikes and stiles, without end; also Derwentwater and Bassenthwaite at my feet. I gathered tufts of the rare Grimmia Doniana, the only plant which I saw growing on the schist of the cairn on the summit. I got specimens of darkish schist with chiastolite from the eastern side. The Skiddaw slate is the oldest of the schists of the Lake district 
except the mica and hornblende schists, and was thought at this date to be non-fossiliferous. This is found now not to be the case, as it contains many species of graptolite and allied forms, bryozoa, orthoceras, annelide markings and tubes, algæ and crustacea.* One piece given me appears to have obscure markings of Oldhamia (?). It is considered, but not without doubt, to be of the same geological horizon as the Llandeilo flags. The fossils may be picked up without much searching from the screes or heaps of fallen fragments. Barff, Outerside, and Moorhouse are good localities. The middle slate series (Caradoc) of greenish grey, or sometimes of reddish and brecciated rocks, which succeeds south-east of a line drawn through Keswick and Egremont, is little fossiliferous, consisting in reality mostly of beds of a metamorphosed volcanic nature; but such is not the case with some of the groups of the third or upper series, having near the basis the stratum called Coniston limestone. This last, however, is not worked, but it crops out in a line in the same north-east and south-west direction through the heads of Coniston and Winandermere lakes, and dips south-east, and is a band rich in fossils-orthis, corals, and trilobites. The slates have granite, gneiss, sienite, porphyries, mica-schist, or hornblende slate or 'whintin' lying below, or in other cases injected upwards, and changing the texture of the slates in contact with the beds or dykes. The granite, porphyry, and other igneous rocks or beds are said by Mr. Phillips to vary curiously as to character in each of the three areas; though lower, they must be of more recent consolidation than the rocks through which they protrude.

* There are, howerer, but slight traces of organic remains in the chiastolite variety. 
The dottrel, it has been satisfactorily made out, breeds on Skiddaw and on one or two of the other mountains.*

The evening was beautiful, the week was closing, and with it this little tour ; the labourer was wending homewards, and the traveller doubly felt that he was a vagrant. I was soon to take leave of mountains and natural history, so I feared. I descended pensively towards Bassenthwaite, and pursued my way along its margin, sleeping at Barff ; and then, on the next day, passed through Cockermouth ; with that feeling, partly of anticipation, partly of melancholy, which many may remember to have experienced when necessitated to begin the struggle of life. I found spirit, however, to taike a sketch of the castle firom the bed of the river beneath its walls, and afterwards made the shore and slowly followed my way, in the afternoon of a beautiful Sabbath, to Whitehaven, interested with one or two sea-side villages which I passed, and delighted with what I could notice of marine zoology, star-fish, sea-weeds, and other rejectamenta of the sea. $\dagger$ At Whitehaven the coal is worked deep under the sea; I had noticed it cropping out, as before mentioned, on Axe-edge, 1,600 or 1,700 feet above its level.

The next aftermoon there was a steamer for Liverpool, and I took a passage. As we were steaming out, a fat man came up in a boat with several rowers,

* Mr. Irarkness says the following minerals may be obtained in the district:-.It Red-gill, caledonite; at Carroek-fell, wulfram, selieelite, apatite, telluric bismuth, molylulena-glance; at Calbeck-fells, phosphate of lead, arsenio-phosphates, sulphates and cupreous sulphate of lead, rarliated malachite, brochantite, and other minerals.

+ An entomological aequaintanee took Cieindela hybrida, the roodwhite, the brimstone, the painted-lady, and the purplo-hair-streak butterflies, as well as the cak egrer and the cinnabar moths, in this district. 
and attempted to board us, but there was more difficulty in getting him in than was expected, and an effort was made to pass a rope round him. He hung for some time over the side of the steamer, when the impatient captain gave order's for the vessel to go on, and the poor fellow fell into the sea. We saw him drifted along for a mile or so, floating admirably on his back with his tub of an abdomen upwards, and fortunately a boat which had shot across took him in, to our great delight, and put an end to our execrations of the captain. The night became wet and blowy, but I rather enjoyed the novel situation. Inlanders are fond of the sea. I came from the very centre of England, yet within a few miles of home many noted sea-captains originated, Anson, St. Vincent, Gardner, Child, and one or two other sailors of one's own kin. With the opening morning of Tuesday the Liverpool shore came in view, the weather drizzly, and the low shore looking strange and rather Dutch-like to me. The day, however, became finer, and when I had improved my toilette as much as I could, I sallied forth to view the town. The two Landers were then about starting for the interior of Africa, and preferring adventure and science to steady work, I should have been glad to have accompanied them. I presented myself at Sir J. Tobin's office at the Exchange, and offered my services as doctor and naturalist-inchief. I had no testimonials with me, but thought it might be sufficient if I affirmed that I was competent and willing. After being surveyed with some curiosity and surprise by the whole clerical posse, I was finally informed at head-quarters that other arrangements were made; in fact my destiny was not to be an explorer, much as I wished it, and well a.s I 
fancied myself cut out for it. What was serious, however, was that I had a walk before me of more than fifty miles, and my purse contained its last piece of silver. However, I got to the domestic hearth in due course, and, coming to the conclusion that the Liverpool clerks had perhaps formed the right opinion of me, soon settled down; my wanderings for the future being in a small way, and my propensity to them soon to be more easily indulged by the commencement of the locomotive age. 


\section{CHAP'TER II.}

THE SEABOARD.

London, one of the most artificial of cities, and the most removed from the rural, in many respects, in other's offers not a few attractions to the devotee of Nature and her works. Its steam-boats and railways, its river, its classical neighbourhood of park, heath, and wood, its collections, libraries, and learned societies, maintained by much of private and of public wealth, are all at hand to offer opportunities for his pursuits and researches. In a few respects a country residence is more advantageous to him; thus, to be an observer of the habits of animals-of birds, for instance-he must live amongst them, near their native hills, woods, and shores. Many charming books, as White's 'Selborne,' or Gosse's 'Tenby,' and 'Devonshire Coast,' could only be written, or at least the materials for them collected, amidst the objects which they describe; whilst, on the other hand, books of natural history written in London, however excellent in other respects, are deficient in one principal charm of such works - they want information on the havits and manners of the objects which they describe : such is the case with Yarrell's otherwise beautiful volumes. Still we must say of London, that a naturalist may be well content if his lot be cast among the citizens of the modern Babylon.

Once, when time for us was young, we were fixed for a year or two in the metropolis with a strong 
hankering for the microscope, botany, zoology, and such like, so as, in those days, to be considered by some of our friends as wilful wasters of our time and property. At the present time, when doctor's hope to cure patients by peering through the microscope, and surgeons pause in their bolder deeds to consider the theory of a cell or corpuscle, we should have risen to fame, and perhaps secured something more substantial. The celebrated R. Brown increased my liking for such studies by encouragement, and by showing me the beautiful paintings of natural objects made during Cook's voyages, and now in the British Museum. I was one of a party who used to meet at an evening rendezvous; Ross, Quekett, Griffiths, Valentine, and others were of it. The neighbourhood of London, indeed, as said before, abounds with objects of interest to such as myself; its very weeds are, many of them, rarities (botanically speaking) to an inlander, apparently belonging to a geographical flora, not extending far inland. I used to take stick-net, bottles, and basket, in pleasant mood, to Battersea or Chelsea, or higher up the river, and collect various molluscs and insects for examination, the tidal nature of the Thames there rendering it easy to obtain them. Unios, Anodontas, Paludinas, and the pretty little Neritinas are common; the last rare in the middle part of our island. Then, again, there were some of the prettiest ornaments of the fluviatile flora, the Water Violet, the Frog-bit, the Actinocarpus, the rare Villarsia, and the Water Soldier, found either in the river itself or its neighbouring waters. Twice was the world nearly deprived of two or three promising young naturalists-once in Chelsea Reach, when in search of the Villarsia, and again in passing through old London Bridge. I had also excursions down the 
river. I gathered the Leucojom or Snow-flake, and an unusual form of Cochlearia officinalis, on the margin of the Thames about Gravesend, which was at first my furthest journey. Some little peculiar shells are found in the marshes; and the chall excavations at Gravesend and about Tilbury and Purfleet abound in plants, many of which were very showy, and new to me, though it may be observed that the same plants are, to a certain extent, found both on chalk and limestone-the chemical constitution of the soil having great influence on the prevalence or nonprevalence of plants. The Fly and Bee Ophrys are both instances of this, and there are other more common ones. Crepis biennis and foetida are plants found here, but which, except upon some ballast-heaps in the north, are scarcely met with elsewhere. At Gravesend were obtained, for a trifle, a good collection of chalk fossils, principally, however, Ananchytes, Galerites, Micrasters, \&c., and which constituted the germ of a future geological collection.

The flat valley of the Thames is interesting from its singularity; its meadows and marshes are indeed monotonous, but they are made less dreary by occasional farm-houses, or pretty villages and churches, and, indeed, in places the scenery is hilly and wooded. But in the lower lands the stranger is struck with the never-ending embankments and their mysterious-looking sea-marks, and particularly by those great ships, which appear like gigantic skeletons, or, when their sails are set, like winged phantoms above the green banks or neighbouring trees and houses. Southend is not an unpleasant place; to get there, one passes Tilbury, and, further on, Hadleigh Castle, a rather fine feudal fortress in ruins, situated above the Thames, on an eminence by the 
roadside. I had a ramble about the cliffs of Southend, or rather the high banks of the Thames, composed of the dark red-coloured London clay. These cliffs are constantly mouldering away, and let fall septaria, curious formations of natural chemistry; crystals of selenite also abound, and the rather high shore is capped by beds of flint shingle, containing shells, such as now exist in the adjacent estuary; a proof, I presume, that the coast has undergone an elevation at a comparatively late era. London clay fossils, however, were rare. Here I picked the Teazle (Dipsacus pilosus), the Prickly and Willow Lettuce (Lactuca scariola and saligna), the Spotted Medick (Medicago maculata), and other plants.*

The corresponding cliffs on the opposite side of the river, in the Isle of Sheppey, are more productive in fossils. Leaving Strood in the steamer, we see Rochester Castle and Chatham to the right, and presently pass Upnor Castle, its walls being close to the Medway, and backed by thick foliage. Presently we passed through a fleet of war-ships bearing a variety of terrible names, more remarkable still as heard from the mouth of the tars, who are ready in their boats, at Sheerness, to convey strangers to view them; some from curiosity, others on business, and some from tenderer feeling perhaps. I landed, passed through the queer town of Sheerness, and ras shortly tramping over the low grounds of Sheppey towards an eminence on the estuary of the Thames, on which Minster is situated. To the right I saw one or two of those curious mounds attributed to the Danes, called Cotterels. The country bears rich crops, and the old church was situated amidst

* Still rarer plants grow in the neighbourhood, as Bupleurum teuuissimum, and Lathyrus hirsutus. 
fields of ripe and waving grain. I easily got down to the cliffs, where are found fossil fruits of a tropical character, crustacea, fragments of turtles and bones. There were some loads of pyrites collected in heaps to be carted off, each lump perhaps of an organic origin. Some of the selenite crystals were in shape like gigantic chess men, kings, queens, \&c. I also got fossils for a fer halfpence from some workhouse boys who had been enjoying a bath, but there are other more respectable dealers in the villages. I returned to Sheerness by the shore, watching the outward-bound vessels, many of whose passengers no doubt gazed as wistfully on the cliffs. The sands were not without Medusidæ, Zoophytes, and other specimens of natural history. Mya truncata and arenaria both inhabit the river here. Rupia maritima, the Glass-wort, and Oraches, and Goosefoots of not common species, abounded.*

I went on to Margate, and here the chalk cliffs abound with numerous plants which were interesting to me, and to a young botanist who joined me; such were the Tamarisk, the Hybrid Poppy, the Blueflowered Pimpernel, the Annual Mercury, the Saintfoin, and the round-leaved and pointed Toacl-flax (Linaria spuria and elatine). The place, however, is distasteful, from the throng of third-class cockney visitors, though it was pleasant on a fine day to follow the cliffs westwards towards Reculver, or eastwards to Fore Ness Point and the North Foreland. Along the beach I found the living ova of the Sepia, and, being light in colour, I concluded that they were near hatching. Putting them in sea-water,

* Limbarda, Diotis, Frankenia, Spartina stricta, Sedum sexangulare, Trifolium maritimum and Statice limonium, are also to be got on this coast. 
the little creatures soon escaped, and swam about by means of their fins, sometimes head, sometimes tail foremost; some had still the yolk-bag between their tentacles, and they occasionally ejected their ink, and changed colour upon their contractions. The ora were infested with a parasitical Anguillula. The limpets here excavated deep holes in the chalk, I presume by the rubbing of the muscular foot, aided by ciliary currents and gritty particles; certainly not by means of the shell, as it cannot rotate in the cavity, for it exactly corresponds in size to its oval form. The same cavities are found in other rocks, especially in the magnesian limestone of the Durham coast. Certain so-called jelly-fishes, Rhizostoma, Medusa aurita, and the pretty Cydippe or Beröe were lying stranded, the last showing a kind of phosphorescence when $I$ put it in water in an obscure place; $I$ also noticed that the circulation of the fluid contained in the internal ramified vessels was due to ciliary action. The little gem has often been figured, but never had justice done it, as far as I know. The cliffs eastwards are high, with inlets or bays, and here and there roads or tunnels cut through the chalk down to the shore, by means of which sand and kelp are drawn up. Near Kingston village we got into a fright, supposing a party had been trapped in one of the bays, by the rising of the tide, without a prospect of escape, for we noticed the gentleman of the party running about in it rather inexplicably. Our benevolence was, however, at fault; for, after getting a boat out to the rescue, we saw that there was a tunnel in the bay in question, and the party were looking on from the top of the cliff; our exit, therefore, from the little village was rather crestfallen.

I saw little more of the coast from the North 
Foreland to a spot a few miles north of Dover, where I came upon it again. Here great masses of chalk lay detached from the cliffs above, and there were abundant fossils to be had for the cutting out.* A most beautiful specimen of Cidaris fell to $\mathrm{my}$ lot. I noticed the true samphire on a rock unusually low, and filled a handkerchief with it, which was afterwards pickled secundum artem, and I have liked the curious flavour ever since, from associating it with this pleasant ramble. I found accommodation at an isolated house close to the beach, to the north of the town, and spent a few pleasant days there with my microscope. The cliffs afforded Squinancy-wort (Asperula cynanchica), Linaria minor, Brachipodium pinnatum, and some other plants common on the Derbyshire limestone; also some sea-plants, as Crambe, Beta, Brassica, and Sinapis of species found on the coasts of North Wales. Early one morning I left the town and its castle behind, and proceeded on my way to Folkestone, then a mere fishing village. Under the lofty Shakespeare's Cliff I first found the Chiton (fascicularis and cinereus) sticking to the rocks, and, in a little sandy bay further on, Ophiura lacertosa, the Lizard Sand-star, in abundance, twisting and sprawling in the sand, a species which I have rarely found since, or at any rate in such plenty. The C. fascicularis had eighteen fascicles of bristles; the tongue was very beautiful, with about twelve pairs of muscles. I ascertained that the ovaries and renal organs opened between the branchial processes on each side. A little further on, abundant fossils of the Gault arrested my notice, both strewed on the shore, and

* Specimens of Terebratula, Rhynconella, and Spatangidæ, if I may coin the last word. 
also imbedded in the cliffs; in the first case often eroded by the sea-water, in the other very perfect and splendent, with highly-coloured nacre. They consisted of Nuculæ, Tnocerami, smooth and sulcated, Ammonites (splendens and others), Baculites, Hamites, and Belemnites without number. I put up at a sinall inn, then the best in Follestone, and fortunately came across a curiosity fancier like myself, but of a still humbler grade, who, for a trifle, furnished me with shells and fossils, and also pointed out the localities of Orclids and other rare plants to be found on the neighbouring lofty chalk downs. Ophrys fucifera, muscifera, arachnites, and apifera, or Drone, Fly, Spider, and Bee Ophrys, the Lady's Tresses or Neottia spiralis, and the dwarf Orchis (O. ustulata) are all to be picked in their season. Hippophäe grows on the Undercliff as well as the little grass with the curious name Rottboellia. The next day I went out in one of the trawling-boats, but we kept pretty near the shore. My portion of the spoils consisted of Cuttles and Squids; Bullæa aperta, strangely enough considered by the fishermen to be the young of the Cuttle-fish; two pretty little bivalves, Corbula, and Nucula; the prickly and Norwegian Cockles; several species of Scallop; and Crabs and Echini or sea-urchins in abundance. On the coast near Hythe I picked up a smaller species of Squid (Loligo media), extremely beautiful for its transparency and colouring; the little Sepiola was also evidently common, as I found its ova often enough, and they produced the young Sepiolæ when placed in sea-water, moving, not like the Sepia above described, but by the impulse of the sac contractions on the water, though they have small fins. These contractions were about fifteen per minute, the pulsations of 
the three hearts thrice as frequent. The eggs in this case are, unlike the Sepia's, aggregate or compound, each grape, as it were, of the bunch being composed of many ova, and elongated and colourless. I noticed that there were no cilia on the branchir of any of these cephalopoda, though other mollusca all have them; the mechanism of respiration renders them unnecessary.

Sandgate Castle is passed in the walk from Folkestone to Hythe. Some say it was at the latter place that Cresar landed. At this time the writer had conceived little taste for antiquities, ecclesiological or otherwise, so that he passed many spots-in Romney Marsh, for instance-which he would now like to revisit; neither had he learned his geography sufficiently well to know that there have been said to be five quarters of the globe, 'Europe, Asia, \&c., andRomney Marsh.' With respect to plants, about Sandgate there are several curious little shore weeds to be picked, as Trifolia of three or four rare species, and, more inland, Ophrys apiferc and the striated Catchfly, Silene conica. At Hythe, seeing some quarries on an elevation at a little distance, I made for them, and was gratified in procuring abundance of fossil shells, bivalres principally, belonging, I concluded, to the Lower Green-sand. I also got a living Teredo out of some old stakes at a bathing ground, at that time said to be extinct in England. The next morning, after a stormy night, leaving Romney Marsh behind, I was at the mouth of Rye harbour, not very far from the spit of land called Dungeness, a dreary-looking place, with a lighthouse near its extremity. Camden says the Sea-pea, Elecampane, and Sea-calamint grow on Dungeness; the first (Lathyrus pisiformis) certainly does so now. The sands about Rye Inlet were strewn with specimens belonging to most of the zoological 
divisions-Sea-urchins or Echini; Sea-hearts or Spatangi (S. cordatus and purpureus); Zoophytes; Annelides, as the Sea-mouse and Pectinaria Belgica, with apparently a second species; Razor-fish and other bivalves, as Syndesmya alba, and Tellina fabula and tenuis, Mya, \&c. The intestinal canal of the Sea-mouse has about twenty long puckered cæca on each side; there is a dorsal and abdominal ressel with side branches; the dorsal or respiratory plates under the integument are ciliated; the ovaries open below on each side in every segment of the animal. The Razor-fish had evidently the power of distending the foot with water, admitted by a hole at its back, a faculty common in bivalves. Towards sunset I sought refreshment at a kind of hotel in the desert of shingle below Winchelsea, but did not like the looks of the place or company. I then bent my steps towards New Winchelsea, as it is called, interesting nevertheless for its antiquities, but hardly entitled to send members to parliament, which it did about this epoch. All I saw of the borough consisted of the church of St. Thomas à Becket in ruins; a conventual building, ditto; a court-house, hostelry, a farm-house, a few cottages, some walls, and three gateways; at least I saw nothing more, but it was getting dusk certainly. Old Winchelsea was destroyed by the sea, its site being marked in Camden's map some way out. Dungeness is increasing instead of being swallowed up, and New Winchelsea in the same manner has its quondam harbour turned into the stony waste mentioned above. It would seem, therefore, as if the sea had for half a millemnium been receding where it had previously been making inroads. I regretted to leave, by the renerable ivy-clad New-Gate, which leads towards Hastings, with so 
slight an examination of the remains of a once large mediæval town, raised by that great builder Edward I. Towards the last-named place I now bent my steps over the high cliffs, knowing that if I followed the shore I should get to it. Pleasantly the full light of the moon fell upon the ripples of the now calm sea, broken here and there with a small craft. It served me also to find my way over the cliffs; but I got to Hastings with some fatigue, meeting, however, with no danger, except the risk of being shot at in mistake for a smuggler by the coast-guardsmen, who seemed numerous and well-armed, but were disarmed when they saw the non-contraband nature of my paraphernalia. The way led over hills and through valleys and some thickets; one place at a little distance from the town being called Fairlight Glen.

At Hastings we went out several times in the trawling-boats; they fished either near land for two or three tides, or further out in the Channel, on a ground called the Diamond. I have a very pleasant recollection of the hot coffee in the early morning, boiled on the fire, at the bottom of the vessel, and of the delicious fish just taken from the water and broiled an naturel. The jelly-fishes (Medusa aurita) were injurious to us, their vast numbers buoying up the nets and allowing the fish to escape; the machines were heavy enough, however, for they had to be raised by a windlass. We generally got a good batch of Skate, Plaice, Soles, Turbot, Brill, and such deep swimmers, with others of no value, but some of them more interesting to me-the Cat-fish, for instance, and the Weevers, poisonous creatures, of whose spines the fishermen had a wholesome dread. In my share of the booty was the splendid Asterias cartilaginea, looking like some rare and magnificent flower. The 
fishermen were foolish enough to throw orerboard alive the Cuttle-fish, though they are very destructive to the finny tribe, besides being themselves eatable; they covered me with their ink in handling them; they abound here, whilst, on the contrary, I never saw one, nor picked up their shell, or bone, as it is called, either on the Manx or North Welsh Coast. My friends sold their fish immediately on landing on the beach by Dutch auction. I had many pleasant rambles on the shore, both east and west. I got a beautiful species of Wrasse from one of the prawn-nets, and was pleased to find Actinia dianthus under the rocks below the East Cliff, the spot in which it was first noticed by Ellis : it is now well known, and may not remain there in these aquarium days. Peachia or Actinia chrysanthellum occurred on the same part of the coast. I also met with a family of the smallish mottled Doris (D. verrucosa), which I have taken once since at the Great Ormeshead, also their ribbons of spawn hanging from the rocks. I got likewise the papillose Eolis, and Homberg's Tritonia, and dug out three or four species of Pholas from the rock and submarine peat at low water. I also made a little discovery that almost every Whelk-shell in which a hermit crab had taken up its residence was inhabited in the back spire by a large species of Annelide (Nereis bilineata?), the two dwelling in perfect amity, and probably subservient to each other. The worm was a foot or more long, with four eyes and a retractile proboscis, having two rows of hard pieces within. I remarked that a minute Annelide, Syllis phosphorescens, produced the phosphorescent spots of a yellowish green tint which bespangled the nets of the fishermen when drawn up at night. I noticed likewise a Glyceris, with long antennæ and conical 
snout, enabling it to burrow easily in the sand, during which the antennæ were beautifully shielded by the side processes; it had no eyes. There were beautiful Sabellæ as well as Holothurix on the Oysters and Scallop-shells in the market, living in sandy or membranous tubes. I observed the former to be very keen of vision, and found their two eyes: the $N$. bilineata, above mentioned, has four, and is also equally sharp-sighted. The holes made by the Iumbricus marinus in the sand are always in pairs for head and tail, and the same thing is seen in fossil annelide markings from the older Silurian rocks.

I had taken up my abode with a person who appeared to be half fisherman and the rest smuggler. He, however, procured me curiosities, and one or two baskets of refuse from the trawling-boats, the presentation of which covered his other delinquencies; he also gave me the run of his little garden, and unlimited use of pans, jugs, and pails. I put some common Scallops or Pectens into a bucket of water, and they had no difficulty in swimming about, and even jumping out of it. It was curious also to see the Spiny Cockle, in the same situation, hook itself along very actively by means of its curved and richly-coloured foot. I got many other molluscs for examination, * and there was a quantity of Ascidia aggregata in a small rock-pool below the East Cliff.t I met with the Undivided Antennularia upwards of a foot high, and a branched

* Triton erinaceus, Pecten sinuosus and rarius, Natica glaucina, Pectunculi, Mactra stultorum and several specios of Venorupis alivc; also Patella pellucida, Scalaria clathrata, Rostellaria, Fissurella, MIactra solida, Lutraria vulgaris, Artemis exolcta, and Amphidesma compressa and alba.

+ Also Cynthia rustica, Pandocia conchilega, Ascidia intostinalis, and Alcyonium gelatinosum occurred. 
sponge, quite as tall, was brought me from deep water; it was divided, brownish, and hispid, no doubt Halichondria palmata.*

On the East Cliff grew the Tamarisk and Seastock (Matthiola), and other plants more or less characteristic of Sussex were to be found-some about the castle, and others on the lower part of the shore. $t$ The Calosoma sycophanta, a rare and beautiful beetle, is taken here, and I obtained one, though not of iny own capture. I got a few specimens of Wealden fossils from the rocks at the west of the town, at that time dislocated and lying in great masses. In the sea further on, beyond St. Leonard's, near a gentle eminence called Bexhill, the hull of a Spanish vessel, wrecked many years ago, was visible at low water. In some salt marshes lay great quantities of dead shells of Scrobicularia piperata. The low part of the coast is remarkable for its Martello towers, placed at intervals. Further on was Pevensey Castle, on the same low ground; further on still Beechy Head, shining white in the sun. The Gault appeared to me to be visible at the foot of Bexhill.

Philosophers avoid fashionable places, aud so did I Brighton; but one beautiful morning I was put down near the old arch in Southampton, and was soon wending my way by Southampton Water towards Portsmouth, collecting what I could find by the road, and lingering half an hour amongst the ruins of Netley Abbey, and making a sketch of the east end of the chapel, in the window of which much of the tracery still remained. The Belladonna grew here

* I also met with Flustra papyracon, Cellularia salicornia, Crisia eburnea, Eucratia chelata, Sertularia abietina, Polyzonias halecinum, pumila, and pennatula.

$\dagger$ Bupleurum, EEnanthe pimpinelloides, \&c. 
by the waterside, a rather unusual habitat, I fancy; also the Sea-starwort; * and nearer Portsmouth I picked the Butcher's Broom (Ruscus aculeatus) and the Proliferous Pink (Dianthus prolifer). I also noticed the Sea-grass, Zostera, in a creek over which I was ferried; and that the gorse on a common near the end of my walk was hoary with that curious little parasite the Dodder. On the west of the opening of Southampton Water stands Calshot Castle, the work of Henry VIII.

From Portsmouth we of course went across to the Isle of Wight, but in the following historiette, if I may use such a term for my unpretentious account, we shall combine a few notes taken more recently on a second visit, and so in one or two other instances. Viewed from the sea, the lower lands formed by the fluvio-marine deposits are nearest, constituting the north of the island; in the distance are the Chalk downs. The Solent and Spithead are channels cut through the trough formed by these fluvio-marine or supra-cretaceous strata with those of Hampshire. There is a second ridge of chalk further south, and between the two ridges the denuded lower cretaceous system or Green-sand appears. On the south-east side of the island, and more extensively on the southwest, the Wealden rises from beneath the Green-sand. The island is about one-third less than the Isle of Man, and the population also is (or was) less by about a third; but this at a rough estimate. The Isle of Wight is, however, more fertile and cultivated; but homesteads are much less distributed throughout, and probably the properties are much less divided.

My first visit from Ryde was to the quarries at

* Linaria repens, Molampyrum cristatum, and Melittis also grow in the neighbourhood. 
Binstead, a pleasant walk before breakfast. Fossil fresh-water shells, Lymnæi and Planorbes, were plentiful enough in the yellowish rock; seed-vessels of Chara, fragments of fresh-water turtles and of alligators, with some bones of Anoplotherimm and Palæotherium, have also been found here; in fact the formation is the representative of those Paris beds which furnished such a rich harvest to Cuvier. The roads of the island, like those of Jersey, are often lined with trees, overhanging and meeting at the top. We put up next at Sandown Bay, on the south-east coast; hence a pleasant walk of about five miles, over hills and through rustic lanes and woods, leads the pedestrian to Bembridge Point, where he may procure similar fresh-water shells to those from Binstead, to be got by breaking up the sandstone at low water. There is a pleasant avenue, with the trees meeting above, leading from the Point up to Bembridge village. As we sat here, a party of children were merrily waltzing, singing, and playing, exactly à la Watícare; some way down, and behind them, was seen the shining sea-a pleasant scene. At a cottage we noticed the Leycesteria formosa in full bioom; and other garden flowers, as carnations, were very luxuriant. The bastard Toad-flax (Thesium) grows on the Chall downs.

We also visited Whitecliff Bay, keeping along the eastern cliffs, an interesting spot for geologists, as here the Eocene strata appcar in a continuous series in natural section, and with the respective fossils of the beds easily attainable; the chalk on which they repose is strongly marked by the lines of fints, and these show how much it is tilted up southwards. The fossiliferous Eocene strata are defined below by a bed containing the little pteropodous shell called Ditrupa, the first beds succeeding the chalk being 
devoid of organic remains. Then succeed, much inclined, beds containing Panopæa, Pectunculi, and other shells; then unfossiliferous sands and clays again ; and above, the London clay proper, with immense numbers of shells, bivalves and univalves, nummulites, \&c., natives, it would seem, of a warmer climate than we have at present. These strata are followed by the Pliocene (Bembridge), lying more horizontally and unconformably upon them, and deposited, it would seem, from an estuary or such like. Some remains of reptiles and crustaceans have been found here in the London clay-beds, and sometimes the strata present alternate deposits of fresh and salt water character. The impression of a palm-leaf is figured by Mantell from this locality. A good-natured collector happene to be on the spot, acting as guide to a geologist; he pointed out to me the different strata, as characterised by the Ditrupa, the Cardita, ard the nummulite, and I afterwards, in return for his civility, called at his cottage near Freshwater, and made a few purchases. But it now beçan to rain, and in wet seasons London clay localities are miry places.

Nearer Sandown the highly-inclined Chalk forms Culver Cliff, and on the Sandown side of the last rise up the Firestone, Gault, Green-sand including the Perna bed, and the Wealden. We were looking for specimens here, when a young gentleman, seeing my chisel and hanmer, asked if I could procure him a fossil thunderbolt; we found he wanted one of the little bullet-like pyritic formations which we had noticed in the rock. On enquiring where he went to school, we found he had finished his education at a first-rate establishment at Brighton. A new fort was being formed here, and a jaw which was dug up was 
offered to us as that of a Palæotherium, but having a geological book by us, we could not see that its dentition at all agreed with that of those extinct pachydermata. Bones of the Iguanodon are, however, discovered on the shore, and at a shop in the town were some of the huge toes and vertebræ on sale. The Cyprides and fresh-water shells of the Wealden, with the fossil cones of tropical plants, are also to be met with. In one of our walks on this side we passed the interesting little church of Yaverland, with a mansion hard by, both embosomed in trees; the latter once the residence of the high-born; now, however, a farm-house.

We had also a long walk westerly, between the cliffs and the sea at low water. There were good specimens of the Thetis in the dark-red ironstone of the Lower Green-sand, to be obtained from blocks lying on the shore, and we found imperfect bones of reptilian animals, and in fact here is one of the best places to look for them. We walked through Shanklin Chine, a romantic glen, and one of the 'crack spots' of the island. The stream flowing down it is not the most delectable, being evidently tainted by the drainage from the village above. There appears to be a good trade done in the island in polished agates, jaspers, chalcedonies, and cornelians; beautiful pebbles are found at Atherfield, and they also cut and polish choanites and other fossils, and silicated wood. There was an establishment of the sort at the mouth of the glen at this place, with very pretty articles, but from various localities, and the man showed me a piece of glass (so we fancied) enclosing glittering particles, but which he called aventurine, and for which he asked a high price; it certainly was very pretty, though counterfeit. I found a good-sized Octopus here on the rocks, the only one I ever met with; 
Padina pavonia grows on them. We descended, on trespass it turned out, the next chine (Luccombe), and walked under the cliff past some fishermen's houses; then past the landslip and the little church of Bonchurch to Ventnor. Under these cliffs grew the Everlasting Pea, Lathyrus sylvestris; also the Madder, and Asperula cynanchica.

Ventnor is in many respects a beautiful place, the vegetation, for instance, being superlatively rich. There are several plants luxuriating in the open air, which we had not seen before; for instance, we noticed two beautiful hedges, one apparently of a species of Atriplex (A. halimus), the other of a laurel-looking plant (Euonymus latifolius?). The gardens and enclosures were extremely pretty, including here and there portions of the fallen cliffs, covered with rich regetation. The Undercliff is a good locality for Chalk and lower Chalk fossils, to be picked up or purchased for a small sum from one or two humble collectors; there are fine specimens of Nautilus and Ammonite, and also Siphonia Websteri. One morning, however, was a short time to explore Ventnor. We found Orchis fusca in a thicket in the Undercliff, and the Fotid Iris abounded in places; the Bird's-nest (Monotropa) and Silene Anglica are also to be found. We passed by St. Lawrence's Chapel, an interesting little place, with some affecting memorials of shipwreck within its small enclosure, the sea and road at hand, and some pines and the cliff in the background; then by Niton and Blackgang Chine. I had but one ramble on this part of the coast, and that was in the early morning before breakfast, walking from Brixton. Here are noted localities for the fossils of the Green-sand and Wealden.* Brook and Atherfield are the subjects of

* The most curious of the former being Terebratulæ, Gervillia, Perna, Gryphæa, Pterocera, and Scaphites. 
interesting accounts by Mantell. The lower beds of Green-sand (Neocomien) are especially developed at Atherfield, characterised by an abundance of fossils, including the Atherfield Lobster, and lying upon the Wealden clay, with its own characteristic freshwater shells, Cyclas, Unio Valdensis, Paludina, \&c. Brook Point is remarkable for the remains of a fossil Wealden forest, and here and at Compton Bay Wealden fossils may be met with. The trees are not upright, but overthrown and pyritic. The fossils are Cycadeæ, Zamiæ, fern-leaves, and other vegetables, and, besides these, fresh-water shells and fish remains (Lepidotus and Hybodus) at Brook; and there, as well as at Compton and Brixton, bones of Iguanodon and otler reptilians.

Our party drove down to Freshwater Gate; here the waves were dashing in wildly, and the place was so delightful that we spent three or four days at it. There appeared to be several barrows on the downs, as well as the tomb of a little child, with whom a melancholy story is connected. At low water one may walk to some curious perforated rocks. We found quantities of little Cuttle-fish (Sepia)-shells here, being all of one size, with no larger ones, so that I suspected they might belong to a new species; probably not so, but we don't see why they should die in such quantities at that particular stage of growth, unless it may be from their having been swallowed by some fish, and the shells afterwards disgorged. We were told of some elephant remains having been found in the drift here. Round the high chalk cliffs to the right, at the very extremity of the island, is the wild spot called Scratchell's Bay. Here birds'-eggs and samphire are collected from the challk cliffs, and all the common sea-birds are found- 
Puffins and Razor-bills, Gulls, Guillemots, and Cormorants; the two former excavating holes for their eggs, the others not. Further on are the Needles, helping to form the left side of Alum Bay, as Headon Hill does the right.

Of course the geologist visits this spot, classical to him, as well as the two other bays to the north, first Tollard, and then Colwell. Not to be behind, we visited all, and with a pick and spade could have got fossils, Cytherex, \&c., enough to supply all friends, many being beautiful in figure, and wonderfully preserved, tumbling out most delightfully when the sand or clay is dug into. Descending the common, above the bay, we noticed a little vessel near the Needles with a streamer flying, and a sailor eagerly watching it through a glass; it had got on the shingle, he said, and the streamer betokened distress ; presently, however, with the rise of the tide it got off. The strata, in which there is an alternation of fresh and salt-water formation, are a repetition of those at Whitecliff, but the scenery is more interesting: there are the lower or Bognor beds with Ditrupa, Vermetus Bognorensis, and sharkteeth; then come the variegated sands of many pretty tints, with which the well-known sand bottles are filled; then follow marine strata with shells. All these are to be found to the left of the chasm which descends to the bay, with, however, a portion of the marine strata to the right, after which we meet with the fresh-water strata of Headon Hill, which are more or less horizontal, unlike the vertical strata to the left, but dislocated, however, in wild confusion. Beds of oyster-shells occur with the fresh-water shells; and remains of the Hyopotamus, Palæotherium, and Crustaceans are found. In the 
chalk-marl of Alum Bay occur impressions of leares like those of the Maple, Acacia, Palms, \&c. Plenty of loose fossil-shells are to be met with on the strand.

The village of Freshwater is curious, from being two or three miles in extent; indeed we never could find a village proper, so scattered it is, and so unlike those of manufacturing mid-England. We found the church, however, on Sunday, and it was crowded by opulent people, mostly visitors no doubt, as well as by a handsomely accoutred corps of horse soldiers. I found that my friend, mentioned above, had larger collections of the fossils of the island, as well as Hampshire specimens, including interesting mammalian remains from Headon Hill, Hampstead, Bracklesham, and other places; but the latter we did not bid for, leaving them for the Owens, Huxleys, and other scientific magnates. We also found bird and egg collectors ready to sell.

We made an excursion to Carisbrook, of which the gateway is the most interesting part of the ruin. Here, as is well known, was the prison of the illfated Charles, martyr, or not quite so good, according to one's political creed. We picked Thesium below the castle walls, and Astragalus hypoglottis and Teucrium chamodrys are also to be found in this locality. We were pleased with the remains of a Roman villa, not far from Newport, which are carefully preserved, and apparently a good penny made out of them, which goes to the church: there are the basement walls of apartments and baths, and one large tesselated pavement, over which a roof has been erected. We left the island at Yarmouth. As we descended to this town from the high ground, we had a fine view of the Solent, of Hurst Castle, of Fort 
Victoria, and of Hampstead, lying to the right, a noted spot for fossils, considered to be higher in position than those of Bembridge or Headon Hill; behind we could catch a glimpse of the Needles. In a short time we were put down by the steamer at Lymington, on the borders of the New Forest.

The extent of my rambles westwards at this time was Purbeck Island. I stopped late one night at Wareham. At the little inn I saw on the mantelpiece specimens of the Kimmeridge coal money, so called, which mine host let me have. Corfe Castle is one of the most interesting spots I know, very picturesque and secluded for this part of England. It was advanced in the night when, after passing the long dreary moor, I got between the steep hills, on one of which the castle is situated. However, I was hospitably taken in and entertained. Next morning, when I looked out of my window I was charmed with the sight of the ruined walls of the castle, and soon had a stroll in that direction, some merry schoolgirls acting as my guides, showing me the spot where the martyr Edward was surprised by the treachery of Elfreda. I dug up several plants, which I afterwards transferred to my garden as memorialsSalvia verbenacea, the Gladwyn, \&c. The masonry is truly as compact as the solid rock, and large masses of the walls have been thrown down the hillside without disintegration. With a heavy hammer I knocked off some specimens of the Purbeck marble, entirely composed of a little fresh-water shell ( $\mathrm{Pa}$ ludina), a less species than that in the Wealden formation. I have noticed that in central England the Purbeck stone weathers a great deal in out-door architecture. I afterwards was taken down to the coast by two friends, a geologist and a doctor, visiting 
on the way several barrows, one of which had been cut through by the road, and the enclosed bones strewed about. We crossed a lower valley, but which was still, I presume, elevated above the level of the sea, and where was a tufaceous deposit, in which were abundance of oyster and limpet shells, also land shells, and bones, showing that the sea at no remote period extencied thus far, though now a few miles off, and that formerly Purbeck was a bona fide island. The stone walls afforded good specimens of a bivalve shell, and at one of the cottages situated in a dell opening to the sea, at Chapman's Pool and below St. Aldhelm's Head, I was offered the enormous humerus of a Plesiosaurus, which had, the cottager said, fallen from the cliff; but as I could not well lift it, and was two hundred miles from home, I was obliged to decline the good-natured fisherman's offer. The shore presented sections of the Kimmeridge clay, abounding in fossil wood or Kimmeridge coal, fossil oysters, and Nautili, of which last there were also some enormous specimens, but in stone, lying on the shore. A very interesting museum of antiquities and geology has been formed in Corfe. We got some fine specimens of leaves from the clay of the lower Bagshot sand formation, dug in the neighbourhood, lying near the chalk, and supplying most of the potteries of Great Britain, and which, mixed with flint, forms the ordinary white ware. Insect remains have been found in it by Mr. Brodie, extremely interesting; and little bullets of pyrites occur.*

On the top of St. Aldhelm's Head is a chapel with

* On the shore the cottony Diotis, Limbarda, Asparagus, and other more common plants occur; and on the heaths about Corfe are many interesting plants-Erica ciliaris, Exacum, Pinguicula Lusitanica, and Droseræ. 
a central column and Anglo-Saxon doorway, now used by the coast-guard, but formerly occupied by a monk, who lit its beacon light, and said masses for the safety of mariners sailing off this picturesque but dangerous promontory. A section of the strata of the promontory is best seen in the sail from Cowes to Poole on the east side, passing Studland Bay and Swanage; the Portland Oolite of the south extremity being successively overlaid, as one goes northwards, by the higher strata of the Wealden, and the other formations, up to the London clay. At Swanage a crocodile and remains of turtle have been found. The Portland stone at Tillywhim contains Ammonites, Trigoniæ, beds of oysters and other fossils, the scenery being also very romantic. There is a descent by steps, cut out of the rock, to the cavernous quarries. I got few marine productions, and it struck me that part of the shore was unfavourable to them, from the pyritic character of the Kimmeridge clay producing by its action on the sea-water the evolution of sulphuretted hydrogen-right or wrong, I cannot say. I procured living specimens of Bulla hydatis and Akera bullata from Poole, and other shells are found on the coast.*

At the mouth of Poole harbour is Branksey Island, where Camden says was in his time a family of the name of Clavell, who are mentioned as living on the spot in Domesday book. After I left the coast, I had forwarded to me by one of my aforesaid friends a portion of a drift-log covered with Lepas anatifer; it had been driven on shore at Kimmeridge in stormy weather. The creatures were all living, and I placed them, after a journey of two hundred miles, in artificial

* Dilplodonta rotundata, the large Cyprina, Venus fasciata, Pandora obtusa, and Lucina lactea and leucoma. 
sea-water, in which they continued to live for some time. They were quite sensitive to light, and I discovered that the deep eye-speck was not, as has been said, impermeable to its rays, but only covered with a small transparent portion of the otherwise thick and opaque envelope, well adapted to allow the light to penetrate to the little organ. Minute as these parts are, their disposition appears to me an instance of an evident design, independent of any common law of organisation or formation; for what physiological or physical cause could have produced that little transparent cornea in the common integument? We took our leave of St. Aldhelm's or Alban's Head, casting a look westwards towards Weymouth and Portland, and noticing some large objects in the distant waters, which we were told were the hulls of some of our giant war-ships.*

* An entomologist gare me the Galathæa, or marbled white butterfly. which he had eaught on the Studland hills; also the Lappet Moth, the Gold-tail, and the Red Arches from about Poole; and the Lulworth Skipper, plentiful at Lulworth Burning Cliff. 


\section{CHAPTER III.}

\section{THE ISLAND.}

As might be inferred from its intercourse and trade with all parts of the world, the naturalist will sometimes meet in the streets and shops of Liverpool with objects to interest him. At a meeting of the British Association (the British Ass. my lady-friends sometimes call it), held there some years back, a member observed, in his section, that he never walked out there during his visit without meeting with a new species of shell or animal of some sort. From the shores of the Mersey we have obtained large specimens of foreign cirripedes or barnacles, still containing the soft parts, brought from hotter climates, adhering to the bottoms of ships. A walk on the Cheshire shore, around New Brighton, we found by no means uninteresting, botanically speaking, especially as we were previously better acquainted with inland than with maritine plants. The otherwise barren sand-hills were covered and ornamented with the fragrant Burnet Rose, and with a variety of Ononis, and also enlivened by the Autterings of the Scarlet Burnet Moth. Numerous plants, many of them rare or interesting, ${ }^{*}$ are found in the promontory between the Mersey and the Dee, some peculiarly maritime, others 'weeds,' but not common ones, as Flix-weed, Sisym-

* Neottia spiralis, Silene Anglica, the tutsan or Hypericum androsæmum. The English name of the last corresponds with the French toute-saine; the name flix-reed occurring in the text is a corruption of flax-weel. 
brium sophia, new to us when we dropped upon it here. On the shore lay abundance of jelly-fish or Medusidæ, and we picked up several Sand-stars (Ophiura lacertosa). At some distance from the shore is a reef of mussels, and cockles are likewise numerous, amusing the novice in sea life by spirting the water from their mantles; we also noticed a more delicate shell-fish than either of the last, and in considerable plenty-the Pholas candida, which we dug out of the remains of a submarine forest between New Brighton and Hoylake. There was the stock cf a tree still rooted and projecting upwards a foot or two in spite of the waves.*

At Liverpool I pat up à la Miller at a Temperance Hotel, a handsome house, and, as it was late, soon got to bed, but to be disturbed after midnight by the landlady coming home, I suppose from the play, and unquiet enough, but we must hope temperate; - to sleep again, but, alas! soon to reawake-this time from the attacks of certain little creatures abounding in this town, against which I hereby warn all travellers, even though they should by chance be entoinologists, to guard. Though my night was perfectly sleepless till break of day, when my foes did not belie their lucifuge instinct, I felt exhilarated enough after breakfast when I found myself on board the Benma-chree, steaming bravely down the rive:, past the fort and lighthouse, and threacing our way amidst numerous black and white and red buoys, and strangelooking sea-marlis and beacons to indicate the channel; and so past the grim lightships, till we got

* Pholas crispata, Mya truncata, and Soicn ligumen also live about the embonchure of the river. I have noticed Scrobicularia piperita aud Mactra subtruncata as high up as Runcorn. Sertulitia argenten, abietina and operculata, Notamia loriculita, and Tubularia ramosa, aro picked up at New Brighton. 
fairly out of the muddy river into the blue sea. To the left, in the distance, were the Ormesheads, but midway in the passage we lost sight of land altogether. The day was calm; numerous medusæ glided past, various gulls and guillemots were on the sea, often in large flocks, and a herd of porpoises, called herring-hogs by the Manx captain, were gambolling about when we got two-thirds across, but they kept a good distance from the vessel.

Seen from this side, the Isle of Man looks in the distance like three islands, from the rotundity of the earth and the little elevation of parts of Mona itself. But what appears to be a small islet at the southern extrenity is not, as might be supposed, the Calf, but that portion of the island which is joined to the rest by the low ground leading from Poolvash Bay to Port Lrin. The island also looks as if it were divided further north, this being caused by the existence of the low valley between Douglas and Peel. It is from the same causes that several miles of the low lands of the north, with the Point of Ayre, are also invisible, looking towards them from a distance. As the steamer approached Douglas Bay a gun was fired, to which there was a response from St. Ann's Fort. The lighthouse, built on a rock on the left hand, is passed, then a second castellated building, called Harold's Tower, most picturesquely situated. On the right is seen another castellated building, the Tower of Refuge, built upon Conaster Rock, in the centre of the beautiful bay. Banks's Howe is the name of the promontory bounding the bay to the right. These are all left behind, and we are soon at the pier-head.

The day after my arrival was Sunday, and as the Manx are, ostensibly at least, a religious people, often perhaps, like the Welsh, visionary and super- 
stitious, I made no long excursion. Chapels appear to be much more numerous than churches, and there was out-door preaching, by the regulars however, in the afternoon on the quay. My friends went to conventicle in the morning, and I with them, but I did not feel obliged to sit out a second long discourse in the afternoon, and therefore climbed the headland, and at one place the rocks looked so tempting that myself and a friend with me yielded, and got down, myself however to be punished, as I tripped, slid down, and suffered a rent in the habiliments. What was worse, both of us, being notorious characters at home, seldom went out at any seaside place without meeting with some acquaintance or other; and so on this occasion, though we intended to slink home quietly and unrecognised. A lady was sitting with her husband on the headland above, and, as we returned, accosted me with, 'Well, Mr. A- - how do you do? Do you know I thought it must be you, when I saw you searching the rocks, and told my husband so. When did you leave home, and what have you got in that little bottle?' and so on. Of course I said how glad I was to see them, and hoped to call on them in Love Lane, where they resided; but I felt anything but glad, or fit for a Sunday presentation, particularly on a back view; so we retired as from the presence of royalty, nor turned round till far enough off. A few days afterwards, in passing through Ballasalla, a village in the interior, an old withered crone, without bonnet or cap, presented herself with tracts for sale, and we understood that a prophet (as he was called) lived somewhere amongst the hills above, and printed his religious effusions for the old woman to sell. She was also disposed to enact the sybil herself, and foretold 
speedy sorrow for the earth, apparently a little the more bitterly as we did not appreciate her merchandise.

In the south of the island the inhabitants are somewhat short, with darkish hair, though in the children it is lighter; their eyes also are lighter; they seem but a slight remove from the Erse. Fair hair and blue eyes, with a taller stature, are more common in the north of the island; and here the names alsu are often Scandinarian, by which race-formerly the lings of the seas - the isle was once kept in subjection. Even now Norwegrian vessels are very frequent in the ports. Drink appears to be the great curse of the island, and of those who frequent it, for many of the natives themselves have very wisely become abstainer:s from the cheap but ruinous stuff. The Manx cais often understand pretty well both Frse and Gaelic; the words, but not the accent and pronunciation, being the same in each language, all three people constituting one division of the Celtic race, the Cymri being the other. The Scottish Highlander is, however, most easily understood by the Manxman. There is a difference in accent in the north and south of the island. Some of the customs are of Celtic, if not of Phomician origin, as belteine fires on May-eve, which are still kept up. Carreens, or sandals of untannol skin, are still occasionally seen. A refreshing drink, or rather meat and drink, called benjean, is made? from half-coagulated milk with spice. There are other peculiar customs and superstitions.

I tried my dredge on four occasions beyond the bry of Douglas at 40 or 50 fathoms. Some fine Echini and some Pectunculi (both forms) were all we obtained at first. We aiterwards captured the beautiful little rosy-Sea-star (Comatula), looking Jike a 
moving crimson floweret. On the first expedition we had a chapter of accidents, and ladies were in the boat; the dredge first got foul of the anchor of a herring-boat, and as it was being extricated we got under the bowsprit, which kept bobbing down upon us, threateuing every moment a smash; we next got entangled with what is called a deep line, and had to pull all up together, the fish, as plaice and skate, attached to the hooks into the bargain; but, what was worse, we began, amidst these mishaps, to be driven out to sea, both wind and tide being against us. We pulled as much as we could, myself but a bad hand at it. One of our men said he could row no longer, and vented his feelings in curses on the boat; in fact it was too heavy for only two oars. The other behaved better and did not give in, but we vainly tried to get under the shelter of the headland, and at last were two or three miles out. The ladies behaved capitally, one saying she did not care as long as there was a plank under her, but she was of a race of sailors. There were but two vessels in sight, a brig and a Castletown herring-boat. We had a short debate, and put out a fiag of distress-a lady's pocket-handkerchief at the end of a stick; the boat immediately bore down to our assistance, and towed us to the mouth of Douglas Bay. The crew were easily satisfied with a medium-sized silver piece, but had, besides, our hearty thanks and good wishes; ardent is gratitude immediately after the favour! Nothing daunted, we tried another haul at the mouth of the bay. The bottom of the sea was mostly corailine, and my dredge seemed to require a sharper scraper, which I got added to it, and the next time, having a lighter boat and good men and true, we met with tolerable success.

The next morning I emlarked in the Ellan 
Vannin, for a journey round the Calf. We coasted close to the cliffs of dark slaty rock, past several pretty headlands, bays and coves, Port Soderic, Greenwick, Santon, and St. Ann's Head. We next made St. Lawrence's Isle, with the dilapidated chapel of St. Mary upon it, supposed by Mr. Cumming to be an extremely ancient structure; then Long Ness, a lowish piece of land stretching out into the sea; thence we steered towards the Stack of Scarlet, a volcanic rock to the west of Castletown Bay; and after. passing the picturesque little Bay of Perwick and Fistard Head, with its cavern and pinnacled rocks, we approached Spanish Head, where the chasmed cliffs rise 300 feet perpendicularly from the sea. The channel between the mainland and the Calf is narrow and rough, with an island (Kitterland) in it, but nearer the main isle; and the course for the steamer is still more confined by a ridge of rocks. The currents which reach the Isle of Man from the north and south are divided at both its extremities; on the west side of the island the south current meets the opposed north one off Peel, after rushing violently through the straits westwards; on the east side of Man the two meet further north, off Ramsey. We had a fine Manx sailor at the hehm, and the captain was a noted and experienced man. On this occasion it was too rough to land; and the mists drove over the hills and rocks, obscuring the view, but adding wonderfully to its wildness. The nugatory result of my excursion obtained for me the banterings of my female friends upon my return, who asked me what I thought of the Calf of Man, with other withering insinuations, under which I succumbed not, but, to end matters, avowed that I had enjoyed the trip much, especially as the squally 
weather afforded me numerous views of the calf of the other portion of creation-there were ladies on board. I afterwards, on another day, landed at the little artificial inlet on the north side, and walked to the lighthouses. There is an enormous block of winte quartz with mica close to the landing-place. I was pleased to find the beautiful and rare orangedisked Actinia here in the crevices of the rocks, and upon taking in the anchor a fine specimen of that handsome Star-fish, Goniaster Templetoni, adhered to the chain, which I secured. The curious buttons of a sea-weed (Himanthalia lorea) covered these rocks, and I afterwards amused myself witl picking out, from a bunch of coralline, crustacea, shells, and annelides, which amounted to a considerable number of species. Birds of various kinds-petrels, gulls, Manx-puffins or shear-waters (different from the sea-parrot or puffin of Nortli Wales), pigeons, and other speciesabound, or did wbound, on the Calf; but now every steamer that touches has some miscreant gumner wlio wantonly attacks the birds, down even to the little stone-cliais. Geologically speaking, the islet appears to consist of Cambrian or old Silurian schist, witl basaltic veins, and some drift on the surface. The schist is a good deal covered with Stone-crop (Sedum). There is a curious story extant of a solitaire named Bushall, who once made this spot his retreat, and whose real history is remarkable enough. At the south-east of the Calf is a perforated rock called the Eye, and to the south are the Chickens, the lights of the two beacons being so disposed as to bear in a line upon them. 'Upon the accuracy with which these lights are kept depends the safety of many richly-freighted vessels, and the preservation of thousands of our hardy tars in the dark nights when the storiny winds do blow. And that solitary watcher, 
how deep the responsibility which devolves upon him to keep from sunset to sunrise the lights burning, the wicks well trimmed, the mirrors bright and burnished, and the machinery clean and regular, and wound up at stated seasons.'

On another day I landed at Castletown, and a walls of a mile and a half brought me down to Scarlet Point. The Strack of Scarlet is really, geologically speaking, a very remarkable object, of igneous formation; and numerous dykes, interesting to the geologist and mineralogist, are seen to course from it through the limestone in different places. On the shore great fossil Nautiii and Orthoceratites are seen on the surface of the lower dark limestone at ebb of ticle. Near the Stack itself was a little pool in which Brookweed (Samolus) and Hemlock-drop-wort (Enanthe crocata) were growing. Interesting specimens of rocks of great variety-felspar, basalt, trap, and tuff, \&c.--can be collected, but the fossils above mentioned are difficult enough to extract. A little nearer Poolvash, fossils of the upper grey mountain limestone, different from those alluded to ribove, goniatites and brachiopoda, are to be had, being unusually separable from their matrix. I was also shown a tooth of a plagiostome fish (Petalodus) from this place, conchoidal and curved apparently to the jaw, an inch and a half across, with a central cusp, but ill-marked, as well as the succeeding points on each side the centre. In the upper black limestone shale of Poolvash, I got Posidonia and the pelvis of a crinoid; and there are also traces of plants, some of which seem analogous to those of the regular coalmeasures. Some of the fossils from this shale are coated with bright metallic matter. In few words, there is a preponderance of zoophytes in the lower limestone, as seen on the west side of Castletown 
Bay and at Ronaldsway; of shells with trilobites in the grey limestone; and of cephalopodous remains and plants in the highest, the black shale or marble of Poolvash. Amongst the rocks, north-west of the Stack, are some curious pools at low water, and here I found sticking to their hollow sides numerous specimens of the little Star-fish (Asterias gibbosa), Mr. Forbes having previously found it here. The Uraster hispida has also been obtained. Many of the cottages seemed deserted or ruinous, perhaps from emigration and the failure of banks; a few kales and leeks grew in the gardens of others; the fields were weedy, and some flax was grown. Black rabbits were common in the warrens. Conger-eels and other frsh were drying at most cottages for winter use.

I took a peep at Castle Rusben, built in the tenth century by Godren, one of the Norwegian kings. I learnt that there were at that time but nine or ten lunatics under restraint here, and the castle contained all the poor lunatics of the island, none being sent out. Tt is remarkable that the same population in England now sends into confinement seven or eight times the number. However, I should add that, inquiring from a Manxman what they did with their lunatics, he said he could not tell, unless they drowned them, for he had heard of several jumping into the sea, or meeting their death in some such way. I noticed a Runic stone placed as a post at the corner of a street near the castle. I happened to irritate a Manx-girl by bidding for one of the tailless or rumpy kittens, as they are called, and refusing a glass with her to confirm the bargain, when she opened fire upon me, and her excited vituperations sounded very like the Irish brogue, and further convinced me that the Manx and Erse are first cousins. Rushen Abbey is but a moderate walk from 
Castletown, and was built by King Olave, in 1134; it is pleasantly situated, but not interesting architecturally. A white variety of Snap-dragon grew on the walls, and I noticed that every flower was perforated at the bottom of the corolla by the honey-bee to obtain the sweet secretion from the nectary. Whilst collectors of the farina push down the lower lip and take it out, the collectors of honey invariably either make, or use a little orifice already made in every flower. The dark red variety, however, seems to be perforated with difficulty, or not to yield the honey. We believe Mr. Darwin, noted for his observations of the wonderful treatment of flowers by bees, has noticed the same circumstance in other flowers. Returning to Douglas by sea, in the evening, its phosphorescence was very vivid, or rather the luminosity of particles in it, consisting in this case of Noctilucæ, scintillating in the eddy produced by the vessel, or on the summit of the breakers. Prettily, also, the lights shone on the shore as we passed along, and then there was a distant gleam ahead-surely rising out of the water; it became more distinct, and now I make out what it is - the light at our port; now it wares and grows dim; anon it gleams again in refulgent lustre. At Douglas there is a large quarry in the Cambrian or older Silurian grauwacké rock on the ascent to the lighthouse. I searched for traces of fossils, but found none, unless it were a few obscure marks of algæ. Others since have been more fortunate amongst these Manx slates. The common form of rock varies from a yellowish-brown or grey schistose stone to a clay slate or mica schist in the mountains; and granite or granitic rocks arise in dome-shape masses at two points - at the North Barrule and north of Laxey mines. I walked 
with a friend to Kirk Braddon, where, as is well known, are several fine Norse gravestones. There are some sections of the superficial boulder clay along the road. The sea doubtless once extended inwards in this direction for a considerable distance, as a caroe or boat was once found, and the Manx name for a flat field which is situated here expresses a harbour or haven. We searched the little river for a mile or more, for a variety of the pearl-mussel, Alasmodon Rossii, mentioned by Mr. Forbes as found here. I only satisfied myself that it existed by picking up a fragment of a valve. We next visited a druidical circle Glen Darragh, which we found with rather more fatigue and trouble than it deserved. It is one of the numerous remains of the original inhabitants, before their conversion by St. Patrick, whose landing is said to have taken place A.D. 444. We also visited two of the little cores or bays mentioned as seen from on board the Ellan Vannin, Port Soderic and Greenwick, the latter a sweet valley, with a comfortable house looking out seawards. Numerous boulders of granite and basalt lay on the surface above the bays, and the valleys presented sections of the recent glacial or aqueous deposits from which the boulders were derived. An earthen mound, called Cronk-na-maroo, is on the cliff above Greewick. Port Soleric is very romantic from its caverns, and it possesses a little hotel. In the carernous rocks grew the Gea-fern (Asplenium marinum), Scurvy-grass, Thrift, and some other plants.

The next day we formed a party and went from Douglas up the Baldwin Valley, following the Glas rivulet nearly to its source, between Garraghan and Greebah, and so across the island; some deep gullies and bogss separating us from Snafield and Ben-y-phot 
to our right. Unfortunately I was now no mountain climber, or should have mounted Snafield, which is about 2,000 feet ligh ; the mercury sinks two inches and one-tenth, says Camden, on its summit. Passing the water-shed of the island we rapidly descended. I led the party to Rennasse Waterfall, a sweet scene, when I left them and crossed over some hills to Peel, the most interesting spot, for tine antiquary at least, in the island.

On the islet at Peel is the cathedral church of the most ancient see in Great Britain, dedicated to St. Germanus. He was left bishop of the island in 4.47 by St. Patrick. The present ruinous building succeeded the first one, and was commenced by Simon the Bishop, under Norse rule, about 1226 . There is a venerable portion of the more ancient building remaining, called St. Patrick's church. There is also a Danish mound, and a round tower on the same plan as the Irish ones, in the castle area. A guard-house, and wall and towers, built under the Stanleys, constitute the remainder of the buildings, the totality commonly called the castle. The stories of Eleanor Cobham, of Fenella, of Christian, and of Moddey Dhoo, we leave for the guide-books to tell. From this spot the Irish sea is seen, apparently shut in by the Scotch and Irish coasts and by the promontories of the island, so as to look somewhat like one vast lake. I made rather a hasty ramble within the castle walls, and then scaled them and got upon the sea-girt rock on which the castle is built, having all the paraphernalia of a naturalist with me. The water was as clear as crystal; I could see to a great depth, and some of the holes at the foot of the shelving rocks looked formidable enough, the schist dipping rapidly north-west into the deep sea. Indeed I found the rocks rather awkward walking, and got 
one or two ugly falls, with little to reward me, except a fine lemon Doris from a cavern on the south side, and an equally fine crab, which I discovered at the very bottom of one of the clear but deep pools, and which, with bare arm and long stick and net, I could just reach. The castle is built of the ordinary Cambrian rock, but with facings of the Old Red Sandstone, which is found here, but apparently not very fossiliferous. The true Maiden-hair, Adiantum capillusveneris, undoubtedly grows at Glen-Meay, near Peel, but I did not get there; it is also said to do so at Santon rocks, and on the walls of the roofless chapel of St. Trimian, which I did visit, but without noticing it.

We got down to another part of the western coast from Kirk Michael, where it presents a long unbroken line of rocky shore, not very interesting. The village itself is remarkable for its Runic monuments, indicating 'that the persons to whose memory they were erected professed themselves Christians, which the more recent headstones might not perhaps lead us to conclude of the tenants of the graves beneath them.' Here, however, is the resting-place of the venerable Bishop Wilson. South of Peel, on the same side of the island, I visited Fleshrick Bay, a retired little nook, with lofty rocky hills on each side, on which were many sea-birds. Some fishing-boats were hauled up here, and the shore was strewed with objects of natural history of a curious descriptionskeletons of fish and birds, some of them fit for a museum, shells, crabs, and star-fish. There were vast quantities of the shells of three mollusca, all, I should suppose, of similar habits with respect to food, \&c.Buccinum undatum, Fusus Islandicus, and $F$. antiquus; and one would suppose that, on the Darwinian theory, they could not continue to live together, 
or must become assimilated. We passed a remarkable mound called Cronk-na-moor, covered with gorse and heath, and apparently intended as a place of defence, and then got to Port Erin, separated from Fleshwick Bay by Breda Head. We shortly walked to the copper-mines, at the foot of the promontory, by a path on the side of the steep declivity. These mines are well worth visiting from their grand situation. We got there specimens of ruby copper-ore. Senecio Saracenicus, the Tree Mallow, Inula, and some other old-fashioned plants were seen about the cottages. Some lanky, mouse-coloured sheep, called loughton, fed on the mountain, the mutton of which is very good, and mentioned as such by Camden, and the fleece makes a capital soft cloth, requiring (as fashion goes) no dye. I bought a coat, as well as seaside hose, made of the wool, which did good service. The bay at Port Erin is rather fine, and looked inviting for a stroll, but I (or rather I and mine) preferred a walk to a place called the Chasms, already alluded to as lying near Spanish Head, and overlooking the entrance to the strait. Before ascending the high ground two or three upright pillars formed of the slate of the headland may be noticed in the fields, probably memorial stones. We passed a deserted mine on the brow of the hill, where much galena lay scattered about-we supposed, from some impurity or other, valueless. The Chasms are ugly, but really wonderful fissures in the rock, of variable width, and, though we do not pretend to account for their origin, they may possibly be the result of a great earthquake recorded in the amnals of Wales, A.D. 684.* They run down from the upper surface of the headland to

* See Olirer's Monumenta. However, we should now be more disposed to explain them on the 'continuity' theory, at least in part. 
the junction of the land and water, or deeper, and must be very dangerous to unwary man or beast. Samphire and Sea-wormwood grow on the cliffs. Looking down from the Chasms we saw upon a little promontory rising from the sea a perfect druidical circle.

Another walk was along the eastern coast northwards, from Douglas. The valley of Onchan and its shore are close at hand, and worth exploring. Onchan possesses some fine Runic crosses, and at Lonan, further north, are others, and a Celtic antiquity called the Cloven Stones. I made the shore at a retired nook, in which was a fisherman's cottage, two miles on the Douglas side of Laxey, but did not find much, having little time to pass the rocks before the tide came up. Sedum Anglicum and Asplenium marinum were common on the walls. The coralline here abounded in minute shells, and each little animal of Kellia contained many still smaller ones. I mounted the coach, but left it near Ramsey, and walked across the country to Kirk St. Maughold, intéresting from its runes, and from the bold promontory, which also bears the name of the saint. The rock scenery here is grand; there is a celebrated well on the headland, considered to be medicinal, or at any rate curative. One cross at the church gates is of a different style from other Runic ones hard by, probably Scottish, of the thirteenth or fourteenth century, having the triquetra, or three conjoined legs, introduced, it is said, by that nation, but of the origin of which much has been written. One might suppose it was too classical an emblem for the Scotch of those days. A similar object formed the symbol of Sicily, and is found on its coins, and we have seen it on a coin with Phœnician inscriptions, found in 
Malta. A ship was the Norse symbol of the island. Castle Curry, or Chorry, is an eminence in the neighbourhood, with a stone circle upon it. Another fine Runic piliar besides those by the church is passed on the roadside before descending towards Ramsey. The grauwacké rock here passes into a kind of hæmatite or iron trap, and there is a little wharf and port at Lewaigne for the shipment of this ore, though now the trade seems stopped. A quantity of sand launces were drying near a cottage, with skate, congers, and other fish; we cooked one or two of the former, but found that their taste is not equal to their pretty silvery appearance. Further on, the seaward opening of Ballure glen is passed, and the botanist will be tempted to follow it up. Here I found the Osmunda higher than a man, and picked also $H y$ pericum Androscemum. We spent one very pleasant evening at a farm-house overlooking the town of Ramsey and its bay, and further north, towards the Point of Ayre, it was a sweet scene; the myrtles, fuchsias, lamels, Irish arbutus and hydrangeas were extremely fine in the open air. The host and owner of the estate was a fine specimen of a Manxman, hospitable, as his countrymen generally are; he had perhaps an habitual eye to profit; at least he asked our opinion with respect to a lump of quartz, with scales of yellow mica, which lay in his garden, and which he had brought down from the mountain, hoping it contained gold. We could but say that we were not experts, and that we had heard that all was not gold that glitters.

North of Ramsey the island is generally low and sandy, or peaty. The low lands are called the Curraghs, and in old maps lakes are delineated which then existed, but which now do not. Celts, coracles, and fir 
and oak-trees have been dug up in these places. It is here, also, that the remains of that noble animal, the extinct Irish Elk, or Megaceros, have been found, measuring seven or eight feet from the tip of one horn to that of the other. They occur in the fresh-water deposit under the peat, and two or three feet of this peat often exists covered by as many of gravel. The sea would seem to be making inroads on the western coast, whilst the Point of Ayre is, on the contrary, increasing; in fact the surface and coast-line in the north of the island have been much changed in listoric times; hence the accounts of the inroads of the Northmen, who commonly landed here, are in some cases sufficiently obscure. On the sands north of Ramsey we gathered numerous maritime plants.* Probably the island, and particularly this northern part, has not been well searched by the botanists. The geologist will be interested in a walk to Point Cranstal or Shellack, where the boulder clay, with its superincumbent gravel and sands, is well seen, and where the characteristic shells can be collected. The included boulders are of many varieties of rock; but we must recommend the reader to refer to Mr. Cumming's book for speculations on the origin of the superficial deposits in the island from water-flow or ice, the native source of the boulders, and the ancient connection of Mona with Cumberland and Scotland, as well as the status of the mountainous centre of the island, through countless ages, from the deposit of the Carboniferous strata to that of the Pleistocene. The late Pleistocene fossils of Point Cranstal are of numerous species, such as are now found in the neigl $l_{-}$

* Brassica Monensis, the Manx cabbagc; Glaux or Sea-millkwort; Crambe or Sea-kale; Cakile or Sea-rochet; the Tamarisk; and the Scamallow. 
bouring seas; some, however, more readily as fossils than recent.

The Manx Celts, who were probably the aborigines of the island, appear to have been pagans till converted by St. Patrick; and the cronks, stone circles, kistvaens, cairns, and barrows, numerous in the island, must commonly be attributed to them, though the Northmen who came next were also pagans, and raised other works. One or two of the Manx chiefs are on record, as Mannanan, ranking with our king Arthur. Harold the Fair-haired was the first of the Norwegian kings, towards the end of the ninth century; he was followed about thirty-two years after by another Northman, Gorry or Orrey, who organised the Tyndwald (still held on a mound between Douglas and Peel), and that Scandinavian form of government to which it appertains, and which is still the law of the island. In 1266, after a long possession by the kings of the seas, the island was ceded to Scotland, and after coming into the possession of various lords by right, might, gift, or sale, it fell in 14.06 to the fortune of the Stanleys. The Northmen seem soon to have become Christians, and the numerous Runic stones and crosses mark the resting-places of their great ones. The inscriptions are in ancient Norwegian, now, according to Camden, only spoken in the island of Tero; but the character is a little like the Greek, or, according to Mr. Cumming, like the Lycian or Coustantinopolitan. If the latter opinion is correct, it is curious to conjecture by what route the Nortlimen obtained their alphabet. The crosses appear to have been commenced to be erected in the middle of the tenth century, when probaluly the worship of Thor was changed for that of Christ. We have mentioned already several places where we 
noticed these stones, but should add that tiley are general throughout the island at the parish churches. There appears to be no good ground to suppose that the Romans ever had a footing here, wor is there extant any Manx inscription prior to the runes, though no doubt the first Cliristians, whether Celts or Norse, learnt the use of letters with their religion. Of the original Manx ecclesiastical buildings, there remain. numerous ruined chapels or oratcries, distinct from the parish churches, the latter instituted probably in later times under the Scandinavian dynasty; such ruins are St. Mirry's, St. Trinian's, and many others. Some of the crosses are extremely beautiful in their design, and in their complicated but elegant cable-work. Our own Danish crosses, found in village churchyards, are evidently erections of the same family.

The climate of the island is mild and equal, tlie summer heats being tempered by the sea-breezes, and the winter colds lessened from the vicinity of the surrounding warmer sea. Therefore the mean temperature $\left(48^{\circ}\right)$ is high for the latitude. The surface includes much waste land, and is commonly destitute of wood, but an eminent horticulturist informed me that he could grow almost anything on the island. The orchards are very productive, and the Manx apples famous; the fields too furnish fine crops of grain, but the agriculture is rather discreditable. At an agricultural dinner the president called upon a celebrated Scotch farmer to give the company his advice as to the best mode of cultivation for their fields. It was a very short speech:- 'Grow more corn and less weeds.' And truly we may find a good proportion of rank and outlandish weeds here. The potato, introIuced within the lifetime of some still living (1865), is grown laxgely, and is rery productive. 
Mona, as observed before, has an affinity with Ireland, in the physique and language of the inhabitants, also in the presence of turbaries, and their imbedded remains, including those of the gigantic Megaceros; somewhat in its botany, and in the absence of the mole, toad, and snake. The frog had in Camden's time, he says, been only introduced two years; and he adds that the magpie was imported, and that there are no woodpeckers, jays, or maups (?). The hedgehog is only known as introduced in quite recent times; the badger is absent; nor has the fox been found unless immediately imported; the weasel is common, but there are no otters, stoats, polecats, or martins. The grampus and the seal are seen occasionally, and the porpoise or herring-hog is common. The tailless cats are believed to have been imported by a wrecked vessel of the Spanish Armada, but the domestic fowl shows the same tendency to lose its caudal process and addenda.

Prof. E. Forbes used the dredge around the island, his native place, and found it very productive-off Ballaugh, for instance. I searched the shore well at Ramsey, and also the rocks near St. Maughold's Head, or rather I and mine did. Children are capital collectors when they are taught a little, the terriers of such sportsmen as the writer.* At Douglas I landed on Conaster, and picked beautiful living specimens of Troches Ziziphinus and Doris Argo. I got also specimens of a splendid Sabella (S. contortuplicata),

* We picked up (all of them in good condition, and many of them living) razor-shells, Solen ensis, siliqua, and marginalis, the last the rarest; Tellina crassa; Psammobia Ferroensis; Venus fasciata and striatula; Isocardia cor, a specimen with both valros still united; Cyprina Islandica; Astarte sulcata; Tapes rirginea and renea; Artemis lincta and exoleta; Lncinopsis undate; Mactra truncata and subtruncata; Littorina tenebrosa; Natica Montagui and monilifera. 
from the rocky pools in the bay below Castle Mona, and a friend found the curious Sea-hare in the same place. A beautiful bell-shaped medusa (Thaumantias pilosella) abounded in the bay, which I had not met with before. My dredging yielded me many molluses;* shells of Pectunculus came up by hundreds, and some of the old ones were worlds in themselves, being covered with parasites.t There were also some Eolides, beautiful creatures, crawling about, but for the Manx nudibranchs I must refer to Mr. Forbes's little book, or rather catalogue. The professor also found Eledone and Loligo, several Ascidiæ, and numerous shelled molluscs not mentioned above; many, for instance, adhering to the oysters dredged from the scallop and oyster-bed, which is situated off the north coast of the island. + Of crustacea, I myself found a few not common species.\$

I picked the prickly Saltwort (Salsola leali) and the Sea-purslane (Arenaria peploides) on the coast at Castletown and Douglas, and on the shore about the former place is abundance of Hemlock and Henbane, so that I was tempted to set up as a manufacturer of their medicinal forms. The mountains do not afford the alpine plants of Wales or Scotland, but Listera cordata and some of the Lycopodia are found. Arenaria verna occurs on the débris of mines. In damp

* Solecurtis candidus, Venus verrucosa, V. casina, Acmæa virginea, Chiton asellus, C. Iæris, Trophon clathratus, Trochus tumidus, T. Montagui, Mactra elliptica, Psammobia tellinella, Tellina incarnata.

$\dagger$ Ascidiæ, Tubulipora hispida, Cellepora, and Lepraria, Hydractinia echinata, Sertularia fallax, Jania corallina, and Plumularia falcata.

$\ddagger$ Emarginula fissura, Fissurella Græca, Capulus Hungaricus, and Velutina lærigata.

\& Pisa Gibbsii, corered with sponges and Eurynoma aspera. There were little shells of Trochus, with hermit-crabs occupying their carities, and the exterior enreloped with a thick cushion of Halichondria suberica. Another parasitical sponge was Isodictya fucorum. 
valleys amongst the hills are found some of the plants common in such places,* and the Curraghs yield many other interesting species, $\dagger$ besides a variety of molluscs. The sandy fields afford also their plants. $\neq$ On the beach at Ramsey are occasionally strewed fronds of Laminaria bulbosa of enormous size, with their inflated and tuberculated roots; likewise great specimens of L. saccharina and Alaria esculenta.\$

It is in the finny tribe that the island seems especially prolific, and blessed by a bountiful providence; so great a boon to the Manx that it may well justify the admission into the Litany of their prayer to 'continue the blessings of the sea.' In Douglas market a great variety of fish, some of them rare in other places, may be constantly seen. On one of our visits a shark (probably the blue shark) was exhibited by a fisherman as a curiosity, and from the showman I obtained a large frog-fish, for the dissection of its

* The bog St. John's-wort (Hypericum elodes), the lesser skull-cap (Scutellaria minor), the bog-pimpornol (Anagallis tenella), and Campanula hederacea.

$\dagger$ Mentha pulegium, Alisma ranunculoides, Hippuris, Contunculus, Pilularia, Cicuta virosa, Ranunculus lingua.

$\ddagger$ Linum augustifolium, Silene Anglica, Cerastium tetrandrum.

$\S$ I might give a long list of such Algæ as my young people brought to me. The following were distinguished and preserved:-Cystoseira ericoides, C. fæeniculosa, C. fibrosa, Dictyota dichotoma, Cladostephus rerticillatus, Chorda lomontaria, Haliseris polypodioides, Sphacelaria scoparia, Mesocladia glandulosa, Catenella opuntia, Laurencia pinnatifida, Conferva centralis, C. rupestris, Ceramium acanthonotum, C. fastigiatum, C. rubrum, Gigartina, Phyllopora rubens, Placomia coccinea, Delesseria hypoglossum, Malymene furculata, Polysiphonia elongella, P. byssoides, Chylocladia clavella, Microcladia. Bryopsis plumosa, Ptilota plumosa, and Chondrus crispus occur here as well as on the Welsh coast. I hare seen also Manx specimens of Delesseria alata, D. sinuosa, D. sanguinea, Griffthsia setacea, Ceramium ciliatum, Nitophyllum laceratum, Punctaria latifolia, Rhodomenia palmata, Gelidium corneum. 
curious structure. The shark had broken or severely injured the captain's leg by a blow from its tail. The voracious frog-fish swallows stones and goodsized pieces of rock; the accounts of its curious devices for entrapping other fish are no doubt veracious; they are well known. Numerous dog-fish or common topes are brought to shore by the herring fishermen, caught in their nets. I fancy the liaison of the sea-dog and herring is not an amicable one; though at a debate once, when the writer gave it as his opinion that the latter was pursued and devoured by the former, a great authority in the fishery question (a commissioner, we believe) doubted whether the dog-fish could catch a herring! I saw a picked dogfish taken from the stomach of a conger - a prickly dinner, one would think, not easy of digestion. The angel-fish is occasionally met with, also the sturgeon; the thornback and other skates are taken in plenty. Then there is the grey or common, and the red or rock cod, varieties of one species, the pollack, the green cod, the hake, and the ling. One of the same tribe called the gilpie, locally, is caught in immense quantities. The braize, the common seabream, gurnards,* and the common and red mullets, as well as several of the wrasse tribet occur, and are brought to marketat least, such as are worth it. The common mackerel is plentiful in its season, and the scad also occurs. To these may be added Spinachia vulgaris, weevers, blennies, gobies, cotti, and suckers, many of which we ourselves caught amongst the stones-a symptom of second childhood, perhaps! The lump-fish is not uncommon, and the short sun-fish has occurred. The halibut is rare on this coast. The æquoreal and

* Trigla hirundo, T. pini, T. lineatus and T. gurnardus.

$\uparrow$ Crenilabrus melops, Labrus lineatus, L. maculatus and L. pusillus. 
other pipe-fish, the armed bull-head, and the gemmeous dragonet occur. Perhaps the fish called killock, callag, or blockan by the fisherman, is the coal-fish; the bollan may be the ballan wrasse.

In the herring fishery, according to Cumming, more than 600 ressels and 4,000 persons have been employed in one year,* and more than $3,600,000$ square yards of netting. The take is usually from 30,000 to 60,000 barrels annually, each barrel containing 800 fish, therefore altogether making in the latter case $48,000,000$ herrings. The fleet of boats leares Douglas in the afternoon or evening, the fishing going on only at night. No lights or noises are allowed unless some steamer gets amongst the fleet, when the boatmen indicate the situation of their ressels by signals made by burning hemp dipped in some inflammable. The men are religious enough to offer a prayer before shooting their nets. A friend described the invitation from the captain to his men to worship, not as ' dearly beloved brethren,' but as ' now, comrades, let's have those two or three words,' which was followed by a short, silent prayer in the Jewish position, but with the face covered with the hat or cap. The nets are buoyed up near the surface by corks and inflated skins of dogs or sheep. Of course there are many miles of netting stretched out. The herring is capricious and uncertain in its appeurance, sometimes leaving places which it has frequented for many a year. One boat may be loaded, the next not take a single fish. The darkness of the night favours the fishing, and renders the brilliancy of the plosphorescence of these beautiful fish more visible; the bottom of the boat, covered with herrings, glows

* Dr. Cumming's book was published in 1848. 
with a living light. Dr. Landsborough, following Pennant, describes the herring as migratory from the northern seas; the idea is now generally scouted, and it is believed that the herring comes to the shore for spawning, and that it has made no longer journey than from the nearest deep sea. 


\section{CHAPTER IV.}

THE MOUNTAINS.

WheN one wends one's way through the Cheshire plain towards the coast of North Wales, or when, as oftener happens, one is whirled through it on the iron road, a few objects occur which may excite our interest. Those peat mosses or turbaries seem curious ; so much so did they appear to us, that we took an opportunity to examine one. They are generally perfect flats, with here and there great stacks of turf piled up for fuel, and in the one we examined were quantities of fir and other woods, and we picked up cones of the fir-tree, and hazel-nuts. A bed of sand commonly lies below the peat. Beeston Castle frowns nobly over the plain, and soon we saw the walls of Chester, constructed of what is, or was called, geologically speaking, 'New Red Sandstone,' though historically old enough. The Dee was coursing in the evening sun, and encircled the spot of sward which lies under the city walls, called the Rood-eye.

Arrived at the estuary of the river, sea-birds of several different sorts may be observed even from the train; sometimes the gannet or oyster-catcher, and frequently flocks of ring-plovers, dunlins, and terns. The Sea-starwort and Sea-holly may be noticed on the shore, also the Glass-wort, Salicornia, and the reed, Arundo phragmites, the latter used for thatching and other purposes; the Lucerne's showy fiower ornaments the embankments. Flint Castle is passed, once 
witness of the sorrows of captive royalty, only to be ended in those days by a heavier doom. Basingwerk Abbey can next be discerned, nearly concealed by trees; then the Vale of Clwyd is crossed, and in the distance may be seen the towers and ivied walls of Rhuddlan. A person of a retired turn of mind might pleasantly pass a few days at the little village of Colwyn, which we did once in early spring-time. One of our excursions thence was to the Little Ormeshead. After a sharp walk through the village of Llandrillo-yr-rhôs (a spot worth the antiquary's research, and near which is a rude and ancient little chapel in ruins, with a holy well, dedicated to St. Trillo), and by Gloddaeth, we attained the side of the declivity, and one little scene interested us much. We stood on some high ground declining towards the sea, apparently from the effect of a landslip; a little bay stretched inland towards our feet, with some huge masses of limestone partly blocking it up; against the gravelly shore of the cove the rising waves were beating, and further out the smooth sea, with several vessels passing, was seen, and noisy gulls and choughs above. We scrambled down over the ground covered with the common Thrift, but found little or no harvest to repay us for our trouble. As we returned to Colwyn, at low water, we found the shore in some places literally covered with star-fish, principally the common Uraster (rubens), but also the very beautiful Solaster papposa, with Cribella oculata, crimson and orange. Further out we found the beautiful Sagartia viduata or snakelock anemone. On this part of the coast they entrap fish by enclosing a space of ground between high and low water-mark with a wall of heavy boulders. Before coming, on the return, to the low marshy ground the rocks are very picturesque, reminding one of Derby- 
shire, being often cavernous and beautifully overgrown with ivy. Many of the plants, too, of this limestone district are identical with those of Derbyshire, as might be inferred by the botanist-with a maritime admixture however. The Little Ormeshead abounds with flowers and aromatic plants. The Geranium sanguineum is very showy; we gathered the yellow Figwort, or Scrophularia verna, in a hedge on the Llandudno side; Forster's Stone-crop (Sedum Forsterianum) and the Milk-vetch (Astragalus glycyphyllus) also grow here. The wild cabbage, Brassica oleracea, abounds on the rocks, and some plantlets of it transferred to the kitchen garden became luxuriant and capital borecoles.

On this visit to Colwyn, the days to be spared away from home were only two or three, but on one of them was a very low tide, not only because it was a day or two after the new moon at the vernal equinox, but because the sun and moon were also in perigee at the time. But, alas! I had equinoctial weather as well as tides, and experienced on one or two occasions discomfort enough to discourage any one but a desperate naturalist. Spring is much earlier on this coast than in the corresponding latitude in the centre of the island, though the mountains in the interior of Wales may be still covered with snow. The lucerne on the warmer sides of the sea-embankments forms a good crop, before the grass in mid-England is springing. In Llandudno Bay is a bank covered with fuci, and only laid bare at very low tides. I collected what I could, but the day was thoroughly wet and soaking as well as windy, and I was in a pitiable condition when I got to my inn at Colwyn at night, spite of umbrella and other defences; but my greatest trouble was to get off my wet boots, and I began to meditate going to bed in them. At last I called in a stout 
Welshman, and told him to pull, hooking my body round the banister of the stairs. He tugged, but in vain. I called for a glass of cwrw to renew his strength; another pull, but he shook his head and looked doubtfully. I told him a Welshman never gave in; he said he thought another half-pint of cwrw would do it, and another half-pint he had; and he came off, or rather the boot did, in triumph. I would not trust my legs in the boots again, but went out in pumps, and home in slippers.

Most people know Conway, its castle, walls, bridges, and old halls. The Alexanders (Smyrnium), Hemlock, and Broom Rape (Orobanche), spring up rankly in the deserted courts of the castle, and its walls are gay with the Wallflower, red Valerian, and Snap-dragon, the first a lighter tinted flower than its garden offspring, and the others of flowers of several shades, but, as is the case with flowers generally, their shades not running by graduated tints the one into the other. The thick-leaved Stone-crop (Sedum dasyphyllum), the Flix-weed (Sisymbrium sophia), and Dianthus caryophyllus also grow on the walls.

Many times have I enjoyed the walk along the shore from Conway, and from

The rock whoso haughty brow

Frowns o'er old Conway's foaming flood,

to Llandudno, even before the latter existed as a town. The plants which will interest a student in botany, met with in this walk, though not rare, are many - the Viper's Bugloss (Echium violaceum), the Hound's Tongue, with white flowers (Cynoglossum), the small Teasel (Dipsacus pilosus), the wild Sage (Salvia verbenacea), the Horned Poppy, the Gromwell (Lithospermum officinale), the Sea-holly, the handsome shore 
Bindweed, the fair evening Primrose, Sedum Anglicum, Torilis infesta, Henbane, Wormwood, Fennel, and the Nottingham Catchfly; the latter scented at night with a jasmine-like odour. Here vast quantities of mussels are raked to shore at low water, principally for food for man and swine, or for baits, but also for the pearls which they contain, and which are sold by the wretched collectors at about half-a-crown the ounce. The shell Tapes pullastra also inhabits the mussel-beds. These opaque pearls are not to be confounded with the totally different and often very valuable ones found in the fresh-water mussel (Alasmodon) higher up the river at Llanrwst and Bettws$y$-Coed. We flatter ourselves we set at rest, in dissecting both species of animal, the different opinions respecting the origin of pearls. They are due to the irritation caused by the presence, in the mantle or shell-secreting envelope of the animal, of a minute parasite, a Distonuus. Sometimes a little dark shelly matter like the exterior of the shell is first deposited, but with the Distomus within. Sometimes the parasite may be obtained with pearly plates adhering to it, or be seen within a thin covering of pearly matter, or extracted entire from the pearly case. Occasionally, however, a pearl may be less than the parasite, and sometimes pearly prominences are seen within the valves, especially towards the posterior extremities; these may be due to other less common causes of irritation, but especially to a parasitical mite $(A \operatorname{tax})$. On the Conway is a stake-net, but, as the meshes are large, little is caught to interest the naturalist, which is not the case at one or two other places on the Menai, where, in similar traps, we have procured interesting species-pipefish, sepiolæ, loligos, \&c., and where the hammer- 
shark has been taken. I got the little worm pipefish Syngnathus lumbriciformis, and noticed pieces of wood perforated by the crustacean, Limnoria terebrans. Several species of gull abound at the embouchure of the river, as the common, the herring, the lesser black-backed, the black-headed, and a few of the large black-backed gulls. Diganwy Castle, or rather the scanty remains of the tower and walls of this very ancient place, often mentioned in Welsh history, lie a little inward. I picked the pretty Maiden-pink (Dianthus deltoides) on the grassy hillocks. The path to Llandudno next leads across a sandy plain, which was somewhat melancholy towards sunset, from its desert look, and from the plaintive whistles of the plovers and curlews. The sand Lyme-grass (Elymus arenarius) and the Maran or sea mat-weed (Ammophila arenacea), grow in the sand, and help to bind it down. The Welsh cut and bleach the latter, and then form it into baskets, mats, and bee-hives; it is sharp as well as tough, as we learn by unpleasant experience, if we incautiously crop it. A little Rubus (dew-berry?) with a reflexed calyx, and glaucous berry of a few large grains, abounds in this waste, and bears copiously some years; the fruit is by no means despicable, either fresh or preserved. In the sun the scarlet and black burnet-moth flits about, and forms its cocoons on the stems of the mat-weed; the hawk-moth often hovers over the wild thyme, and the swallow-tail butterfly is occasionally seen. In the ditches I noticed the Water Violet and the Flowering Rush.

On one occasion we took a boat from Conway to visit the foot of the Great Ormeshead seawards. The excursion is not always desir $九$ ble, except in very calm weather, and who can always be sure of a continu- 
ance of that? The writer (he and his on this occasion) set off; the young ones thinking -

Fair laughs the morn, and soft the zephyr blows,

While proudly riding o'er the azuro realm

In gallant trim the gilded ressel goes ;

Youth on the prow, and pleasure at the helm.

But, alas! the other lines were to be illustrated-

Regardless of the sweeping whirlwind's sway

That hushed in grim repose expects his orening prey.

We cast anchor at the foot of the rock, and enjoyed the hauling up of codlings and gurnets, the latter displaying most beautiful rainbow tints when taken from the water. Some of the square stones, hanging loose in the face of the promontory, must be of enormous size, a hundred tons or more. A steamer and a brig came by as we were anchored, the former with music on board. We landed, and caught a good batch of crabs, poking them out of the fissures of the rocks. In the clear still inlets Medusidæ of several kinds and sizes were beautifully seen, and the green worm, Phyllodice viridis, was crawling upon the rocks. But we were now summoned by the two old boatmen, as it began to rain and blow. With less experienced boatmen we might have come to grief; and, as it was, had really much difficulty in getting back to Conway; we got amongst a flock of sunken rocks, the black fuci upon which we could see all around, besides having to wait long on the bar of the river for the rising of the tide. Opposite the little ruined chapel of Gogarth we for a long time could make no progress, but at last got into the river, and so to Conway, well drenched.

This Great Ormeshead is an interesting place, and repays exploration; there are several caverns on its face, one or two to the east, and another at Llech; the 
latter artificial, and of a half-octagonal form, with a seat all round, a font or basin at the door, with a supply of water, and a pillar for a table in the centre. Seals are occasionally but rarely seen on the boulders at the foot of the promontory; now-a-days the visitors scare everything away; porpoises are frequent further out. A pair of ravens, and another of peregrine falcons, constantly build on the rock. A few years ago, a friend was at the taking of the nest of the latter; it contained two fierce young ones, and the parents resented the injury with loud cries, and even at one time threatened by their swoops to knock the fowler off the narrow ledge of rock overlooking the sea, to which he had got without rope. One of these beautiful birds was not long since wantonly shot from a Russian musket, which the owner had brought from the Crimea. The young guillemot is believed to descend to the sea on its mother's back. Many other sea-birds inhabit this rock. Around the peninsula are terns and oyster-catchers, and we also saw two gannets or solan-geese on the stake-net in the straits; the three chats, wag-tails pied and yellow, and rock-larks, abound. An osprey was shot (1862) on Penmaen Mawr, the feet of which, from their firm and rough tubercles, seemed admirably adapted to hold the slippery fish. On the Ormeshead, as elsewhere, the swallow builds in the shafts of mines. We purchased the handsome eggs of the guillemots, of several gulls, and the dull white eggs of the cormorant and shag; but of late the trade of egg-gathering seems to have decreased, from the accidents which have occurred; women, however, sometimes venture upon the precipices. Under the west cliffs one may push on through the little sunny fields swarming with butterflies and other insects, and then sit down 
and watch the cormorants resting on the huge stones which are dislodged from above, and on which the waves dash wildly. An opera or pocket-glass well enables us to watch their piscatory feats.

Llandudno must now have been visited by a great number of people, and I need not describe it. The promontory or rocky peninsula of the Ormeshead on which its primitive church is situated is called the mountain by the visitors, though not entitled to that grandiloquent name. On its plateau is an interesting kistraen, and on a somewhat distinct eminence, Dinas, some remains of druidical circles, and I also there noticed traces of aboriginal houses. The cottages of the ancient Britons might have been built of alternate courses of turf and boulders, a common form of building in North Wales now, or of the wicker-work which we see in the South of the principality. From the mines on the top of Ormeshead I got, on one occasion, a good specimen of malachite, with several varieties of calc and pearl-spar, also one of the boulders used by the British as hammers and pounders. A horizontal shaft or tunnel may be followed a long way from the mine's mouth, to the neighbourhood of the telegraph; in the course of the passage there are some curious natural caverns, one gallery having, as they say, never been explored. Immense masses of fungus (Racodium?) occur in these mines, composed of a white or reddish thready structure. A human skeleton was not long since exhibited in the town obtained from a cavern on the headland, where also the bones of other animals occur; the skeleton is imbedded in stalactite, and in the crouching position, apparently as the person died; the cranial development good. Some unusual specimens of bone arrow-heads were shown with it; to us it appeared very ancient and interesting. I noticed a 
baby in an egg collector's cottage swathed in bandages, and took up a piece of their dark bread, thinking it to be a mineral. In some places about the headland are remarkable accumulations of shells, entirely of edible species, limpets, mussels, and periwinkles, and mixed with bones of sheep, therefore no doubt the remains of the meals of the aborigines. There used to be a great mound or midden of these as one turned the headland for Gogarth; lately I was not able to find it, and I suppose it has been removed from changes in the road.

There is now a path all round this promontory, certainly a magnificent walk; it is mostly on the face of the limestone rock, in which the strata are remarkably horizontal. On our perambulation we picked up various land shells, Cyclostoma, Bulimus, Pupa, Azeca, and Clausilia; fine lichens, too, and a few mosses, as Tortula tortuosa. A Machilis and Ligea oceanica were also common. In May the little spring Squill, Scilla verna, the Hoary Cistus, Helianthemum canum, and the Scurvy-grass, Cochlearia officinalis and Danica, adorn the turf; later in the year the Samphire, the Sea-lavender, Statice spathulata, and the Sea-kale, Crambe maritima, may be gathered. The Madwort (Asperula procumbens) is found at one point (Llech), but it is difficult to crop. A botanical friend told me that he got to it, and had it nearly within his grasp, when the thought of his dangerous position, and of his wife and seven children down at the Plas Penrhyn, flashed across his mind, and he gave up the final stretch to pluck it. Many rare plants were gathered by us from the rocks above the town, ${ }^{*}$ and in the

* The Cotoneaster, Chrysocoma, Barkhausia, Veronica hybrida, Hutchinsia, 'Thalictrum minus, Spiræa filipendula, Gymnadenia conopsea, Gnaphalium dioicum, and Juniperus nanus. 
immediate vicinity many others.* A walk, too, on the west shore, past the ruins of Gogarth, will repay the trouble, as many more plants will be found.t On the exposed part of the Great Ormeshead, plants are wonderfully stunted. I lately asked a friend, to whom I am indebted for some other scraps of observation recorded in this chapter, to use his eyes once more for me during a short visit to Llandudno. He brought me, as the result, Helminthia echioides, Trifolium fragifcrum, an Allium, and Potamogeton trichoides. He points out that the capsules of Lychnis often contain a large caterpillar rolled up, one in each capsule (Actena capsulicola); such capsules may be distinguished by a small hole, by which the egg has been admitted. There are also numerous spiders (Agilena labyrinitica), which form beautiful webs on the dew-berry, about a foot across, with a tubular prolongation towards the ground, itself subdivided into two or three other tubes; and a small stinging bee abounds on the promontory, forming its nest in a lole in the ground. Such a friend as the above is worth employing, but our expectations of this kind are sometimes doomed to disappointment. For instance, a gentleman once told me he was going to cross Snowdon: what should he get me? 'Bring me all the mosses you can collect,' said I. ' I will.' And soon I received from him a large hamper by coach ; for it was in coaching days, and the carriage cost a good sum. I unpacked it, and found not a single moss; but dried-up thyme, withered ferns, ling, leaves, lichens, and such like. He must have grabbed right

* Orchis fusca, Lithospermum maritimum, and Raphanus maritimus.

+ An Orobanche apparently parasitical on the iry, Anthyllis, Hippocrepis, Paparer hybridum, Modicign maculata, Erodium maritimum, Cakile, Beta, Potentilla verna, Hypericum montanum, the handsome chicory, and many others. 
and left, and what his idea of a moss can have been was best known to himself.

The writer has had many rambles at low water at the foot of the Great and Little Ormesheads, as rrell as at the mouth of the Conway River, and has several times dredged in Llandudno Bay. The dredging was an early atteinpt, and the instrument did not sink well till we shaved off some of the wood and added more iron; but especially our course was at first too rapid, as the boatnan would put up a sail. The consequences were that the dredge required too much rope, and drifted far behind, and as it sometimes got fast the sail had to be taken in quickly. If the boat is going so rapidly, moreover, the dredge buinps upon the bottom. We, however, took molluses, radiata, zoophytes, \&c., and crustacea enough to satisfy beginners in dredging.* Between ligh and low water-mark, under the Ormesheads and in the intervening bay, we have found several species of Doris, the large lemon-coloured one and others, as well as species of Eolis and Chitons, by turning up the stones. $\dagger$ Hiatella rugosa burrows in the limestone, and Sphenia Binghami was met with. Specimens of Solen or razor-shell may be taken in the bay at the equinoctial tides.t Several of the rarer Actiniæ were

* Philine aperta, Corbula, and Nucula anongst the molluses; Opliura rosula and albida and Echinus esculentus (rery large) bolonging to the radiata; Eudendrum ramosum, Tubularia indirisa, Flustra truncata, F. Murrayana, Alcyonidium parasiticum, and Antennularia ramosa of the zoophytes, \&c., and Corystes Cassirclaunus, Stonorynchus phalangium, Hyas coarctatusand aranous, crustaceans.

+ Doris argo, D. Johnstoni, D. aspora, D. bilamellata, Eolis papillosa, another with rermilion-tipped branchiæ, and sevoral small species, Chiton fascicularis, C. cineroa.

† Other bivalres were Mactra stultorum and solida, Venus striatula; the Solens, were ensis and legumen (and dellucidus?) 
found by us, but may probably be now scarcer.** Ophiura bellis is common under the Little Ormeshead, where there is much sand mixed with the boulders. The little crab, Porcellana platycheles, and occasionally the $P$. longicornis, are to be found under the stones. $\dagger$ Amongst annelides myself or friends obtained two or three species of fine Sabellæ as well as other genera; $\ddagger$ then there were sponges to be peeled off the rocks or which were brought up by the dredge, $\S$ and a fer ascidians. $\|$ At the mouth of the Conway there is a shell-drift to be met with, containing many species, particularly minute ones. 1 I found two specimens of the little fisln, the argentine, at the foot of the Great Ormeshead; the small spotted dog-fish and the frog-fish were cast on the shore; the spotted gunnel, the bimaculated sucker (a curious tadpole-like little creature), the stickleback, the gar-pike (notable for its green bones), launces, shannies, gobies, and blennies came urder our notice. The rare and beautiful opah was once caught in the bay.

It is a fine walk from Conway towards Caernarvon, the geology being displayed in several sections of road and railway; the rocks and mountains to the left, and the sea to the right; further on, pretty

* Actinia troglodytes, A. dianthus, A. bellis, A. rosea, and Anthea coreus.

† Other crustaceans, Pilumnus hirtellus, Portunus puber, Pycnogonia, Idotea, \&c.

† Pectinaria Bolgica, Sabellaria alreolata, Polynoe, Nemertes Borlasii,

$\S$ Halichondria panicea, Mymeniacidon sanguinoa, Desmacidon fruticosa, coalita, and ramosa; Grantia compressa, and Spongia pulchella.

$\|$ Botryllus polycychus on the Laminuria, Polyclinmm, Amoroucium Cynthia grossularia, and others.

- Fissurella Greca; Lmarginula rosea and reticulata; Lucina rincta; Rissoa rentosa, parva, and crenulata; Mangelia costata; Trophon muricatus; Terebra tubercularis; Odostoma obliqua and Rissoida. 
inland scenery, and then the Menai with the bridges and the opposite coast of Anglesea; all charming! From Penmaen Mawr large quantities of grey basalt are shipped for road-stuff and paving-stones for the Midland Counties. Upon starting from Conway the 'collector of simples' will notice the Vervain and wild Madder about the town walls, and furtler on the Eryngo grows, as well as the pretty Campanula hederacea. By talking the valley to the left, before Penmaen Mawr is reached, a pleasant détour between the hills will lead again to Conway, and in this walk Scutellaria minor and other plants of springy, hilly spots will be gathered, and some druidical circles on the hillside may be made out from the road. On the coast here one may pick up large living Modiolæ, often with Chitons attached to them ; most of them had also specimens of the pea-crab within, as have some of the large Mytili from this coast; many other shells are also found, but principally on the Anglesea side, for the other is less productive.* Near Beaumaris, towards Puffin Island, is one of the best places for marine animals in the straits, and an interesting paper has lately been published on a very remarkable annelide, Choetopterus insignis, found there at low water. It inhabits a tube concealed in the sand, and another parasite is invariably found in the same tube, Lepidonotus cirratus. Edwardsia is also found on this part of the coast. I got one trophy on the Conway side, which I put in my pocket--a goodsized crab. My bedroom that night was at the hotel, not far from Conway Castle, and I went

* Lutraria hyans, Mya truncata, Pholas papyracea, P crispata, P. candida, P. dactylus, Scrobicularia, Nactra cinerea, Tellina fabula, T. tenuis, Solen siliqua, Cypræa, Psammobia Ferroensis;, Aporrhais, Dentalium. 
soundly to sleep when I retired to it. Towards midnight I awoke rather nervous, having dreamt about being imprisoned in some castle, and that in a neighbouring cell some one was effecting his escape by working with a nail on the masonry. I sate up, and did hear a scratching on the floor, and after some time referred it not to the rats, but to the forgotten crab, which had made its escape. To secure sleep I arose, and, after a hunt in the dark, caught the creature; but how was he to be secured? I thought it best to invert the water-basin over him, expecting he would be quiet. I got into bed, but the same scratching began again, with the pleasant addition of the scraping of the locomotive basin. Up again, and having seized the creature, I meditated drowning him in the ewer of fresh water; but of the quick effect of that I was doubtful, and, besides, am not cruel by nature, particularly to crustaceans, which appear to be a generation of considerable intelligence; at any rate they use their claws in a very human-like inode. I shrunk from the foul midnight murder, and hit upon a better plan to insure quiet. I had warm woollen stockings, and I put him in the leg of one of them, and, wrapping him well round about, I again committed him to the floor, and heard no more of him.

The portion of the straits situate between the two beautiful iron bridges, besides having the attractions of those wonderful works of art, are picturesque and peculiar in their scenery, from the number of rocks and small islets. The tides and currents run so rapidly as to render the place rather treacherous to the shore-hunter, unless he gives heed. The shore abounds in a fine mud, in which some marine creatures delight, as crustacea and annelides, Nemertes 
Borlasii, for instance; Sagartia troglodytes and Bunodes crassicornis; whilst not a single Actinia mesembryanthemum is to be seen, it evidently preferring clear water. I picked Tethya spherica, Halichondria hispida, and Dictyocylindrus incrustans, Grantia nivea, \&c., Tubularia indivisa, and some fine Sabellæ. Eolis papillosa occur's of large size, and the pretty living cowrie. On one of the small islands on the Anglesea side is an ancient chapel and a cemetery.

Before penetrating into the interior of Snowdonia, we passed the Menai and explored some portion of Anglesea. Beaumaris is a good locality for plants, several little littoral varieties, insignificant in appearance however, being met with about the town. On the hills above, from which there is a splendid panorama of Snowdonia, we gathered, near a little lake, the tall Broomrape, Orobanche elatior. Samolus Valerandi, and the pretty Bog Pimpernel, Crambe maritima, and other sea-plants may also be obtained, along the coast towards Puffin Island, particularly at a little gravelly bay. The Alexanders (Smyrnium) abound on the island itself, so as to be a nuisance to the collector. As may be inferred from its name, this islet is frequented in summer by puffins, which deposit their single whitish egg in the rabbit holes. Camden says the old birds fish all day, and return in the evening and disgorge the food for the young, in whose stomach only oil and leaves of sorrel are to be found; these are very fat, and fly about August 15. I found Anthea cereus on the rocks near the Lighthouse, and Actinia bellis and dianthus nearer Beaumaris. I noticed a specimen of Rhizostoma Cuvieri in the straits, a vast medusa; also Beroe and Cyanoea aurita, purpurea, and capillata.

We struck across the extremity of Anglesea to the coast, passing Penmon Priory and another ruin. It 
was a wild spot where we came down to the sea, with a copper-mine upon the headland above; the waves were dashing in upon the cavermous rocks, and we here got some plants, with a luxuriant fern, Asplenium marinum, and also some sea-weeds.* On another occasion we came down upon the shore at Red Wharf Bay, and got abundance of the interesting Bulla lignaria, with some other shells of such sandy bays. $\dagger$ We walked onwards along the shore to a spot where an event in a few months happened which was far enough from our thoughts at the time-the loss of the Royal Charter. The mountain limestone comes to the surface here, and the environs of the bay abound in plants. On the road from Beaumaris the traveller passes over a rock, more compact and bluish than at other places, and traversed with large veins.

Another excursion was to Holy Island. Here I walked some miles along its western coast to the South Stack Lighthouse-a grand and sublime scene, which we wish we could well describe. The structure is built on a steep rock hollowed by great caverns, and connected to the perpendicular rocks of the mainland by a suspension bridge. The sea-birds, gulls, guillemots, razor-bills, and cormorants, are not molested here, and consequently are very tame; they serve to warn the sailors off the rocks in foggy weather. The varying plumage of the herring and other gulls may, on account of this tameness, be here well studied.

* Halidrys siliquosa, Codium tomentosum, \&c. We also met with the following on the Anglesea coast, besides others found also at the Isle of Man :-Dasya coccinea, Calithamnium pedicellatum, Ptilota sericea, Rhodomela scorpioides, Conferra albida, Ceramium diaphanum, Gigartina. mamillosa, Asperococcus, Rhodomenia ciliata.

t Mya arenaria, the protty Tornatella fisciata, Tapes decussuta and pullastra, Artemis lincta, and a small form of Cyprina Islandica (?) Further north the rocks on this coast abound in Sagartia nivea, S. venusta, and $\mathrm{S}$. miniata. 
All the coast appears to be of the same chloritic slate, not very laminar; the strata often perpendicular or tortuous, with here and there deep gullies or inlets leading inland-remarkable spots. Fragments of wreck were strewn about. In this walk I passed, after leaving Holyhead, the Trefigneth cromlechs, or kistvaens, three in number, and struck the shore near to a hillock of sand, Towyn-y-Capel. Many human skeletons and skulls have been here from time to time exposed on the face of this hill, which has been worn down by the sea, and the turf on my visit was strewed with bones, so that probably a perfect skeleton might in a little time have been built up from them. The Sea-spurge grew about. On a heath I relieved a suffering beast, in the shape of a horse, from a dilemma in which it had got, having threaded with its neck a gate, carried it from its hinges, and wildly borne it about till it was spent, whilst the rest of the troop were collected around, reminding one of the print of Mazeppa. It had the sense to allow me to approach it and relieve it of its burden, which I did with some pains, when it galloped off without showing any signs of recognition. Holyhead, though it has great works going on, is not what a Napoleon would have made of such a town, the great exit, as it is, to the sister isle. The church, however (dedicated to St. Cybi), is well worth an antiquary's visit. Several rare plants are to be met with along the coast-the spotted rock, Cistus Helianthemum guttatum, Limbarda, Diotis, and the Portland spurge, Euphorbia Portlandica.

At Caernarvon the castle is of course the principal attraction. The hydrangeas flourish here in the gardens in great beauty. Twt-hill, near the town, commands a fine view. Targiona hypophylla and 
Gymnostomum Wilsonii grow here. I crossed the straits by the ferry-boat, and wandered on the sands on the opposite side, where a variety of strata, as limestone and the Old Red Sandstone, come to the surface, and where there are some quarries that show them. I also walked to the remains of a Roman wall near the town, formed of rough stone and mortar, making a masonry as hard as the solid rock, as a labourer told me, who happened to be using the pick at the foundation. Sedum dasyphyllum grew upon it. There is a museum in the town, and many of the objects were obtained in digging here, it being the site of the Roman station, Segontium; there was, amongst others, a fillet of pure gold, probably Basilidean, or used as an Essenic or Gnostic amulet, and having the mystic devices and inscriptions usual on such objects. At a shop opposite the castle may be obtained rock crystals, small bits of malachite, and spars from Snowdon and the Great Ormeshead; also Welsh music, portraits, photographs, and dolls.

From Caernarvon, we followed the coast to Clynog, at a little distance from the shore, crossing several fine streams, having Snowdonia and the Rivals before, and leaving the rocky shore of Anglesea to the right and behind, white with the sea-surge, and bright in the sunshine. We arrived at the village, which, besides its picturesque and rural appearance, had numerous Celtic remains in the neighbourhood; the inn, however, not quite comme il faut. Our window looked upon a very fine old church, dedicated to St. Tudno, of transomed Gothic architecture, with a transept and side chapel, the latter dedicated to St. Bruno, the uncle of Winefride. The lich-gate was remarkably rude, and seemingly very ancient. There is a holy well above the village, surrounded 
by a wall and stone seat; also some fine waterfalls in the mountains, but I was not strong enough to face the latter, and only strolled along the shore. Patella lcevis and translucens, with Trochus umbilicatus and crassus, were common forms here. I measured some Welshmen's heads with tape and calipers, and can say nothing against their capacity, as some were bigger than my own. Whilst doing so they must have thought me Merlin redivivus, or some such conjuror, for they looked with a good deal of suspicion upon me, notwithstanding all my gentle moral suasion, backed by the parson and clerk; and one big fellow, a cordwainer, oozed at every pore. The next morming we were off at five o'clock by the mail for the Bay of Cardigan. In the early dawn the fields were beautiful ; four in hand was exhilarating; the fogs rolled over the hills, and, as we proceeded, the early milkers were in the fields, and there was a heap of luxuriant fodder under each cow's nose. We left the two hills called the Rivals to our right, forming a promontory of this part of North Wales. We fancy they are not often explored; but one friend, already alluded to, often used to ramble upon them, and sent us specimens which were there gathered. It was against my will to miss them, but I was not able to go.

We arrived at Pwllheli to breakfast, and it was market-day. The women wore high hats and shawls and full-bordered caps, and were, besides, very substantially dressed. Many seemed both old and tough, as well as withered and brown with the mountain air and sun. There were few individuals of a blonde or xanthine complexion, the eyes being brown, and the hair the same. The waves came in very finely on the shore, notwithstanding the day was calm. The har- 
bour is separated from the sea by a spit of land, and has a narrow entrance, and a huge rock rises at the extremity of the spit, called the Gimlet. I found a handsome sponge on the shore, and on the rock $A s$ terias hispida. I also picked up Trochus Magus of large size. Roccella grew on the rocks, and on the shore I gathered Euphorbia Paralia, Cochlearia offcinalis, and the Sea Bindweed. There were some caverns in the Gimlet, and a pretty silky willow (Salix argentea) grew upon it. The Welsh are difficult to move. In vain I tried by love or money to induce the fishermen to assist us, hoping to procure some of the rarities, Venus Chione, for instance, which the bay affords. Some Welsh song-books, vocabularies, Bibles, and so on, were in the bookseller's window opposite our lodgings, and I went in to buy; but the possession of such books was denied by the shopkeeper till actually taken from his own window. I took a lesson in the pronunciation of the word Pwllheli, but with indifferent success. I found that I must blow out from the sides of the mouth in the direction of a cat's whiskers, whilst I applied my tongue to the front teeth. For myself to accomplish it properly I must have had my upper bicuspids extracted, besides making an unpleasant splutter.

One day we set out with a supply of execrable Welsh cheese, tough as caoutchouc, and cut from a whole one so curious in shape that I took a drawing of it; also with a few hard sea-biscuits. We took our way along the shore, westward. A glorious day, and an unrivalled view, over the Bay of Cardigan, of the whole range of the Welsh mountains-the Rivals, Snowdon, Cader Idris, and Plinlimmon-rewarded our exertions and made amends for poor fare. We came to a lovely village and church 
(Llanbedrog), situated in a woody and retired nook at the foot of a steep hill, a sunny and peaceful spot. The scene, and the Gothic window of the church, tempted myself and companion to advance, when we were surprised with the sound of a Welsh hymn on the other side, where we found that they were interring a young woman who had been in service in Liverpool, ' taken cold,' and come home to her native hills to die. Beyond the village a high promontory and two or three islets (St. Tudwall's) were seen on the margin of the sea. My companion had a very slight recollection of having been in her childhood at Pwllheli before, and particularly of its beach ; and now the landscape, the churchyard, the church, and other objects around, began to dawn as old acquaintances upon her memory. Upon enquiring the name of the squire of the place, and of the house near, a visit there was recollected. Passing another village, having a bay and tower of some sort, we crossed to the other side of the promontory, following up a very curious hollow road. We stopped at one place to look at a mine of black ironstone, and a hideous chasm it was. We next passed Llangean, with a fine churck and school, approaching the wild and sandy shore at a place with an ugly name-the Hell's Mouth-below Lilaneagan, a wild and dismal spot. In the ditches were a rare Alisma and Juncus acutus. The cottages or huts were clean and neat, the approach to the upper rooms being by ladders. No one could speak a word of English. Arrived at the shore, we saw, at a little distance from the shore to the right, Bardsey Island, once the seat of learning and piety, also Aberdaron on the mainland, whilst to the left great rocks jutted into the sea. The shore seemed most fertile in Algæ, but there were also objects of the animal kingdom to interest; 
the Anthea of unusual beauty, Naticæ and their curious niditamenta, ${ }^{*}$ with a variety of limpet covered with Chorda filum. To the lover of the wild in nature, and to the investigator of primeval and later antiquities, this locality would apparently yield well.

A ride of ten or twelve miles along the coast from Pwllheli, past Criccieth, brought us to Tremadoc. The hedges were adorned with a pink variety of the hedge Convolvulus. When we arrived at the last place we took a stroll on the cliff to the right, along what we supposed to be a public walk. There was a spider with a beautiful web which we discovered on the rock, and I very ill-naturedly dropped a bit of twig into the network. The creature first came out to recomnoitre, and then endeavoured to get rid of the intruder by giving the delicate fabric several good succussions; these being without effect, he came again and fairly kicked it out of its domicile. From a common at the end of the walk was a beautiful view of a valley leading towards Bethgelert, with mountains on each side, our road being in that direction; further on was the opening of the valley towards Festiniog, and beyond lay Harlech. Below us, amongst the rocks, were some young Nereids sporting in the water and sunshine, with dripping hair. We sat down to survey the scene, including the Nereids (a lady was of our party), but were disturbed by several snakes; we might have supposed that Nereids and snakes go together; the latter, at any rate, seem plentiful in this district. Here is an interesting station for the geologist, for fossil crustaceans, algæ,

* These horse-shoe, or rather horse-hoof-like bodies hare been supposed, or rather something analogous to them has been supposed, to have given rise to the similar-shaped markings soen on some sandstones. Such markings as oceur in the Millstone Grit might be due to hollow and reed-like plants, such as calanites, inclined by the winds, and, when
decayed, covered with sand. 
and brachiopoda are found in the slate which is shipped here, it being of almost the oldest fossiliferous date.

Hence we had an ascent up a valley, with precipitous rocks and cairned mountains on the left, and some meadows and the river or Traeth Mawr to the right, towards Bethgelert, coining first, however, to Pont Aberglaslyn, but finally stopping at the firstnamed sweet spot. The salmon freely ascend the river just mentioned, and formerly there was a celebrated salmon-leap near the bridge. From Bethgelert I had two or three walks; one to Llyn Cwellyn and Bettws Garmon; here I picked Asplenium lanceolatum, Bryum elongatum, and the rock parsley (Cryptogamma), also Cinanthe crocata and the marsh pea (Lathyrus palustris); another was to the bold rock Dinas Emrys, on the Capel Curig road; and another through the woods, some of which appeared to be the remains of the ancient forest of Snowdon. The Spignel (Meum athamanticum) grows by Dinas, and Sirm verticillatum, Hieracium paludosum, Carzx binervis, Bartramia arcuata, and Anictangium imberbe also occur. The well-known, so-called grave of Gelert appears to us to be a British kistvaen, andthere is a mound like a barrow hard by.

We proceeded to Llanberris, the road leading past the southern spur of Snowdon, with a river and a lake, Llyn Dinas, in the deep valley to the right. The mountains were ribbed with great white veins of quartz. Up a gorge to the left, called Cwm-y-llan, we had a fine riew of Snowdon, and the mountain may be ascended this way. Llyn Gwynant is next passed, and we found a curious hemipterous insect (Salda riparia) on its shore. The lake passed, the road is joined by that from Capel Curig to Llanberris, 
but our way was to the latter place orer the eastern spur of the mountain, where a cascade is seen to fall from the torrent coming from $\mathrm{Cwm}$ dyli and its lakes. We were soon in the pass of Llanberris, but the evening was coming on dark and gloomy with rain. As we got lower, the clouds, as well as the darkness and rain, increased; but a pretty suggestive object struck us-the evening star in the yet remaining clear sky at the top of the pass. Shortly we passed the village and the Dolbadern Tower, when soon the gaily-lit Victoria Hotel was at hand. We found Lobelia and Littorella easily enough in the water between the upper and lower lakes. The Awlwort (Subularia) and Quillwort (Isoetes) are found in deeper water in the lower lake opposite Dolbadern Hotel, but a boat and boat-hook were necessary to get there, which, however, were willingly lent. We afterwards grew them all in gravel with spring-water. Alisma natans came up with them, and flowered, as did the Subularia and Lobelia. We also got Sparganum natans, and on the stones were a fresh-water sponge and a little Ancylus, or fresh-water limpet. Many other rarities of Flora are to be found about Llanberris and Dolbadern.* Some old-fashioned plants may also be noticed about the cottages deserving a record, though they may not be truly wild - the Tree Mallow, the Sweet Cicely (Myrrhis), Elecampane (Inula), Alpinc Comfrey (Synphytum tuberosum), and the Masterwort (Imperatoria). Dolbudern tower seems a good place to station oneself for the capture of insects. On this occasion our stay at Llanberris lasted a week, and we were pretty successful in that department. The naturalist should always carry a little

* Polygonum viviparum, Schænus alba, Galium boroalo, Papaver Cambrica, Epipactis ensifolia, Habenaria albida, and Malaxis paludosa. 
phial of spirit with him, in which to pop beetles, \&c., when he meets with them, and if he picks any up in Snowdonia there is a chance of their being rare. Carabus glabratus, Chrysomela cerealis, Leisterus montanus, and Byrrhus alpinus are found here, and a new Colymbetes has been discovered in the Snowdon lakes.* It may be remarked that a very slight inspection of the sides of the mountains will make it clear that the rocks here, to a certain extent above, are worn down and rounded, whilst higher up they are sharp and angular; a phenomenon due, we suppose, to glacial action.

The charr, or torgoch, is found in the Llanberris lakes as well as in Llyn Cwellyn. I have nowhere heard the cuclioo so sweetly as in the woods at the foot of Snowdon. The ring-ousel is conmon, and is called the Nwyalchan-y-craig, or rock-ousel; there is reason to suppose that the dottrel breeds on the mountain side; the merlin is common; the sea-lark or rimg-plover frequents the lakes in summer, with sand-pipers and the water-ousel.

The ascent of Snowdon is comparatively easy from Llanberris. Having had the course of the road pointed out from the fields above the waterfall Cannant Mawr, a stranger might easily in fine weather find his way. Several persons, however, have been killed by missing the roads in fogs, and more than one pedestrian has died from sheer exhaustion. On one precipice, a continuation of Moel-y-cynghorion, a large lump of quartz marks the spot where the body of one unfortunate excursionist was found, and Williams, the guide who placed the memorial there (having discovered the remains after they

* Soe Christy, notice of a Tour through North Wales, \&c., Loudon's Mag. vol. ri. 
had found a resting-place unknown for the winter months), afterwards met with his death whilst collecting plants on Clogwyn dur Arddu, a celebrated botanical ground above the small lake Llyn du, seen to the right on ascending from Llanberris. The writer confesses to having made the ascent of Snowdon on horseback. On the Llanberris path there are two grand views; one on the right, with the dark lake just referred to lying in a deep hollow, the other to the left, from the Crib y ddysgyl over Cwm glas and the pass of Llanberris. From the summit, called in Welsh Wyddfa, the other approaches may be traced, one being from Bethgelert by Llechog, and the sharp ridge Bwylch y man; another from Capel Curig, by the lakes Llydan and Glaslyn, the fincle looking zigzag and difficult enough, with Lliwadd to the left and Crib goch to the right; one has already been mentioned from Llyn Dinas, the path being also traceable from Wyddfa; whilst there is another from Llyn Cwellyn and Bettws Garmon by Clogwyn dur Arddu. The views are interesting in the direction of all these roads; whilst, further off, lake after lake, the Straits of Menai, Anglesea, the Bay of Cardigan, and the Isle of Man, with mountain upon mountain all around, form the views. These mountains are to the right as one faces the south Mynydd Mawr, rising over Llyn Cwellyn, and others further off, as the Rivals; Moel Hebog above Bethgelert; Moelwyn to the south; Moel Siabod above Capel Curig; the Glyders to the left, and, further off, on the same side, the mountainous region beyond the Ogwen valley. Roberts of Dolbadern is one of those useful men who will accompany any botanist, and in a short time find more of the rare plants than a stranger could in a much longer period. 
The botanist should choose such guides, and also select the less common ascents if he can manage them, be on foot if he be a good pedestrian, and hare a long. day before him. Fossil impressions of the Caradoc formation may be knocked out of the schists at the summit, and rocks of an igneous character are seen immediately on starting on the Llanberris ascenthere hard green-stone, in other places approaching pumice or volcanic ash. The huts at the top of Snowdon are miserable places-two rival establishments, abounding in fleas. There were many attempts at wit in the books in which visitors inscribe their name; one party had not been fortunate in the day-they 'viewed the mist, but missed the view.' On our ascent, early in May-almost the first that had been made that season-there was not a cloud in the heavens. The botanist will probably fail to get several of the rare Snowdon plants which he may expect to meet with,* but there are many which he ought to find. $t$ In the rivers, rills, and pools or wells on and about Snowdon may be found other regetable forms interesting to the microscopist. t The author's friend well explored the muscology around, and gave him specimens obtained not far from Llanberris, most of which were rare or curious. $\$$ The ferns are

* Cerastium alpinum, Ranunculus gramineus, and Alchemilla alpina.

+ Cerastium latifolium; the rose root or Rhodiola rosen; the alpine, starry, and purple Saxifrages, Saxifraga nivalis, stellaris, and oppositifolia; the moss campion, Silene acaulis; the dwarf and reticulate willows, Salix herbacea and reticulata; Thalictrum alpinum ; the mountain Spiderwort, Anthericum serotinum; and the alpine Sawwort, Saussurea. Other plants to be found are Carex rigida and atrata; Arabis petræa; Fostuca vivipara, and Cochlearia Grænlandica.

$\ddagger$ Fontinalis, Batrachospermum, Lemania, Scytonema, and Strigonema.

$\S$ Andræa alpina, nivalis, and Rothii, Edipodium Griffithianum, Diphyscium, Tetraphis Browniana, Splachnum ampullaceum and mnioides, Bartramia ithyphylla, Polytrichum alpinum and hercynicum, Gymnostomum Lapponicum, Glyphomitrion Daviesii, Hookcria lucens. 
much sought after ; their Latin names are sufficiently well known to ladies to warrant their enumerationAsplenium viride, Aspidium lonchitis, Cyathoea regia, Lastrea fenisecii, Hymenoplyylla, and most of the Lycopodia.

From Llanberris village Twll $d u$ and Llyn Idwal may be attained by ascending one of the Cwms, passing Glyder fawr and Llyn y Cwm, by foot, or by the leelp of a pony and guide. The botanist will in this journey meet with most of the Snowdon plants, as well as others, * mosses and ferns, some of the latter especially, as the guides affirm, not now found on Snowdon. $\dagger$ Llyn Idwal is a less distance, however, from the road leading from Capel Curig, past Llyn Ogwen, and through Nant Frangon, from which road indeed the lake is seen, or rather its deep and gloomy hollow in the mountain side. Here is one of the wildest regions in Wales. There is another small lake, Llyn Bochlyd, lying between Glyder fach and Tryfan, both of which present summits of the most rugged character, the latter with upright stones, looking in the distance strange and wild. It is on its side, at a considerable elevation, that the geologists have lately discovered shells of recent character, geologically speaking. Nant Frangon constitutes a beautiful walk or drive, and between it and the Conway valley lies a wild tract of country not often explored, having no road through it, and including Carnedd Llewelyn, C. Dafydd, and Ysgolion duon, all rising. above lake Ogwen, with many other mountains northward, as seen in the grand bird's-eye view from

* Trollius, Draba incana, Hieracium alpinum, Poa alpina, Juncus triglumis, and Apargia taruxaci.

† Bryum Zierii, julacoum, and turbinatum, Woissia acuta, Woodsia ilvensis, and Asplenium septentrionale. 
Beaumaris and Anglesea, and those to the east rising above the valley of the Conway; the district of course presenting valleys, lakes, streams, turbaries, and rocks; most tempting, one would think, to the unhackneyed explorer.*

We had to retrace part of our road to get to Capel Curig, through the pass of Llanberris, where many good plants may be gathered close to the road-the Kidney Sorrel (Oxyria), the Cochlearia, the Butterwort (Pinguicula vulgaris), Hymenophyllum and Glyphomitrion. I lost a good Vasculum in the pass, which I put down at the foot of a loose rock, thinking I could recognise the spot again, after reconnoitering with the telescope, and viewing Dolbadern Castle or Tower; but there are so many rocks around, and they are so confusing, that I could not find my box of plants again, nor two or three other articles cast down with it. At Capel Curig there are also some rare plants to be had. $\dagger$ The place has not the soft beauty of Bethgelert, but wilder features. Its view of Snowdon is justly celebrated.

The Penrhyn slate quarries are situated on the road from Nant Frangon to Bangor; we went over them, but it is not in us to describe them. There are curious dendritic infiltrations in the slate, but we heard of no fossils. The slates got seem in architectural effect to be surpassed by some other varieties, if it be not age solely that produces the change of colour. Those covering Lichfield Cathedral, for instance, have a delicate silvery and greenish-grey tint, very striking; none such appear in the present market.

* Ajuga reptans is found on Carnedd Llewelyn, and the Hieracium paludosum in Nant Frangon. The rare Irish Trichomanes has undoubtedly been found at a waterfall in this district.

+ Trollius Europæus, Pterogonium gracile, Tetraphis pellucida, and Eucalypta ciliata. 
From Capel Curig we may enter upon another of the mountain valleys, that of Conway', either by the Shrewsbury and Holyliead road and Bettws y Coed, or by a short cut across the mountains by the lake Geirionedd. This lake is in a wild valley, no house or tree near. A slate-cross at one end marks the site of the residence of the bard Taliessin; close by, on the grassy mound, I found plenty of the pretty orchid, Habenaria albida. I could find few traces of animal life in the lake, except some small Lymnæi, yet it abounds in trout, which a fisherman was successful in capturing by means of a weighted board, called a latch or otter, armed with lines and artificial flies, which he swam along the lake; but the fellow either could not, or would not, speak any English to give an account of his proceedings. The bogs abounded in Sweet Gale or Bog Myrtle, Cotton-grass, Sallows, and Hemlock-dropwort. In my descent to Llanrwst the Beech and Oak Ferns, Polypodium phegopteris and dryopteris, were abundant in the woods. I cane to a fine cascade as I got near to the village, and, on reaching the road, discovered Thlaspi alpestre, or the Alpine Shepherd's Purse, and a Stone-crop, Sedum rupestre, as well as a singularly cut-leaved variety of ivy, on the walls. The cottages were fiequently covered with vines. I visited the principal coraclemaiker living here. These little skiffs are fashioned with a framework of ash, and covered with tarred cloth, sometimes double. Some will hold three or four persons. They are used by fishermen on the Conway, but are dangerous unless understood. They are impelled by a spade-like paddle, exactly like one which we knew to be dug up in a bog in Staffordshire. In working the paddle it makes a figure of eight. A good coracle costs three pounds.

In the river above Llanrwst, I searched for the 
Alasmodon, the real British pearl-mussel, and got a supply, but no pearls were forthcoming. One young woman, however, had a very fine one, found, she said, by her brother, but as she would not part with it at any price, I opined that brother, in the language she spoke, inchuded another tender liaison; however, she had two other specimens, which she let me have. I went to the church, which was very interesting in its interior, the cofrin of Llewelyn ap Jorweth being shown, very handsome, but without lid or inscription. The young woman who showed me the church emphatically impressed upon me that he was the husband of the natural daughter of King Johm. She seemed to think that to be the natural daughter meant something transcendentally correct and dignified, and as it was not for me to illuminate her on that point, I left her to her natural simplicity. There was also the recumbent effigy of a warrior, with an inscription, 'Howell Coetmer, grandson of Darid, brother of Llewelyn the Great.' There were likewise sereral brasses in the costume of about Elizabeth's reign, belonging to the Grynnes, and another in a later costume quite à la Lely, and, from the style, I, in my ignorance, at first set it down to represent that fast young lady Nell Gwynne, who, however, had no claim to belong to this ancient house.

I took the little steamer at Trefriw, at the height of the tide, for Conway; passed many pretty topus on the river, one pleasing spot being Rhiw, the site of the Roman Conovium. It was dusk as we approached Conway; the darkly-wooded hill and castle to the left, the bridge in front, the rounded rocks of Diganwy and the Great Ormeshead to the right, composed one of those scenes which one occasionally sees, not soon to forget. 
GOWER.

\section{CHAPTER V.}

THE PENINSULA.

Ox the northern shore of the Bristol Channel, and forming the eastern side of Carmarthen Bay, of which the coast about Tenby forms the western, exactly opposite Mlfracombe on the Devonshire shore, lies the Peninsula of Gower, in many respects a peculiar district; at any rate as retired and unfrequented a place as can well be, and on that account offering, to one who really seeks seclusion from the busy world, more inducements than the two other well-frequented but beautiful watering-places just alluded to.

It was an early morning in May, but of a forward year, and the dew or gentle rain dropped gratefully on the warm earth, as the train conveying us on our way to South Wales shot under the hill on which stood the ancient walls of Shrewsbury Castle; the wooded precipice rich, too, with springtide verdure and the blossoms of the Viburnum and other trees. Below was the Severn; to the left some fine churches and tpeir towers and spires, whilst above our heads numerous sivallows were dashing about, to me the first of the season-sweet tokens of winter past, and heralds of summer to come, with its sunny and pleasant hours.

As one journeyed southwards, one could not but be interested in the country. It was some years since I had read with pleasure the description of the 
geologist who had named the rocks and strata which I saw on the sides of the railway-cuttings, Silurian. Less congenial pursuits had always prevented a yisit to the district, and now time allowed only a glimpse of objects familiar from description. These remarkable beds of gravel, of what formation are they? These hills to the right are of the Cambrian system; there to the left rises the Caradoc of igneous formation, being continuous with the Wrekin, which lies further to the left in the north-east direction; further on still, on the same side, as we travel due south, are the Clee Hills. Then we caught sight of the Longmynd of Lower Silurian to the right, and further away was the Shelve district of the Cambrian. We then passed Church Stretton and Stoke Say, the former pretty in situation, and the latter possessing a castle, or rather ruined hall, and situated on a fine stream. All was pleasant; the swelling hills rejoicing in the gentle rain and sunny gleams; the gardens bright with their bursting blossoms and the glowing broom. Next we came to Ludlow, with its fine church tower; and here were more cuttings through a gravel apparently similar to that nearer Shrewsbury. The Herefordshire meadows were full of white-faced cattle, and at some places there were extensive orchards, rows of poplars covered with mistletoe, and a few hop-grounds, but these late plants were scarcely visible as yet. There were extensive cuttings and quarries in the Old Red Sandstone at Pontrilas and Hereford, looking very tempting to a geological neophyte like myself. About Abergavenny is a fine sweep of country, and near the town are the Sugar Loaf Mountains and Skerrid Mawr, and soon to the right we saw the high hills of limestone and grit, which form the northern barrier and base of the South Wales coal-field; the 
country now less pleasing-indeed barren enough towards the coast, with many marshes and sand-hills, $\mu /$ or bofrows, as they are called.

At Cardiff the country again smiles; we see the church and castle to the right, and pass through a picturesque and wooded district to Bridgend. Alas! again whirled through extensive quarries without the chance of stopping to examine them. Those ruins, too, must they be passed without antiquarian examination? To leare such ancient spots unexplored always gives one a pang; to some they have the same charm that glory and gold have to others. Here is Margam, where both Roman and saint have trod; we must pass on with the poor determination to refer to Camden when at home. On the other side, near Britton Ferry, are some more ancient objects, druidical stones, and the Giant's Grave. Here is Neath, also with a castle; and, looking down to the left, amidst a Tophet of smoke and flame we catch sight of the extensive, black, and shattered ruins of Neath Abbey. Then, as we approach Landore, we see on an eminence to the right a fine quadrangular antiquity, called, I believe, Morris Castle, and finally leave the rails at Swansea. From Swansea a drive of ten miles brings one into the centre of Gower, or rather (keeping the south road as we did) to a point of the coast, Nicholastone, about midway between its two extremities, for the peninsula is of a lengthened quadrangular form, its widest diameter from east to west, or from the Mumbles to the Wormshead, being about twenty miles in a straight line. Our road was at first pretty, then tamer, and afterwards led through the pleasant valley of Park Mills, affording a peep of the sea to the left at one of the romantic coves so common here; the 
shore presenting some bold rocks or Tors, whilst above, on the summit of a high precipice, half rock, half sand, is seen the rude ruin of Penard. We were put down at the south-east extremity of CefnBryn, a hilly ridge composed of coarse conglomerate of the Old Red, running obliquely lience northwest to the extremity of the Peninsula. We had a cottage on its skirt, looking southward, and a sloping tract led to the shore of Oxwich Bay about half a mile off. Immediately in front was a little intalie or: croft, with a hedge of flowery gorse on each side, the haunt of numerous linnets, whin-chats, and other pleasing songsters; at the bottom was a springy piece of ground with some apple-trees in blossom, and several clumps of Osmunda regalis. Close to the house was a bushy border of Euonymus, Hydrangea, Laurestinus, Fuchsia, Jerusalem Sage (Phlomis), and Bay, all very luxuriant. And now it is novel and pleasant, after leaving a few hours since the busy manufactories of central England, and the hurry of the iron road, to gaze unnoticed on that sweet bay, so calm, yet frilled by a surgy margin. The change, the novelty, adds inightily to its beauty.

Our first walk was down to the shore, following a woody glen or ravine, luxuriant indeed with ferns, which were, however, principally of two kinds, Polystichum angulare, and the common Scolopendrium. We had left the centre of England with the spring but half come in; here the trees were in full foliage, most umbrageous. We noticed Hypericum dubium, the Columbine, and Euphorbia amygdaloides, or the Wood Spurge, the two latter in flower. To the woody hollow succeeded a barrow of sandy hillocks, where the fragrant Spiny Rose, as well as the red Geranium were just expanding. Numerous individuals of the 
seven-spotted Coccineila were crawling on the herbage, and in the flowers we found the Chrysomela graminis, a brilliant little beetle.

In one thing I was disappointed here-I was too far off the shore; for, after a killing ramble over the rocks or along the rough margin of the sea, a long and steep climb home is very fatiguing; and I came to the conclusion that a naturalist-that is, if he is like the writer, getting on in life's course-should, if marine objects still fix his attention, seat himself close to the shore. I also found that at low water the rocks were not washed by the waves, a sandy tract intervening, and in consequence they were less productive. These sands were, however, strewed with Spatangus, shells of Lutraria, Mactra solida, Solen ensis and siliqua, Solecurtis, and other common débris. In the little pools at the foot of the Great Tor were numerous specimens of the Sagartia nivea or Snowy Anemone of Mr. Gosse, though the disks were more orange-coloured than he describes; the tentacles, however, were snowy enough, and their stars looked very pretty; they were hard to chisel from the limestone, in the fissures of which they were attached. There were also fine specimens of Bunodes crassicornis. I dug up a large worm, Nephthys margaritacea, out of the sand, also a small pearly Syllis and a yellowish Phyllodice. The lowest rocks were covered with masses of the arenaceous tubes made by Sabellaria alveolata, and their crevices were filled by the small tubes formed by another annelide, Spio seticornis. In the sandy tubes attached to Laminaria saccharina were the small crustaceans, Caprellæ, described by Mr. Gosse. We also got specimens of Cellularia avicularis, Coryne pusilla, and Laomedec geniculata, attached to an Amorou- 
cium, and the little group gave me employment in watching their beauties through the microscope the whole of a wet morning. There was also a bottle-shaped Grantia, and I got specimens of the graceful Sertularia cupressina alive. Aurelia aurita was floating in the pools. I longed to climb the Tor for some plants which I fancied I could distinguish, but was forced to leave them to the study of the crows, gulls, and hawlks, and content myself with the telescopic sight of them. Lower down was the Samphire, and a botanically different, but, both in look and taste, a samphire-like plant, Limbarda crithmoides.

Below our cottage were three of the rocky eminences, or Tors, with little bays or coves between them. When returning by the easterly bay, one has to climb a sandy hill, where, half buried, are the walls of the old church of Penmaen, almost forgotten till of late, and forsaken for ages for one on a more convenient site above. Or one may get home by turning the westerly Tor, and thence through a beautiful wood, which extends quite down to the sea. This wood was, as we afterwards found, a charming retreat, and at this season alive with the feathered tribe. We made out the note of almost every common bird; the tits, the warblers, the thrush, the blackbird, the jay, all frantic as it were in song. As we lay down at night the cuckoo's note might be heard from the margin of the grove, and so on waking at break of day. The white throat, the chiff-chaff, the garden warbler, and the willow wren, were recognisable. $\mathrm{On}$ and about this westerly cliff were a variety of plants-the Horned Poppy, just opening (May 10), the Gromwell, the Chlora, Euphorbia paralia, Turritis, the Rock Rose, the Buckthorn, and the Beam Tree; and in the wood the Butcher's Broom and the large 
Juniper. Numerous butterflies flitted about-Lasiommata Megara, Conoryapha Pamphilus, the pretty Polyommatus Aigon, together with the peacock and orange-tip. Cyclostoma elegans was a common shell, but I looked in vain for the pretty Helix pisana, found out the opposite side of Carmarthen Bay. A blindworm (Anguis fragilis) lay in the path, recently alive. The rocks here are highly inclined, almost perpendicular, in fact, shelving towards the sea, and having. many fissures or cavernous partings, which add to their picturesque effect.

On my next ramble, I turned by the most easterly Tor into Three Cliffs Bay, where a small river enters the sea. We may follow up the river, disturbing the heron in its watery haunt, and driving the wheatear flittingly along the stomes and shingle, till we come to Park Mills, from whence it may be followed further through an extensive wooded valley. Above, to the right, is Penard Castle, a shattered, bare, and melancholy looking ruin, with remains of a chapel at a little distance. Higher up the valley, after crossing the road, we have another ruined chapel; higher still to the right is the church and village of Ilston; or, if we keep the west woodlands through some ancient oak woods, we shall get on the back of Cefn-Bryn. Draba aizoides, Hutchinsia petroea, and Salix Smitheana grow on or near Penard Castle. I found, too, in my walk, the Madder, Enanthe crocata, the Tree Mallow, and the Fœtid Hellebore, the latter in exactly the same spot as mentioned by Turton more than half a century ago. We have noticed the same persistence in a single root of Helleborus viridis growing by Dove-side; and it may be made out that on one bushy spot a few plants of Lathyrus angustifolius have flourished for at least a century, and only on 
that spot for many miles. Is it here an interloper, or the last survivor of its race? We fancy the latter. If we keep along the shore eastwards, we must cross the river, and after passing through a natural arch in the rock, we come into a wider bay; but the next point, Shire Coombe, appears to be impassable, even at low water. We could but search the rocks at the foot of the Coombe, and then ascend over the curious sand-hills to the ruins. Some birds had been better shore-hunters than ourselves, for at one spot we noticed quantities of the remains of the Lepas anatifer, no doubt brought up from the shore, the soitt parts usefully disposed of; some drifted log covered with them had probably come in with the gales of the preceding winter. On the waste were the common plants of such localities; also Brassica cheiranthus, Cladonia furcata, Hypnum triquetrum, \&c.

From Shire Coombe eastwards to Pwlldû Point, great headlands and rocks rise in one straight line, almost perpendicularly, out of the sea. The rocks are hollowed with caverns and immense fissures, adding to the wildness of the coast. The most remarkable caves are Mitchen and Bacon Holes. From these Mr. S. Bate, Dr. Falconer, and other diggers, have been successful in extracting bones and teeth of the ox, bear, liyæna, wolf, mammoth, and rhinoceros ; and in the black mud above the ossiferous stalagmite, recent shells, as the dog-winkle, limpet, and mussel, together with fragments of pottery, were found. The last-named cavern opens on the face of the middle of three headlands, of which Pwlldû is the most eastern and the highest, and has an encampment at its top. One or two other fissures near surpass Bacon Hole in pictorial effect, and are more festooned with vegetation. The sea Asplenium abounds. East of Pwlldû 
the coast line is more sinuous, with several coves and bays; and on this side the valley of Bishopstone debouches, extending inland several miles, and presenting very beautiful scenery. More easterly still, along. the coast, comes Brandy Cove, smacking of ancient smuggling transactions; and still further on are the beautiful Caswell and Langland Bays, with Whiteshell and Snaple Points between them. These bays are often frequented by visitors from Swansea and other places. At the extremity of Gower in this direction is the Mumbles, which we visited afterwards from Swansea.

The tides have a great rise and fall along this coast from the natural configuration of the Channel. Though the scenery of Gower rarely approaches the sublime, and not always the grand, yet it is remarkable for presenting ever-new and beautifully-varied walks. Cefn-Bryn is of no great height, yet a walk along its ridge is very fine. Southward one sees the south line of the Gower coast, part of which I have described, and beyond the Channel the distant shore of Devon. Through the telescope, indeed, one may make out the hills and rocks with other objects about Ilfracombe. At the present time full sixty vessels are sailing at no great distance opposite to where I stand. In the west is Lundy Island, as far off as thirty-five miles; yet, as twilight approaches, its revolving light will become visible. The extreme west of the Peninsula is somewhat cut off from vision by the higher western portion of the ridge, and by Harding and Rhossili Downs. On these latter are cairns, and cytticu or the sunk foundations of the round or oval British huts; also three or four camps of round or rectangular outline. Northward is a fine view of that side of Gower, with some remains of ancient forest 
following the valleys down to the sea, a proportion of common or moor, and, more north still, the Burry estuary, now all sea, as it is high water, but at low water more or less dry sands; with the smaller rivers, under the name of pils, running through them into the larger Channel. On the opposite shore is the railway, in its course from Swansea to Haverfordwest, \&c.; further on, the blue mountains of Carmarthenshire. We also see the rising smoke and vapour from many works along this coast, as near Castell Llwchwr and Swansea, further to the right. But, looking nearer on Gower alone, those factories and furnaces miglit be far away, for they seem to have no bad influence on the appearance of the surface or of vegetation, and I was too well versed in the effects of such works not to notice them if they had been present. Vegetation was rank, even close to the sea, if it was sheltered from the force of the westerly wind. A sort of eudiometry, by means of observations on trees and plants, may be carried out in mining and manufacturing districts, and thus a judgment made of their healthiness or unhealthiness. From Cefn-Bryn, too, the eye followed the line of the northern shore of Gower itself; here a Tor, village, or ancient castle; there a woody knoll, or valley, or the track of a little river falling into the Burry. This coast we saw no nearer, but we have no doubt it is worth a visit; for instance, Landimore and Weobly Castles, witl several village churches, particularly the abbey church of Llangenydd, and, to boot, the neighbouring Celtic remains. After passing, on Cefn-Bryn, the source of one of the above rivulets, considered to be a holy well, we came up to a huge grey boulder on the common, quadrangular-looking as we approached, but triangular from other points of view ; this was Arthur's Stone. It lies in a basin-like 
hollow, reposing on six or seven other pillars or stones. We may well suppose that it was originally found here on the common, where it now stands, by the aborigines, who dug away gradually the soil and stones from under it, and substituted, as they proceeded, boulders or pillars to support it, one by one, as they removed its original bedding. It is of from twenty to thirty tons in weight, and is composed of the same conglomerate or pudding-stone as the mountain itself. From its weather-beaten sides we picked Parmelia saxatilis and omphalodes, Ramalina scopulorum and Lyngbya muralis. Close at hand was a barrow, which had evidently been explored by a quadrangular digging. In many places the pretty Cicindela compestris was skipping about. Bryum nutans and Weissia curvirostra grew around, and in the springy places a Jungermannia ( $J$. cordifolia?). The range of hills was the feeding ground of numerous crows, whose nests were built in the cliffs overhanging the sea.

These hills are composed of the conglomerate constituting the upper bed of the Devonian. Its components are bound together by a cement wonderfully strong. Quartz pebbles preponderate, but there are fragments in it of other kinds, as grey and red pieces of coarse texture. We only saw one fossil in the stone, a long vegetable stem, but with no markings. The ridge would appear to run in an anticlinal line of elevation, the overlying limestone dipping on each side from it, sometimes highly inclined. At the Mumbles, somewhat north of the line, the dip is rather northwards, or towards the South Wales coal-fields, whilst the steep rocks to the south have the reverse inclination, excepting along the Paviland or western range of coast, where the limestone again 
rises with its escarpment towards the sea, forming a small trough with the limestone which lies on the south side of Cefn-Bryn.

That heterogeneous race, the Normans, together with some Flemings, who were driven from their own country by an inundation, supplanted the British in Gower, Gwyr, or Guhir ; consequently, the inhabitants are not Welsh, and that language is never heard. They speak good English, and without provincialisms, having no surrounding dialects to corrupt the pronunciation learnt at school. With respect to their appearance, they have brown or even black hair, and corresponding eyes, the former rarely light or red, the latter as seldom blue. They are taller than the Welsh, and possess more regular features, and not unfrequently the nose is aquiline. The women are, however, less handsome than the men, from their exposure to the weather and hard work. The females are sometimes seen with high conical hats and red whittles or shawls, the yarn for which they sometimes spin from their own wool, and frequently dye themselves. In the cottages one sees upon frames in the ceiling the bacon which is their only animal food; the floors are unpaved. They make their milk and meal into puddings and porridge, with one or two curious names not worth recording, however, as few will desire to learn their cookery. I met with some curious specimens of ancient pottery in several of their houses; for instance, Nantgarrow and Swansea ware, but especially fine ewers or jugs, some very old, and formed of Delft covered with opaque glaze, and coloured and lettered in various ways by manganese, but these, they told me, were from Bideford, or some place on the opposite coast. There are some unusual surnames scarcely Welsh, some with a 
foreign sound; and it is said that they have a peculiar vocabulary for other objects; but some of these words seem common enough elsewhere, though a few may be of Flemish derivation. It is also said that the Gowerians are naturally fond of gaming, and that their games are intrinsically foreign. We noticed, on the other hand, regular Welsh pig-styes, circular and with conical thatch, and frithings or fencing made of wicker-work. At a school hard by we found that no child could understand Welsh, and only one or two had any tendency to light hair or eyes. At the unionhouse the inmates, though their former mode of life at home must have been hardy and stinted, were better treated in every respect than the less hardy paupers of the manufacturing centres of England.

The best locality for the naturalist available was Oxwich Point and further on westwards. We readily got down to the bay of the same name through the aforesaid wood, waded through the pil, and, as the tide was out, cut short the walk by going across the sands of the bay, and so reached the Point, situated at the end of a long wooded promontory. Another road is to pass Oxwich Church, venerable and secluded, where we may examine the recumbent effigy of a Delamere which it contains, and may at the same time collect a bunch of the fine blue flowers of the Vinca major which grows about; or we may prefer to cross over the promontory to its western side, ascending the hill past the castle, which, as well as Penrice Castle, was anciently owned by the Mansels, whom Talbot of Penrice now represents, owning a good portion of this district, though the Duke of Beaufort is Baron of Gower; or we may, lastly, for the sake of what we can find under the loose stones, follow the margin of the sea. On returning, in any 
case, one may pass through the woods. The Primrose is over, but there is the red Orchis, the Sweet Woodruff, the Veronica montana, and at the Point the Vernal Squill. On the shore there are many overhanging ridges of limestone, such as the marine zoologist loves to explore; and on such a shore as this, shelving down into the sea, something may be done with a small dredge, which I reckon my own invention, to be thrown out twenty yards or more and then drawn to land. Here is a strange collection of tho common Asterias; they look handsome enough, but at present I do not want them. Here, however, is Ophiura texturata and neglecta and Ophiocoma bellis. Under a large stone is a family of Eolis Embletoni or rufibranchialis ; and here are specimens of Doris pilosa, some white, others nearly black, also the pretty Patella ccerulea. Is this the spawn of the Eolis or of the Doris? found under stones, a mass of twisted and adherent gelatinous laminæ, some white, some pink, presenting under the microscope clear round globules in abundance, each one containing from eight to ten ciliated fry, and each of them covered with a spiral shell and rotating. Of crustacea I found Portumnus marmoreus, Pilumnus hirtellus, and Porcellana platycheles. Here, too, was a large common crab, which I endeavoured to cram into the pocket of my overcoat, but unfortunately he caught hold of its fold as I was making the attempt, nor could I disengage him without brute force, so I was necessitated to let him hang there, which he did for an hour or more, half in, and half out. Balanus porcatus and Chiton ruber occurred on the rocks. In crevices of the limestone was the Sagartia bellis; Lobularia and Polyclinum, Botryllus Schlosseri, and one or two other similar species also occurred under stones, some with yellow 
stars, some white and red, whilst in others the individuals were disposed in double meandering lines.

A friend last year found on this coast the oceanic Portuguese Man-of-war (Physalia) and the Velella, both abundant, having been driven on shore by the westerly winds. Janthina communis, with its living animal, has often been seen. I was less fortunate, meeting with none of these, nor with the Caryophyllia or Balanophyllia found at Tenby and Ilfracombe, the latter also at Lundy Island. I set down their absence to my own bad search, or it may be to my stay of but a fortnight. The tides are a momentous consideration in such cases, as little is to be done at the seaside at any but the low tides at full and new moon; at such times, too, there is probably but one available tide in the twenty-four hours, let alone the chance of weather.

In the bay I picked up some specimens of Medusa; some had four purple semicircles, some six, and other specimens, smaller and more convex, had them in fewer numbers. In a walk here, one as usual incommodes the flocks of grey and herring gulls, guillemots, and razor-bills, who, particularly if it has blown a little hard, meet with a plentiful repast on such shores. The sands were covered with the pits and castings of the Arenicola, two marks about ten inches apart to each worm. Of sea-weeds, $H i$ manthatia lorea, Chordaria flagellata, Ceramium rubrum and diaphanum, Polysiphonia elongata, Rhodomela scorpioides and Chylocladia articulata, were picked up. The Solen or Spout-fish several times surprised us with its jets of water, and I dug out or picked up Mactra solida and stultorum, Venus striatula and fasciata, Nucula nitida, Pholas parva, Lutraria, Donax trunculus, Leuconopsis undata, Lucina, and Diplodonta 
rotundata. Montacuta bidentata and ferruginosa and Cacum glabrum are also to be found. I got, too, Ligia oceanica, Portumnus depurator, and the female of Corystes Cassivelanus. Portumnus longipes was found in the bay by Mr. S. Bate. Nearer home, embosomed in the wood, was the house of a keeper, with one of those rustic museums which one sometimes meets with in the form of a goodly array of so-called vermin nailed to a board or door-kites, hawks, owls, weasels, and, I am sorry to add, poor cats, who very likely had been following that natural propensity of both quadruped and biped to break the game-laws. From the extremity of Oxwich Point is an interesting view eastwards of the coast already described, with the Mumbles (of the Lighthouse itself I am not quite sure) at the extremity. Bacon Hole and other caverns, can be recognised on the face of the opposite cliffs.

I had two interesting rambles to the west. I arose at early dawn, and passed Nicholastone Church; there was no walk within the enclosure of the churchyard, but its turf was rich with Cowslips, the Purple Orchis, and clumps of the White Narcissus, no doubt originally planted, but now naturalised. I then came to some old towers, the portals to Penrice Park, through which my way passed. There were numerous groups of Daffodils in the turf, but now faded. A little later in the year I should meet with Ophrys apifera and Listera nidus avis on the limestone here. I climbed to the old castle, the walls covered, as usual here, with the Red Valerian and the large Snap-dragon. The lake was full of the pretty Bog-bean (Menyanthes) in flower, but looked as if the salt water got access to it, and I believe some kinds of sea-fish live in it. Some of the trees here are fine, the Stone-pine, the Holly, and 
the Ilex. I next climbed the hill, and passed through the churchyard and village of Penrice. There is a mound near, and I noticed a Gothic moulding lying by the roadside amidst a heap of other stones. I pushed on for two or three miles, till I thought I could hear the murmur of the sea to my left, when I turned in that direction, as I hoped to come upon Slade Valley, of which I had heard, or Port Eynon. I shortly came to the village of Horton, and a little further on saw Port Eynon, with its church, pretty well cut off from the rest of the world. I got some breakfast, and spent the morning on the shore. I wondered-but be it remembered that wonder is but uninformed curiosity -whether the port was named from Exion ap Cadwin, the son-in-law of Jestin ap Gwyrgant, a vassal of Rhys ap Twrdwr. Jestin rebelled against his prince, and called in the Norman Fitzhaman to his aid. Camden says that, long before this period, Kynedhan, a British prince, had driven out of the peninsula the sons of Keian, a Scot. There is still in Gower a place bearing the name of this last Briton. Camden also gives the names of twelve Norman chiefs who flourished in this part, and says that the Stradlings are descended from Willian Easterling, one of them, and observes that they remained in his time with Turbevilles and Flemings. In early mediæval times we read of the often questionable doings, in Gower and adjacent district, of some of these Norman chiefs-of the Earl of Warwick, of William de Braes, and of the De Spencers. But, to return to Port Eynon: there was a curions hollow to the right, with strong stonework upwards, called Culver Hole; what may have been its use. seems difficult to say. A headland shut ont the view in this direction, but on the opposite side is seen 
Oxwich Point and some little valleys. There is a grassy knoll some way out, almost an islet at low water ; Crambe, Euphorbia, Statice, and the Vernal Squill grew on it or about it. Elecampane (Inula Helenium), and several other plants sometimes found in such places, occurred in the little pastures about the village. I met with an old fisherman, who, after deploring that his trade was falling off, oysters becoming scarce, and so on, entered into a learned exposition of the tides at my request, quoting not only the tide-table, but finally Sir Isaac Newton himself, to convince me, and in fact teaching me more than I could ever collect from either books or learned lecturers. He bagged a good quantity of crabs from holes in the rocks, and procured me specimens of the harbour-crab in the act of casting their shells, showing a splitting of the base of the claws as described by Reaumur, but denied by other observers. The best fish here appears to be the bass, being both large and excellent eating. and commonly caught with a harbour-crab for a bait; a piece of one constituted the contented old fellow's dinner. A few days later I went further in this direction to Rhossili and Wormshead, at the western extremity of Gower. Much of the road was bare and uninteresting, and I should say remarkable for nothing except the flocks of geese. Michaelmas must be the feasting time here. We ourselves were ten miles from a butcher's shop, and I could not help looking with wicked eyes on the flocks of goslings; for, except one or two rabbits, our dinners had been an alternation of ham and eggs with eggs and ham. Three miles or so from the end of my journey I turned to the left over some fields past Paviland, near which farm are some celebrated caves in the rocks overhanging the sea. These cares, 
called Hound's Hole, Goat Hole, Deborah's Cure, \&c., have been described long since, with their osseous remains, by Dr. Buckland, in the 'Reliquiæ Diluvianæ,' a description not only full, but interesting. A female skeleton was found in close contact with an elephant's skull, as figured in the plate; ornaments for the person had been formed out of the tusk of the same animal-but was it recent or fossil when so worked? With my opportunity and time I could not explore; indeed the caves can only be safely visited by boat, except for a short time at low tides. I had to content myself with rambling along the cliffs, noticing the camps on the summits of two or three of them, whither evidently the poor aborigines had been driven either by Roman, Saxon, or Norman, and where they must have been slaughtered or have thrown themselves into the sea beneath. From Port Eynon to this extremity of Gower the rocks are very grand, approaching the sublime. The sun was getting low beyond the Wormshead, and headland beyond headland appeared in obscuro, the effect being very pictorial. I descended into several of the coves, but at last was quite satisfied with this kind of scenery, and got to Rhossili, only to find there was no hostelry. I returned to Pilton, which I had passed before, and was taken in for the night at a farm-house, kept by one Beynon, a Gower name.

Later an old fisherman and shore-hunter came in, and I heard much of the country, and of disasters and wrecks at sea to boats, steamers, Spanish galleons, and so on, causing my fancy afterwards during sleep to be mixed up with several sad and melancholy scenes, real incidents that had happened, or entirely baseless imaginings. In the morning I walked again to Rhossili, a wild and out-of-the-way village. The 
roof of the church tower was saddle-shaped, its south door of fine Anglo-Norman build, with zigzag and cross-work mouldings. In the churchyard were memorials of some who had met with their deaths from the treachery of the sea. At a farm-house near was a remarkable ash-tree, so bent by the rvesterly winds that it entirely roofed in a good-sized farmyard, just above the heads of the cattle and hinds, growing in fact perfectly horizontal. I went with a fisherman over the rocks to the Worm, the latter only accessible at half-tide. The treading was awkward, but the Worm itself was covered with good turf, with sheep grazing on it, and of a perfectly level line along its top. After coming to its extremity some difficult and rather dangerous rocks are to be passed to get to the head; at' one point an arch has to be passed, through which the water dashes. Then, if bold enough, the visitor may ascend the veritable Wormshead itself, rising upwards into a rounded but bold elevation, against whose side to the right the waves were dashing wildly, and rising up in the form of spray and mist into the air. This could be well seen from under an arch which looked out on this side; it appeared that the water dashed into a hollow from which there was no egress of consequence, but having only a small opening above, where sometimes the air is driven through with an audible noise. To the right was a beautiful bay, the white waves breaking on the curved shore, and on its margin was one house and a few fields - the parson's, who I thought should be a naturalist, living in such a locality. Above were high downs and barrows, and cairns and cyttiau, and on the other side the bay was Burry Holmes, lower and tamer than the Wormshead. Directly out at sea was the Tenby coast, the town 
itself, its streets, and Caldy Island visible, also St. Gowan's and Lundy Island; south were the Helwick Sands, with a lightship on the western end. Some of the trawlers, too, of whom my friend at Port Eynon complained, were at work here, at a little distance off. There was abundance of those interesting creatures, sea-birds, on the rock, guillemots especially, called lungy or Lundy birds, mers, or sometimes eligug (gwglawg, Welsh); razor-bills, poethwy (Welsh), also called grvalch y penwaig; and the puffin or pûl. The harry bird, mentioned by Camden in his account of this rock, appears to be the shear-water or Manxpuffin. The cormorant is mulfran in Welsh, the gull, gwylan. Anthea cereus abounded on the rocks, but all were of the brown variety; also the little molluse, Nassa reticulata. Some of the drifted timber, which I saw lying on this iron-bound coast was much bored by one or two species of Teredo or shipworm. I returned by the rocks which I left unvisited the night before, passing magnificent Tors, fine arches, cavernous recesses, isolated pillars, and every variety of rock scenery. An old woman was gathering laver for cakes to go to the Swansea market, and some children were bathing and dancing amongst the pillared rocks in some natural baths. Some rocks here gave one an idea how certain conglomerates, say those of the Devonian or Millstone Grit, might have been cemented into stone from the percolation of calcareous matter (in this case from the overlying limestone). Great accumulations of gravel were in the process of formation into firm rock. There were also heaps of boulders or rocks which were being ground down into large rounded pieces by the action of the waves. Along this coast, as on that of North Wales, I noticed remains of 
submerged forest. I ascended to my quarters by a pretty dell, called Mewsdale; there was a picturesque ivy-covered rock rising at the bottom. On the face of one high Tor, looking seawards, I raised my eye, and saw numerous shag's sitting on its ledges, watching either me or the fish, their glossy black breasts shining in the bright sun : one shout, and they took to flight, looking awkward enough with their out-stretched necks. The Draba aizoides grows on the highest of these rocks. Limbarda, Silene maritimum, Cochlearia, Helianthemum canum, and Erocium maritimum were common enough. On my walk home I passed the ruined Church of Knelston, the roof gone, the gables standing. In Colonel Wood's ground at Stout Hall is a large stone pillar to be seen from the road; it looks druidical, and there is a large cavern near. A large cork-tree is one of the curiosities of the place; and that gentleman possesses also, I believe, a large collection of bones from the caverns of Gower.

Our rambles in this pleasant country were now to be ended. In returning home, however, I stayed a day at Swansea, and thence went by the tramway, easily enough, to Oystermouth Castle, ivy-clad and seated upon a grassy knoll. We then clambered up the hill to the other side of the headland, got on the highest point, and had a fine view over Langland Bay, as far as Pwlldû, already mentioned. Swansea Bay, near as it is to poisonous emanations from smelting furnaces and such abominations, is pretty; and, by ascending these rocks, the good people of that town may soon have any degree of solitude they choose. The Mumbles are two rocks at the end of the promontory, the limestone dipping to the left, and on the furthest is the well-known Lighthouse. There is a 
cavern called Bob's Cave beneath. These places, ex. cept their names, are picturesque. We walked round the headland, but got caught in a thunder-storm. This headland has been fisstured across for the sake of a vein of hæmatite occurring in a gang of dog-tooth spar. The ressels used in the oyster fishing were now, as the season was just over, lying idle in the bay under shelter of the headland. Laurencia dasyphy?! $a$, Desmarestia ligulata, and Chylocladia $k a-$ liformis are sea-weeds occurring in this locality. Swansea Bay is also not devoid of interest for the botanist,* as also the interesting bays to the west, Langland and Caswall. $\dagger$ The name of Dillwyn has been intimately associated here, both with the cause of natural history and with the production of a true porcelain. Many rare mollusca have also been found off this coast, thanks to the dredgings of Mr. Jeffreys and Mr. S. Bate. $\neq$

At Swansea I paid a visit to the Castle, and another to the Museum. The former is built in on all sides, as much as its high walls can be, and its interior is applied to different purposes. There is a good deal to interest at the Museum; for instance, some large vegetable fossils from the South Wales coal-fields, effectively placed in the grounds. I saw few if any ichthyolites. From Spritsail Tor, near Burry Holmes,

* Matthiola sinuata, Silene Anglica, Convolvulus soldanclla, Trifolium scabrum, Sinapis muralis, Enothera, Datura, and Enanthe pimpinelloides are found here.

† Pulmonaria officinalis, Inula crithmoides, Euphorbia Portlandica, Statice spathulata, Neottia spiralis, Lathyrus sylvestris, may be met with.

$\ddagger$ Thracia rilliuscula and phaseolina, \&c. In the Museum at Swansea are other specimens found on the coast, but unfortunately not kept in good order. Fissurella, Murex erinaceus, Aplysia, Thracia distorta, Lucina crassa and virgata, Skenea planorbis and nitidissima, Philine catena and punctata, Adeorbis subcarinata, and Jeffreysa diaphana. 
were remains of the rhinoceros, hyæna, bear, and deer, especially teeth; and from the caverns of Paviland, bones of the tiger, hyæna, elephant, rhinoceros, beaver, elk, deer, fox, and wolf. On our way home we passed through Chepstow, picturesque enough with river, rocks, and old castle. Tintern! I never expected to be so near and yet leave it unvisited. At the station an old Welsh crone was selling penny bunches of the fragrant Lily of the Valley. We had a glance, tantalising from its brevity, at Gloucester Cathedral, with a distant view of the Cotteswold to our right, and of the Malvern hills to our left. Worcester Cathedral was passed still more unceremoniously than that of Gloucester, with a mere glimpse. But it made amends to be quickly getting nearer home, for that is a pleasure to some folks, even after so short an absence as a fortnight, and although we may have failed to do half what we intended at setting out. 


\section{CHAPTER VI.}

\section{THE LAND'S END AND ITS BAYS.}

THe Land's End is one of the most remote corners of England, and only accessible to ordinary mortals by a second-rate railway, or by less regular steamers; yet in several respects it is worth a visit, particularly from the naturalist. Taking in the Lizard it is both the most western and the most southern part of England, and hence has peculiarities of climate and of productions. Though it has nothing worthy of the name of mountains, yet its seaside rocks are magnificent and picturesque, and their geology, especially in a cosmical and mineralogical point of view, is interesting. The Cornish zoology and botany are both rich. The surface of the country also abounds with earth and stone remains of an aboriginal race, and its present people are likewise somewhat peculiar and worthy of notice. At the conclusion of our holiday we did not regret having bestowed it upon the Land's End, with its bays, inclusive of the Lizard.

The iron roads from the north and east of England converge at Exeter, and the railway south of the city soon begins to skirt the sea, passing Dawlish and Teignmouth, pleasant enough places. The sandstone cliffs are striking in aspect, being dark in colour, and variously worn down by the action of the sea. The high land of Dartmoor lies to the right, and presently a beautiful country of hill and dale and wood is seen 
to the left, the shore, however, with Torquay and its bay, being now at a distance and concealed from view. We would fain have stopped at the lastmentioned place, but who could say anything of that locality, or hope to find anything novel after Mr. Gosse's book? On to Plymouth : the country seemed beautiful park and garden. At that place we passed a night and, a day, the latter more pleasantly than the former. The harbour, the shipping, the breakwater, the fortifications, the limestone and slate quarries, Mount Edgecombe and the Saltash bridge, are all objects worth notice, but we cannot take upon ourselves to say more about them. The scenery continued rich through the east of Cornwall, with wooded valleys and with creeks running inwards. As one proceeds through the county, one may notice the higher grounds to be formed by four barren-looking hummocks of granite, and nothing surpasses a granite moor for sterility. The streams running from these hills are frequently white as milk, from the washing: of the china-clay, the product of the decomposed granite, or rather of its felspar. And now tin mines begin to appear, with their high engine-houses and taller chimneys, and accompanying mineral heaps, more numerous, however, as we get to the western part of the county. At Truro there was a stoppage of several hours, and we had a walk to some commons westwards, searching in vain, however, for the rare Erica ciliaris, which occurs between Truro and Falmouth, and also, it is said, at Lamorna in the Land's End district. Once again on the jolting rails, we got with many stoppages to Penzance, only about eight miles, as the crow flies, from the promontory of Land's End, the Bolerium or Antivestæum Prom. of the ancient geographers. The town itself is placed 
on the borders of the noted Mount's Bay, so called from the curious pyramidal islet of St. Michael, which forms its chief ornament. Penzance presents a fair number of attractions, considering its size, to the naturalist. Among them is the Museum of the Royal Geological Society of Cornwall, particularly rich in minerals, and possessing a general collection of fossils and other objects, including bones of the rhinoceros and hyæna from the Torquay caverns, and some other remarkable specimens-a jaw of the elephant, another of a whale, and a human skull found in some tin-workings in the neighbourhood; this last is of a very remarkable dolicocephalic or lengthened form. We noticed, too, a curious old copper pan with two handles, found at Marazion, and fine specimens of purple fluor in china-clay, slickensides, splendid copper ores, and specular and other forms of iron. The Natural History Museum in the dome of the Town Hall contains many preserved specimens of the rarer fish caught in the bay; amongst others, the oblong sun-fish, the thresher, the torpedo, the scabbard-fish, the boar-fish, the hammer-headed and the Beaumaris shark, and the monk-fish ; also interesting models of the Celtic antiquities of the Land's End and of the Scilly Islands, and some British vases, one or two of large size, dug up in the vicinity of Penzance. Unfortunatelyboth these Museums appear to be indifferently kept up, like most other similar institutions in the provinces, unassisted as they are by the public money, so monopolised at head-quarters. Penzance, too, is interesting as the birth-place of Davy; and the celebrated Borlase, author of the interesting old Cornish History, was the minister of Ludgran in the immediate neighbourhood, and was born at Pendeen House. It also boasts of many who in our days have 
cultivated different branches of natural history with success.

St. Michael's Mount itself, situated in the bay at a short distance from the land, and indeed joined to it at low water, near the village of Marazion, two uniles from Penzance, has a circumference at its base of only about a mile, whilst its height with the buildings upon it is said to be about 256 feet. It is steepest seawards, and its sides present opportunities of studying the junction of the different rock formations. A small payment made, the mineralogist or botanist may search about, and specimens interesting to both may be found.* Sheep and rabbits feed on its sides, and the Cornish clough breeds here. The Tamarisk las no difficulty in existing in this exposed place. There may be also picked the Yellow Fumitory, the Samolus or Brookweed, the Moth Mullein, and the Borage. The Mount is generally considered to be the Ictis of Diodorus Siculus, described as existing near the promontory of Bolerium, and the natives are mentioned as bringing tin to it over the connecting causeway for the merchants frequenting the island. Its monkish and civil history is also not without interest. Edward the Confessor founded its monastery, which was afterwards connected with that of Mont St. Michel on the French coast, and later with. that of Sion in Middlesex. The chapel, and other portions of the existing buildings, are ancient. The so-called chair of the great Archangel is shown, a giddy seat on the rock; the ruined lantern in the tower has the same name as well as supposed properties. Lady Catherine Gordon, wife of Perkin Warbeck, took refuge here, after landing at Whitesand Bay.

* Tungstate of iron and forms of topaz occur. 
Mount's Bay has a fine curve, and from Cuddon Point on the east to Mousehole on the west is about five miles across; but this is a kind of inner bay only, for out to the left, and dimly seen, stretches the promontory of the Lizard, forming the eastern side of the outer bay, the western being a continuance of the general line of coast. So much said, we will leave the geography.

What will the botanist find to interest him at this extreme west of Cornwall? In the immediate neighbourhood of Penzance the shore, the curious marshes, and the bushy lanes, all afford floral spoils. But first let us notice such peculiarities of the district as consist in deficiencies of forms, not uncommon elsewhere. There is a more complete absence of northern and mountain species than in the hilly districts of central England-no Saxifrages, none of the subAlpine Cruciferæ, the Campanulaceæ represented by only one species - the little Wahlenbergia, the Pyrolæ also absent; the Cowslip, the Sweet Violet, the INarshmarigold, the Cistus, and the common Broom, absent or rare. The Mistletoe is not indigenous, the Lemna minor appears to be the only species of the genus, and Hottonia and Nuphar, with many other aquatics, are either not common or absent altogether. On the other hand, a short walk on the sandy ground east of Penzance, with a détour through the marshes, which may be passed by treading along the raised banks, affords many plants not frequently seen elsewhere, and of which we subjoin the lists.* In the lanes and

* Coronopus didyma, Reseda fruticulosa, Exacum fliforme, Radiola millegrana, Linum angustifolium, Salix repens, Erodium moschatum, Henbane, Trifulium subterraneum, the Dodder (Cuscrita, epithymum), elothing the gorse and ling with its long red threads, the strong-smelling Bartzia, the true Chamomile, the shore Bindweed, and the Sea-spurge. 
bushy places about Gulval and Penzance occurred others, as Asplenium lanceolatum, the Tutsan, the Geranium stricutum, or what is called by lady botanists the pencilled Geranium, Scrophularia scorodonia, Sedum Anglicum and reflexum, the Clematis, probably naturalised like the above Geranium; Oxalis stricta, also an interloper', and the wild Madder. These struck the writer as noteworthy, but longer search, and in different seasons, would have furnished others.*

This part of England has, of course, climatal peculiarities: a winter mild, on account both of its southern latitude, and its being surrounded by the warmer sea, at least warmer in winter. The summer is sometimes so hot and bright, as to affect the body and try the eyes, but generally it is tempered by the now cooler sea, and by the formation of clouds over the waters to spread over the land. Spring produces early vegetables, as is the case more especially in the Scilly Isles; but summer is later than in Devon or Somerset, there being an amount of sun below the average, considering the latitude. Hence grapes do not ripen, though the mulberry does. There are said to be 114 fine days annually in Comwall, and the mean temperature at Penzance is $54^{\circ}$ Fahr. Of course there is much moisture in the air, the probable cause of the luxuriance of some plants-the Dodder, for instance. For invalids we fancy a better spot than Penzance might be found or built; Marazion, though a poor place, appears to be a preferable site, having less

Also the bog Bell-flower, the bog Pimpernel, Illecebrum verticellatum, Enanthe crocata, and Alisma ranunculoides.

* For instanee, Medicago maculata, Antirrhinum orontium, Linaria repens, Pinguicula Lusitanica, Seutellaria minor, Mentha pulegium, Littorella lacustris, Euphorbia Portlandiea, Neottia spiralis, Cladium mariscus, Briza minor and Cynodon dactylus. 
exposure to the east; Helston is more distant from the sea, but is more cleanly and neater. Black commons abound in the district, and the surfice is often disfigured by mining; yet there are many pretty and fertile valleys on the south coast of the Land's End district, wonderfully productive in spite of slovenly farming and manuring with sea-weed, pilchards, or sea-sind, and often fetching a high rent. Little hay is gathered, and we suppose green crops take its place. There are numerous orchards, but the trees are generally overgrown with lichens, yet there are one or two noted varieties of apples. There are few woods ; the Pinaster has been long grown, and forms some venerable groves, the plane and a Cornish species of elm also flourish. It is difficult to say what some of the enclosures are-fields, gardens, or orchards. About the houses may be noticed many rare semi-hardy exotics, which flourish freely-Escallonia rubra, large Aloes, Tree Veronicas, Camelias, Mesembryanthemums, Verbenas, Daphnes, Arbutus, Bays, Fuchsias, Giant Geraniums, Myrtles, the Cape Jasmine, the Tree Cistus, Budlæas, Syringa, Laurestinus, the Pomegranate, and sometimes Palms.

Our longest excursion from head-quarters was to the Lizard, Damnonium vel Ocrinum Prom., which the naturalist visits if it is solely for the sake of collecting four or five of its plants. Soon after leaving Helston the Cornish heath (Erica vagans) occurs in plenty for miles along the road (just coming out on July 6). Verbascum blattaria, and the Tamarisk also, ornament the roadside, the latter large and striking in appearance. On the Lizard, both species or varieties of Rupture-rort, or Ferniaria, are plentiful. Trifolium Bocconi is difficult to find, but $T$. Molinieri and strictum occur, also Salvia clandestina, 
Genista pilosa, the procumbent variety of $G$. tinctoria, Orobanche rubra, Allium schconoprasum, and Scilla autumnalis.* Whilst we were exploring about the Lighthouses, situated at the very sonthern extremity of England, we saw the Great Fasteru pass by, to take in the telegraphic cable. One is led to reflect here what a contrast in human affairs and human hearts occurs within a few miles. On the bare but picturesque promontory may be sauntering about elate excursionists or naturalists, or quiet countrymen, many, perhaps, with no thoughts beyoud to-day or terra firma, though others may think of absent or lost ones. Their last glimpse of their native land was this promontory. Of those every day passing these Lighthouses, what varied characters going or returning! - some with hearts joyous in hope, others with them depressed with disappointment.

But to leave the melancholy - what solitude is too remote for the tract distributor to penetrate? I received one from a puritanic-looking man in Kynance Cove, with an injunction to read it for my good. I promised to do so as I went home on the coach, and wandered on. Presently up came a cholericlooking gentleman, nervously fingering his cane, as if inclined to use it, and demanding whether I had just before given his son a tract. I said I had not, but if he himself would like one he might have mine, as I had just been presented with one, and did not care mucl about it. I saw he was in no humour to be joked, so walked on. A walk from the Lizard

* To these may be added on a young friend's authority, resident a Helston, Trifolium incarnatum (pale yellow rariety), Vicia lutea, Ophioglossum Lusitanicum (?), and a species of Hypericum, probably new to England. Trifolium Boceni occurs at Cadgwith, and Apium Eraveolens at Gunvalloe. 
Lighthonses, along the western coast, leads to the cove just mentioned, a picturesque spot, as is the whole coast here on both sides of the promontory; for when are shore, and rocks, and sea not picturesque? The climbing, however, if the walk is not more inland, is awkward and difficult, as my companion's broken shin testified. Maritime plants, as Samplire and Sea-starwort, occur; and quantities of crustaceans are taken here, particularly the Corwich crab, which is principally eaten by the poor. The little island opposite the cove is ealled Asparagus Island, and has one or two blow or spout-holes upon it; but the plant from which it is named is now more common at Cadgrvith. Into the cove itself a fine sand is driven in summer, to disappear again the following winter; numerous Medusidæ (Thaumantia), are lying upon it, just laid bare by the retiring sea. The Dropwort (Spircea filipendula) and Cladium mariscus are found above. I got specimens of serpentine, green or mottled with red, the latter colour due to chromate of iron-too cheap an article, however, to pay for extraction. Steatite or soap-stone also occurs in abundance, as well as diallage, mica slate, and homblende rock. On returning, we stayed some time at Helston. Goonhilly Downs, between this place and the Lizard, were formerly celebrated for a breed of horses-no doubt remarkable for thriving well when removed to other pastures, for they could not well have worse. Helston had formerly its castle, priory, \&c., but contains little for the antiquary now. Loe Pool is a picturesque and remarkable sheet of fresh, or occasionally brackish, water, below the town to the west; a bar ordinarily keeps out the waves of the sea. The rare strapwort, Corrigiola littoralis, grows on its banks, also Centunculus and Littorella; 
pond-reeds and white water-lilies are also seen in it.*

This excursion to the Lizard accomplished, we confined ourselves to the exploration of the promontory proper, west of Penzance. To get to the Land's End, one first has to traverse a pretty and fertile valley, with rivulet, cottages, orchards, luxuriant little fields, bridges, mills, ferny banlss, and umbrageous trees. Several wayside crosses occur on the road, the oldest kind having flattened shafts and circular heads, on which is carved the equilimbed Greek cross. Other stones about Penzance appear of later date, and are intaglio with a Roman cross or a crucifix. One of the ancient form, having the shaft also carved, stands ugainst the Town Hall at Penzance. Sancreed, a village near our present route, has an ornamental one of the later kind, and some say the village derives its name from the cross. As we leave the slate, and get on the granite, the country becomes barer and heathy, the commons affording little provender for cattle, though plenty of honey for bees. There was a great pillar of granite in a field to the right, and a little furtler on, in a gorsy field at some distance from the road, on the left hand, is the druidical circle of Boscawen-un, having originally nineteen stones, the same number as in anotlier circle which I afterwards visited; here there is a taller one in the centre of the circle. Further on, at Crouza-ura, is another cross, as the name signifies, also the burial-place of some ancient nonconformist sect-saints or heretics. The tuwn or village of St. Just lies to the right, named from Justus, the companion of Augustine. It has

* About Helston also may be found Hypericum calrcinum, Euphorbia platyphylla, Petasites fragrans, and Anchusa officinalis. 
its literary institute, and an amplitheatre or plananguares, 126 feet in diameter, with six tiers of seats. A friend on one occasion lectured here to the miners, who paid him in a norel way, viz., in rare minerals from Botallack and Levant.* On the right were some barren hills, one called Cairn Brea; to the left, in the midst of an open country, is seen the remarkable and high tower of St. Burian's church, which we visited on another occasion. This was formerly an important ecclesiastical structure, with a foundation from Athelstan, bestowed after a victory over the Cornish at Bollert, and is now the seat of a deanery. It has two crosses without, and within carved woodwork, and a Norman inseription on a tomb to Clarice, the wife of Geoffry de Bollert. Sennen is next passed, having also an ancient church, old cross, a table-men or -stone, where some very eminent individuals in very ancient times once dined, and also the inn with the well-known sign, "The First and the Last Imn in England '-only be it known there is a better one further on, at the very extremity of the Land's End. St. Sennen, from whom the village was named, was an Irish saint, who visited the Cornish. Upon our visit to the Land's Fnd, the day was cloudless, and the water perfectly calm, very different from its usual state in this exposed spot, where giant cliffs are lashed by the waves of the Atlantic, driving the surge even higher than the top of the Longships Lighthouse, wlich is situated on a rock a good mile from the Cape. As is often the

* At St. Just occur isonyre, specular iron, jasper, jaspery iron ore, native bismuth, massire grey copper, tourmaline, and white cobalt. At Botallack, native copper, arseniate of iron, sulphuret of bismuth, black hæmatite, massive ritreous copper, hydrous oxide of iron ; and at Levant, arragonite, crystallisod vitreous copper, and grey sulphuret of ditto. 
case in very fine weather, there was a haze over the sea, preventing our seeing the Scilly Isles, eight leagues distant. Tradition says they were once joined to Cornwall by a country called Lyonesse, having woods, towns, and churches upon it; but that was in the days of King Arthur. The Seren Stones, and the dreaded Wolf Rock, are traces of the tract in question. We explored the cliffs for a mile or so northwards: they present curious pinnacled forms of rock with caverns, one of the former called the Irish Lady, another more round-headed and reclining, and well crowned with hoary lichens, such as Roccella, bears the name of England's celebrated lexicographer, Dr. Johnson. Crossing a marshy hollow, we came upon a viper, on the look-out for a frog or bird. The heaths, too, abounded with insects, several pretty Lepidoptera, and a beetle, Ctenopus sulphureus, which was new to me, of a yellowish green tint. The Dodder abounded here, as elsewhere in Cornwall, and the Dwarf Gorse was just flowering. We came down to Semnen Core, and I was anxious to get on the Cowloe rocks, where the Balanophyllia regia is found. I searched for it an hour or more, but unfortunately the tide had just turned, and had become rather unfavourable. These shore rambles are only successful at spring-tides, occurring about new and full moon, and low water is not always available more than once in the twenty-four hours, unless the days are long, and one's limbs robust. The water was exceedingly clear, and the rocks corered with the common animal forms. A chapel here has been converted into a cottage. Before us lay the sweep of Whitesand Bay, and further on in the distance was Cape Cornwall. We could see on it one or two engine-houses orerhanging the sea, and at some distance seawards were 
the Brisons Islets, the dread of mariners; seen from this point they look as one isle. The sand of the bay is almost entirely composed of shells, mostly comminuted, but nevertheless affording a numerous series of species when well examined. A fisherman was carrying some enormous crayfish over the sands, for which he asked a shilling each; to our taste they were sweet and pleasant, but there is a sad deficiency in the want of claws-all tail! The seine-net is used here for the pilchards.

From the Land's End southwards is the grandest part of this coast. The Armed Knight, a towering insular rock; Enys Dodman, an arched islet; Pordenack Point, rising perpendicularly a great height above the sea, and having a portion of granite poised, as it were, on one of its prismatic pinnacles; then numerous carns or promontories, coves and caverns, named zawns here, but hugos at the Lizard ; Nanjizel, a picturesque cove; the Bosistow Logan, and other curious forms of rock, due to the weathering of the granite and to its peculiar intersections, vertical and horizontal, causing a cubic or prismatic arrangement, continued for some miles after turning the southernmost point; this point, Tol Pedn Penwith, having ladder-like cliffs of granite, and two beacons at its summit pointing to the dangerous Rumnel Stone, about a mile and a half from the shore; also a cavern opening both to sea and land: such are the objects so far. A little further is Porthgwarra, a curious fishing cove with tunnels in the cliffs cut for the convenience of getting down to the beach. St. Levan's village is situated further on, and half a mile inwards, worthy of notice for its two crosses, for some remarkable carving's of early date at its church, and for its holy well in a 
glen near the sea at Porth-chapel. Further on still is a remarkable promontory stretching into the sea, ending in some pinnacled rocks with the structure already alluded to, called Castle Treryn, and having entrenchments at its base or neck, such as often occur on the Cornish as well as the Welsh coast. Here is the true Logan stone. Looking down to the right, one sees Pednvounder Cove and Porth Kernou. The latter has a ruined chapel. The rocks just here are difficult to descend or to climb, but the views are fine when either is done. Below is a beautiful beach of shell-sand, which ceases on the other side of the promontory. Rock basins here occur in different stages of their formation, due no doubt to natural decomposition and the disintegrating action of infusoria. The shell-sand is prolific in minute forms of shell life. Numerous rare fish have been taken off these rocks - the white shark, bonitos, the derbio, the sting ray, the painted ditto, the scabbard-fish, the great weever, and the black-fish.

Three or four days of quiet walking eastwards, northwards, and westivards from Penzance, sufficed to explore much of the remaining topography, antiquities, botany, \&c., of the peninsula forming the district of the Land's End. The eastwaird walk was to St. Ives and its bay, the town looking a good deal like what one can fancy, or what one reads of, a southern littoral one; it is built partly upon the shores of a little bay crowded with vessels, and partly upon what is called the island, but which in reality is a rocky promontory or peninsula stretching northwards into the sea. From this last point the north coast can be traced westwards for a short distance only. On returning to Hayle we visited a mine to the left of the road. Tin-getting must be miserable work, rough and 
wet, but the men, unlike colliers, have dresses worn only in the mines, with a comfortable room to change and wash. The women engaged in ore-washing were remarkably clean and well-dressed, with superior air and manners besides. Along the low bushy cliffs on the west margin of St. Ires Bay the true Maidenhair (Adiantum) grows, and we picked several small roots of it. The tide was out from the broad sands, or we should have boated across the bay's mouth; as it was, we had to walk to Lelant Church, situated on some sand-hills higher up on the estuary. It has some Anglo-Norman architecture. Besides the Maidenhair, there were other plants along the shore, and we noticed the Gladwyn (Iris foetidissima) parasitical, high up on the stump of a tree.* At Lelant we crossed the river by a ferry, and then walked over sand-hills or towans to Phillack. On these towans Arundo arenaria is said to be purposely planted, to bind them together. Cochlearia and Convolvulus soldanella also grew amongst the grasses, and tine ground was covered with multitudes of small shellsnails, Helices and Bulimi, upon which it is said that such sheep as feed fatten well. I now made the best of my way northwards along the east side of the bay, the sands being often bad enough walking. The Soapwort occurred by the roadside, also a handsome Broom, which I take to be the Spanish or Rushy Broom, Spartium junceus, not considered indigenous, but here certainly holding its own without help. I passed some mines, which seemed to have been a bad speculation, from their deserted look; then through some fields very gay with Salvia, Scabious, Poppies, Centaury and Jasione, to Gwineath. Near the church

* Dianthus armeria, Hypericum montanum, Orobanche barbata, and Statice Dodarti also occur. 
was a fig-tree, the lieight of a moderate-sized louse. Several others occurred along the roadside, unappropriated to any house or garden at present existing. By the side of a stream on a sandy plain were the walls of an ancient chapel, which had been exhumed by digging away the sand it was said-a similar building to that of Perranzabuloe, further east on the same coast. Both sides of the British Channel seem particularly liable to the inroads of these sands, forming what are called burrows on the Welsh side, torvans on the Cornish. No more remains of the chapel than the rude walls of the nave and chancel with a doorway; one of its rafters, however, lay inside amongst some common and noxious weeds. Hayle is one of the busy workshops of manufacturing men. The muddy shallow of the wide rirer presents many gay clumps of the Sea-aster. It is near the site of the Bossens of Britannia Romana.*

Another walk was westwards along the coast till I attained Penberth, a fishing cove not far from the Logan rock already mentioned. Newlyn and Mousehole are noted fishing villages on the way, west of Penzance. At the latter is a cavern supposed to give the village its odd name. Its entrance is beautifully festooned with Asplenium and other ferns, but I nearly got a dangerous fall in descending to it, laving taken the wrong direction-a young woman of the village hard by (but a bad specimen of it) watching. me without putting me right. A little inwards is the village of St. Paul, some say dedicated to St. Paul de Leon, who was a Cornish man, others, and more probably, to St. Paulinus. Some rare plants may be picked about these villages, and the rocks and

* Tencrium chamædrys, Glaux, Schoberia maritima, Euphorbia paralias, E. Purtlandica, and Rottboellia occur here. 
caverns abound with Algæ, Hepaticæ, and lichens; in fact there is a very plentiful harvest for the lichenologist all a ng this part of the coast. St. Clement's Isle lies a little way off Mousehole, and on another occasion we spent one ebb of the tide there, the boat moored to the rocks, and the boys who rowed it passing the time asleep at its bottom, with their legs dangling over the gunwale, instead of assisting us in our search for crabs and sea-anemones. The Spaniards in their palmy days often made descents on this part of the coast. At Lamorna, further on, much granite is quarried, and there is a pier for the shipment of it. After passing St. Loy's Cove, the rocks become more picturesque in their features, and there is a fine walk over the heathery hills and along the lichen-covered cliffs to Penberth, a picturesque spot with several cottages, the shore so steep that the boats are drawn to land by a capstan and secured to rings in the rock. The promontory further on is called Cribba (crested) Head. A fisherman was starting with baits for bass and whiting and rauning pollack. He demonstrated how crabs cast off a claw at their pleasure at a particular point with impunity, and said that they would die or waste if it were torn off at any other point. They will cast one off if it is held a short time, or if it is injured by pulling off the last joint, and, after inverting it, thrusting it into the next joint! Here I turned back, and shortly crossed, more inland, one of the streams which I had seen fall into the sea. There were numerous caverns in the granite breccia, of which most of the surface seems to consist; their obscure recesses were resplendent with the delicate little pinnate-leaved moss, the Schistostega. Further on are passed several crosses, one having a crucifixion cut 
on it, also several other upright stones. Red graphic granite appears here. The curious IIentha rotundifolia occurred on the roadside. The two tall granite pillars called the Pipers are seen to the left hand, on the road to Penzance, and there is also a remarkable cavern near. In a field through which the path leads is the druidical circle of Bolleit or Dawn's Myin, commonly called the Merry Maidens; it has nineteen upright stones, of which two are a little nearer together than the others, and have opposite to them within the circle a hillock or barrow. Bartzia viscosa grew within the ring, and in the next cornfield Silene Anglica was a prevalent weed. A poor tattered, muttering fellow, apparently half-maniacal with starvation, was passing through the circle on his way from a village at the Land's End - a modern Briton, as piteous to behold as would be the ancient half-naked and painted one. In some marshy ground further on was the Fern-royal, and also Drosera longifolia. My dinner this day was bread and butter and some mill, for which the farmer's wife would accept nothing. They treat their milk peculiarly. They also keep goats, and sometimes fatten their kids for the table.

In my walk northwards, or rather north-westwards from Penzance, I came to Madron village, after obtaining several fine views of the Mount and bay as I went along. I hastened on, after an outside inspection of the church, to St. Madron's Well, situated. further on, in some low marshy ground on the common. The building is unroofed, an oblong apartment, with a spring at one corner, and seats around. The pretty little Cornish Moneywort (Sibtho"pia Europcea) grew at the damp bottoms of the walls and about the well. It has been said not to thrive 
out of Cornwall, but it does well, and flowers under a bell-glass anywhere. I crossed some hilly fields and a common, and then got into a road which led past the Lanyon cromlech. It looked a strange object on the wild moor-a huge oblong table of stone, supported by three pillars. I sate down by it, grew dreamy, and half asleep, and was at last aroused by an awful sigh behind me, such as might have proceeded from the deep recesses of the mournful breast of an ancient Druid. I started, and saw that it came from a little red heifer which had crept up to have a smell at me. On the road during the hot day my hands were several times bitten by a fly (Musca calcitrans), and the bites afterwards inflamed and continued troublesome for some days. At a hamlet further on I turned on to the common to the right, and, after a good deal of searching, came across the Mên-an-tol, three stones in a line, of which one has a hole through it, hardly attributable to the weathering of the granite. Some say this monument was for oaths, others for surgical treatment, like the split ash of other parts of England. Half a mile further I found the Mên Scryfa, or inscribed stone, and on it may be easily read 'Rialobran-Cunoval Fil.' There is a similar one at Bleu Bridge, nearer Penzance, inscribed 'Quenatavus Icdinui filius.' Both are remarkable vestiges of Romano-British days. Cairn Galva, a hill of rugged rock, lay before me,* and I also passed some ancient stream tin-works with great excavations in the ground. Ding Dong, a very ancient mine, was a little to my right, having the remains of a stone circle near. A little further on is the sea; and there is a fine promontory jutting out into it,

* Polypodium phegopteris, Hymenophyllum, and numerous lichens, as Sticta crocata, grow at Cairn Galra. 
called Gurnard's Head, having a ruined chapel dedicated to St. Helas, and a holy well at its base. To the right also is Zennor, where is a cromlech; the name is said to mean 'holy land.' Its church contains some ancient carved work. There is also a cromlech at Moelfra. Gurnard's Head and the coast onwards to St. Ives are of schist, but the granite appears again westwards at Porthmear Cove, the influence of the nature of the geological formation being curiously displayed in the form of these promontories and rocks; several of them have ancient entrenchments upon them. As I stood on the northern declivity of Choon Hill, the village of Morvah (place by the sea), with its church, lay before me, whilst the northern or Bristol Channel stretched out far beyond. Nearer to me was another cromlech, composed below of a box of four stones with a lid. Near also was Pendeen, its notabilia being a cavern, and its association with Borlase. Close at hand are the mines of Botallack and Levant, interesting to mineralogists and engineers, as is the surrounding district to the botanist, who finds here two rare plants, the Golden Samphire, Inula crithmoides, and Hypericum linarifolium, a Lusitanian species. Both the mines named are worked under the sea, and are situated upon a long littoral strip of schist, stretching from Cape Cornwall to Pendeen, near Morvah, where the granite already alluded to again borders the coast for two or three miles, often putting on the form of rounded and piled tables, thus constituting he curious rocks. Choon Circle, or Castle, is situated on the top of the hill on which the cromlech stands, and on the north side of the same lill are many cairns of stone, and also remains of British huts. There is a double ditch and double wall of loose stones round the summit of the hill, and an entrance 
at one point of the circle. It must have been a kind of pah of great strength, probably increased by wicker-work; it would be formidable even in our times. I paced the interior up and down, in hopes to pick up a fragment of flint or some slight token of those who once occupied the 'castle,' but in vain. Nay, here is something odd! A fungus or mushroom? Only a champagne-cork of some modern Briton. I missed seeing the well which exists in the enclosure. A fern-owl was sitting on one of the stones. At Castle-an-Dinas, on the left of the road from Penzance to St. Ives, is a similar castle or camp to that of Choon, but not so perfect, and there are several other traces of the same circular fortifications in the neighbourhood of Penzance. I passed by the Cairn Kenidzhek, a place to which several strange and fearful legends are attached, and where also is another camp and some barrows, whence urns and other remains have been extracted. There was no inn in this district, but some milk refreshed me at a cottage on the heath. Even from this wild spot the master had tried his fortune in search of gold at the Australian diggings, and had returned home apparently none the richer. My walk back was through some pleasant fields, and then over a common to Trengwainton Cairn. Here were some mine-workings, and I passed a cross of which the shaft formed a sort of Logan stone to the hollowed pedestal. Hieracium umbellatum, a plant, however, pretty common, occurred on the roadside, and Fontinalis squamosa in the pools. I got back to Madron again, after passing through a grove of pine.

* A species of Cynips deposits its eggs at the top of the stem in this plant, about which galls are afterwards formed; these remain through the winter, and the following summer the perfect insect comes forth. 
The Lord's Prayer and Creed in Cornish are given by Camden, and we may on the same page compare the language with Welsh and Armoric. Cornish has now, for nearly a century, been a dead language, understood only by a few linguists, and indeed it has very few fragments remaining. It continued a spoken language at the Land's End last of all, but the people there now speak good English, with an intonation, however, somewhat like that practised by the Welsh. Lhuyd published a grammar of Cornish in 1707 , and there are other similar introductions to it. There are also one or two ancient Cornish dramas or mysteries extant in the Bodleian, \&c.- one on the Passion, and another, Gweans au bys, a mystery on the Creation.

The folks themselves, like the Welsh, are generally rather short, tolerably handsome, but the mouth rather wide and coarse, and the cheek-bones high. The complexion is brilliant enough, and they have generally dark and luxuriant hair; their eyes also are generally dark, but sometimes light grey; upon the whole their ethnological characters seem of the Celtic type, with apparently a considerable admixture of foreign blood, more than exists in the remote Welsh. The Cornish, indeed, have been supposed to have an admixture of more than ordinary outlandish blood. That the Plinicians came here for tin is certain, but no antiquities attributable to them and indicating a residence have been found-it is said, indeed, in no part of Great Britain or Ireland. The Cornish have a tradition of Jew metallurgists ; and the names of some of their places appear to be of a Jewish complexion. These facts point to the same circumstance - the residence amongst them, either in ancient or in comparatively modern times, of Jewish merchants, 
or of those who were considered to be of that nation. The fishwomen invariably carry their baskets or cowells on the back, with a band over the head. The labourers dig with the Celtic spade, having a long and curved shaft, without the cross or looped handle generally seen, and appear to use the formidable tool well: the shape is like an ancient British paddle. The women at present wear gowks, or large sun-bonnets, when labouring in the fields; but we suppose, like other ladies, they worship the fashion of the day. Their houses look dark, owing to the thick walls and small windows, but they must be warm in winter, and fuel is scarce, often consisting only of dried gorse or heath. They are often formed below of large granite stones or slabs, and above of mud from the granite detritus, but they are whitewashed, and evince a taste for cleanliness in the owners. Generally the people are well off, but perhaps this remark will not apply to the remote villages. They are enterprising in mining affairs, imaginative, rather superstitious, fond of open-air preaching. There were five or six thousand congregated at a preaching under our windows on a Sunday afternoon. Their voices are musical in singing, as are those of the Welsh. The names of places, of common utensils, and the terms used in husbandry and fishing, are remains of their ancient language, but much corrupted and very varied in orthography. The Cornish are naturally long-lived. In a Cornish paper of October 28, 1864, we read that at a baptisin at Sennen the parents of the fifth generation were present. The sponsors were one great-great-grandfather, one great-grandfather, and two great-grandmothers. The great-great-grandfather has still living. two brothers and one sister; their united ages being 
340 years. This longevity unfortunately does not apply to the miners, whose lives are shortened from accidents, and also by their employment in hot and impure air. They often lose by perspiration five or six pounds in eight hours of work. Cornish men, like Devonians, excel in hurling and wrestling, and in their clotted cream.

The natural history of the Land's End district is nteresting, as already observed. It has a number of flowering plants not found in other parts of Great Britain; some of them, however, shared with the Channel Islands or with the south of Ireland-they evidently belonging to southern, or rather southwestern Europe, or to the Lusitanian province rather than to the Celtic. One naturally philosophises on the subject. How is it that lands so far parted by seas have, when latitude, longitude, and other circumstances agree, the same plants? Were such localities once continuous? and can their severance or discontinuity have taken place in such comparatively recent times, as one infer's must have been the case? Was the origin of the plants independent of all geographical continuity, and solely coincident with climate and similar circumstances? Then we must recollect the possibility of the propagation of plants from one shore to another by currents, birds, winds, and other similar causes. The peculiarity of the Cornish Flora probably holds good even with respect to the lower forms of vegetable life, though the general distribution of many of these may not be sufficiently well-known to close the comparison. Trichostomum funcle, found on the rocks at Tolcarn, and Bryum Tozeri, found near Newlyn, are mosses peculiar to the south-western coast. Hookeria latevirens is an Irish form occurring here. Several mosses, however, 
commonly considered as subalpine forms, are also found, * with some other rare species. $\dagger$ There are also Irish forms of Jungermamnix + and of Lichens. $\$$ In these latter Cryptogamia, Tol-pedn-penwith, Lamorna, the Lind's End, and indeed all the rocks around the district, often enveloped as they are in the damp mists of the ocean, abound, and several of them are peculiar to the district, or at least rare elsewhere. Other interesting forms of lower vegetable life || have had habitats in the district indicated, especially by Mr. Ralfs, many of which are of especial interest to the microscopist. We got a few rare specimens from the pools at Trengwainton.

A deficiency of wood and of rivers characterises the district, and accounts for the absence of some forms of animal life. The Scilly Islands are said to want both snakes and toads. We have already mentioned the viper as existing at the extremity of the Land's End. The otter feeds on the coast; the badger is not rare on the commons; there are few woodpeckers, but the kingfisher is not absent, though another river bird, the dipper, is much rarer than in the next county. Many of the Balænidæ are made out to frequent the coast; also the seal.

The rapacious birds are fairly represented, as might be supposed from the prevalence of wild moor and rock; such are the osprey and the peregrine falcon,

* Andrea Rothii, Anictangium ciliatum, Pterogonium gracile, Diphyscium foliosum, Zygodon conoides, Entoschodon Templetoni.

$\uparrow$ Hookcria lucens, Daltonia heteromalla.

$\ddagger$ Jungermannia Iibernica, J. Ralfsii, J. Mackaii, J. calyptrifolia.

\& Lecanora milrina, Lccidea stellulata, Parmelia diatrypha, P. speciosa, Borrcra leucomela, B. flaricans, Roccella fuciformis, and R. tinctoria.

\| Chara transhucens, Lemania fluriatilis, Batrachospermum ragum, B. moniliforme, B. atrum, Cladophora Brownii, Conferva mucosa, Zygnema currata, Mongeotia, Stigonema, Oscillatoria, Meloseira nummuloides, and others. 
which latter breeds in the cliffs. The nightingale is absent; also, it is said, the redpoles; and the whinchat, curiously enough, is rare; as is also the black grouse. Some little warblers, as the reed-, garden-, and willow-warblers, are not numerous, occurring principally during migration; and so with the treepipit and the wryneck. Some summer birds of passage occasionally stay the winter at the Land's End; others appear very early or stay very late. The yellow wagtail and the starling do not breed here. A friend procured the egg of the woodcock at Helston, and newly-hatched snipes are seen in the district. The Land's End also shares with the Scilly Islands in the visits of many rare birds, peculiarly continental, but driven out of their usual course of migration, or otherwise lured by fineness of climate; such are the roller, the bee-eater, the golden oriole, the rose-coloured pastor, and others. The raven occurs; the hooded crow and the Cornish chough are now not common. Camden accuses the latter of being an incendiary. There is a specimen of the stork in the Penzance Museum, killed at Sennen Pool. We do not see the great flocks of sea-birds here as at some other places, though they are numerous in species. Many breed at Bosistow, Dollah Rock, and Mullion Island; but the Cornish coast is rather a feeding than a breeding ground for them, the Scilly islands offering greater attractions. The greater and Manx shear-waters have been taken in Mount's Bay. The stormy-petrel breeds at Scilly, and several other rare species of petrel occur off the Cornish coast. The gannet occurs, but does not breed here. One feels indignant to witness the destruction made by the fowler's deadly gun amongst these beautiful creatures; unpardonable when induced simply by a wanton love of sport. Fashion has now found a use for 
the plumage of gulls and other birds of the sort-the adornment of ladies' hats-unfortunately for the poor birds. Whilst picking shells, star-fish, and sea-anemones off a rock on the coast, I most days noticed a sportsman stationed behind a high cliff, dealing death amongst the poor gulls. If I had expostulated. he might have retorted and told me he was an ornithologist, or at any rate asked me what I was doing, and no doubt collectors of less vitalised creatures than birds are sometimes too profuse in their takes.

The Cornish coasts abound with species of fish interesting to the ichthyologist, some indeed peculiar. Several naturalists, Jago, Borlase, and others of our own times, especially the Messis. Couch, have been industrious observers of them. Few British species are wanting in the Cornish list, and these few are principally northern species; on the other hand, numerous Mediterranean, southern, or even tropical forms enter into it. Amongst the rarities of the Percidæ, found at this extremity of Cornwall, occur the dusky serranus and the wreck-bass, the latter being often found near portions of wreck or floating timber covered with Lepades. The surmullet is a favourite fish for the table, peculiar in flavour, especially its liver; the red mullet is rare, but the golden mullet occurs. Amongst the gurnards are the streaked, the spiny, and the curious mailed species. Amongst the Scomberidæ, the rarest are the Spanish mackerel, and several of the bonitos and tunnies, the common tunny, the long-finned ditto, the plain bonito, the striped ditto, and the alolonga; the latter fishes often pursuing the pilchard and skipper. To these southerners should be added the hair-tail, the swordfish, the black-fish, and the pilot-fish; this last often following in the wake of vessels. The ceil coning, or oared Gymnetrus, a curious East Indian species, 
has occurred. Sereral of the rarer blemnies and wrasses are from this coast. The trumpet-fish has been caught in Mount's Bay, the greater flying-fish has been often seen, and the Hemiramphus has several times occurred. There are also rare Gadidæ. The little Cornish sucker seemed common at St. Clement's Isle, adhering by its curious disk to the finger when handled. The muræna has occurred; the morris is pretty common, and all or most of the pipe-fishes. Pennant's globe-fish, and both the sun-fishes, are obtained on the coast. A large maigre, about a hundred-weight, was taken this year (1864), near the Longships, and the Spanish and Ray's bream occur. The white shark is very injurious to the fishermen by tearing their nets, and some others of the armed dog-fish and rays occur, and are awkward to come in contact with. The becker, the tadpole-fish, the cuckoo rays, and the formidable fire-flair may be mentioned in the list. The little fish, the pilchard, is a greater boon to the inhabitants than all the rest of the finny tribe put together; at the present time it is taken in two ways, by the seine and drift-net. The former in certain localities is a murderous enough trap, reminding one of the tunny fishery of the Mediterranean. The increased facilities of transit have wonderfully added to the importance of this fishery as a source of wealth. Most of the fish taken, however, are salted in cellars, and exported to Roman Catholic counties for Lenten diet.

Hoping to get an outing or two with trawlers, my dredge was left at lome; but therein I was disappointed, for the pilchard was just making its appearance, and monopolised the attentions of the fishermen. The harvest of the sea and land begins about the same time. I was confined to shore-hunting 
(mud-larking my friends term it), upturning stones, netting for Medusidx, and also throwing out and dragging in a small hand dredge, either on shelving rocks or amongst the little fields of sea-weeds seen in shallower water. Of spiral molluses several northerm species seemed rare, as Fusus antiquus, Trophon clathratus, and Turritella communis. On the contrary, we found Murex erinaceus, Nassa reticulata, and the pretty Cyprcea Europaca, all common enough; also a pretty white variety of Trochus zizyphinus. A small Doris occurred on the rocks, and I took Natica Alderi and sereral Nuculæ from the stomach of Asterias aurantiaca, which was brought to me. The pretty. cephalopod Spirula, as well as Janthina communis and exigua, are occasionally driven on shore; for the occurrence of the former Mr. Couch is the authority. A prolific source from which to obtain many of the minute forms of rare shells is the shell-sand, particularly of Whitesand Bay and Portheurno Cove.* Between tide-marks, and, still better, lower down at the spring-tides, amongst the Laminarix and other sea-weeds, are many small shells to be found upon a careful examination. $\dagger$ Others occur still deeper upon coralline ground, many of them southern species. The interesting Marginella locvis and Ovula patula occur at the Land's End, but are rarer than the Cypræa, though allied to it. Bulloca aperta was brought to me. $\ddagger$

* Trophon muricatus, Plourotoma sinuosa, Aclis unica (Hayle), A. nitilissima, Rissor (semicostata, \&c.), Trochus strialis, Emarginula roticulata, Pileopsis Hungaricus, with other species.

† Lachesis mirima, Mangelia costata, Cerithium reticulatum, C. adrersum, Odostomia cylindrica, Fulima polita, Rissoa crenulata, R. fulgida, R. ritrea, R. costata, Skenea rota, Amphisphyra hyalina, Cyclidium truncatum, C. obtusum.

+ The following are rare and intoresting:--Scalaria clathratula, Littorina mamillaris, Turbo jugosus, Phasianella, Tornatella fasciata, 
Helix revoluta, a rare land shell, is found in the district, and H. pisana occurs on Eryngium maritimum about the promontory at St. Ives. Conovulus denticulatus, Acme lineata, Lymnous glaber, and Planorbis glabra, are also found.

But to return to marine animals : the Conchifera or bivalves found on this prolific coast are also numerous and characteristic-many rare and interesting. The rarer scallops found are Pecten varius, trigonus, and similis, the latter attached to Pinna shells. The locality for Pinna rudis is Porthcurno Cove, but it is said to be most abundant six or eight leagues south of Dodman Point. Crenella castulata occurs, Arca lactea and tetragona also, in crevices of stones from deep water. Cytherea chione, or queens, a handsome Lusitanian species, occurs at Hæyle and MiTount's Bay ; also Lucinopsis undata and Mactra helvacea at the former place. Cyprina Islandica is here a rare shell. Isocardia cor occurs at Helsford. Several species of Teredo have been indicated. Valves of Lutraria were strewed about in St. Ires Bay.*

Balanus tintinnabulum was found by Mr. Couch on the nidus of the whelk. Pyrgoma Anglica is found on the stones in Mount's Bay. Anatifers occur, as elsewhere, on floating timber, feathers and sea-wreeds. Polliceps scalpellum more truly belongs to the coast.

Of Crustacea a great number of species occur, many rare, others peculiar to this locality. We found the rocks and large stones at St. Clement's

Scaphander liguaria ; some southern forms of Trochus, T. exasperatus, striatus umbilicatus, and lineatus; also Dentalium tarentinum and Chiton marginatus.

* Add Lima Luscombii, Cardium fasciatum, and Ervilia castanea; also Artemis triangularis, Circe minima, Tapes virginea, Tellina donacina, T. crassa, T. pygmæa, Psammovia tellinella, Donax pulitus, Cochlodesma protenue. 
Isle to afford many. The little gulf-weed crab has been taken, and several rare species secured by examining the stomachs of fish, or from the crab-pots.*

Of the Echinodermata we got Echinus esculentus and miliaris from pools and from the rocks at St. Clement's Isle. Adophyton scutatum was first found in Cornwall by Borlase. Luidia fragillissima, Asterias cartilaginea and Johnstoni are taken in deep water. I found $A$. yibbosa common enough on rocks in the bay, and for the first time picked $A$. glacialis, also common here. A. spinosa is recorded. Comatula rosea occurs, and C. barbata in crab-pots.

Gorgonia verrucosa, or the sea-fan, occurs at different depths along the coast; also G. flabella. The madrepore Caryophyllia Smithii occurs on the Cowloe rocks and in other places; also Balanophyllia regia. Both are beautiful and remarkably hardy in the aquarium. Zoanthus Couchii is also pretty common in deep water. I noticed the mutilated fragments of a Medusa of a deep purple colour lying on the shore at Penzance in profusion.

Amongst the sea-anemones we picked Actinoloba dianthus, Sagartia viduata, S. bellis, S. parasitica, S. fragacea, S. rosea, Anthea cereus (some richly coloured), Bunodes gemmacea, and B. crassicornis, highly tinted. $\dagger$

Of the sea-weeds found on the coast, many are

* It would be difficult to epitomise tho labours of those who have huntod out the Cornish Crustacea, foremost amongst whom occurs the name of Couch.

$\uparrow$ To these should be added Actinia Templetoni, Sagartia miniata, S. renustata, S. troglodytes, S. sphyrodeta, S. nivea, Bunades Ballii and Corynactes viridis. To these may be subjoined the following:-Bryozon, Crisia setacea, C. chelata, Anguinaria spathulata, Tubulipora fungia, Celleporn læris, Retepora reticulata. Of the Hydrozoa sereral rare species are found adhering to Pinna shells, Gorgonia, and the Corwich crab. 
rare, some peculiarly southern-Nitophylla, Rhodomenix, Polysiplonix, Ceramix, Callithamnia, Cystoseriæ, Asperococci, Spherococci, Sphacelariæ, \&c.*

The basis of the Cornish strata (to finish the chapter with a little geology) one would suppose must be granite, yet this is seen to send veins upwards through the other rocks, therefore such protrusion must be secondary to the deposit of these apparently superincumbent strata. The granite is generally whitish, rarely with its felspar basis reddish. Often the felspar is in large crystals, and this spoils the stone for building. About the Land's End the granite is less decomposed than in the china-clay district to the east. The granite, as seen in Cornwall, occurs in several hummocks or bosses, which are surrounded by the killas or slate. For the latter it does not quite appear what name the geologists have agreed upon, nor what age they would assign to it; but it, as well as the granite, is cut through by certain dykes of igneous porphyritic rock called elvan, which run generally east and west. At the extremity of Cornwall there are the Land's End granite, a small tract at Breage, and a still smaller at St. Michael's Mount. The Scilly Islands are also of granite. It sometimes puts on the gneissic form, and schorl or tourmaline and quartz veins occur in it at Lamorna, St. Paul, \&c. Gold has been found in the granite, either in situ or in its detritus. Native silver is considered rare. In the elvan, whose dykes mark

* Add also Rytyphlæa complanata, Bonnemaisonia asparagoides, Chylocladia parrula, Grateloupia filicina, Kalymenia Derbyii, Chondrus Norvegicus, Naccaria Wigghii, Crouania attenuata, Microcladia glandulosum, Fucus tuberculatus, Dichloria viridis, Punctaria plantaginea, Padina deusta, Ectocarpus sphærophorus, E. pusillus, E. Hinksiæ, Codium adharens, C. tomentosum, Chætophora pellita, Enteromorpha erecta, Ulva furfuracea. 
the situation of the great mines, axinite and actinolite occur. Again, some varieties of gems are found in the granite, but unfortunately we found none of these precious things, save only a few mean garnets. At St. Michael's Mount the granite veins may be seen in the killas; at the Lizard they penetrate the serpentine and hornblende and mica-slate rocks. The term 'growan' more particularly applies to the decomposed granite used in the crude state for grinding for porcelain, and called Cornish stone. Mineral veins are evidently most prevalent at the junction of the granite and the killas. Copper and tin occur in the primary reins running about east and west, but the tro metals do not often go together. In the cross reins lead occurs, with silver.

At the Lizard, the lowest stratified rocks appear to consist of mica or hornblende slate; but here there has been a great outbreak of serpentine, piercing. through and lying upon the other rocks, as may be seen in the enchanting walk from the Lighthouses to Kynance Cove. Diallage and steatite are associated with the serpentine, the latter giving a white appearance to the cliffs in places. One rock is called the Soap Rock, and indeed the steatite often looks and feels wonderfully like Castile soap. The white specimens are cut into brooches, birds'-eggrs, and other articles, but ornaments are especially made from the serpentine, as may be seen at the extensive works at Penzance. It is there sawn by machinery, or turned on the lathe, by the aid of stout instruments, and afterwards polished by crocus martis, \&c. Some specimens approach the character of noble serpentine, or of bronzite; the red veins or spots are due to cliromate of iron. Strings of metallic copper occur in the serpentine. 
No traces of fossils are apparent in the killas, at least we could find none; but we must confess that we are not in the secret respecting it. We suppose it is a water deposit, but much displaced in its stratification. It generally ranks as a member of the Devonian formation. The curious stream tin-works are deposits of gravel, sand, and clay, apparently of different ages; often, geologically speaking, very recent; sometimes situated on rather elevated ground, at other times in valleys or along streams. The deposits may even contain remains of man or his works, tools or arms in flint or metal, bones of deer and other animals, and vegetable débris. Traces of elevation and depression of the land are visible all around this coast, as elsewhere in England; raised beaches or shores on the land, now many feet above high watermark; and at low water traces of submarine forest, which are plain enough in Mount's Bay. In these facts traditions almost seem to make good their claim to have a stand-ground when we consider the more recent geological changes.

We were shown some unusually fine specimens of minerals; amongst others, uran-mica, purple copper, tabular carbonate of iron, blue carbonate of copper, splendid iron pyrites from Liskeard, tin pseudomorphic of felspar, and quartz with carbonate of iron. Phosphate of uranium, phosphate of copper, yellow phosphate of lead, arseniate of copper, and carbonate of lead are all considered rare at the present time. Peculiar Cornwall minerals are Condurrite, Strahlerz, crystalline buntkupfererz, tin pyrites, Bournonite, vitreous copper, and Tennantite. Other new ones occasionally occur, as we read in the journals. 


\section{CHAPTER VII.}

THE HIGHLANDS (A GLIMPSE OF).

THоб art a rugged but pleasant spot on the earth's surface, Caledonia! Where are mountains sterner and grander-where lochs and friths more lashed by the storm at one time, more smiling and picturesque at another-where wilder glens, more fertile straths? Many, too, are the localities which bring to our mind the events of bygone ages, penned, it may be, by him whose verses seem animated by the same spirit that hovers over thy wild scenery, and whose prose, though ranked as fiction, is but a little below history; so imbued was he with a knowledge of the men and manners of the past, and so gifted with the capacity of transferring himself back to those times. How one longs to climb thy mountains ; explore thy central forests and glens; circumambulate thy lakes, and wander along thy shores; to search out the rarities of Flora which grow on the borders of thy Alpine snows; to hammer and dig at thy stony veins, in order to obtain some idea of thy structure; to survey animal life, as it is seen on thy sea-cliffs, thy mountain moors, and thy sinuous waters; lastly, to search out memorials of the past in thy ruined fanes, thy mysterious towers, thy monumental slabs! But, alack! what can a Southron do? All on this side the Tweed, it is said, the Scot considers his own; what, then, for a foreigner beyond it? What can he hope to say of the land worth listening to, or what that the 
native has not said-and said well-before? All these serious points are confessed; we do but 'spy out the land,' we only enter it as a parvenu; we shall borrow from her own sons if it suit us, and at the same time shall join them in their admiration of their good land. Scotland's natural history, her geology, and her antiquities have never wanted students, and competent ones too; yet probably a more searching examination of her appertainings has still to be made-would that we could do it!

In the clead of the night we entered the railway carriage in the centre of England, to be whirled to Edimburgh for breakfast; luckily we had a carriage to ourselves, and with a carpet-bag for a pillow, and a rug for a blanket, we got to sleep, or at least into a state of semi-sleep; and that is acceptable in a long railway expedition, as it kills the weary hours. We were only disturbed by the entrance of a great flare into the carriage, from the Wigan collieries. Day dawned as the borders were approached, and pretty the valleys looked, with the never-sleeping rivers, the Esk and Eden; and also with the grand hills wreathed with rolling mists. As the Solway is approached, the landscape becomes more dreary, flat and mossy. No doubt we are in Scotland, for this is the Gretna station, where, however, nothing now seems likely to induce any one to stop. On through the Moffat Hills, a western prolongation of the Cheviots; one of them, Queensbury, passed to the left, being of a good height; they, as well as the valleys, look, generally speaking, very delectable, especially Annandale, whinh the railway, the road, and a river traverse; the rising ground on each side varied with a few enclosures, clumps of firs, and here and there pretty whitewashed cots, or, may be, farm-houses of 
cheerful aspect. Lead Hills is said to be the highest inhabited place in North Britain. In Annandale we had an alarm-a stoppage from an upset of goodswaggons before us. We had all to get out of the train and shove the offenders down the embankment - certainly with utter disregard of the value of railway property. The railway at Carstair's divides; to the left is the line to Glasgow, along the course of the Clyde valley; to the right to Edinburgh; and on we go to the modern Athens, leaving the Pentland Hills to the right. The country passed through is described by Mr. Geikie as, geologically speaking, an old sea bottom, the inequalities not produced by partial dislocations, but by sea action, the drifting of ice, and the subsequent ordinary operations of the atmosphere, of rain, frost, and so on. Further on, the strata change from old Silurian to Carboniferous, a broad band of which obliquely crosses the kingdom from south-west to north-east, and constitutes the main-spring of its wealth and population. Many are the eminences of igneous rock throughout this latter district, not formed by ejection into daylight, but having, from their harder nature, withstood the effects of denudation. The coal strata are a lower and more ancient set than most of the English beds, reposing on older strata than the Millstone Grit, and more abounding with marine deposits.

We gave the innkeeper in Prince's Street twentyfour hours to make the best out of us that he could, which he duly availed himself of, though we could find no fault with the appointments of the place; he very naively told us that his class prefer Englishmen to Scotchmen, and surely we ought to be thankful for that. But what can we say of our impressions of Edinburgh?-certainly that it is a place for its 
citizens to be proud of. We climbed Calton Hill, admired its superstructures, and knocked off specimens of its rock; that, and the one on which the castle is built, and also Arthur's Seat, being of that igneous formation alluded to just above. We cast the eye towards the river, but thought its distance from the city an imperfection-a circumstance, however, shared with the ancient Athens, as well as with many other cities; to the south-east were the Muirfoot and Lammermuir Hills ; but the view of Prince's Street is the most noticeable, with its several objects, Scott's Monument, the Royal Institution and National Gallery, the gardens in the hollow of North Loch, and the Castle in the distance. More to the left was Holyrood; and further on, Arthur's Seat, with its buttress of Salisbury Craigs. We now bent our steps to Holyrood, looked over the portraits in its gallery, thought of Mary and Darnley, and lingered in the old chapel; next we went to the University Museum, hardly worthy of that once especially-and still moderately celebrated seat of learning; we searched out the wynds and houses of the old town, threaded. the intricate Fish-market, and surveyed the fishdames; we perambulated the Grass-market and Castle, and viewed the antiquities and pictures at the Institution and Gallery; and finally, at night from our hotel, admired the view presented by the old and terraced part of the city, lit up as it was with numerous lights, a sight which led us to think of society, manners, and events in bygone ages. All this, we fancy, is what we should have done, and what most do who visit Edinburgh.

Next morning our course was northwards; our destiration Aberdeen; our object, at least in part, the meeting of the British Association. We intended 
especially to have visited St. Andrew's, which must be a venerable and picturesque spot; though, judging from the accounts of it, science, trade, and religion wear there antiquated and threadbare garments. What havoc has been done in Scotland under the name of religion, at any rate to its religious buildings! Its capital bald from the destruction of its ancient temples, the cathedrals throughout the landdestroyed or in ruins, wide plains without one spire pointing heavenwards, or uplands with no warning bell booming orer them from ancient tower! The substance of religion, no doubt, remains ; covenanter meetings in the wild hills are romantic enough; massacres of these by prelates, or vice versî, are stirring enough; but, generally speaking, Scotch history and Scotch historiettes seem but a succession of cleeds of violence, covenanters and episcopalians, whigs and Jacobins, all bloodthirsty fanatics alike. Linlithgow seemed a sunny spot in the bright morning, yet its history, as well as that of St. Andrew's, illustrates the remarks just made. Bannockburn is the next noticeable spot; and here the English shone, being well beaten by the Scotch. 'Here, at Falkirk, the English were on one occasion the conquerors, but were again defeated by the Highlanders in 1746, who were in their turn afterwards subdued at Culloden. So is illustrated the saying, that they who take the sword shall perish with the sword; and hence arises the reflection, how happy now is the relation of the two countries to each other! We come to Stirling, famous for its castle, but which, like that of Edinburgh, must yield to Dumbarton in picturesqueness of site. The Bridge of Allan is a pretty spot, but we are quickly whirled on to Perth, with no more than a passing glimpse. In the distant western horizon several 
mountains appear, one of which was pointed out as Ben Lomond; but on this side of Scotland, generally speaking, there is no fine scenery. The roads to the Grampians or Scotch Alps branch off to the left at Perth and Cupar Angus, and we see only the outlines of the granite range, a spur attaining the eastern sea at Stonehaven. Perth and Scone, Glammis, Forfar, Montrose, and Laurencekirk are passed at railway speed. At Glammis we think of Shakspeare, or at least of his witches and Macbeth, and we might have done so earlier on our route, as we neared Birnam and Dunsinane. Approaching Aberdeen, the country presents many barren moors, and in many places rounded and grassy hillocks; and a discussion in the carriage arose respecting their origin, glacial or otherwise. No doubt our train was full of professors and learned men, converging to Aberdeen from the British Isles, as well as from the continent. Strange that the most learned always differ most. But to flit from hillocks of glacial drift or till to fish. Here on the seaside is Findon, whence the Scotch have their Finnan haddies, which we therefore asked for every morning at breakfast at Aberdeen, and which, followed by marmalade, added piquancy to the repast. One of the excursions of the Association was to Stonehaven and Dumnotar Castle on this coast, south of Aberdeen.

To most people these meetings prove truly agreeable and improving holidays. The Association is carried out on the most catholic principles ; every one has fair play. There is no aristocracy in science. Whatever is good and new in science obtains a hearing. Pretentious or charlatanic proceedings are commonly put down; not but that there are often old articles hashed up, such as have been once or 
twice before served at the Royal, Linnean, or Geological; and occasionally papers with a single corngrain amongst a great deal of chaff. There are also most terribly prolix papers and speeches, and others as dry; but altogether the reading of communications at the morning meetings, and the discussions thereon, are very enjoyable. Then there are also the evening lectures, commonly first-rate of their kind, and the soirées, including the exhibition of antiquities, geological specimens, works of art, \&c. At Aberdeen Sir R. Murchison held forth on the rocks of Scotland, fundamental gneiss, and so on, before a brilliant audience, in the new granite music-hall, then first opened. Sir Roderick rather hesitated to deal a blow at the catastrophe theory in geology, and was vers doubtful how far back we must date the first dawn of life. The Rev. Dr. Robinson followed with a discourse on electrical discharges in rarefied media; and illustrated his lecture by most beautiful and novel experiments, assisted therein by skilful hands. Then there were soirées, with exhibitions of historical portraits and antiquities of great interest, many of the latter appertaining to primeval man. But the event of the week was the Opening Address by that royal personage, now no more, but so much lamented; an address which showed that his intellectual powers and attainments were such as would have obtained for him a high position in science, had he not been otherwise exalted. In accepting the presidency he paid a compliment to science; the offer of it to him was another to himself, but one which he had real claims to, independently of his royal station. At this date (1859) the Darwinian theory was only just whispered; primeval man was scarcely yet roused from his slumbers; the geology of Scotland was but 
just taking a fresh start; so that, generally speaking, at this meeting there was no all-engrossing topic. Whilst the Association was in session, however, Captain $\mathrm{M}^{\circ} \mathrm{Clintock}$ returned with traces of the unfortunate Sir J. Franklin. Papers were also read on the geology of Aberdeenshire, on its drifts and submerged forests, on traces of the cretaceous formation in the county, on the parallel roads of Glenroy, and on the rocks and minerals of Breadalbane, by Nicol, Anderson, Harkness, and Rogers ; on the Flora of the district, on that of Braemar, and on the birds, zoophytes, and mollusca of the coast, by Dickie, Jamieson, Peach, Adams and others. I noticed in Aberdeen some beautiful pearls from the Don, Spey, and other rivers, shoals of fossil fish on slabs from Dura Den, and a collection of interesting animals from the Orkneys, one or two of which, amongst others a land-vole, seemed to differ from those of the mainland.

I had several rambles north and south of the city; southwards past the Lighthouses and the ruinous church of Nigg. The coast is here of granite rock, and rather wild, wave-worn into numerous caves, inlets, and islets. Northwards, the walk was along the links on a flat coast, till we come to Old Aberdeen and the Brig of Don. I picked up a few things both in the zoological and botanical way, but scarcely worth notice.* The valley of the Dee has been described in a work by $\mathbf{M}^{\circ} G$ Gillivray, published by royal command, and Dr. Skene searched this coast long ago. I saw a little of the venerable King's

* Glaux maritima, Salsola kali, Rumex maritimus, Lithospermum maritimum, Anchusa sempervirens, Ligusticum Scoticum, Cakile maritima, and Alchemilla alpina inhabit the shore or waste placcs around Aberdeen. Linnæa borealis, Goodyera repens, and Oxyria reniformis also occur in the neighbourhood. 
College, and of the neighbouring cathedral. Boethius was the first principal of the College, and was buried in the chapel, which is further remarkable for its carved wood. On the Brig of Don I gazed on the dark waters below, and then-turned back.

Professors and doctors abound in Scotland. The writer was dubbed professor in the landlady's bill. 'Ye are na a professor, then? Then may be ye are a doctor of medicine? No! ye are na a minister, sure?' I fell many degrees in the good woman's estimation when I affirmed that I was simply Mr. So-and-So. Iu Scotland, both speeches and sermons are quite long enough; some of the papers in the sections (as well indeed of Englishmen as of Scotch) were sufficiently prolix to test the listening powers of the Sphinx, if listening she be, or at any rate to have thrown her into her long quietus. For instance, Professor A- read a paper full of hard Greek words, confounding even the professors themselves, and of course still more ordinary mortals like ourselves, though we bought his book afterwards in vain hopes of some day mastering it. We do not, however, call in question the value of the essay. Then another professor spoke for two hours on molecules, with great ability, but it appeared to us that vast effort was taken to build up and demolish such little organisms; besides we were inclined to apply the argument cui bono in such cases. Then a venerable minister of Scotland, since deceased, eminent as a geologist, gave us a paper by a friend, of great length, ' on the passage of the children of Israel through the Red Sea,' and which threatened to exclude everything else announced for the same morning for the geological section. In vain it was endeavoured to stop the reader. Another professor, who had a paper on 
volcanoes to follow, was inwardly boiling like a volcano himself. One gentleman submitted to the chair that the paper was not geology. 'I'll come to the geology directly,' said the imperturbable reader. Another suggested that the reverend doctor had in mistake brought to-morrow's sermon, or that the Scotch proposed to keep Saturday as a Sabbath as well as Sunday, for that doubtless the paper contained no geology. ' It's all geology-dry geology,' was the answer to these and all other remarks, and so he finished his friend's paper, all to follow being as good as swamped. The next day to church of course, and enquiring from the landlady, 'I would go to hear Mister __ ?' ' Na, it inna the big lirk in Union Street; Mister ___ is a gospel minister-a powerfu' minister.' 'But I don't care about powerful ministers. I should hope, too, there is the gospel in most sermons, if we properly apply them.' 'Ah, weel, please your ain sel.' To the big church (St. Nicholas's) I went, but here I found two preachers and services, one at each end, east and west, I think. I hope they were not antipodes in other respects. However, there was no fault to be found with the preacher at our end; he had fears of the men of science of course, but upon the whole'was fair and liberal. All stood during prayer, and sate during the singing; no kneeling, I think. On one occasion I saw a respectable shopkeeper dragged from his counter, thrust into a vehicle, and hurried off to prison for the nonpayment of a church-rate. Does 'black prelacy' do more in England? thought I. But I dare say the man deserved what he got. In the Sabbath afternoon I, with some other philosophers, quietly walked to the granite quarries of Rubislaw, I hope not to the scandal of the Aberderonians. We simply used 
our eyes, and did not unpocket the hammer. The red granite contains fine crystals of schorl or tourmaline and of felspar. On another day there was a grand dislodgment of stone here by blasting, and experiments were inade on the subaqueous passage of electricity.

There were, during the meeting, or near its termination, excursions to Benachie, to the vitrified fort on the Tap of Noth, to Peterhead, Banff, and Elgin, and also to Inverness; but the expedition par excellence was to Balmoral upon the invitation of royalty. Of course many were anxious to see the valley of the Dee, the abode of our gracious Queen, the royal party itself, and to partake of the breakfast provided by Her Majesty's bounty. It was a long journey, and therefore it was necessary to take the train almost at daylight. We, too soon, got to the terminus of the rails, and then had to avail ourselves of such vehicles as offered themselves. The valley presents a succession of pleasing views-a small lake or two, the rapid river, groves of pine and birch, and, finally, rather bare granite mountains, and on the lower grounds forest; indeed beyond and around Balmoral is the country of the deer-stalker, and we are on the threshold of the wildest and the most secluded of the Scottish scenery-Cairngorm, Benmacdui, and Lochnagar; Braemar, Glen Tilt, and Blair Atholl; and further off to the west, Badenoch and Glenroy; and to the south, Schiehalien and Ben Lawers. Of these we can give no description to our readers, and for ourselres can but let loose the reins of our imagination-in fancy thread the fir forest, climb the rugged mountain, or journey along the lonely roads. On the morning of our journey to Balmoral we were promised a fine day by the meteorologists, but 
they proved quite out; the journey thither was one of constant and heary rain. My neighbour on the coach was Mr. P_, a gentleman from the far north, weather-beaten and weather-proof, but, though a teetotaller, warm-hearted, and, as he said, glad to make acquaintance with one of similar taste, a fellow mudlark; he was ever ready to while away the time by his Scotch songs. Down came the rain, and of course a canopy of umbrellas was spread out to cover us on the top of the coach; but at the same time that one of those useful articles covered the owner, it was liable to incommode his neighbour. ' My dear sir,' said one, turning behind, 'I wish you would hold the front edge of your umbrella up a little;' then another behind the offender, 'Halloa, sir, you are turning the rain into my lap;' the front man again, 'My good fellow, do please elevate the edge of this umbrella, the water drops down my neck.' ' Impossible, my good sir.' 'I tell you it does; I feel it running down my back.' The offender responds, 'Now hearken, sir; is not the umbrella the segment of a circle, and do I not incline its radius, the stick'just at this moment the axis of the carriage gave way, and we had to finish the journey on foot, which however, luckily, was nearly terminated at the time. A distinguished foreigner dropped his snuff-box, and for a short time thought it was gone for ever. In vain he was assured that he might get a first-rate Scotch snuff-box at Laurencekirk. 'Mon tabac! mon tabac! do none of you gentilhommes take de tabac? I am miserable! I am disconsolate!' The poor Abbé, who could calculate the tides or an eclipse, was in despair at the loss of a pinch of snuff, when a friend who had picked it up restored his box to him. His bow, with hand to heart, was most profound, his gra- 
titucle would be eternal, and his invitation to la belle France was most pressing. To Balmoral we got about mid-day, and the weather cleared up, so that we enjoyed the scene. The palace itself is beautiful, the valley sequestered, the surrounding mountains grand. The clans were gathered together for their annual trial of skill in their games, and their Highland costume, their banners and wild native music, added interest to the scene. They did the Highland dances in their best style, strange mixtures of the grotesque and graceful; quick moving feet and legs, angled elbows, and wild cries being essential parts of them. The Norse sword-dance, too, was admirably done. There were also trials of strength, such as throwing an enormous hammer or maul, and one or two other feats. No one could fail to admire Gaelic hardness, strength, and skill. Many were the miles that some of the men had come, mayhap from the sides of Don, or from other mountain glens, yet they left the valley in good style, banners flying, pibroch sounding, and caps waving. The successful competitors were summoned before Her Majesty, to receive prizes, suitable and substantial; though in some cases the mountaineers scarcely shone at presentation; their mistakes did but elicit the applause of the younger portion of the royal party. Different colours and tartans marked the several clans, and the caps of the chieftains were adorned with the eagle's feather. The various size, not to say age, of the men, and their free and undrilled step and carriage, did not decrease the effect as they left the ground.

Our gracious Queen seemed happy, and the Prince was by far the finest figure in the field, in full health, and set off by his Highland costume. There were all the young scions of the royal family too; and what 
could an Englishman better wish to behold? Breakfast was served us in the ball-room, and we were ready for it, philosophers of all sorts showing that they, least of all men, are insensible to their bodily wants. ' Waiter, a glass of champagne ;' 'Waiter, a cup of coffee,' was addressed to the attendants. 'Pardon, sir, we are not waiters ; we are the Queen's servants,' was the reply as the want was freely supplied. It was long after midnight when we got back to Aberdeen.

The excursion got up for Inverness facilitated access to the Highlands, and to the Caledonian Canal, by which route we will now suppose our readers landed on the west coast of Scotland, at that pretty little port Oban, whence is easy access to all that side of Scotland, and to its islands, sounds, friths, and lochs. Inverness, the capital of the Highlands, might claim particular notice, from its history, and from its remarkable site at the eastern opening of the Great Glen or Glen Albyn, here, however, less picturesque than at its south-western opening. Around the town, we have in the distance viewsto the south-west, of Mealfourvonie, and, to the north, of Ben Wyvis and of other hills, often capped with snow. The Falls of Foyers also are in the northern part of the glen, and for primeval antiquities this is a yielding field. But we are at Oban, on the Sound of Mull; the seas around it are beautiful when calm, especially in the long summer evenings. On June 26, 1866, at one quarter to eleven P.M., it was easy to read the smallest print of a newspaper when seated by the waterside. The hills which overhang the place scarcely rank as mountains, but are picturesque and airy, and within the capacity of almost any one to climb; and when on them, the views 
are fine and less wild than common in this part of the Scotch seas. Immediately opposite, and sheltering Oban, is the long island of Kerrera ; at no great distance, and towering over it and much further off, the island of Mull; to the right, far off, is that part of the mainland called Morven, looking dark and mountainous, its most distant point being the promontory of Ardnamurchan, both separated from Mull by the sound of the same name. On this side the sound, stretching into the Loch Linnhe and towards the entrance to the Great Glen, is the long island of Lismore; and the portion of the mainland on which we stand presents to our right, still nearer, the opening of Loch Etive. Of some of these more anon. Three or four miles inland from the town we came upon a small lake, Loch Nell. Lobelia Dortmanna, Littorella lacustris, and Myriophyllum alterniflorum grew here, as in most of the little lakes about; there were also several species of coleoptera (Dyticidce, \&c.) about and under the stones at its margin, and numerous small eels. Kerrera is easily reached by a ferry-boat; it has a castle (Gylan) at its southern extremity : it seems a pretty good spot for the botanist and ornithologist. A pair of oyster-catcher's were fiying about at the landing, and must have had their eggs or young near, as they were especially noisy; nest they have little or none. Ligusticum Scoticum (Lovage) and Vicia lathyrioides grow here. As at Oban, we have here the conglomerate of the Old Red, and also bedded igneous rock. At Oban, however, there is also some clay-slate, and I noticed the conglomerate, about two stones'-throw south of Dunolly, to be cut through with a very clean and neat perpendicular dyke of Green-stone (?) about a foot thick. There is a pleasant walk southwards from 
Oban under the sea-cliffs; but the water seems half choked with fucus and the Ectocarpus growing upon it. We presume they prevail so much here orving to the frequent calm, as we see them do, at least the latter species, in neglected and still tanks. The masses of conglomerate along the shore are very curious, its rounded component stones being many of them very large, and they will rather break than be knocked out. Above the cliffs on this side are found Hymenophyllum, Orobanche rubra, and a Pyrola. The north shore is a better hunting ground, there being roclis, sandy inlets, and little islets separated by shallow channels of the clearest water. One isolated cliff called Clach-a-choin, a little inland, I presume to be an ancient sea-worn cliff, but some of the pebbles seem as if cut or broken off. The curious nest of a wasp, oval and concentric, with the entrance below, was hanging from it, and I was near demolishing it by a blow from my hammer, in mistake for a pebble. Dunolly Castle on the cliff above is very picturesque, but presents little of interest upon a close inspection. On the moors behind, the yellow Iris, the fragrant Gymnadenia, the Marsh Orchis, and Aspidium oreopteris abounded. The Sweet Gale also grows everywhere in damp ground in Scotland, and, with the round-leaved mint and Artemisia, takes the place of Eau de Cologne or lavender-water with the Highland maiden. Dunstaffnage Castle is situated a few miles northwards, on the spit of land on the southern side of the entrance to Loch Etive. The celebrated stone of fortune, now in the coronation chair at Westminster, was once in this royal residence, and was at first removed to Scone. Near the castle, in the grove, is an ancient chapel, now used * Leottia nidus aris and Pinguicula Lusitanica also occur near Oban. 
as a burial-place. I also gathered Hypericum Androscemum, Vicia sylvatica, and Glawx maritima about Dunolly, as well as Hebenaria. Many lepidoptera abounded, as the burnet-moth, the green forester, the small copper Polyommatus Alexis, Melitoca Euphrosyne, Hipparchia Janira, H. Pamphilus, and the magpiemoth.

A ride of two or three hours, at the foot of wooded hills, stretching down to Loch Etive-- a salt-water loch, communicating with the sea by a rocky bar, over which at half-tide the water is said to rush with great force, and the upper part of which is extremely picturesque-brings us to Loch Awe, one of the largest Scottish fresh-water lakes. I noticed the Globeflower (Trollius), Rubus suberectus, and Polypodium phegopteris on this road, and many herons were fishing at the margin of Loch Etive. We followed up the rapid river Awe to the point where it is discharged from the lake. A lucky fisherman had here caught a salmon of large size. The river is given off from the lake in an odd way, rather at its elbow as it were, and it is believed that the lake formerly emptied itself from its south-west extremity into the Sound of Jura; for in this direction the glacier-striæ on its marginal rocks and islands rum; and it is probable that at that extremity it got dammed up, and then forced a way by its present outlet. This is grand, almost sublime; the steep rocks at the foot of Ben Cruachan shelving down sheer into the clear deep water, allowing room, however, on the north side for the coach-road, and for the lodgment of numerous detached blocks of granite, syenite, quartzite, and no doubt many other varieties of rock. My companions followed the land route, turning the beautiful head of the lake, and therefore seeing more of it, especially 
of the interesting castle of Kilchum, than I did, who traversed it from end to end in the little steamer. A fisherman got on board at one point with a famous batch of trout, in which I could distinguish three species; one appeared to be the lake-trout of Loch Awe (Salmo ferox), which attains a great size. The Salmonidæ, native of Scotland, besides the above species and the common trout and salmon, appear to be the S. eriox, or grey trout, often common as in the Tweed; the S. trutta, or salinon-trout, phinock whitling or herling; * the S. coecifer of Loch Leven; the S. alpinus, or charr of Scotland. To these may be added Coregonus murcenula, the vendace of Lochmaber; and C. Lacepedii, the powan or fresh-water herring of Loch Lomond; to which also may be subjoined the eperlang and the Hebridal smelt. Besides Kilchurn, there are several other ruins on the lake, quite close to one of which we passed. The colour of the water in these fresh-water lochs has not the beautiful green appearance which clear sea-water has. I noticed, at the head of the loch, Stellaria nemorum and Equisetum sylvaticum. There were, near here, many upright stones-I suppose memorial; in one place a group of them; also a ruined castle with a melancholy history. At one point on the loch a boat approached, rowed by two barelegged but otherwise well-dressed female Celts, and in taking in a box one of them fell over the boat, and, though her rosy limbs

* But Mr. Couch says that the phinock is a different species from the salmon-trout, as is the peal of the Solway and other waters; and that they all are distinct from the sewen of South Wales. Salmo ferox is found in Malham Tarn in England. The guiniad found in some of the Welsh lakes, as Llyn Cwellyn, and in Ulswater (schelly), is not properly attributed to Scotland. In England the rendace is found in Derwentwater. The common trout is subject to considorable rariations and monstrosities, as at Malham Tarn and Llyn Cwellyn. 
struggled manfully in the water, we, together with her frantic sister, feared she might go down; however, she was rescued, and she then immediately sat down, took up the oar, and struck out, without either a word, a cry, or a laugh. I fancy she (woman-like) principally thought how the ducking affected her appearance.

Another journey, or rather royage, was to Glenco, Fort William, and the western entrance to the Caledonian Canal, at the foot of Ben Nevis, where the mountain rises in stern grandeur, as if monarch of the Great Glen. We passed Lismore Lighthouse to the left, and Lochs Etive and Creran to the right, and were then in Limnhe Loch; passed Appin, a castle situated on a solitary rock, and one or two others. A raised beach is to be traced all along this coast at one uniform height. In the loch were shoals of Medusæ in active exertion, well seen in the clear and perfectly still water. At Ballahulish we left the steamer, and proceeded past some slate quarries, situated on the shore of Loch Leven, to Glenco. The rocks on the roadside appeared both moutonnés and striated; the slate seems deteriorated by the iron pyrites which it contains in square crystals. We dared not stay to look for traces of organic remains, lest we should be left behind. On by coach: the mountains to the south had their summits wreathed with snow. Glenco is a desolate hollow, with but one inhabited house, but having traces of othersa few clumps of trees, a few walls, and so on-the former residences of the massacred natives, whose sad tale is so well known. The time allowed us was short to look around in, but in the lake was plenty of Lobelia, Myriophyllum, Chara, Littorella, and Subularia; and on the roadside, Alchemilla alpina, Saxi- 
fraga aizoides, and Oxyria reniformis.* The Fontinalis moss, in a rivulet which fed the lake, was covered with a gelatinous mass, either an alga or compound desmid; $\dagger$ and the lake also abounded with little shells, Gulnaria lacustris of Leach, and Amplipeplea involuta, no doubt the principal food of the trout and other fish. Boulders of felspar rock, and variouslycoloured porphyries, lay by the roadside. The summit of the pass looks down towards Bannock, Breadalbane, and the central forest district, the haunt of the wild deer. The little river flowing from the lake towards Loch Leven is the Conan of Ossian, and a cavern far up on the south side of the glen has been named after him.

We took boat again, and entered Loch Eil, touching at one or two places at the mouth of the canal, at Fort William, and then at Corpach. Here a couple of hours were allowed - time enough to make a détour on the hills to the left, or to take a conveyance and ascend the glen at the foot of Ben Nevis. I preferred the former, and I got a fine view of the shattered and dusky summit of the mountain; also picking a few plants-Galium boreale, the Dwarf Juniper, Drosera Anglica, and Habenaria albida. In front of a cottage grew plants of Inula helenium and of Angelica, no doubt the simples of the Celtic pharmacopœia. Of the latter I enquired the name of the dame. She could not speak English, but called it 'mulcham,' as far as my ear could distinguish the sound. The

* Dryas octopetala, Rhodiola rosea, Saxifraga stellaris, Hypericum androsæmum, Hieracium alpinum, and Hydipnois taraxaci are also found here. Near Loch Creran, mentioned above, is the habitat for Oxytropis Uralensis:

$\dagger$ The stream also afforded a clear gathering of duatomes, Epithemiæ, Gomphomena geminatum, Cymbella Helretica and gastroides, and Campylodiscus Hibernicus. 
status of the Highland poor seems bad, yet without the squalid wretchedness so common in England and the larger Scotch towns, as Glasgow, no doubt often brought on by drunkenness and improvidence. Where is such poverty as in our islands, and yet where such riches? Both seem to increase in corresponding ratio in the two classes. Mean are the onestoried cottages of the Highlanders, yet they are cleanly whitewashed without and neatly thatched; they are but too often destitute of gardens, and have a midden in front in lieu of the pretty little enclosures which we often see before English cottages. The diet appears to consist principally of oatmeal, potatoes, and poor fish, such as podleys. Many of the islands bave miserably decreased in populationanother sign of the times. Few vegetables, and little grain, except bear-barley for wlisky distillation, and oats, can be grown, and these not always. The Highlanders, however, are not behind the English in education, to say the least, but the intellectual - the enterprising-portion of the Scotch are often, perhaps, a mixed race, not real Highlanders, who themselves, to the west, are commonly of Celtic blood; and to the north, probably Norse. In the chapel at Oban, filled principally by natives, the males were personable enough, but certainly there were few beantiful women in the congregation. The singing, led by the precentor in a kind of recitative, was wild and characteristic, not loud, but subdued; one scarcely knew the old psalm-tunes, so treated. Our journey back to Oban was by the same route.

The trip to Iona and Staffa takes a long day. We passed the southern extremity of Kerrera and its castle, skirted on our starboard side the desolate southern shore of Mull, a long reach, scarcely a trace 
of a house or human being to be seen on the shore all the way; at the bottom of one little bay, however, there did appear a white cottage; far to the left were Colonsay and Oronsay. The coast, curiously enough, presents traces of oolitic formation, with igneous rocks; in fact, some beds of nolitic coal. At Corsaig the porphyritic rocks become basaltic, and rise in aggregated columns, sometimes worn into arches by the sea and other agents. At the extremity of the island granite or syenite is the formation; to the north of this promontory is Ardtun Head, where curious tertiary leaf beds occur, as described by the Duke of Argyle. But now we are in an archipelago of islets, some green with vegetation, others of naked red granite, excepting a hoary covering of grey lichens upon their crests. There was a great shriek from the sea-birds ; the little guillemots looked pretty in their clean black and white plumage; and there were barnacle- and eider-ducks and sheldrakes; the gannets, too, were seen to fall perpendicularly into the water like stones, after their prey.

But what is that sad-looking shore, at a little distance slanting up from the water into the higher grounds, and with a solitary tower and building upon it? Doubtless the holy isle, Iona or Icolmkill, divided by a little strait of ocean from Mull. As we approach, we see a long row of the cottages so characteristic of the isles; they contain a miserable population. One regrets that in such a kingdom as ours no means can be devised of raising the condition of these poor Celts, for Celts they are, and, unlike the men of Orkney and Șhetland, speak the language, and often no other. The islet is of the fundamental gneiss, as it is called, but there are huge boulders of red granite or syenite at the landing-place, and a good portion of the 
cathedral is built of syenite and mica schist. There is also in Iona a kind of marble, formerly worked, bearing its name. The facings, pillars, and carvings of the cathedral appear to be of freestone. The natives earn a penny by selling sea-weeds, and especially rounded pebbles of nephrite, to the visitors. There is a fine white shell-sand driven into the little bays of the shore. We landed in boats. How beautifully clear is the sea when there is nothing extraneous to sully its purity! We first visited the Nunnery, the style being Norman, and therefore the building is of no mean antiquity. There is the tomb of the last prioress, Domina Anna, and another of a daughter of John Lauchlan. Maclean's cross is of slate, and of curious sculpture; on one side the crucifixion is represented. Reilig Oran is a burial enclosure, having St. Oran's chapel within it, a building also of considerable antiquity, where, according to tradition, St. Oran, the companion of St. Columba, is buried; there are also the tombs of a M'Quarrie of Ulva, and of a $\mathrm{M} \cdot$ Donald of the isles. Amongst other carvings is the ancient emblem of Mona, a ship with sails unfurled. Many Irish and Scotch kings, a French one, and lairds and bishops without number, are also said to rest here. Before the Cathedral stands St. Martin's cross, also of beautiful sculpture, the centre on one side representing the Virgin and Child. There is nothing in the Cathedral itself which in any other situation would be considered supereminent; though the hands of masters in architecture raised it, for there is much grace and beauty in the building, and some rather elaborate work. Neither does it present us with any traces of St. Columba or of the Culdees; for, commonly speaking, it is subsequent in date to even the early pointed architecture. St. Columba is supposed to 
have landed in his wicker boat or coracle at Port-aChurraick, in 563. At the western side of the island is a place called Carn Cuildich, with vestiges of buildings. The Cathedral is a cruciform building; the east window is decorated, as is the tracery in the steeple lights; the flying buttresses, the pillars and the capitals, the doorways and their mouldings, and the sedilia and piscina, are all interesting. In the chancel are the tombs of Abbot Mackimon, 1500, and of the abbot Kenneth Mackenzie; between the two is a large slab, covering the remains of a Macleod; the brass has been removed from the intaglio figure. A greenish caterpillar was feeding on the Bedstraw growing about the ruins; it afterwards turned to the Pohlia chi. The Hemlock was common enough in the deserted enclosures, and, it is said, the Belladonna; howerer, I saw neither that nor Cotyledon here, though one would suppose that the latter at any rate would occur.* And now, in returning to the boats, I sounded a clerical acquaintance from England, that I had met on board, in fact a prebend of one of our cathedrals- 'Should such a place be restored?' He looked at me with astonishment at my seeming to doubt its advisableness. 'Many,' said he, "would be the clergy who without any monkery would be glad to retire there-it may be for life, at any rate temporarily.'

Seven or eight miles north-north-east from Ioua, in the open sea, is the rock-isle of Staffa ; in the distance,

* At some seasons the walls of the ehancel and its tombs are purple with a Trentepohlia, mentioned by Lightfoot, under the name of Byssus purpurea, as growing there. Thalictrum minus, Rhodiola rosen, Cakile maritima, Ligusticum Scoticum, Lithospermum maritimum, Salix Lapponum, Scilla verna, and Pinguicula Lusitanica are Iona plants. On some parts of Mull, opposite Iona, Arbutus uva ursi corers the surfaco. 
far in the north-west, are Tiree and Coll; also on the same side the curious islands of Treshinish; one, from its shape, called the Dutchman's Cap, and another with a curious natural arch. Geometray lies between Staffa and Mull. The sight of Staffa produces wonderful interest, such is its grandeur and solitude; probably the view of it from the sea is the most effective. It may perhaps be said to consist of, at the base, amorphous igneous or volcanic rock; then come the basaltic pillars, varying in length at different points, also in their size and geometry, but upon the whole wonderfully regular; and above, another bed of amorphous or somewhat contorted or stratified rock of similar kind, covered with the soil and turf. The day was fine, and after steaming past the caverns we easily landed (one of the boats being leaky, however), and walked along the island a halfmile or so, back to Fingal's Cave, where we descended from the high turfy level on to the tops of the basaltic pillars, for rows of them had been cut down, as it were, by the waves, and on their tops was a good road into the cavern, somewhat awkward, however, just at the entrance. This cavern has often been described by better historians than ourselves. There are no inhabitants on the island, but rough sheep, rabbits, seals, and otters, with numerous birds. I noticed two small stone eircles, but the large stones had disappeared, probably weathered into the rounds of smaller ones, which I saw. Had they been druidical circles or ancient dwellings? I picked a few plants, Pyrethrum maritimum, Asplenium marinum, Gymnadenia conopsea, and a few Carices and Junci. Orobanche rubra also grows here. Near the landing the columns are very imposing, as they are in other places on the island besides Fingal's Cavern; nor is that the only 
cavern. The steamer ought, if possible, to circumnavigate Staffa, to give one a good idea of it. We now made the north of Mull, and entered its Sound between the island and Morven. The steamer was on a pleasure trip from Inverness, so we did not touch at Tobermory, but simply showed our comely proportions by turning round in the bay, our kilted Inverness band playing a Scotch song, 'Auld lang Syne,' I believe. There is here a waterfall, which tumbles into the sea, and in the distance is Ben More, the lighest mountain in Mull. We passed castles Aros, Ardtornish, and Duart, and the Lighthouse at the point of Lismore, and so back to Oban. The Scotch ruins commonly are not large or fine enough to riva] Conway or Carnarvon.

'That steamer is for Stornaway in Lewis,' said my friend; 'don't you go?' 'No; if I were there I should long to go to the Orkneys, and if at the last, Shetland or St. Kilda would be the Ultima Thule of desire.' 'Well, you'll go to Skye, won't you?' 'Indeed no; you go, my good friend, and then tell me what you have seen; and mind you bring me all the plants you can find, and especially the Eriocaulon.' - ' Well, a, pretty voyage you sent me; a miserable and dreary island, at least to me, who have no taste like you for wild moor, barren rock, and treacherous bog. Besides, it turned out to be the half-yearly fast, and though perhaps the people of the island did not really fast hard, yet they seemed to look upon me as a heathen for thinking of anything but of going to hear the great gun from Edinburgh, who was preaching at Portree. The islanders themselves assembled from all the corners of Skye to hear him, notwithstanding a wet day, listening to him in the open air under umbrellas, and the service occasionally varying with 
Gaelic hymus.' 'And the voyage?'-'Well, you steam out of the Sound of Mull, round Ardnamurchan promontory, and see on the larboard side the Island of Eigg, with its basaltic scuir, such as it is described by Miller, and more recently by Geikie. You pass the openings of several lochs, also Arasaig, and so into the Sound of Sleat, between Skye and the mainland. Knock Castle is seen on the Skye shore; Kyle Phea, and Kyle Akin with its castle (Moil) and lighthouse, have next to be threaded before you again get into a more open channel, and so into Broadford Bay, at the entrance to which is the Island of Pabba, described by Miller as consisting of liassic strata. It was a hard day's work to do the Cuchullins from Broadford, and that too with proper appliances. A journey of a few miles leads to Torrin, on the other side of the island on Loch Slapin. The next inlet, Loch Scavaig, has to be attained, and thereto the intervening promontory has to be crossed, or (more easily) rounded in a boat, when we see some caverns, produced by the unequal wearing away of the strata of the coast; one called the Spar Cave, a very interesting place, and another associated with the Pretender, as many other spots on these coasts are. At the termination or head of the last-named loch or bay a river enters, running from Loch Corruisk, itself surrounded by the Cuchullins in all their grandeur of peak and corry. Their structure being of hypersthene rock, peculiarly influences their weathering, and the evidences of glacial action which are to be seen around render them interesting to the geologist. In fact, these mountains are amongst the most sterile, savage, and picturesque in the land, and the loch is solemn and desolate enough even for thee, my friend! We regained the boat for Camasunary, and 
the walk thence to Sligachan Inn is through an extremely wild and rough valley, with high mountains at the sides, and one or two little lakes and a stream at the bottom, the path being mostly over broken rock, or through bog and streams. The mountains on the left hand were the Cuchullins, as said before, of hypersthene rock; those to the right, on the contrary, were granitic or syenitic, dome-shaped, and less striking than the shattered Cuchullins. From Sligachan it was easy to make Portree, and hence the cliff scenery to the north may be visited-Prince Charles's Cave and the Storr rocks-by means of boat, with no great difficulty. The Quiraing and the basaltic Staffin shore is further on, facing the more open sea towards the Minch. The very remarkable pinnacled or tabular rocks just mentioned, the Storr and Quiraing, are all the result of the unequal waste of igneous rocks, resting upon an oolitic basis. A "Summer in Skye" will give you a very interesting and lively account of every-day life in the islands and of its history-the Norse; the lives and feuds of the Macleods and Macdonalds; their castles or duns, Dunvegan, Duntulm; the Pretender and Flora Macdonald; Dr. Johnson and Boswell. The islanders are generally rather a small and poor race, partly, no doubt, from intermarriage, partly from their miserable habitations, constructed sometimes of turf, or rough stones and mud, and with little light, and also from poor nourishment. Idiocy seems too frequent for the number of the population. Soon may the iron road penetrate as far as possible into these northern wilds, and may the wealth of richer districts be scattered here in return for what is better than wealth, health and pleasure - exhilarating mountains and enchanting lochs!' My friend produced a few plants - Alchemilla alpina, Saxifraga aizoides, 
Parnassia palustris, with some Junci and Carices, but missed the Eriocaulon.

But, farewell, Oban! farewell, Kerrera ! farewell to the western lochs and mountains and seas! It was a beautiful calm morning when I took the boat to Glasgow, leaving my friends behind me, they having more leisure than myself. We pursued our course amidst an archipelago of islands, stopping first at Easdale, whose slate quarries glistened curiously in the morning sun. On one island is a lighthouse, and they are generally pretty objects. The coast is very sinuous and complicated. There are several castles, but none of them very striking objects. We stopped at Crinan, at the entrance to the Sound of Jura, and passed across the peninsula of Cantyre to Ardrishaig. One gentleman offended a Caledonian much by enquiring how long that ditch (the canal) had been cut. The stoppages of the little steamer at the locks gave opportunities to the pedestrian. The ground abounded in rounded and worn boulders of many sorts, and there appeared in one place to be a remarkable fault affecting the surface in a line of cliffs, besides numerous dykes. We again took a larger steamer, traversed Loch Fyne, touching at Tarbert and one or two other places, doubled the promontory of Ardlamont, and so entered the narrow and picturesque Kyles of Bute, leaving the fine Isle of Arran seawards to the right, capped with clouds on this occasion. Mr. Landsborough's account of that island will give much pleasure in the perusal. The Kyles, though shortening the voyage to Glasgow, are, after all, a very crooked passage, but their beauty makes amends, particularly at the nurthern point or elbow, whence their course becomes south-east at an angle with the channel from the south-west. Here was 
Burnt Island, interesting to the archæologist, and Ellandheirig Castle or Red Island; then came Rothesay in a fine bay, and we were in the Clyde Firth; and so on to Dunoon, Greenock, the rocks of Dumbarton, and finally Glasgow. I had stuck to the steamer to the last, at the expense of my olfactory organs. What would the sensitive habitants of the Thames banks say to Clyde's abominations? If we can imagine a putrid ink, we have Clyde water.

Glasgow is surrounded by coal and ironworks, but the Cathedral (restored at the expense of Government) and neighbouring Cemetery are picturesque, and the city itself well built. I slept two nights here. The first day I got up at a moderate hour for rising, and breakfasted well on board the steamer on Loch Lomond, the pleasant summer breeze blowing through the saloon, and being regaled with trout, herrings from Loch Fyne, and sweets of course. How pleasant for the Glasgovians to do this ; nay, more, to make the détour of the lake, ascend Ben Lomond, and get home to dinner! Or they may do the Trosachs and Loch Katrine, in addition to Loch Lomond, in a long summer day. The pretty black-headed gulls closely follow the steamer on the lake, as the herring gulls did in the Kyles of Bute, in the hope of a bonne-bouche. I landed at Rowardennan at the foot of Ben Lomond. Some young ladies beat me terribly at climbing, making me to feel that my motto hereafter must not be Excelsior. I came upon a deer in the bushes, which quickly got into the thick covert. Rosa villosa adorned the margin of the lake with a profusion of its blushing flowers, and there were some large brown-red ants, which had erected enormous mounds with fragments of fir leaves and its flowers. I finally had to retreat from them. 
Some present voids in the Fauna of Scotland may be attributed to the agency of man, some perhaps to an amelioration of climate. To the former may be ascribed the disappearance of the bear, existing in mediæval times. The remains of the beaver are found under the peat, and it also seems to have continued to the same period. The capercaillie, if it ever were a native, has disappeared as a truly wild animal, and the great auk appears to be all but extinct. To change of climate may perhaps be attributed the disappearance of the walrus and great seal, whose remains have been found in recent deposits. The Alpine hare, the snow-fiake, and the ptarmigan still continue on the high moors; the lastnamed is now unknown in Cumberland, where it formerly existed. The mugg is the native sheep of the Highlands, small and horned or not, but the face white or spotted with yellow, and having the forehead covered with long wool. The Shetland variety has fine wool next the skin, together with long coarse hairs; they are not shorn, but the wool is plucked off by rowing; of this wool the beautiful shetland fabrics are made. The land- or golden, and the sea- or white-tailed eagle are far from extinct, and the osprey builds in many places, as on Kilchurn Castle, on Loch Awe. The shoveller, merganser, and blackthroated diver frequent the fresh-water lochs. The skur and the Arctic skua breed in Shetland especially, where they are protected as guards against the eagles.* Scotland has not the nightingale nor the black-cap; the little crested tit is found about

* The eggrs may be obtained at Lerwick; the price of one of the large skna is eighteenpence; of the Arctic species, one-third the cost. The eggs of the fulmar, red-throated diver, stormy petrel, and raven are also to be had. 
Glasgow. Dr. Fleming gives a good account of instances where remains of animals at present extinct in Scotland, but of the human period, have been found. In the Museum of the Andersonian Institution we saw some remains of this kind, and others of animals not extinct, but found where, in the present state of the surface, they could not be deposited. There are the cranial fragments of a whale (Balcenoptera boops) found near Stirling, twenty feet above the sea-level, and two miles from the Forth; remains of the whale have also been found at other places near that river, but higher than the present banks; and a vertebra of a Cetacean at Strathpeffer, under similar circumstances; so with remains of the Bos primigenius, of the reindeer, and seal. In the Museum, too, is one of the boats found near the Clyde on the site of Glasgow; also shells of recent character, but some of them rare or even extinct in our now warmer seas, obtained from the ancient sea-beaches by Mr. Smith and Dr. Scouler.

Wheat cannot be grown in many parts of Scotland, in the west there are few localities suitable for it, and it appears to be seldom sown in North Britain at a higher altitude than 800 feet. Further north, as in Orkney and Shetland, even oats and barley do not always ripen, but such is sometimes the case even in the moorland parts of England at high elevations. In fact, in West Scouland, the vicinity of the sea seems, upon the whole, to make amends somewhat for the high latitude-increasing the altitude where plants cease to be found, and raising the mean temperature. The ling ceases on the north side of Ben Nevis at 2,100 feet; Empetrum nigrum grows several hundred feet higher. Of course, as we go southwards, this line of cessation becomes 
much more elevated, as will appear in the chapter following.* A great number of plants that are found in England, and even common there, are rare or absent in Scotland, at least in the northern part. Scotland wants many of our aquatics, but, on the other hand, has some lake plants which are rare or absent with us, as the Eriocaulon of the Skye lakes. Of Scotland's more Alpine plants, which are the pride of her Flora, and which are peculiar to her, as far as Great Britain is concerned, some are quite of a boreal origin, others are more simply Alpine, and therefore occur in the Alps of central Europe, whilst two or three appear to belong to the Lusitanian family. A considerable number of plants not found anywhere else in England or Wales are enumerated in our notes below according to their localities. On the mountains, as in northern England, are found, commonly enough, certain maritime plants, often at a great elevation; for instance, Silene maritima, Statice armeria, Plantago maritima, and Cochlearia, on Ben Neris, \&c. On Ben Lomond are the Alpine plants given in the footnote, $\dagger$ and Ben Cruachan shares with it, and with Ben Nevis, Azalea procumbens. Ben Cruachan has also beneath its shadow, at the head of Loch Awe, the interesting variety or true species of Nuphar, N. pumila. Nevis has many truly Alpine species, $\ddagger$

* Certain mosses are perhaps more peculiar to and characteristic of high $A$ lpine situations than lichens. Andrea alpina and $\Lambda$. niralis occur on Ben Neris; Splachnum tenue on Ben Lawers. S. vasculare, S. Frælichianum, Cyrtodon splachnoides, and Conostomum boreale are also rare Scottish Alpine species.

$\uparrow$ Cherleria scdoides, Sibbaldia procumbens, Gnaphalium supinum, Veronica alpina.

‡ Sibbaldia, Cerastium trigynum, Veronica alpina, Ajuga pyramidalis, Salix lapponum, Juncus trifidus. 
some of them of the boreal type,* and Ben Lawers has others ; thus each mountain owns some peculiar to itself. East Scotland (as Forfarshire and Clova) has some varieties of Flora exclusively, that is, as far as Scotland goes, $\ddagger$ and so of other parts of the countrys and of the extreme north.\| Some of the east coast plants may have their true home in Eastern Europe.

The sounds, kyles, and lochs of western Scotland have afforded rich harvests to the zoologist; and, to go no further than Oban and Lismore, many of our greatest rarities have there been brought up by the dredge, or occasionally thrown up by the waves: for instance, Terebratula caput serpentis and Crania anomala, almost our sole British representatives of numerous extinct forms. Terebratula seminalis has been obtained on the coast of Skye, and that pretty but minute mollusc Spirialis Flemingia. If robbed of the products of the Hebrides, Orkneys, and Shetlands, very much of the interest pertaining to our marine zoology would be lost. For instance, among the Radiata occur the Euryale (Asterophyton scutatum) in the northern islands; not a boreal species, however, for a friend gave me a specimen which he fished up at Gibraltar, close to the station of the

* Saxifraga cæspitosa, S. rivularis, Arctostaphylos alpina, Alopecurus alpinas.

† Gentiana nivalis, Veronica saxatilis, Salix reticulata, Juncus castaneus and Draba hirta, Saxifraga cernua, Erigeron alpinum, northern or boreal as well as Alpine forms.

$\ddagger$ Lychnis alpina, Eriophorum alpinum, Astragalus alpinus, Oxytropis campestris, Sonchus alpinus.

$\S$ Salix lanata, Pyrola uniflora, Salix myrsinites and reticulata, Polypodium alpestre, Cystopteris montana, Alpine plants; Corallorhiza innata and Goodyera repens, scarcely so; Luzula arcuata, and Menziezia cærulea, northern and Alpine.

\| Hierochloe boreale, Pinguiculas alpina. 
convict ship, named (curiously enough) the Euryale. The spiny cross-fish occurs in the Skye channels, and the little cross-fish has been taken at Arasaig. The piper (Cidaris) and the cake-urchin are rare Shetland species; the purple egg-urchin occurs at Arran as a burrower, and the fiddle heart-urchin is found in Rothesay Bay and in the kyles of Bute. Among the zoophytes occur the interesting Pennatula phosphorea or sea-pen, the Virgularia mirabilis found near Oban by Mr. M‘Andrew, and called in Shetland the sea-rush, and Pavonaria quadrangularis, found by the same gentleman and in the same place; this last appears to be a representative of certain ancient fossil zoophytes-' it lives erect, its lower extremity, as it were, rooted in slimy mud, at a depth of from twrelve to fifteen fathoms. The largest specimen taken was forty-eight inches in length.' Gorgonia pinnata inhabits the Sound of Skye. A new species of Pennatula, and also Tethea cranium, have lately been dredged in the Minch by Mr. Jeffreys. Sereral of the Arctic species of mollusca brought up are rather fossil than recent. Sepia officinalis does not seem common in Scotland, nor has, I think, Onchidium Celticum been found. Fusus antiquns is used by the Shetlanders as a lamp. Pinna pectinata is found in the Hebridean seas; nor are the Arce absent. Captain Carmichael investigated the marine microphytology around Appin.

The following molluses are met with at Oban:Cyprina Islandica, found by myself; several rare scallops, Lima hians and subcuriculata, Leda caudata, Isocardia cor, Syndesmya intermedia and prismatica, Lyonsia Norvegica, Pandora obtusa, and Necera cuspidata, bivalves; amongst the univalves and gasteropods, Chiton Hanleyi and cancellatus, Pilidium fulvum, 
Emarginula crassa, Trochus unclulatus and pusillus, Trichopteris borealis, Trophon Barvicensis and clathratus, and many others.

- On two evenings I got admission to the Andersonian and University Museums at Glasgow; at such places one very often meets with old friends-I mean things which we have read about. Several such objects are contained in the first-named collection, and have already been alluded to. There is also a collection of shells from the drifts, old sea-beaches, and similar deposits, the different mammalian remains, and rude works of man which are found with them in some cases. The coal-plant Stigmaria is illustrated by the trunk (Sigillaria) and a root of great length. There is a remarkable Rhizodus, or rather a Rhomboptychius, I believe, and also jaws of reptilian fishes from the coal strata; likewise specimens of rare recent fishes caught on the western coast of Scotland, and which have mostly been brought into Glasgow market, as the bonito, tunny, opah, sun-fish, blue shark, and others. A valuable collection of the lower animals was made by Dr. Scouler, and they are here preserved, many of them in spirits-annelides, molluscs, radiata, and so on. The University or Hunterian Collection is of known celebrity, sadly crowded, however. The coins are almost unrivalled; the pictures extremely interesting, many of them especially to the members of the medical profession; the anatomical preparations, too, are amongst the most interesting of the kind, and well described in a cheap catalogue; the fossils, especially the carboniferous, and the minerals, and, lastly, the archæological contents of the museum, are also valuable and interesting. The curator has formed an unrivalled collection of the rarer and more minute fossil forms of the carboniferous rocks. 
Few countries probably present finer opporitunities of investigating what may be called the higher geology than Scotland. Recently Mr. Geikie has published an interesting book, principally treating of the formation of the mountain and valley systems of the country. He ignores, for the most part, all violent elevations and depressions, all cataclysms, in fact all so-called convulsions of nature-all that is different to what we see taking place before our eyes at the present day. The high lands have been elevated gradually, and only as a table-land; the mountains themselves have been shaped by the action of the air, of rain, springs, and rivers, and of frosts, acting through the countless ages of the past. Valleys and lakes owe their origin to the same agents, aided, it may be, by the grinding of former glaciers, the mechanical action of ice-floes, or the wearing away by the sea in some cases. The amount of denudation has been enormous. Denudation from various agents, as just enumerated, not the elevation or protrusion of rocks and mountains, formed the valleys. Thus it has been the action of wasting agents rather than of volcanic or subterranean force which has done all which we see. Traces of the grinding of glaciers are evident in every mountain valley. The sea, too, when the land has been submerged, has levelled it by its own action, ploughed it by its currents, and dropped upon it from icebergs beds of clay and sand, with gravel and boulders, in many cases obliterating all the traces of farlts, and of elevations and depressions from previous igneous action. He gives instances where the tops of mountains are far from being formed by anticlinal elevation, but where the stratification is the reverse; and so, vice versâ, with the valleys and loch-basins. Nerertheless we think subterranean force and stratification are too much 
ignored by Mr. Geikie and his school, as far as regards the configuration of the surface, and this even in the Highlands, and according to his own showing. In less mountainous countries than Scotland, too, it may be seen, that though faults of vast extent and depth are more or less obliterated as far as the surface is concerned, and though the summits of hills are not always on the same line as, and formed by the cropping out of, the stiata, yet that dislocation and stratification in some cases considerably modify the surface of the country. Again, thongh the reasoning of this school often seems triumphant, jet it leaves much to be explained, and takes little note of the successive epochs and formations of geologr - the secondary and tertiary ones, for instance, of which Scotland presents us with traces in the aistricts treated of by Mr. Geikie. Vast ages of geological time, and vast series of phenomena are all but ignored.

The formation of hills and rocks of so-called igneous origin, as of Edinburgh Castle and of Arthur's Seat, for instance, is not admitted to have taken place by an elevation into the open air, but it is maintained that in all such cases the formation has taken place between or with the other strata, and that such ioneous deposits, as a harder material, have been left when denudation has swept away the softer beds. Mr. Geikie's account of the Scuir of Figg is interesting; that extraordinary basaltic pile has not been injected into daylight, as we see it now, but was at first a mass of fluid basalt flowing over a river-bed, and consequently strata far higher than its now towering columns have been swept away, and left their summit, a weird wreck of ages long gone by, 1,335 feet above sea-lerel. 


\section{CHAPTER VII.}

\section{ABROAD.}

How different are his feelings, when the young man first leaves his native shore for a strange land, to these which he experiences, when twice as many years have been added to his life, and he again ventures-ventures now to cross the sometimes disagreeable and treacherous waves, and place his foot on a foreign strand! On June 1, 1830-a memorable year for France, and on this account, perhaps, my recollections may be worth recording-myself and a fellow student embarked in the Calais steamer at the Tower stairs. It was early morning, and pleasantly the beautiful day passed. Woolwich, Erith, Gravesend, Sheerness, North Foreland, and Margate were passed, and faded away, and the evening saw us landed at Calais. The women's white caps, the boat-loads of splendid mackerel not long caught, the eager caterers for the hotels, the chimes of the Hôtel de Ville, the dreary-looking ramparts and bastions, the gate figured by Hogarth, leading from the sca into the town, and the surveillance of the custom-house and passport officers (the latter now done away with for Englishmen), were the notabilia which then struck the regard. Then came a journey of two days to get to Paris. Steme could make stich a journey sentimental; ordinary mortals cannot. Yet the route ought not to be uninteresting to an enquiring 
Englishman. We were occasionally requested to walk, perhaps through a village foreign-looking enough, or through a forest-such as forests are in France, grand rather from their vastness than from their great trees. Then there was the ponderous diligence, and its small but powerful and rather ricious horses, with their rope traces, and the important conductor; and liere it would go jog-trot along a far-stretched and straight road, the wide and green sides of which were planted with rows of trees, and the middle, perhaps, paved with great stones like some of the Cheshire roads. Going, we passed St. Omer's, Amiens, and Chantilly; returning, Beauvais, Abbeville, Montreuil, and Boulogne. Agincourt lies on the first road, Cressy on the latter, and surely Englishmen should visit these spots. C'æsar embarked for Britain somewhere between Calais and Boulogne; perhaps liis present distinguished biographer will be able to tell us the exact spot, being so well acquainted with the coast. Abbeville was said in our school-books to be famous for begrars; and indeed, in passing through it, the traveller was sorely pestered by their solicitations; but probably things are better now; indeed, the above towns are now the delectanda of architectural tourists for their beautiful ecclesiastical building's. French churches have often their arched portals very rich in their details, their mouldings elaborately sculptured with canopied figures, even throngh the bends of the arch; often with apsidal east ends, and side chapels between the buttresses; the latter dedicated to particular saints, and each having its legends connected with it, and being the resort of such saint's particular votaries. Besides their rich fronts, many, at least in Normandy, are remarkable for their circular windows, 
called vulgarly rose or Catlierine windows, often filled with beautiful painted glass. The front of the church of Abbeville was commenced under Cardinal d'Amboise, the benefictor of Rouen cathedral. The nave of Amiens cathedral is of great height, and the architect of Beauvais is said to have been ambitious to surpass it in loftiness, but lost credit therein. It looks strange in the distance. It is but the portion of a church; its height is 153 feet; it is strengthened by remarkable buttresses and rows of pinnacles.

Boulogne had not in those days the scientific attractions it has now; and the flints of Abbeville, Amiens, and St. Acheul were not dreamt of. Both geologists and divines often quoted Cuvier's opinion as to the comparatively recent date of man's appearance upon the earth, and that his remains had never been found contemporaneous with those of any extinct animal. At the cathedral of Amiens is the head of John the Baptist. Other heads of the saint there are, but Dr. Manning, we see, explains matters satisfactorily, at least to himself. He says portions of the head are at other places, and that Amiens possesses only the front part. At the entrance are two effigies in brass; that to the left, of the founder; and that to the right, of Bishop Geoffroi d'Eu, 'learned in physic as well as in theology.'

It is original to commence one's travels with both the setting-out and the return, but the thread of our discourse may be less flimsy when so doubled. In those days English travellers were more remarkable for their peculiarities than even at present. We conformed to French habits; and weak sour wines, acescent bread, and made dishes, conjoined with some excitement, which, as will appear, occurred, 
soon produced a malaise au cour in myself. So it happened likewise with an old merchant of my acquaintance, who, about the same date, translated himself, his wife, servants, and family carriage across the straits, intending to make the grand tour. His complaint, however, took the form of gout at the stomach, with irritability of temper; and, unfortunately, swearing was not then out of fashion, or at any rate with him. He feasted at Calais, Abbeville, and Amiens, on rich dishes, salads, and French wines, chuckling over the ridiculously cheap price of the claret and champagne, and giving up his old port for a little glass or two of Madeira to make all right. Alas for his cosmopolitan good nature! At Beauvais he was taken very ill; the gout was retrocedent. A physician was sent for, who prescribed a ptisan of lime-flowers; this was thought trifling with the patient, and a second man of medicine was summoned, in hopes of calomel and black draught; but a second ptisan of dog-tooth grass came from the apothecary's. The French make ptisans of the roots of two grasses, Triticum repens and Panicum dactylon. In desperation a despatch went off for a couple of English doctors from Paris, if such could be found. They came, and wisely shook their heads, observing that the French air did not suit the poor gentleman; and consequently the horses' heads were turned round, and he was driven post-haste back; the wife delighting afterwards to tell me the tale, in revenge for her own disappointment of seeing Paris life.

Passing homewards ourselves through Abbeville, a lady and her daughter appearea at the door of the diligence. 'Thank God! thank God!' exclaimed she, 'I hear an English voice.' 'Oh, yes, madam, we are all singlish here!' 'I am glad. I am going to 
England. These French! they rob you every hour. The men are all Atheists, and the women no better than they should be.' 'Perhaps, madam, the Catholics think no better of us Protestants.' 'Oh, I am a Catholic myself; but you don't call the French, Catholics, do you? They are very bad Catholics.' ' You forget our friend the Abbé, mamma,' put in the daughter. 'Oh, I suppose the Abbé was an easy confessor,' from one of us. They were English Catholics, of good birth, and we admired them so much that we were sorry to leave them at Dover. They had not lost the love of their native land with that of its national faith, nor from a prolonged residence in Picardy.

For ourselves we found that as Etudiants (which was, unfortunately, our denomination in our passports) we got snubbed. We tried the title of Doctor of Medicine, prospecting a little, but that proved a worse nom de voyage. In fact, Englishmen were no furourites. My friend had Irish blood in his veins, or I supposed he had, so we called ourselves Hibernois-a decided hit, which raised us above the Anglais, particularly with the ladies, who have a high idea of Irish gallantry. On the road to Paris we met with a young Frenchman, a shopkeeper's son, who had been to London to endeuvour to recover some debts; and he struck up a friendship with us, afterwards invited us to the house, and politely went with us to the galleries of the Louvre and Luxembourg, and being well acquainted with their contents (not then, however, what they were in the days of the empire), entertained us with loquacious disquisitions on the pictures of Rubens, Murillo, Gerard Dow, David, and Girodet; our simplicity and non-connoisseurship equally amused him. Then there was Père la Chaise 
to see, with its elegant monument of Abelard and Heloise; and the Pantheon or St. Geneviève, with the tomb of Ney, soon to become an object of enthusiasm, for shortly after, when we surveyed it, some French folks looked very savage at us, though our sympathies were with the French soldier. The church of St. Sulpice was nearer our lodgings, and we noticed, what one often sees in French churches, at least in Normandy, that the font is formed by a very large shell of Tridacna gigas, this one having been presented, it is said, to Francis I. by the republic of Venice.

These few sights being seen, and also Notre Dame of course, Messrs. les Etudiants sate down to their own particular studies in apartments in the Rue Dauphine, not far from the School of Medicine on one side, and the Pont Neuf on the other. Our maître d'hôtel was a printer to a Royalist newspaper, the 'Drapeau Blanc,' and we disconcerted him by frequenting a café over the way, the resort of liberal students of law and medicine; but on our part this was a matter of convenience on account of our breakfasts, though we there formed the acquaintance of several other students. The landlord was an old soldier of the empire, and showed us the cicatrix of a good gash of the arm, which he had received from an English sabre at Waterloo. His place was, as we afterwards found, a focus of politics and republicanism. The visits to the Paris hospitals are generally made early in the morning; ours were to La Charité and the Hôtel Dieu. At the latter was the justly celebrated Dupuytren, somewhat rough in manners, like our Abernethy, but we fancy much superior to him in learning; he was reported rather to dislike the Inglish, and elbowed them in going round the hos- 
pital most ummercifully. At La Charité was M. Roux, well up both in French and English practice. At this time it was difficult and costly to study anatomy in England, from the recent discovery of the horrid crimes which were connected with the obtaining of subjects; but summer is a bad time for its pursuit, and we were ourselves, at that time at least, imbued with a fondness for comparative anatomy and natural history. The microscope, drawing, dissecting insects, and other similar pursuits occupied much of our time. We had letters to several eminent men of science, including Cuvier and G. St. Hilaire. We found the former in his Gallery of Comparative Anatomy at the Jardin des Plantes, clad in something. like an old snuff-coloured great-coat, and in a fur cap. He was affable, and placed us under the charge of his assistant, M. Laurillard. France ranked before our country in zoology and comparative anatomy at this period. Books on the former branch of study in England consisted mostly of mere popular stuff-as indeed many of them do now, with a mixture of the grotesque or ridiculous. The London College of Surgeons was only just showing signs of vitality under Owen, though his father-in-law, Cliff, had done his best there. Hunter and Home had passed away. The British Museum had also shown little signs of life. The Monros had lectured in Scotland, and old Brookes at Blenheim Street, but were gone. Sir C. Bell often took illustrations from the above branches of science for his lectures, as indeed had Sir A. Carlyle before him; but, generally spealing, anatomical and physiological teachings were not illustrated as they ought to be. Curier was Chancellor of the University, Baron and Grand Officer of the Legion of Honour; Louis Philippe made him shortly afterwards a peer of 
France; but his career was at this time nearly orer - his love for science as intense as ever. His works are well known; the first, the 'Mémoires sur les Mollusques,' was written when he was tutor at the Château Fiquainville, near the sea, on the coast of Normandy ; the last, the great work on Fishes, he was obliged to leave to his fellow labourer, Valenciennes, to proceed with. G. St. Hilaire was a younger man, and survived Cuvier, with whom he was worthy to be considered the compeer from his enthusiastic genius and patriotism ; like Savigny, he became blind. We attended some lectures by Blainville, who had a great facility of illustrating them by extempore drawings; his class was frequented by many young ecclesiastics and by several scientific ladies. Curier's anatomical museum contained a skeleton of the gorilla, then called the pongo; the menagerie also possessed a family of the Babiroussa, and one or two fine giraffes, which were fond of browsing on the tops of the acacias. Frederick Cuvier, the baron's brother, carefully studied the habits and instincts of these and the other animals in the gardens, and has given us interesting details of them,'a subject (when carefully observed) of psychological importance. The galleries of stuffed birds and prepared fishes were unrivalled at that time. Cuvier's 'Règne Animal' formed a delightful companion in the Museum, and Richard, or Decandolle, served for the study of the living plants in the botanical parterres of the Jardin des Plantes. Within some of the flowers were several specimens of the brilliant Cetonia or Rose-beetle, which is rare in England, at least in the North. We had many rambles about the outskirts of the city, as along the Seine to Vincennes, Charenton, and the Bois de Boulogne. We found and preserved some interesting plants, a few aquatics 
from the Seine and other waters around Paris, * others from the fields and waste places, $†$ some of them not rare in the chalky parts of southern England. We gathered many of the Leguminosæ in the environs, but with regard to some of them it is difficult to say whether they are native or interlopers. Bryonia dioica was common in the Bois de Boulogne -curious at that time to us, as it did not grow in our part of England. The white declivity of Montmartre often shone in our sight, but we were not geological enough to explore it.

The mention of the Bois de Boulogne brings to remembrance a sad occurrence which happened a little later, on the only occasion that we visited the theatre, in this case the Opera or Academie Royale de Musique, and principally to hear Nourrit sing the 'Marseillaise' and 'La Parisienne,' which he did well for a Frenchman, the French, in our opinion, being neither in their voice nor as to their language equal to ourselves at a song. But the poor actor, who shortly after committed suicide, produced quite a furore with his performance, at one point kneeling and clasping some tricolors to his heart. The melancholy occurrence, however, was not the death of Nourrit, but that of a young civilian, owing to a quarrel which he had with an officer in the pit of the theatre; at first a mere dispute about the right to a seat, but aggravated by a blow from the

* Sparganam natans, Najas marina and minor, Trapa natans. Add also Zanichellia, the Arrow-leaf, the Flowering Rush, Villarsia and Hottonia.

$\uparrow$ Melampyrum cristatum, Aristolochia, Adonis, Delphinium, Ajuga chamæpitys, Stachys recti, Onouis Columnæ, Carduus crispus, Centaure: calcitrapa, Isatis tinctoria, Campanula speculum. The following also occur around Paris:-Asparagus officinalis, Tulipa sylvestris, Scilla autumnalis, Globularia vulgaris, Xanthium spinosum, Herniaria, Bupleura, Cucubalus baccifor, Gypsophila. 
militaire. A meeting was immediately arranged for the Bois de Boulogne, and we saw by the journal of the next morning that the rencontre ended in the death of the young civilian, who was run through; he was one of the popular writer's of the day.

Our pleasant pursuits were now almost put a stop to by unexpected political events. We had shortly before been present in Notre Dame on the occasion of the 'Te Deum' being sung for the taking of Algiers. On this day Charles $\mathrm{X}$. seemed popular enough, and we were rather peremptorily requested to lower our hats, and render due respect to the occasion, as the cortège approached in carriages of state, equalling those of Lord Mayor's day in England. The Princess Louisa of Orleans looked the most peerless lady of the party, as she walked stately up the aisle in black velvet hat, with white plume and diamond ornament, afterwards to become a king's daughter, and then a queen herself, the second wife of the consort of our Princess Charlotte. To have beheld so graceful and high-born a creature was a temptation to poesy-

\section{Lines on a Princess.}

We beheld thee amidst the glittering throng,

Array'd at a ling's behest,

And when courtier and beauty pass'd along,

The eye upon thee would rest;

For many a baneful passion and care

Had furrow'd the brows of most that were there,

And we thought thee of happier lind, misplac'd,

For peace in thy gentle mien we trac'd,

And the smile of thy lips, the soft light of thine eye,

Bespoke that thy heart had glad feelings nigh.

Glory was won, the anthem's strain

Swell'd through the aisles of that old fane.

We gaz'd on the monarch-what feelings were there!

He bow'd, but 'twas most, we opin'd, from care. 
On the courtier too, 'twas hard to trace

The semblance of praise in carriage or face;

On the warrior next, he scorned to lineel,

For hard is the soldier's heart and steel;

$\mathrm{Or}^{\mathrm{r}}$ he might have been thinking of days gone by,

And of one who once led lim to rictory;

Then our eyes turn'd to thee, and devotion shone

In each look, as was offer'd thine orison.

In the dwelling of woe, we saw thee again,

At the pallet of sickness and pain;

Thine eye was now moist with the pitying tear,

And fled from thy cheek was the rose late there;

'Twas the tender and womanly heart with thee!

With others, we thought, but pageantry.

But, ladye, farewell! and be peace thy lot, And the good in heav'n, that on earth is not.

We saw Charles afterwards in a religious procession, apparently led along by the Ecclesiastics, stooping and careworn, as indeed well he might be, could he have foreseen his near destiny. A tyrannical ord́onnance came out, a printing-press was seized, there was an émeute, and one of the rioters was cut down, and his body paraded by his friends through the streets. We passed the party, and heard their execrations, but were hardly prepared for what followed. In the evening of the same day I was passing through a distant part of Paris, and got wrong in my topography, finding myself in an eastern faubourg, where every street was dark, and in process of being barricaded at the ends; only getting right at length by pushing down to the river, which served as a guide home. Most young men are at one time or other liberals, but knowing the language imperfectly, I even feared to enquire my way or enter into conversation, as swords were flashing about me, and firearms popping off occasionally. When I reached 
home, I found that M. of the Drapeau Blanc had become afraid of his colours, and he locked up himself and his lodgers in their apartments, at the risk in our case of being starved. There was unusual commotion at the café on the opposite side of the street, and a barricade was formed close at hand by pavingstones, capsized fiacres and omnibuses; stones also were taken to the tops of the houses to throw down on the troops. We sate at the windows and safely saw how matters went on, though an English student of our acquaintance, more meddlesome, was shot through the head. For two or three days and nights the firing was incessant, except for an hour or two at early morning, when there seemed to be a lull in the angry passions of the combatants. We could occasionally see a little fighting on the bridge to the left, and there, we were told, was stationed Marmont, wavering between the cause of the king and that of the people, the latter, however, soon prevailing. Many dead and wounded were carried past under our windows. There was very little drunkenness, but several profane fellows put on the robes of the ecclesiastics; and we noticed a few females, even some young ones, hideous enough in their excitement, with knives or pistols, several marching in from the country amongst the ranks. When the day was won, as other patriots before us have done, we went out to reconnoitre. Though of no fighting turn, we showed our love of liberty, as well as our spite against our domestic tyrant, M. of the Drapeau Blanc, in fierce verses; for instance, in the following :-

To the Tricolor Flag.

Once again, lov'd banner! stream

O'er our patriot bands on high ;

Once again, bright banner! beam

Triumph, glory, liberty. 
Now of time and thought the hour,

Wave and ue'er again be furl'd!

See from fane, and dome, and tower,

Bourbon's pallid badge is hurl'd.

Hail, thou flag of colours three!

Victory dyed thee as she wove;

Dyed thee, first like deepest sea,

Or the zenith blue abore;

Midway white, without a stain,

Or with Vive la Charte impress'd;

Dipp'd in crimson, there again, From the dying Frenchman's breast.

How it triumph'd o'er our foes,

Ask the hero to impart,

Ask the patriot-well he knows

Whence the life-pulse of his heart.

Mauy fine buildings were battered severely. The venerable La Fayette was summoned and obeyed the call; then Louis Philippe also appeared, who came forward, like ourselves, when all was well settled; and in accepting him for their future king, the French seemed much in statu quo. Many sensational affairs followed, as well they might; the ears were deafened with the grinding of patriotic hymns on the barrelorgans; there were public obsequies; and the hospitals, where were the wounded of the three days, were visited by the Duchess of Orleans in state, and she and her daughters dressed the wounded with their own hands. Every hour had Louis Philippe to doff his white hat to the populace at the Palais Royal, and we concluded that he would be king as long as he lived. Every Frenchman became a hero; la gloire and la patrie were in every mouth. Of course we could not enter into all this, and grew tired, though we attended at the hospitals. There were rows 
of patients shot throngh, minus a leg or arm, or otherwise mutilated in the fray.

Late in August we determined to leave the French to themselves, and early one morning departed from Paris on its east side, ensconced in the banquette of the diligence, in search of the picturesque. We had heard of the Rhine, but knew little about it, or where its fine scenery lay, thinking if we only got to the. river that was enough. The horrors of the journey were bad, but Château Thierry, which we passed on the evening of the first day, was a pretty place on the banks of the Marne. At Nancy I almost expected that my travels would have come to an end. I would have it to be from bad water and acescent diet; my friend taxed me with gourmandrie, not forgetting a glass or two of champagne. We were here in the heart of the champagne district, and the charge at the inn was about three francs the bottle. We saw little of the place, though we made a short stay. A rest of a day or two at Strasburg caused me to revive and look around. The ramparts designed by Vauban were bristling with cannon ready for all comers. Of course we visited the cathedral, having a spire of immense height and of wonderful lacework in stone, and the west front very richly ornamented. At the church of St. Thomas is the monument of Marshal Saxe ; Kleber also rests under a monument in the Place Kleber; and Desaix, another of Buonaparte's generals, has a cenotaph between the city and Kehl. The public collections of Strasburg are rich in fossils, antiquities, manuscripts, and early printed books; indeed the city claims the honour of the invention of printing, and has raised a monument to Gutenberg, its reputed originator. The people seem quite as much German as French. Strasburg was seized upon by 
the latter nation in time of peace, but the course of the Rhine seems to give them a natural right to the place.

In a day or two we proceeded on foot up the Rhine, passing over the bridge of boats at Kehl; however, the road runs at some distance from the river, and I doubt whether we saw it again till we crossed it at Basle. The road often passed by or near vineyards, and apples and plums were grown in plenty, and were drying before every house for preserration; there were also fields of tobacco, which was therefore clieap enough to tempt one to indulge. We passed one or two castle-crested crags, but found that we had missed the more picturesque part of the river. One ruin overhung the road, and aloft a kite was flitting, which we recognised by its forked tail. My friend's anger was kindled at the sight of the Calvaries which occurred on the roadside; rather startling;, certainly. The weak white wine of the district was very cheap and very refreshing. The country people seemed to live principally on bread and curds. The houses were often large, with abundance of windows, having rows of them in the roofs. We made sketches at picturesque points. The distant pine-topped and occasionally castle-crowned hills were at the western extremity of the Black Forest; and at Freyburg, after viewing the fine cathedral, we struck eastwards in search of adventure, and of the sources of the Danube, which are hereabout, but without meeting with either. $\mathrm{My}_{\mathrm{y}}$ friend was, at starting, a bad, walker, being muscular and heary, and with tender feet; he tried shoes without stocking's, stockings without shoes, and feet without either, before they finally got hardened. In the Rhine valley numerous little streams crossed our route, falling into the main river; great quantities of 
flax were being steeped in them, causing an effect by no means agreeable to the smell; they abounded in fish, which were easily caught, but they were of little worth-dace or chub. We had a walking-stick fishing-rod, blouses, and knapsacks, with a Keller's map; and I carried a cork-lined insect-box, which I took home pretty full, some of the specimens still continuing, after many years, in fair condition, more injured by changes of domicile or repinnings than by the effect of time or light.

Crossing a shady and verdant-banked river, the Weissen, we entered Switzerland, after a walk of about one hundred miles on the Rhine, taking us four days to do it, near the old town of Basle, a name familiar to bibliopolists. The inn where we put up (on this occasion first rate) was, I think, the Savagethe Angel it might have been; but whatever was its name, it had one of the old enclosed and galleried quadrangles so common in ancient times at inns in England. The table d'hôte was a very tedious affair. We walked to the cathedral, built of not very pleasing stone, nor very beautiful in its architecture, but of interest from containing the tomb of Erasmus, and in a neighbouring hall was held the Council of Basle. Paracelsus, the prince of charlatans, lectured at Basle, commencing his course by burning the works of Galen and Avicenna over brimstone, in a brazen chafingdish, exclaiming, Sic vos ardebitis in gehennâ. Basle lays claim to be the birth-place of Holbein, and several of his works exist here, painted before his sojourn in England. Here, too, were born and lectured several of the Bernoullis and Euler. The scientific collections, botanic garden, museum of antiquities and libraries were at this time, at any rate, in advance. To the south-east of the town is the battle-field of St. Jacob, 
where the Swiss, in 1444 , bled in defence of their liberty.*

We left the town on the following afternoon after our entry, and walked south-east, putting up for the night at a curious little walled town on the Ergolz, called Liechstall. The afternoon was stormy, and the skies changeful, with fits of sunshine, but this gave a vivid freshness to the scene. This tempted us also to make a sketch of the fortified town or village, with its little spired church, walls, towers, and gates. At the hostelry was a party of similar students to ourselves, from some German university; also several tradesmen of the town, one or two of whom spoke a little English. We could not do less than fraternise-in fact I fear we became too hilarious for our philosophical pretensions, and after drinking prosperity to the important town where we were, to the English, Schweiz, the Fatherland, and the Grande Nation in glasses of kirschwasser, and with increasing benignity, we got well into the night; indeed we found that sobriety was not a virtue of the Swiss; we saw more breaches of it there than in England, especially on Sundays. We also saw at our party that the leaven of French politics was at work here. Shortly after things came to a crisis; on one side was Basle city, on the other the canton with Liechstall, and much blood was shed near this little place. It struck us (right or wrong) that in the Protestant cantons of Switzerland there was more thrift and cleanliness, but, as a set-off, sharper practice with travellers, whilst in the Popish districts there was dirt and poverty enough, but, as a

* The following plants may be found around Basle:-Iris Germanica, Globularia rulgaris, Physalis Alkekenge, Heliotrope, Eryngium campestrc, Xanthium strumarium, and many interesting aquatic species. 
rule, more honest charges. The authorities seemed tyrannical, and many simple things were tabooed in this free republic. On one occasion we caught a batch of trout and took them to a wayside inn, where there happened to be imbibing one of the small authorities, of a meddlesome disposition, and he, backed by the landlord, endeavoured to get up an anti-English feeling, not without an eye to the fish; and one other limb of the law even displayed the butt-end of a pistol which he had in his pocket. My friend, however, bawled as loud as they, and we rose up to lead the way to the Bailli, first, however, walking in front of the house and taking down the name of the inn and of the landlord, promising to have him entered into the books of all the hotels in Switzerland as a rascal-a proceeding which silenced him at least. The country became more picturesque as we entered a portion of the canton of Solothurn, passing a little church on the wayside at Langenbrugg, ${ }^{*}$ with a ruin at a little distance on the hill. The church was no very elegant specimen of a village church; the windows were mean, the roof and tower covered with red tiles, and a little spired belfry on the saddleshaped top of the latter. Further on there was a more remarkable castle, called Falkenstein, on the summit of an apparently inaccessible rock to our right hand, once the stronghold of a fierce and tyrannical enemy to Swiss independence.t Basle is a Protestant canton, Solothurn Popish. Further on was a narrowish defile, with another castle, or something of the sort, Blauenstein, on the left-hand eminence. We saw many large greenish lizards

* Melittis melissophyllum and Melissa officinalis grow on this spot.

$\uparrow$ Mespilus amelanchier and M. cotoneaster occur here. 
here, but could not secure one.* Towards evening the horus and voices of the goat- or cow-herds made very enchanting vesper music on the hills in the distance. We passed a pretty cottage residence, and could have sworn that the young ladies in front were English, and were half inclined to address them. At one point we saw another young damsel approaching, very short in petticoats, and decked out much like an rpera-dancer; we fancied this was the holiday costume of Solothurn. Further on, the dress was more sombre, the bodice laced, black net coiffure, or something of the sort, and the hair with double cue behind, the Bernese toilette; but we were not particularly observant in many such points, or have forgotten them. Our quarters once or twice in the north of the Confederacy were none of the best, sleeping between two hot beds in large rooms, with other company, and occasionally none of the best; drunken brawls occurring, rivalling English ones. We got to Solothurn on a fair or market-day. The town is walled, and the entrance gate had been peppered with bullets in some attack. Here popery and monachism flourish. We peeped into the cathedral and saw abundance of tawdry tinsel. Abbé Hugi made a fine collection of oolitic fossils in the district, and the town has made the purchase of these. $\dagger$ Throughout Switzerland rifle-shooting was

* Probably they were Lacerta ocellata. We have kept L. viridis (of which, according to Cuvier, L. bilineata is a varicty) for a year or two in a Wardian case, which must have been, during one winter, of a temperature as low as freczing. They are interesting little crentures, but from their great agility apt to escape; they bite, but their minute teeth are harmless; they are ready to come to the hand for a fly or a worm, of which they eat numbers. They are fond of the sun, at other times hiding themselves in holes which they hollow out deeply at the bottom of the case.

+ In the Bull. de la Soc. Bot. de France, tom. riii., is a paper by 
the rage, as it has been with us since. On our way to Berne we passed an ugly pillar, with an inscription on the square top, telling us that on St. John the Erangelist's day, 1375, on that spot the Bernese defeated an English army under the command of Enguerrand Sire de Couci, Signor Picard et gendre d'Edward III. 'A lie!' said my companion, hurling a stone at it; 'I should like to see these fellows beat the English.' I fancy most nations can better enumerate the battles they have won than those they have lost.

At Berne the arrangements of the streets and houses remind one of Chester; there are many fountains, and the streams from them run down the middles of the streets. The fountains, as well as the clocks, \&c., have often curious sculptures, for which the Bernese seem to have a natural taste. The public institutions are numerous; such are the hospitals, museums, and the library, where Haller the poet, naturalist, physiologist, and physician studied, too tender-hearted, however, to bear the sight of living blood. The collections, as might be expected, are now very different from what they were at the era of our visit, owing to the labours of M. Studer and others. We did not see the bears, but paintings and carvings of the animal were common enough throughout the canton. There is a fine view from the cathedral, which architecturally surpasses that of Basle; the view takes in the Bernese and Ober Wallis Alps,

M. Chatin descriptive of a grand herborisation in Saroy and Switzerland, 1860 , accompanied by about 200 pupils and companions. It is a very interesting and lively paper, the route taken being exactly the same as our own, except that they visited the Great St. Bernard, and also the Weisenstein, near Solothurn. In the last locality they fourd Daphne alpina, Biscutella levigata, Alnus riridis, Spiræa aruncus, Imperatoria ostruthium, Iberis saxatilis, Digitalis luten, Erinus alpinus, Globularia cordifolia and nudicaulis, with others less interesting. . 
the Wetterhorn, Schrekhorn, Finsteraarhorn, Jungfrau, the Blumlis Alps, and the Doldenhorn. The first sight of these mountains is extremely striking; indeed, when seen first from a nearer point, one may miss them for a short time by looking for them at too low a level. The Aar almost encircles the city. On our road we had picked a few plants, but they were principally roadside strays.* The mosquitoes or gnats were very bloodthirsty about Berne, and their curious proceeding:s could be well seen by the lens, piercing very adroitly our skins, and soon filling themselves at our expense. The rain, which these proceedings foretold, came on most decidedly the following day.

On towards Thun, and when we got near we sketched it, then ascended its streets to the church and castle, and admired the view below. Here the climate is good and genial, and the spring early. The walnut is much prized for the sake of its oil. We followed the road near the south side of the lake, resting at a very respectable inn standing by itself. A spit of land stretched into the lake, and standing on it we canght a quantity of very beautiful little fish, with silvery sides and blue backs, we should suppose Coregonus murcenula or vendace, but as that is said not to rise at the fly, they were possibly bleak. There was no rest for the writer on the following as well as on other nights, having to sit up most of the hours on the bedside; however, our quarters were clean and good, and my friend could not tax me with imprudence. We both agreed that pedestrianism was rather hard work, too hard for the greatest

* Around Berne are found Primula farinosa and Cypripedium calceolus, Dipsacus pilosus, Centaurea calcitrapa, Ornitlogalum nutans, Malra moschata. 
amount of enjoyment, and for the aequirement of the greatest amount of knowledge.* All the route from Strasburg to Geneva was done on foot with the exception of a short ride as a finale. Next day we passed a river falling into the lake by a curious covered bridge of wood; above it was formed a fine cascade, or rather rocky torrent, with the Niesen seen beyond the pine-topped rocks. We believe, however, that this ravine is artificial, being cut in 1714. We sketched the rocks, but their particular formation was not examined. A village named Frutigen came next, and then ascending a valley, which reminded one of a Derbyshire scene, we came to another village called Kandersteg. The torrents in these valleys brought down stones of enormous size. The Meadow Saffron abounded in the rich little fields, and looked gay enough, being in full flower. We disturbed one or two squirrels of a different species, or variety at any rate, to ours, being black, or nearly so. The rain came on, and we stopped at the last-named place, at an auberge where there was but scanty fare; the house itself, however, was an interesting specimen of a, Swiss chalet. There were several waterfalls up a side-valley called Gasternthal, to which we walked in the evening. Below them we saw some fish rising freely at little white crepuscular: moths, and we easily imitated the latter with a white feather or two which we found, thus

* Our herbarium contanns many plants found about Thun; some are rare in Great Britain, some not found there. In Loudon's Magazine there is also an account of Thun botany by Mr. Brown. Interesting species are Convallaria bifolia, Astragalus glabra, Dianthus plumaria, Pulmonaria, Aconitum napellus and lycoctonum, Impatiens noli-metangere, Astrantia major, Polygala chamæbuxus, Gentiana purpures, Buplerum ranunculoides, Linaria alpina, Trientalis Europæa, and on the higher Alps many others. 
securing a dish of fish-we believe they were the Salmo alpinus. My Lord - (we forget his title) was detained with a party of ladies by the weather, and quite disconcerted by the scant fare, and we obtained his good graces by sharing the proceeds of our rod. The boors around kept up an incessant din by hammering their scythes, we supposed to harden them.

Next day we determined to pass the Gemmi; we could not afford a guide, so set out without one by the map alone. Unfortunately we very stupidly took the wrong turn-to the right instead of the leftafter leaving the village; we passed through a bit of forest, and over the swollen river by a wooden handbridge; we next went on between two mountains, as long as the track served us, but higher up it quite died out, and heavy rain and snow came on. Above we could just discern a huge cliff through the thick atinosphere, where 'the frighted eagle screamed and passed by.' We wandered bewildered, considering. how we should like a night out, till we came to a miserable hut; we looked in, and amidst the smoke, at a bit of fire, with a kettle, stood a wretched man, goitrous and non compos. He was evidently frightened at us, and took up a hatchet. In vain we enquired the road; he gesticulated wildly, but we could get nothing out of him. We thought it best to return-more easily thought of than accomplished, for we could not find the spot with the bridge again. My friend slipped down a rough declivity, and fairly finished off his nether garment, which we were obliged to fasten together with one or two extemporised stitches and by the help of some entomological pins. At length a fallen tree helped us across the river, and we were glad to get back to the inn from 
which we had set out. Of course gibes were endured, but what was worse, my friend had to be new rigged out and tailors were scarce; at last the landlord let him have his holiday trousers as a favour. They were à la gigot, narrow below and expanded above, and they would have been just the thing a quarter of a century later, but then absurd enough, so imperious is fashion. I told my friend he now looked more like Venus than Mars, but it was dangerous to joke on the subject. We started afresh the next day, and were doubtful of the path again, when we saw a gentleman dashing down a bank towards us, and he had evidently descended from the pass; we therefore asked the route from him in French first, such as it was, but he shook his head; my friend tried his German-another shake; and we thought of trying Latin-Magister or Domine dic nobis-when he said, in despair, 'Can you speak English?' He was in fact a countryman of our own. A foreigner tells an Englishman more easily; for a friend, who prided himself on his foreign cut, told me that he was standing in Paris opposite a bookseller's window, reading the titles of the French works, when the bookseller stepped to the door, and, bowing low, invited the gentleman in, telling lim he had plenty of 'de Englisch books within.' In ascending the Gemmi some fertile bushy ground is first passed, prolific in plants-two or three medicinal ones, an Aconite, white Hellebore, Gentian, Mezereum, and others.* A village was passed in a valley, and then the scenery became wild, with a small lake, the Daubensee, seen amidst the barren Blumlis Alps. There was no vegetation, or little, but the

* Dr. Chatin mentions also Pyrola minor, Astrantia major and minor, Centaurea montana, Thalictrum aquilegifolia, Lilium martagon, Tussilago nivea, Primula auricula, Anomono alpina. 
ground was covered with a thin sprinkling of snow, contrasting with the black scattered rocks and the dark gloomy lake. We slept at a little inn of a rather dubious reputation. Our quarters were a veritable loft: in fact the spot seemed just the place for robbers; we might be murdered and disposed of in the lake, but then we considered that we carried no inducements, and probably were more banditlooking ourselves than the people of the inn. The pass of the Gemmi is curious, and was only made passable by some miners in 1741 ; it is 7,540 feet abore sea-level, and the lake is nearly as high, 7,280 feet, one of the highest in the Alps, if not the highest.* It is the descent that is remarkable, the path being cut in the sides of high precipitous cliffs, often with a deep abyss at its margin ; yet even here the miner had reared his scaffolding, and was at work on the sides of the perpendicular walls; and invalids are carried down in litters to the baths below, their eyes being covered at certain points. This road can hardly be supposed to exist, looking up from the baths of Leuk below. The waters of these baths, as they rise from the earth, are too hot $\left(124^{\circ} \mathrm{Fahr}\right.$.) to use, and must cool first. Yet Mr. Murray (not the author of the Guide) says they contain a conferva, and also larræ of Musca chamceleon. Men and women sit in them pell-mell for hours, but of course in bath dresses, amusing themselves as they can with floating tables before them. The village is at the summit of one of the deep side-valleys embouchuring into that of the Rhone-the Vallais; and looking downwards

* On the higher part of the Gemmi ocenr Erica carnca, Aretostaphylos, Oxytropis montana and campestris, Salix retusa, Saxifraga oppositifolia, Dryas octopetala, Alchemilla alpina, Aster alpinus, Aretia Helvetica, and Rhododendron ferrugineum and hirsutum. 
there is a fine view of part of the southern mountainous barrier of the last valley, including Mount Rosa, or at any rate its nearest neighbours. Down the valley of Leuk we walked, choosing for the latter part of the way the bed of the river; on the right might be seen scaffolding or ladders attached to the sides of the rocks, leading to a mountainous hamlet, Albinen, higher up, and above and before us was the road which led from the west, crossing the river or torrent-bed by a high bridge. It led into the neighbouring town of Leuk, and the bridge had a gateway with two towers upon it.

We should now have turned to the left up the Vallais, and have gone on to Brieg, and then ascended the Simplon, but our purses were light and our feet tired. We noticed that some of the tributaries of the Rhone were white as milk with the earthy matter contained, and the question occurs whether this has anything to do with the prevalence of goitre and cretinism here. Descending the Vallais, first comes Siden, and then Sion or Sitten; the latter with its eastellated cliffs forming a magnificent view. The buildings which crown the detached rocks are various - the castles Valeria and Majoria, the bishop's palace, and the old cathedral, as well as the present city, most westwards, the whole rising from a flat and marshy plain, abounding in luxuriant aquatic plants and Cyperaceæ. We were served with chamois venison at the hotel, not without suspicion that we were eating goat flesh or old mutton. The valley was very hot and oppressive, and abounded in insects, particularly highly-coloured butterflies, many of them, indeed, being southern species, and not found northwards. In fact here a new or transalpine type of natural objects may be noticed; the vine, the fig, 
the mulberry, and the alnond abound; the pomegranate and the Indian fig flourish; the latter half wild. A chasseur showed us an Alpine hare which. he had just shot on the mountain side. We attempted to fish in the Rhone, but it was rapid, swollen, and muddy; and we only took two or three little fish as long as the finger, I think nothing uncommon. In winter bears and wolves make predatory excursions, and there are marmots on the mountains. The beeeater and the ortolan are found here. The terrestrial salamander, S. maculosa, as well as a black variety of $i t$, and the tree-frog also are native; and we noticed Cicadx in a row of trees.*

We left Sitten, once the scene of princely ecclesiastical greatness, but now of misery and decay, and tramped down the hot and marshy valley till we came to Martigny. $\dagger$ At this place the Rhone turns to the right to course towards the Lake of Geneva, and here is the tower of an old feudal fortress, perched on a rock above the village. As we followed the turn of the valley with the eye, a very fine waterfall was caught sight of, with a very absurd name. The mountains here on each side the river are high and abrupt; and further down is the bridge of St. Maurice, the only practicable road into the valley on this side. Leaving Martigny, we followed

* We have specimens of Stipa pennata, Aconitum authora, Artemisia vallesiaca and Ononis natrix from the Vallais. Spirea salicifolia, Sparfium radiatum, Artemisia glacialis, Coronilla coronata, Adonis vernalis, Matthiola tristis and Asparagus are also Wallisian plants. M. Chatin found Eruca sativa, also Xeranthemum inapertum and Andropogon Ischæmum, southern forms, and Gentiana ciliata.

+ Lencanthemum maximum, Soldanella repens, and Artenisia absinthium grow in the lower ralley; the latter is collected to manufacture the celebrated but pernicious Parisian Absinthe, 'agréablo et perfide, qui tue plus d'hommes distingués que le boulet.' $-M$. Chatin. 
up the dreary valley of the Drance, and in the débris about noticed some of the effects of the great inundation in 1818, so disastrous to the inhabitants of Martigny and of other villages. An avalanche from the glacier of Getroz had blocked up the river, and before the ice-dam of the lake so formed could be cut through, and the waters let off gradually, it gave way with a sudden rush. Following up the river is the road to the Great St. Bernard.* After crossing some high ground, and passing a curious shrine holding out sundry promises of indulgences, we came to a village in the picturesque valley of Trient, where we refreshed the inner man, and where, if we could have believed the entry of one of his friends in the visitor's book, D. O'Connell had done so before : we read that he 'Dined here' on such a day, 'but left without paying the shot.' We might now have entered the valley of Chamouny by a lower route called the Valorsine and Tête-noir, but we preferred a higher pass, the Col de Balme. We were without a guide, ascending at first through a forest of larch and pine, covered with pendulous stringy lichens. $\dagger$

* From this valley I have Phyteuma orbiculare, Dianthus cæsius, Arenaria polygonoides, Delphinium consolida, Saxifraga stellaris and S. crespitosa, the Colchicum (Martigny), Geranium pyrenaicum (Orsières); also Epilobium angustissimum, Digitalis sp., Potentilla argentea, Campanula sp., and the common Corncockle and Bluebottle. M. Chatin gives MIelica Nebrodensis, Saxifraga aizoides, Selaginella Helvetica, Dianthus sylvestris, Rumex alpinus, Hippophae, Anemone alpina, Meum atlamanticum.

† Of the pines, the larch has the highest limit in Switzerland, ascending to $7,000 \mathrm{ft}$. abore the sea ; the $P$. abies does not ascend so high by $2,000 \mathrm{ft}$., and the P. picea has a still lower limit. P. sylvestris is a lowland species, often found, as with us, in marshes. P. mughus has a wide range, ascending much higher than the last. P. cembra and the larch are uncommon in North Switzerland; the former ascends very high on the southern Alps. The birch and even the beech surpass P. sylvestris in the height of their limit. Alnus riridis equals the larch: and 
Here we saw a specimen of the Apollo butterfly.* Further on we came to a mountain plateau, with a precipice on the right hand, and the surface deeply covered with snow newly fallen-luckily, however, presenting some footsteps of man and mule, which served for our guide to the châlet or little inn kept by an honest. Savoyard. An Englishman had been staying some days to get the view of Mont Blanc, and in despair had just left; it was before us now in full glory, its broad base making the back of the picture, and stretching out to the right embosomerl in seas of glaciers, its head clear and sharp to the point; below us the Col shelving down, and further on the deep valley of Chamouny, with one or two hamlets, La Tour and Argentère; then glaciers to the left, of the same name as those villages and approaching pretty near, and also a wilderness of Alpine scenery, with aiguilles or sharply-peaked mountains, Aiguille Verte, de Drû, and Charmoz, \&c. ; whilst to the right were other aiguilles (Rouges), apparently, though not really, shooting upwards from the nearer foreground, and further away Monts Brévent and Buet. The Col de Balme is about as high as the pass of the Gemmi, far below some of the higher Alpine passages of Switzerland. We slept at the châlet, and late at night were called out by our

Empetrum nigrum surpasses both. Rye and barley are grown as high as $4,000 \mathrm{ft}$. abore the sea, or higher. Fruit trees grow at from 1,000 to $2,000 \mathrm{ft}$., the vine at from 800 to $1,800 \mathrm{ft}$ - - Helvetiens Flora, Suter.

* The collection of the author contains the following Lepidoptera from this part of Switzerland:-Diurnal: Papilio Podalirius, Colias lyale, Mancipium duplidica, Apatura iris, Apatura sp., Limenitis camilla, Thecla betulæe, T. quercus, Vanessa levana, V. prorsa. Moths: Ourapteryx sumbucaria, Cotocalia fraxini, C. nupta, Plusia chrysites, Thyatira batis, Biston botularia, Aretia fuliginosa, Chelonia purpura, Turtrix prasinea, Cerura sp., and others. 
host to survey the scene by starlight; the spangled vault, the solemn silence, the sublime landscape produced in toto sublimity.

\section{The Alps.}

The Alps, the Alps, the mountain wilderness!

My homage take! though dear my native land,

I scarce would wish to laud or love you less:

Wrapp'd in your flitting robes of cloud ye stand,

And alb of ice perennial, whilst repose,

Far above dross of earth, your summits crown'd with snows.

And now, befriended by the starry night,

I gaze around upon the scene sublime;

No sound! save that some distant stream, from height,

Dashes to deep ravine; or another time

Some noise unearthly, strange, startles the ear,

I know not whence-from height or depth-far off or near.

Above, below, sleep peak and ridge and vale-

Sleep, said I? no ; they're all awake to praise!

'Tis man that sleeps-sleepless they tell the tale-

Creation's tale, and voiceless incense raise;

And ye, bright host! yon vault that spangle o'er,

$Y e$ are the mystic eyes that rest not but adore.

I leave the stifling hut for mountain air-

Ether, not air, so thin and cool and pure ;

Ah! here I'm high indeed! my fellows there

Far down below; a poltroon I'll be, sure,

Not to be great! A king? but subjects lack,

And kings deserted find that 'tis high time to pack.

No crown for me! why then I'll take some tool

And grub at rock; and tell how worlds came first.

Alus! in such a scene one feels a fool,

Though in all learned things and names well vers'd,

But liard they are to put in lines laconic-

Those ups, and downs, and-so must end my lines Byronic.

A bottle of sweet red vin d'Asti did us good, as we found it difficult to keep warm. The host collected Alpine plants and insects, as well as mine- 
rals, and had a little museum in a back room. There were the horns of the chamois converted into boot-hooks; ear pendants, and other ornaments in smoky quartz; and various curiosities besides. I picked myself, or had given me, a few plants.* As we descended the next day, one of the larger Falconidx dashed out of a little deserted hut which lay in our way. We stayed a day at Chamouny; the road to it passes very near the termination or lowest part of the glacier des Bois, which, higher up and more southwards, is called the Mer de Glace; its moraines are close to the road, and the small river Arveiron issues from under the glacier. $\dagger$ This last spot is one of the short excursions from Chamouny, also the Flegère and the Montanvert, the former on the opposite side of the valley. Every one climbs to the last eminence, situated on the south side of the valley; the walk is about three miles of climbing. A friend gave us a beautiful Vanessa Antiope, caught by himself here. The Jardin is a more magnificent undertaking, at least was thought so in former times; the ascent of Mont Blanc great indeed, and only for heroes, though the feat has made a few heroines. From the Montanvert, $\ddagger$ there

* Rhododendron ferrugincum, Hippocrepis comosi, Carex atrata, Phyteuma orbicularis, Bartzia alpina, Euphrasia alpina, Lascrpitium simplex, Plantago alpina, Vaccinium uliginosum, Anemone narcissiflora, Arnica montana, Tussilago alpina, Parnassia palustris, Androsace lactea and carnea, Phleum alpinum. My old friend, Dr. Murray, also gives Salix reticulata and herbacea, Rosa alpina, Eriophorum alpinum, Gentiana Bararica and rerna, and Teucrium montanum.

$\uparrow$ The Linnæa borealis is found in the Tête-noir pass. Dracocephalum Ruyschiana is found at the higher part of the Chamouny valley; also Sempervivum arachnoideum and montanum, and Trifolium thymifolium. -Chatin.

$\ddagger$ On the Montanvert the most interesting plants are Rhododendron ferrugincum, Anemone hcpatica, Viola biflora, Potentilla aurea, Azalea procumbens, Ranunculus glacialis, Cerastium lanatum, and Soldanclla alpina. 
is an easy descent to the Mer de Glace, and the view is sublime. The Jardin is a rocky ledge situated higher on the glacier, or rather on one of the several glaciers which by their union form the Mer de Glace. The one in question, called Taléfre, must, with the rock or island which it embraces, form a secluded and solemn scene, surrounded almost on all sides by impassable rocky peaks and aiguilles. Prof. Forbes's account of this icy wilderness is very interestingof the structure of glaciers, their movements, crevasses, and moraines; and so is Saussure's book on the district generally, though the 'Voyages' are not often looked into by the generality of readers. Saussure passed many days on the lofty Col de Géant, and made valuable observations there-an eminence, indeed, which of late years several English ladies have reached. Dr. Murray gives an interesting account of his visit to the Jardin accompanied by his wife.* In the village museum were specimens of the ibex or bouquetin of the Alps, which they told us was very rare, and forbidden to be killed. We turned our backs on Chamouny, seeing much too little of it, and with regret at leaving it so soon, and in after years felt more regret still. The Arve river, which we followed, joins the Rhone only after the latter has made its exit from the Lake of Geneva. The road was fine and romantic; the views of the glaciers and mountains, looking to our left and backwards, were grand. The glacier Bossons, one of the most interesting for its peculiar pillared appearances, was at one point close at hand to the left, massive pyramids of ice appearing amongst the trees. The ascent

* The plants enumerated by Dr. Murray as growing at the Jardin are Salix helvetica, Juncus Jacquini, Silene acaulis, Gentiana nivalis, Achillæa nana, Trifolium alpinum, Senecio incanus, and Geranium nodosum. 
to Mont Blanc is commonly made by following its right margin. We passed Servoz, where we stopped, and where was an interesting collection of natural history; hence is a fine view of Mont Blanc; then came Maglan and Cluse. At one point turning off a little from the road to the right hand, in a romantic spot below the road, is a monument erected to the memory of a Dane, M. Eschen, who lost his life in a crevasse on the Buet. The route towards Geneva, whither we were wending our way, passes another town, Bonneville, still following the direction of the river, and also passing near several minor mountain ridges, the Mole, Brezon, Salève, \&c. The road, however, though pretty and interesting, became tamer; we roted that we had done walking enough, and got a cheap ride to Geneva.*

Geneva itself, exclusive of the lake, is not particularly interesting. The young are seldom in deep love with Calvinism, and one does not easily forgive the great reformer for his treatment of Servetus, it may be as good a man as himself. Decandolle was at Geneva, and we did not fail to visit the Botanic Garden, the scene of his labours. How long will it be before England, with her ways and means, and her horticultural, botanical and other materials, will have gardens, museums, libraries, colleges and their concomitants, at her large towns, such as we see in every city abroad? In such respects we are truly in the rear. We passed a Sunday at Geneva. With most people Sundays abroad are unedifying; whether religious much or little, one feels out of

* Digitalis grandiflora, Actæa spicata, Leucojum rernum, Asarum Europæum, Tofieldia reticulata, Oxyria digyma, and Gentiana lutea, 'lit superbe reine des Alpes,' are enumerated, amongst other species, by M. Chatin, as found on this side of Genera. 
joint. Often the best oratory and temple on such occasions is the retired grove or hillside, where we can commune with God in his works, and in his revelations, and be undisturbed by the religious peculiarities of others-for they do discompose one, spite of ourselves, and though we may have no serious quarrel with them. At Geneva there is a curious medley of strict frigidity, and its natural rebound lax dissipation. On Sundays there are fêtes, as in Paris, and steamers go round the lake; Lausanne, Vevay, Clarens, Chillon, and Villeneuve are thus cheaply seen. The lake itself never freezes, for it is very deep in places; it is muddy at times where the Phone enters, clear and dark blue further onwards. The north shore is the margin of an extended plain, all fertility and beanty; the south more abrupt and rocky, particularly at its upper end. It is fullest in the summer, on account of the melting of the snow. The pelican occasionally frequents it; and it abounds in fish. One large salmon we partook of at the table d'hôte at the inn l'Ecu de Genève-the only good meal we had eaten since we left Basle; the fish, however, was rather unsatisfactory, and only half-salmoncoloured.* Many very interesting plants are found in the vicinity of the city. + The lynx is said not to be extinct, and certainly not the bear, and the Mantis

* Probably it was the Salmo Lemanus, or the great trout of Genera. The following are also found in the lake:-Salmo umbla or alpinus, lombre chevalier or charr; S. thymallus, the grayling; S. murænula or vendace; S. Wartmanni, the lararet; S. punctatus, Coregonus fera or gwyniad; and C. hyemalis.

$\uparrow$ Paradisia liliastrum and species of Phalangium, Ornithogalum pyrenaicum, Androsace villosa, the Sea-buckthorn, the Dog-tooth Violet, the Cyclamen, Cucubalus bacciferus, Sorbus domestica, Saxifraga hirculus, Crocus rernus, and Lilium martagon are found around Geneva.licuter Cat. 
religiosu extends thus far northwards. Mr. Bakewell studied a very curious feature in the district, which must strike everybody who leaves the beaten trackthe immense blocks of stone, erratic or scattered over the surface, and was one of the first to attribute them to glacial action in one form or other.*

Adieu, Geneva city! and lake especially! we will think of you hereafter, and read Byron and Rousseau. Here is the land the loss of which the last deplored in his exile, execrating almost that which gave him refuge. We had set out from the very spot nearly which he thought so drear and inhospitable, and now begin to think of it. Happy the feeling one has for one's natal spot and home; some have nostalgia who are not Swiss! We must not forget to thank Geneva for her many labourers in science-the Jurines, the Hubers, Trembley, Saussure, Pictet, Prevost, Bonnet, Vaucher, and Deluc. She has, too, been the retreat of many of the unfortunate and persecuted of this world. On Monday morning we again made acquaintance with the diligence, taking a rotonde and banquette place, in the double view of economy and of changing now and then. The first we found to be the worst, though the open air was piercing at night, late in September. Looking back from the Jura was a splendid panorama of the western Alps. We had occasionally to walk up the hills, and thus got a glimpse of the Jurassic flora; but roadside botany is always unsatisfactory, especially when we travel by diligence or coach, much more by rail, though a

* M. Chatin found the following orchids in Savoy :-Corallorhiza innata, Ceplalanthera rubra, Herminium monorchis, Goodyera repens, and Listera cordata. The most interesting ferns mentioned by him are Asplenium Halleri, Asplenium septentrionale, Woodsia hyperborea, and Polypodium Rhæticum. 
botanist once told me that he discovered a clump of Splachnum as he was whirled over Chat Moss; upon cross-questioning, however, he did not seem sure that the same was not a stray cabbage or something of the sort. Our traps were overhauled at the first French station, and were declared by the searchers to contain no valuables. Nevertheless, we must confess to one or two jewels, or rather trinkets, which we had in our palins, but which escaped detection, and for which deed all the excuse we can make is that they were intended for gages d'amour -for one's sisters. We went on to Paris through Dol and Dijon, and on approaching the capital it was necessary to hold a serious conference as to where we should put up. If we took lodgings we might be starved before we could raise the wind; on the other hand, we were sorry figures for an hotel, though Englishmen pass muster everywhere. We determined to the hotel to go, and to a first-rate one, which we did, and in spite of appearances were received with proper consideration, and feasted at Madame's table d'hôte till we got supplies to pay our bill, moderate enough, after all our fears. Returning home, we this time landed at Dover, and passed through Canterbury on our way to London; it, however, happened to be midnight when the coach got to that archiepiscopal city to supper, so that we can hardly be expected to describe it. 


\section{CHAPTER IX.}

\section{ACROSS THE CHANNEL AGAIN.}

A VERY long interval allowed from the end of the last journey to the beginning of this holiday trip of three. weeks, and we are again in the steamer, making its exit about midnight from Southampton Water (May 19). No flowery anticipations, vague hopes, or youthful emotions! We will not extend our journey further than Normandy; but there at any rate we will see what we can, and enjoy what we may, and also seek to profit from the comparison of ourselves with our near neiglibours.

There remain but one or two of the passengers on deck, though the night is wondrous calm. Probably travelling is less a novelty to the generality of them than to me. There is the same planet in the southsouth-west, Jupiter, which was so beautiful at home. I venture to address one of the crew, faltering from a fear of exposing my nautical ignorance, and he condescends to answer my enquiries. He observes we are having a very fine night, and tells me the names of several lights which are our guides, Calshot, the Nabs, and others ; those are at Ryde, those to the left about Portsmouth. Glancing below, one sees the white foam dashing from the paddle-wheels, and it is more or less fringed by the evanescent sparks of luminous creatures. At daylight there is no appearance of the French coast, but there soon will be. The sun rises crimson from a thick smoky- 
looking stratum of the air, and soon brilliantly lights up the sea; and now the foreign shore is visible enough, a long level high ridge of chalk hills, extending from Fécamp, and beyond it, to Havre, whither we are bound. Though many miles off, we can see the houses at the former place, from the reflection of the bright rays of the sun from them, more brilliant than the surface of the water, bathed though it is in the morning light. As we approach Havre, its two lighthouses and the Eglise de Notre Dame des Flots, as well as a white obelisk to the memory of Count Desnouettes, are seen on the high ground to the left, whilst on the right is the embouchure of the Seine. The chalk strata are all along parallel and horizontal, marked by the rows of flints, but they are not so white as the cliffs of Albion. We landed, and our luggage had to be hauled up on to the pier by rope, that of the ladies of course being uncorded, and fastened with bad locks, and therefore flying open in the process, and exposing the paraphernalia within to the light of the morning sun. The first sounds which saluted our ears (for the French are not now such duns as they formerly were) were the screams of parrots on sale on the quays, some of which seemed to study the French language more thau some Englishmen. There were monkeys too, and a large cage of marmosets.

One of my first visits at Havre was to the Museum. In front stand two statues of Havre men, St. Pierre and Delavigne. On the basement story were statuary, paintings, and antiquities. The paintings included views of towns and ports in France and Algeria, some presented by the Emperor; and also other pictures of local interest or by local artists by Poussin, for instance, a Norman by birth. The 
antiquities included tombs, crosses, and such objects from ancient Norman localities. Above are the galleries of natural history, that to the right named after the celebrated Abbé Dicquemare, that to the left after Le Sueur. The natural objects, with the exception of some remains of Plesiosauri, and other fossils from the formations of the neighbourhood, were rather general and systematic than representative of the district; perhaps in a seaport like Havre this is advisable. There was a large specimen of 'Neptune's Cup,' and a well-preserved and large Octopus vulgaris from the Normandy coast. The collection was open on Sundays, and such was the day of my visit, though I would not advocate the opening of museums on this day, but only botanic gardens, parks, and so on, where all is the work of the Creator, and where health is to be obtained. But a hint nevertheless may be taken from the French. Wishing to see a catalogue, I took up a book placed by the side of the keeper, which I found to be his Prayer Book. He had been to an early service; and many of the people may on the Sabbath morning be seen coming back from church at an early hour.

The town is well supplied with water, which is occasionally made to flood the streets. The people are prosperous, and the children apparently well fed and clothed, and also kept clean. The working classes get good wages, but are not considered sober. But probably Liverpool will not shine when compared with the Liverpool of France in any of these respects. At the Hôtel Dieu a young surgeon showed us round. There was an epidemic of bad small-pox at this time in Havre and also in Rouen. Such patients were not kept in separate wards, though in other respects the inmates are classified; many children and infants are 
admitted. We could not help wondering whether French children miss their parents as much as in England, or parents their children. The elder children were kept employed if convalescent. The beds were beautiful, and the wards very clean and airy, though many of them are more crowded than they should be, and many were old and low, but they had commonly windows on each side at Havre, and in Normandy generally. There was an abundance of religious ornaments in the wards, alturs, and so on; and we noticed the picture of the Virgin with the children of Salette, and the noted inscription. The civilians and militaires were kept distinct. Conservative surgery did not seem in favour; the diet was reported too poor, and it appeared that the medical officer's have not full power in this respect. I was asked what I thought of their system of nursing, but observed that it was scarcely a fair question to be put to a Protestant. 'No doubt the Sœurs liad a great desire to do good.' Their great desire to do good was assented to, but the young doctor said that they were a thorn in his side, and masters over him at least. Here the sisters were at dinner, but at Rouen the ladysuperior was gentle, ladylike, and at the same time commanding. The lunacy department was an open court surrounded by cells with grated doors, and the less said about it the better, except that the patients are not kept there long, being removed to much better quarters at Rouen. The French hospitals are remarkable for their excellent bedding, good nursing, and strict order and cleanliness; smoking is not always interdicted even in the wards.

The gardens of the Hôtel de Ville are rather fine, and there is a flower market held in a square under the trees, which constitute so great an ornament to 
French towns. Another market of lumber of all sorts was also held in a similar situation. The principal church, situated near the provision and fish market, is of the classical style outside, within gorgeous enough. There is a well-appointed Pharos at the entrance to the harbour, where the sailor may learn everything relating to the weather at different places, and other things that concern him.

In the fish market were the monk-fish, the spotted and common dog-fish, the garpike, and heaps of launces of both species. It is indebted to the English. coasts for some of its best fish-for the best of the cod tribe, as the common cod, ling, and hake; their turbot and soles are not large, but the skate is of several sorts and fine. The herring does not bless the French coast with its visits as it does ours. The alice-shad sometimes comes to market. The basse and the great weever, the maigre, the red mullet, the black bream, the scad and the dory also appear there, with other more common fish. The hippocampus has been found on the Normandy coast. The blue shark and the porbeagle, the sun-fish, the smooth serranus, the armed bullhead, and the gemmeous dragonet are found; the sardine (Clupea Sardine) is taken on the coast of Brittany.

I walked to the lighthouse. The church near was a votive one; offerings of various kinds, from a candle to the nodel of a ship, were to be had at a shop hard by. Numerous insects were flying about, especially Melalonthidæ; the common cockchafer in great quantities, so plentiful that I felt inclined to collect them for dissection; but then I recollected that, thirty years before, Straus-Durckheim had already spent a year or tro in exploring its structure; enough time perhaps for one insect. Thousands which had flown 
out to sea were being washed up on the shore. There was also Phyllopertha horticola and Rhisotrogus solstitialis sometimes picked from the flowers in Normandy to feed ducks, also Coccinella (C. punctata) and others. The din of the field crickets was incessant. Descending the cliffs, one may sit amongst the débris forming the undercliff, and think of Bernardin de St. Pierre in lis own favourite haunt, or if we prefer it, fancy Paul and Virginie. Beta, Salvia, and Helminthia, with several of the blue butterflies, and the burnet-moth, were the most noticeable objects. There were some square pools along the shore, no doubt oyster-parks, where the oysters are educated for the Paris market; but at the time in question there appeared to be no oysters in them. The villas between the challk hills and the town are very picturesque and pleasant, the vegetation very luxuriant, particularly species of cornus, ilex, arbutus, and the red horse-chestnut. There was a luxuriant hedge of Halimus. We took another walk to the forest of Montgean, a mile or two off; the walks are open and free-in fact, it is unenclosed. Many other interesting plants are to be found at or around Havre-for instance, by the roadside some unusual species of Atriplex, and labiate and umbelliferous plants. The fig seems almost wild, and there occurs a little puzzling plant, Vincetoxicum officinale. The forest seems less yielding, but many maritime plants occur, as Ruppia, Hippophae, and the Sea-dock, Rumex maritimus, with marsh plants, Zannichellia Scirpi, pond-weeds, and willows, many of them rare. Honfleur and Harfleur are good spots for the botanist. At Trouville, Bupleurum aristatum and tenuissimum occur.*

* Flore de la Normandie, par A. de Brebisson, 1859. 
Left Havre by rail to Bouzeville, through a rich valley, the surface of which was worked into high garden-plots with wet ditches between then, producing vegetables of many sorts, gourds, articholes, cardoons, \&c. The silky white Willow was luxuriant in the damper places, and the Acacia in full flower on the dry banks. The ridges of the houses were covered with Irises, probably I. Germanica and pumila - the fleurs-de-lis we opined, right or wrong. There was some rough common land covered with loose flints, but the country generally surpassed England in richness. The railway banks were gay with blue Milkwort and pink Saintfoin. The bloody-flowered Clover-in some cases, however, with light yellowish flowers-looked very gorgeous, and the cattle were tethered in rows to eat, by measure, it and the Saintfoin. A flock of sheep might be seen feeding close to a piece of wheat or oats, only kept away from it by the sagacity of the shepherd's dog, which constantly galloped round the flock; the shepherd being commonly protected from the sun or weather in a little straw hut, or sometimes in a box on wheels. Near the station I walled to one of the Norman farms, so different from ours in England. One sees, in the distance, a lengthened quadrangular wood or grove, and going up to it there is the homestead surrounded by a high bank-perhaps taller than a man-on which elms or other forest trees are very thickly planited, making a capital fence, and giving shade and shelter within. Looking in from the entrance gate on one side, are seen the farm-house, granaries, orchard, garden, duck- or rather frogpond, and all the other belonging's of a farm-house. I suppose the frogs in the ponds were of the green or eatable kind; at any rate, their croaks were un- 
English. France has more reptiles generally than England-more species of toads as well as of frogs. There are also sereral species of snake, and the French peasants sometimes eat the common sort. The roads were capital, and along one of them two handsome young females, of fine dimensions and high colour, were trudging. They had enormous hats, nankeen jackets, dark petticoats, red cravats or neckerchiefs, and wooden shoes. We afterwards saw no other damsels so attired. In the uplands of Normandy there is little or no grass-land, but there are some rich meadows along the rivers. There is not commonly the same prevalence of irregular and free lines in the woods as we see in England, but an angular mode of planting has prevailed. Both styles have their charms.

We had taken a branch line to Fécamp. The valleys traversed by the rails, as we approached it, were magnificent with the Broom, more loaded with blossoms than we had ever seen before. The town, with its harbours, fills a deep valley between the chalky hills, and is watered by a rapid and clear stream, and of the trout from it we partook several times. The hill to the right was gay with flowery Gorse, which lined its hollows; its escarpment over the sea was clear white, and there were some perforated rocks at its base. I climbed to the Pharos upon it, and to the half-ruined chapel, which, like that near Havre, is frequented principally by seafaring people. This last was a dreary building, with other ruinous walls and mounds about it, and full of votive offerings, generally of little value. I had to take refuge there during a violent thunderstorm, with two or three mendicants also refugees from the tempest-curious characters, apparently a 
mixture of the beggar and religious devotee. However, they asked for nothing, although ready to receive alms. Begging seems now absolutely forbidden in the towns of Normandy, a few cripples only having a badge which entitles them to solicit. In the chapel iron gates kept lookers-on at a distance from the sanctuary. The cliffs seemed to extend eastwards with a level top for many miles, with here and there pyramids of white chalk rising up and breaking the margin's uniformity, on which gulls and other sea-birds were perched. The Cineraria was very ornamental on the short turf about these peaks, looking like handsome Cowslips at a little distance. Below, the beach was generally inaccessible, and strewn with fallen masses of chalk; altogether the place was lonely and wild. The rocks on the Havre side were of a similar character, but presented here and there ingress from the shore to the land by little valleys. I walked on these cliffs early one morning; the slopes were gay with purple Orchises, and I came across a colony of enormous Mushrooms, not Agaricus campestris, but rather, it appeared, $A$. Georgii; three were brought home, and one done for breakfast, contrary to the protestations of Madame our hostess, who insisted upon it that they were not right, and would take them to the pharmacien. With some slight misgivings of my botanical knowledge, I stood firm, and myself and the ladies partook; for a few hours I trembled, lest they should take fright and be ill, and that I had been too presumptuous, but my science triumphed. A party was formed to go and fetch in the whole flock, and Madame herself forgot her scruples, and feasted herself and her whole household on them. Further on was a little village in a valley opening seawards; and still further, about 
balf-way between Fécamp and Havre, Etretat, a small watering-place, having cavernous and perforated rocks, consequently much frequented by artists and lovers of the picturesque. One great arch is visible from Fécamp, the declining sun occasionally shining through it. The French do not appear to frequent the coast, except for the late summer and autumnal months; then only the bathing establishments are open. These are large, handsome, and with all the appliances for gaiety - pavilions, ball and concertrooms, little theatres, shooting-galleries, readingrooms, and so on. An earth fort defends the mouth of the valley at Fécamp, but improvements of a defensive nature are going on here, as at Havre. There was a strange sort of market-place, apparently built on the ruins of some more ancient structure, to judge by the fragments of walls, and full of wretched little shops. The front of the neighbouring church of St. Etienne was of fine Gothic architecture-at least what remained of it; but at this time we had seen none of the other beautiful churches of Normandy. One picture within represents St. Martin giving his cloak to a poor man. As the man is represented with a peg-leg (chirurgery evidently triumphed in those days in France as now), and as the saint is on horseback, one could not help enquiring why he did not rather give him his horse. The cathedral or abbey church is in a better situation, noble in proportions, and extremely gorgeous within, having much carved work, many pictures, and some recumbent effigies. It is dedicated to the Trinity. The abbey itself had princely privileges accorded it by the Pope and by the ancient Dukes of Normandy, and the bones of several of the latter rest beneath its parements. Many of its mitred abbots, too, were distinguished for 
their learning, piety, or magnanimity. The warrior Casimir, ex-King of Poland, was one of them (1668); the celebrated Cardinal Lorraine another. Nonresidence must have been common here, for the abbots were often endowed with other and higher offices in Church and State. Amongst other treasures of the church is that of the 'précieux sang de N.S.,' preserved by a priest over the troubles of the Revolution, and now restored. The abbey also possessed a bone of the arm of St. Blaise, a parcel of the true cross, and some milk of the Holy Virgin.* Many thousand persons sometimes have made pilgrimage to the first-named relic. We heard a strange and superstitious history of it, but it was added that, to prevent any danger of idolatry, the consecrated host is kept with it. We were also told that the footsteps of the Virgin are to be seen in the east cliff, near the chapel above mentioned, dedicated to her. Mary's altars were everywhere adorned with a profusion of beautiful flowers, May being the 'mois de Marie.' In the square before the abbey was burnt, tradition says, by Henry II., the Chateleine des Hogues, no model of her sex for propriety and benignity. There are remains of her château between Fécamp and Etretat. At Valmont, too, about ten lilomètres from Fécamp, was another abbey, almost as celebrated as Fécamp. It had also its castle, possessed by the D'Estoutevilles; and there is a Gallo-Roman camp (le Catelier) on the summit of a hill to the north of the place. The abbey church still remains. In the square before the church, at Fécamp, I noticed, inscribed over a tradesman's shop, 'Marchand d'Antiquités.' 'What a chance for me!

* Rech. Hist. sur Fécamp, par Mad. Busserolle. 
What an interesting shop it must be in this ancient town!' We entered; but, alas! the antiquities were only worn-out clothes and second-hand furniture.

The country around is very pleasant, and diversified with hills and forests, or rather large thickets. Coleseed is grown in great quantities, from which the colza oil is expressed; there are also fields of flax. One place near is called Les Epiniers, and another the Bois de Canada-good spots for herborising, and where we had two or three long rambles. Common plants were Veronica hybrida, Solomon's Seal (Convallaria), Campion (Phyteuma spicata), Spurge-laurel (Daphne laureola), the leerb Paris, the Fly Ophrys, also Orchis conopsea, $O$. viridis, and $O$. pyramidalis. Here, too, were collected specimens of Helix pomatia and the large red Arion, both of which were reserved for England, and the former afterwards bred in a Wardian case. Another day the Ophrys apifera, just out (May 27), was found on the hills nearer the town. The chiff-chaff and garden warbler were vociferous, the latter making sweet music; the willow warbler did not seem so common, but the Dartford warbler is said to be frequent. The insects which we caught were not very remarkable.*

On the flints thrown up from the deep sea were numerous species of Acmæa, looking like pretty limpets, but having the respiratory cavity over the neck. Beautiful specimens of azure-banded Patella were lodged in little depressions along the stalks of the Laminariæ; the depressions are no doubt formed by

* They were Arctia rillica, Anthocera Lonicrræ, Rumia cratægata, Chrysomela polita, Timarchia communis, Phyllobius pyri, Elater æneus, Plusia gamma, Alcis repandaria, Stiganolophia duplicata, and a few others. 
the animal eating the substance away.* There is much fine detritus amongst the rocks, dirty to meddle with, but frequented by many of the annelides. The little long-armed porcelain crab abounded under the stones, somewhat different from Mr. Yarrell's description, the carpus having several short processes in front. Crabs of all sorts are collected for eating, as the larbour, the velvet, and the variegated swimming crabs. $\dagger$ The mussels, though smaller than in England, are also industriously collected, but the French do not eat Actiniæ, though it was on this coast that the Abbé Dicquemare studied them so carefully, and recommended them for food. There was abundance of $A$. crassicornis to tempt the gourmand. The seaweeds and corallines abounded in minute shells. There were some little pedicellate balls of yellowish green jelly attached to the weeds, from which, on being placed in sea-water, little oval bodies escaped, swimming vividly about by means of a circle of cilia around the middle, and having apparently two eyes in front. There were also little globules of a firmer jelly, sessile on the fuci, containing, certainly in this case, ova of mollusca. Were the first the ova of Trochus, and the latter of Littorina? Turbo littoreus deposits its ova singly on sea-weed, each egg somewhat of the shape of a rounded cap with a rim, diaphanous externally, and the yolk opaque. In the

* Molluses found on the coast are Onchidium Colticum, Tritonia Hombergii, T. arborescens, Aplysia occidens, Doris lacris, and Eolis papillosa; also Pleurobranchus sigaretus, Calyptroa, Fissurella, and Phasianella. Wo saw no traces of Haliotis at Fécamp.

+ The following Crustacea are giren by Messrs. Audouin and Edwards as found on tho Norman coast:-Cullianassi subterranea, Axius, Stirynchus, Thia polita, Pirimcla denticulata, Nebalia Geoffroyi, Athamas nitescens, Hippolyte, Galathere. They also found Clavelina and Siphunculi. 
harbour we gathered a harvest of diatoms, $A c h$ nanthes longipes, and others.

After a week's stay at Fécanip, we left for Rouen, passing through Yvetot, a pretty place. The rails traverse a succession of wooded hills and fertile valleys, the latter running down to the vale of the Seine, and diversified with houses and with mills, scattered here and there, which add to the cheerfulness of the views. At the last station before arriving at Rouen, Maromme, we stopped for the greater part of a day and rambled to some chally hills and chalk pits, and through some extensive woods, the outliers of one of those great forests (Roumare) which in this part of France occupy the peninsula-like tracts formed by the windings of the Seine. The ground under the trees was entirely covered with the lesser periwinkle. There were some rose trees in the villages, bearing yellow flowers, more beautiful than any I had noticed elsewhere. The grassy hillocks abounded with several rare orchids, amongst others Orchis odoratissima. At a farm-house we noticed an image or shrine of the Virgin in the court, apparently of considerable antiquity. On the front of a house at Maromme was inscribed 'Pelissier aimable Jean Jacques, Maréchal de France, est né dans cette maison, le 6 Novembre, 1794.' The country is very fertile, equal to the finest parts of England, the mills and factories, scattered along the streams, constituting no doubt the source of the prosperity which the people evidently enjoy. A yeoman of Normandy and of England could scarcely be distinguished by their looks.

Of Rouen, with its majestic river, its bridges, islands, and cliffs, its churches and antiquities, what is to be said by us, when so much has been said by 
more competent persons? I walked eastwards along. the river and mounted the clallky hills in this direction, coming at length, and it was Sunday, to the church of Our Lady of Bon Secour, modern, but a notable object from its beautiful architecture and elevated situation, as seen from Rouen. Many carriages awaited the termination of the services, and in front there was a sort of fair for all kinds of religious and votive trinkets; there were candles at from a franc to two napoleons each. I had passed, by the side of the road in the valley, the ancient church of St. Paul, built, it is said, on the site of a heathen temple of Venus. Coming back over the Côte St. Catherine were mounds and some remains of buildings on the high ground, amongst others, of the castle destroyed A.D. 1590, the place where Prince Arthur was murdered. In the walk I picked the pale Toadflax (Linaria repens), the Larkspur (Delphinium), and Motherwort (Leonurus cardiaca).* The Hospital lies on this side the city at the foot of the hill; the situation is low, but the grounds are pleasant for the patients, and the whole establishment presents much to admire. The Botanic Garden, situated on the left bank of the river, is not large, nor the hothouses and greenhouses equal to many in England. There were the Adansonia, Strelitzia, Chamerops, Cacti, Pandanus, Plantain, Sugar-cane, Papyrus, and Dracæna, and fine orange trees in full bloom in tubs. In the Museum of Natural History were many objects to interest. Of shells there was a large collection, especially, as was the case at Havre,

* Rouen and its environs are rich in rare plants ; the following occur: - Isuardia palustris, Enanthe Luchenalii, Bupleurum falcatum, Xanthium strumarium, Actæa spicata, Lobelia urens, Villarsia nymphroides, Digitalis lutea, Herminium monorchis, Globularia rulgaris. 
of some genera, as of Unio and Anodon. We noticed U. subtetragonus and obtusus from the Seine, Haliotis lamellosa from Toulon, also $H$. communis from the French coast. The Neritina fluviatilis from the Seine is much handsomer than its English representative. There were also $N$. lacustris and Dreissena polymorpha from the Lower Seine; the skeleton of a whale, and fossil shells from the Côte St. Catherine, amongst other's Ammonites Rhotomagensis, so named from the Latin name of the city. The stuffed birds generally were fine, and there was a very interesting collection of their nests - the thorny and forbidding one of the magpie, and many very wonderful ones made by foreign birds. Phrenology seems not quite defunct in France, as here are retained its illustrations, with skulls of the Merovingian French.

Many of the pictures in the gallery of paintings are very large, and we fancied fine and well worth inspection-ancient and modern; many no doubt originally from churches and convents, some by Poussin, Gericault, Jouvenet, and other Norman painters. The library at the Hôtel de Ville originated in a collection made by the heads of the reformed church, Basnage, Le Gendre, and De Langle. At the breaking up of their college, in 1685, it came into the possession of the Jesuits; but they in their turn were made to give it up, and it is now domiciled here, with valuable additions of books, missals, and manuscripts, some of them of great local interest. The departmental Museum of Antiquities occupies the cloisters and dependencies of the suppressed convent of St. Marie. It contains many remains of old Rouen-of its houses and churches; Roman antiquities from the baths and theatre of Lillebonne,- - the Juliabona of Romano-Gallic days, amongst other things a statue 
of Faustina in marble, and statuettes in bronze; also a large mosaic, representing Apollo playing on the lyre, discovered in the forest of Brotonne, and partially restored. There are likewise interesting Celtic instruments in flint and stone from the Somme, bronze implements and Merovingian ornaments, funereal urns and Samian pottery, exquisite glass from ancient churches, as from those of St. Eloi and Notre Sauveur, coins, charters, and manuscripts, one of the latter with the Conqueror's signature, a cross, and ancient tiles and pottery of Rouen manufacture. There is, moreover, a crystal box with some powder of the heart of Richard Cour-de-Lion, and a cup of metallic antimony to be filled with wine, the draught, after standing in it, becoming an emetic. A valuable characteristic of the museum appears to be the preservation of works of Gothic art, belonging to buildings which have been pulled down during the last few years in the improvements of the city. There is also some fine Palissy, Majolica, and Della Robbia ware. There are other private collections in Rouen.

St. Ouen strikes every beholder as a queen amongst churches, and the neighbouring Hôtel de Ville and adjoining gardens complete the interest of the locality: the Hôtel de Ville is, however, but a plain building, at any rate when compared with the beautiful Palais de Justice, a remarkable application of florid Gothic to civic purposes. In the gardens, but attached to the church, is an ancient Norman tower, Tour aux Cleres. The pillars within St. Ouen's must have been cut from rocks of the cretaceous formation, for they have flints imbedded in them, but their carved edges remain beautifully sharp, and the flints are cut or ground down perfectly flat and smooth. To say nothing of the interior, many parts of the church are 
considered beautiful by the connoisseurs, especially the rich front, the celebrated north and south rose windows, the central lanterned tower, and the south portal. The following is a description of our James II., as he worshipped in this church after his abdication, from the account of a monk in the city library: -'We noticed that the king heard mass with exemplary devotion, reading from time to time in a book of prayers, which appeared well worn. He used spectacles to read with. He never turned his head to one side or the other, but he cast his eyes sometimes upon the altar with much humility. His dress was very simple, of white grey, and the pockets of his close coat were extremely filled out. His shoes were flat, of common leather, and he appeared to have lost the heel of the left foot; his hat was black, with a golden cord which seemed old.'

The Cathedral is more dilapidated than St. Ouen's, being mutilated at the front for instance, but is rich in the extreme in its portals, rose window, panellings, and side towers. Moreover, the Cathedral is very interesting in its interior for its memorials of olden times. The base of the left front tower is comparatively rude, belonging to a more ancient church, dedicated in the presence of the Conqueror. The portail des Libraires and the portail de la Calande are very rich and correct in their sculptures. All the side chapels have subjects of interest in paintings, sculpture, stained glass, or tombs. The tomb of Rollo is in one of the chapels; other tombs are those of the Cardinals d'Amboise, an effigy of Richard Cœur-deLion, and a tomb of the husband of Diana of Poitiers, the latter having inscribed upon it, ' $\mathrm{Oh}$, Louis de Brézé, Diane de Poitiers, thy desolate widow, has raised this tomb to thee. As she has been inseparable 
in thy bed, and thy very faithful spouse, she will be the same in thy sepulchre.' Alas! she kept not her vows, as lisistory relates. The irou spire of the cathedral is its only arcinitectural eyesore. On the Saturday evening we attended a service here; some children chanted a very long hymn to the Virgin, of simple melody, occasionally pausing whilst some portion of the service was carried on. During the hymn, too, the altar of the Virgin was being lit up with its hundreds of tapers, the effect being entrancing. I sought out several other churches, all interesting; St. Eloi's, for instance, situated in a low part of the city, interesting at least as to its exterior, as was St. Maclou's, having a fine side door to the north, and five canopied portals in front; and not very far from this last was St. Vivien's, with a rich Gothic porch. The church of St. Gervais is the remnant of a monastic building, though it is said to have some traces of Roman work. In the crypt the Conqueror died, after his injury at Mantes, to be afterwards buried at Caen in his own cathedral, but not without a citizen disputing his right to his grave by crying haro! or justice! over it.

There are several other churches in Rouen, as those of St. Romain, St. Patrice, and St. Vincent, celebrated for their painted windows; beautiful, curious, or very ancient. At St. Patrice is the picture of a saint making a thief, who has stolen a sheep, bleat against his will, and at St. Vincent is one representing the mule adoring the host. St. Lô and St. Godard are two churches near the middle of the city; that of St. Julien is an ancient conventual building at Petit Quevilly. St. Etienne's is at the corner of the Rue des Iroquois. Several others have been levelled or are desecrated. We stumbled on 
a very beautiful one, now a workshop or carriagehouse, dedicated, we believe, to St. Laurent. There are towers, minus their churches, as that of St. André, conspicuous in the new Rue de l'Impératrice; and near it are La Grosse Horloge and an adjoining belfry, which catch the eye of every stranger. Other similar objects, sculptures, fountains, and ancient houses or hotels, are of frequent occurrence. The statue of Joan of Arc is a sorry affair. A tower of the castle of Philip Augustus, where she was inprisoned, is still standing. She was burnt in the square or place where the statue is now seen. The remarkable ancient Hôtel de Bourg-Theroulde is close by. Corneille and Boieldieu have their statues as natives of the place.

The remarkable windings of the Seine from Rouen to Havre make the journey by steamer very long; the boat only begins to run in June, and we were a little too early. We must therefore borrow for a short account of the trip. The beauty of the river makes amends for its length. In its bends it encloses portions of high land covered with vast forests, in which no doubt the Norman dukes followed their pastime of hunting. The interesting objects passed in the voyage are Moulineaux and the château of Robert le Diable; Bouille, to which place there are frequent boats from Havre; the quarries and grotto of Caumont; the abbeys of St. George de Boscherville and of Jumièges, the latter once renowned for its privileges, riches, and learning; La Meilleraye, the ruins of Caudebec, and the abbey of St. Wandrille; the village of Caudebec, too, having a very beautiful church; the château of Tancarville and Quillebœuf, the two last on the opposite sides of the river. Between Caudebec and the last places occurs especially 
the phenomenon of the barre, at certain periods of high tides, rendering the navigation difficult and dangerous. Quantities of éperlans or smelts are caught in the lower part of the river above Honfleur, and the sandhills are frequented by rabbits and sheldrakes, a species of duck, breeding in rabbit burrows, and more beautiful in appearance than good for the table, though they are sometimes domesticated. The smelt is, we believe, the true one, Osmerus eperlanus, not the sand-smelt, nor the Cyprinus bipunctatus; this, however, is called the Seine smelt.

At Havre I took the steamer to Caen, my friends preferring to cross over to Trouville, a much-frequented bathing-place, and so on to Caen by rail. We steamed along the Normandy coast, here low, for the chalk cliffs had ceased, and we were passing the sub-cretaceous formations. We entered the mouth of the Orne, a few miles up which river Caen is situated; and now the oolites occurred, rising up westwards. Our boat was necessarily flat-bottomed, as it had to enter the shallow river, and therefore when out at sea it had rolled a good deal. The Orne cannot be entered at low water, and at other times its navigation requires care, as for instance in passing the fellow steamer. The other shipping goes up to Caen, and back to Ousterham, by a canal. The scene at the entrance of the river is dreary enough; small boats are passed carrying shell-sand up to Caen, and others engaged in fishing. The nets are square, and suspended from two crossed bent rods, the whole being raised or lowered by a beam or huge fishing-rod, as it were, attached near the bottom to an upright in the boat; in fact, the precise mode used by the Chinese near Canton. What is caught we did not see, but it must be some small fry. The oolite 
quarries of Ranville are soon passed on the left hand, and the country becomes rich and wooded up to Caen, and near the town the margin of the river is planted and laid out in wallss. The saltness or freshness of the water, as we proceed, is curiously marked by the vegetation-Algæ at the mouth, then Enteromorphæ, and at last Ceratophyllum, \&e.

The cretaceous strata of Normandy, inclusive of the Chalk Marl, Upper Greensand, and Gault, furnish the characteristic fossils of those formations at Ronen, Havre, Douvres, Dives, \&c.-Ammonites Rhotomagensis, $A$. Gentoni, and others; Hamites and Scaphites; Nautilus pseudo-pompilius, N. elegans, and N. simplex; Cucullæa, Trigonia, Catillus, Ostreæ, Plagiostoma, Pectens, 'Terebratulæ; also Ananchites, Nucleolites, Galerites, and Cidarites; and at Dourres, Pentagonaster, and Pentacrinites. The Lower Greensand occurs at Havre and Rouen, with characteristic shells - Inoceramus, Gryphæa, Trigonia, Turrilites, Cassis, Podopsis, \&c. At Honfleur and Havre the Marne Argileuse Havrienne, analogous to our Kimmeridge Clay, occurs; with gavials, Lacerta longirostris and urevirostris, Ichthyosaurus, and Plesiosaurus, at the first locality; and shells of the still lower Coral Rag and Oxford Clay occur at the latter place. The lowest Oolites and Lias occur more westwards, as at Caen and Bayeux, with reptilian remains and Belemnites, Gryphæa, Ammonites discus, Terebratula digona, \&c. According to Brongniart, Ortloceratites, Conularia, Graptolitas, \&c., occur in the quartzite. It thus appears that the older strata successively crop out or rise to the surface as we proceed westwards, till at length we come to the Silurian strata, non-fossiliferous granite, \&c., of West Normandy.

Quarters secured for a week in a quiet street, our- 
selves the sole possessors of the house, I went in search of the notabilia of Caen. I first came to St. Pierre's church, having: a fine spire, though in general we may say that, as far as the spires alone are concerned, Eingland may boast of many surpassing those of Normandy. The eastern apsidal termination of the church is of late Gothic, or what the French term flamboyant architecture. We attended service here several times; one evening service was very delightful, and high mass on Whitsunday very splendid. Enormous cakes were cut to pieces, and handed round by a beadle, dressed in an extraordinary manner, attended by a benevolent and-venerable-looking priest carrying the treasure bag. We tried to secure a bit or two for some hungry children, but the beadle would not see them, or perhaps he thought no pence would be forthcoming. At St. Julien's, at the feast of Pentecost a dove was formerly let loose, and flowers of seven kinds, as well as inflamed dossils, were dropped from the vault upon the officials. St. Pierre's church was crammed, and all seemed devout. There was but one of the old high Norman head-dresses in the church. Some carving here is ludicrous; there is Aristotle on all fours and bridled, carrying his mistress; Tristan de Léonois passing the sea on his sword in search of his beloved; and Virgil (some say Hippocrates, but this we cannot believe) suspended in a basket from a wall, his proceedings having been none of the most creditable. The sculptures at some of our own ecclesiastical edifices trespass beyond all bounds of propriety; several such are, or have been formerly, attached to Lichfield cathedral. One which we have seen represents Zimri and Cozbi, or two such delinquents, but the executioner is the evil one, and not Plinehas. Ecclesiastics them- 
selves are made to figure in these odd impersonations of sin in some cases. The church became the Temple of Reason at the great Revolution.

I next stumbled upon Old St. Etienne's, though it is more modern in reality than the New St. Etienne's, close by. It appeared to me to be of beautiful and faultless Gothic architecture of the most palmy age ; but, alas! it is now desecrated and full of lumber, and its groined ceiling left to the bats and swallows. At the chancel end, the eastern wall of which is curiously inclined to the bearing of the road, is the headless figure of a man on horseback; the west entrance is richly adorned with an ogee canopy. St. Etienne Neuf is one of the two great abbatial churches, of which this was erected by the Conqueror; and the other, the Church of the S. Trinity, or the Eglise aux Dames, by his queen, Matilda. His cenotaph, or tomb if any bones remain, is at the former church, before the high altar, and there is a portrait of him shown in a side chapel, wonderfully like those of our Henry VIII. The central tower is but a wreck, the side towers and spires very plain but beautiful; altogether the church is a fine specimen of the rather severe Norman-style of the age and province. St. Nicholas's is not far off, but desecrated and ruinous, the basis generally being Norman, with some buttresses which in England were formerly considered Saxon-that is, shallow and wide; but above, the spire and other parts are more ornamental and later, the windows being lancetshaped. The roofs of the component parts of the church are curiously out of the usual order in their relative elevations. The great bell is under a wooden erection on the south side, and close by is a Norman gateway, belonging to some other building once 
standing there. Further on towards the castle is the Church of St. Julien, of rich architecture, decorated windows, and having a saddle-shaped roof to the tower.

The castle must have been a formidable place in the time of William, to judge by the deep trenches and massive walls ; its circumference is of irregular form, enclosing some buildings, rich grass-land, and avenues of trees. There are but two buildings remaining of any pretensions - one mostly of decorated Gothic architecture, and another with Norman zigzag work. The former, nearest the entrance, was a chapel dedicated to St. George, where Henry V. of England held a chapter and created twelve lnnights; the other was the great hall of the castle. The Cluurch of St. Giles is not very far off ; it is generally of fine architecture, but with some additions in bad taste; it seems closed, or about to be. Close to the last is the great church built by Matilda, and now just restored-some say, not pleasingly. The HôtelDieu adjoins it, and a religieuse very good-naturedly showed us the tomb of the queen, the interior of the church, and also of the hospital; in the latter the beds and wards are clean and orderly, and the cooking department is first-rate. The church, like its twin, or rather husband, church, the Conqueror's, presents us with fine, and at the same time more graceful, architecture. It was formerly attached to an abbey of Augustines, also built by Matilda, and her daughter Cecile was one of the first religieuses, leaving the abbey of Fécamp for that of Caen. The church boasted once of possessing the Saracen standard brought from Askelon. Notre Dame, or St. Sauveur's, situated in the Rue Froide-rue, is a curious ancient churcl with a double nave; St. Jean's is also situ- 
ated in one of the principal streets, and has much worth notice within - tiles, pictures, and painted glass. Beza was brought by Coligny to preach in this church, to raise the sinews of war. St. Sauveurdu-Marché is now the coln-market. 'The Protestants have the Church of the Benedictines; the guide-book calls it 'vaste salle, voilà tout.' My friends told me that it was adorned, at the chancel, with paintings of chubby cherubs, amongst smoky clouds. There are several other churches - St. Sepulchre's, St. Michel's aux Vaucelles in a southern suburb, once appertaining to Roger, Bishop of Salisbury, the builder of his own cathedral in England, and near it some remains of another church of St. Paix. There are also St. Ouen's, and the Jesuits' church or Nerv Notre Dame. These are but a portion of the religious buildings which adorned Caen; it, as well as Rouen, underwent strange vicissitudes of fortune from the struggles of the French and English for dominion in Normandy. After being virtually lost to the latter, it was twice retaken by them, under Edward III. and Henry V. Like Rouen, it also suffered much during the wars of the Catholics and Huguenots.

The Museum of Natural History is hardly kept up in good condition, though it contains much to interest. Here are the botanical collection of D'Urville, and the zoophytes of Lamouroux. We noticed Testacella haliotoides, from the gardens at Caen; Helix pomatia, Calvados; H. limbata, Caen; Anodonta complanata, Caen; Unio margaritifera, dep. La Manche; $U$. littoralis, Caen; smaller than the last, and much eroded; we ourselves picked it up, as well as $U$. Batavus. U. Moquinensis, and U. Regguerii, are also in the collection obtained from Caen; Haliotis tubercularis, from the French coast. Amongst the pre- 
served fish there were Lampris guttatus; Leuciscus mutilus, vulgaris, and dobula; Labras bergylta, Orthagoriscus mola, Petromyzon maximus, Raia rubra and undulata, Myliobates Aquila, Torpedo marmorata, and Squatina, all from the neighbouring sea or river. The fish market was well supplied; we noticed that the little Donax complanata was sold in large quantities for eating: it is collected on the sandy coast. Venus pullastra and other species, and Mactra solida and glanca are also eaten, as well as the insignificant Palcemon squilla. To retur'u to the Museum: there were fossil bivalves, corals, and sponges from Ranville, a place mentioned above, as well as from the coral rag of Trouville; Trigonia and other shells from the Kimmeridge clay of Havre and Honfleur; Asteracanthus, from Le Hève, near Havre; teeth of mastodon and elephant from late deposits; and from the Caen quarries remarkable jaws and other parts of Teleosaurus, also portions of Megalosaurus and Pekilopleura.

The Botanic Garden is small, but compact and picturesque, with a striking group of sculpture enclosed by firs and other coniferous trees. Few of the most interesting trees had names attached; there were Inga anomala, bananas with immense bunches of fruit, fine orange trees, Cape jasmines, and oleanders, all full of bloom. On the castle walls we picked Valerianella coronata; Eruca sativa, Gypsophila muralis and vaccaria, and Phyíeuma orbicularis are also found on walls and in quarries about the town.

Though there are not many first-class pictures in the public gallery, yet several of them are interesting; for instance, a beautifu] one by Perugini, a portrait of Charlotte Corday, who lived at Caen, a Descent from the Cross, by Tintoret, and a St. Sebastian. 
This and other provincial collections were founded by the museums of the metropolis being required to disperse in the provinces their supernumerary works of art: when will England be as wise--as just? Few towns of its size, and none in England except Oxford and Cambridge, can rival Caen in its scientific, religious, and educational institutions. Its press has been by no means contemptible. Its churches, several of them exquisite in their architecture, though they do not rival our cathedrals in size, are great objects of interest. The meadows and walks along the river-side are pleasant, and offer miles of walks with shade by day, and the song of the nightingale at night. From these walks the town is seen to stretch west and east, with William's and Matilda's sacred fanes at each extremity. I visited, in the neighbourhood of the town, a hospital for aged paupers. The building and gardens were good, and the inmates appear to be well nursed by sisters. The beds were, as usual, excellent, of considerable depth, and with white sheeting, the walls of the wards plastered and adorned with pictures; the clothing was good, and not made distinctive to the inmates; tobacco was allowed, with cider for ordinary drink, or wine if sick; the cuisine was laudable. There was no doctor to the establishment, though populous; the inmates are preserved from the doctor by means of the cook. There was another hospital of the same class which we did not see, and another still, but of a superior kind, Bon Sauveur, a vast establishment, having a department for insane patients, another for the deaf and dumb, an infirmary, schools, nursery, \&c. In the last hospital Brummel ended his days; he told a fellow-countryman, in a whisper, as insane people often do, that he was 
starved, and had never any dinner; fortunately, his friend had just watched him demolish the greater part of a chicken.

One of my rambles was to the quarries of Allemagne, situated along the river side above Caen. Large tumnels or roads are driven into the stone for a great distance, somewhat slanting to the east, the bedding of the strata rising a little towards the older formations to the west. Caen is surrounded also by open quarries. I found several nautili a foot across, and carried one away home. There were also perfect specimens of Gervillia, and also plates of Teleosaurus, not uncommon. The church of High Allemagne has some Norman work, that of Low Allemagne was just rebuilt in good style. An institution here for Enfans tronvés is beautifully situated, surrounded by noble spruce and other umbrageous trees, the grounds also ornamented with statuary. A mile or so further on, I came down upon the river, and the oolite was unexpectedly replaced by a kind of red quartzose rock, forming cliffs close to the river, the Flora also quite changing with the soil. A. Sedum (S. Fosteri), Cotyledon umbilicus, Linaria repens, and heaths now abounded. The Lizard orchis (O. hircina) grew plentifully on the hedge-banks, very rare in England, not liandsome, but curious : its strong scent proceeds from the long curled lower lip alone. Some of the orchards here looked languishing, and many of the trees were overgrown with mistletoe.

The Caen stone is also raised from pits, particularly at a village called Maladrerie, beyond St. Stephen's cathedral. There is a Calvary on the roadside, with a great crucifix, on the steps of which some females were rather riotous, but, on the other hand, most people, when passing, stopped in their conversation, 
and devoutly crossed themselves. The pits occur in the open fields, and are not marked by much rubbish, but rather by the great upright hauling wheels by the sides of the pits' mouths. Turning to the right, over a few fields, was a great enclosure, surrounded by a high wall, and within were the remains of the once celebrated abbey of Ardaine. With some difficulty, and meeting with the sole bit of incivility which we experienced in polite France, admission was obtained. The beautiful abbey church is now the barn of the farm, its decorated doorways and Catharinewindow unheeded. There was a productive garden in the enclosure, said to yield the finest fruit in the Calvados department. The Eranthis hiemalis is wild here. I noticed on the tops of the walls that an insect had formed tubes of mud and mortar, bent like some chimney-cowls, to protect them from the wet, and about the thickness of a quill; the perfect insect could not be met with, but there were several green caterpillars clustered at the bottom in the soil where the tube sprang from; no doubt collected to form the nidus and food of the artificer's young. Perhaps they were the nests of a wasp-Odynerius. We also took, or saw, the brilliant Carabus auratus, Colias edusa, and Papilio Atalanta.

The railway passes westwards through a fine country by Bretville to Bayeux; we availed ourselves of it, and got out at that old ecclesiastical city. After a stroll through the market, I pushed on to a place called Ryes, and then walked down to the coast near St. Cóme, where a little brook emptied itself into the sea, or rather was choked in a marsh just at its margin. This little river afforded diatoms very pure, including Cymatopleura elliptica, Actinoptychus senarius, Amphora, and sundry others. Orchis incar- 
nata, and Lathyrus aphaca, grew here, with other marsh plants. There was a submarine turbary a little out, and men were digging up the peat for fuel or manure. To the right, along the depressed coast, were the low reefs called Calvados, giving name to the department, and more dangerous to mariners than higher rocks. On the left the coast was bolder, the strata still nearly horizontal, consisting, we think, of the Lower Oolites and Lias. We knocked out a few of the fossils which appeared in the rocks, and then walked along the margin of the sea, it being a low tide, till we came to a little port or village, Arremaches, we believe, apparently an incipient watering-place. The rocks seemed tolerably favourable for the pursuits of the naturalist in animal and regetable forms.* Far out in the distance the Cotentin coast was stretched, appearing not very elevated. Cherbourg is near the extremity of this long peninsula: the rails would have soon taken us to Coutances, St. Malo, and Mount St. Michel on the opposite side of this great promontory. On the hills the beeophrys abounded, and a church landwards had just been rebuilt or restored; we got a French bow from the priest, almost worth walking from Ryes to receive. Grammites Ceterach grew on the walls about the church. The specific name of this fern is Celtic, Ceder y urach; the Welsh dictionary, however, says this properly is the name of an Equisetum.

Many of the churches in the district seemed of Norman origin, and extremely interesting, with low spires or saddle-shaped roofs to the towers. Bayeux itself was held by Odo, the half-brother of the Con-

\footnotetext{
* Amongst the Jattcr, Desmarestia ligulata, Padina pavonia, Gigartina compressa, Lawrencia.
} 
queror. We visited Bayeux cathedral ; it is a good deal like St. Etienne's at Caen, but the buttresses are of Gothic architecture, being deep, not shallow; and the porches would appear to liave been built later, being of florid Gothic. The two front towers are fine with elegant spires, and on one of them is a little cot, perched at an elevation of about 200 feet, which, however, does not look incongruous; was it for hermit, bell-ringer, beacon-lighter, or watcher? The chancel is sunk below the level of the floor of the nave, and several descending steps lead to it. There is a crypt, with several ecclesiastical effigies and tombs, and in one of the sacristies is a remarkable 'armoire' and curious fresco paintings. It being Whitsun eve, I saw a little of the grandeur as well as of the present decay of this once proud temple. Though there were scarcely half-a-dozen worshippers, the service was imposing; the principal performers being four priests in splendid vestments, who walked up and down in the chancel reciting psalms, aided also by choristers, and by the grand notes of the organ. They occasionally stopped and bowed to a superior seated on the north side of the chancel, who returned the salutation. A fat gentleman in an alb gave the note occasionally on a great violoncello. At the entrance of the sanctuary, but outside, sat two men in black robes, whether penitents or door-keepers deponent sayeth not, but, at any rate, they occasionally solaced themselves, during the long service, with a large pinch of snuff, taken with much gusto. One or two other young and good-looking ecclesiastics paced the aisles, and one or two young women at prayers seemed to have their devotions occasionally disturbed by their presence. One of the former once or twice approached, and, seemingly half afraid, addressed us. 
It appeared that he was ready to be employed as cicerone, and he also offered stereoscopic views, which would liave been purchased, but sometimes one's purse may happen to be less furnished for contingencies than usual, and so it was with mine that afternoon. I was too at the moment observing the skull and bones of a saint, and real saints are not met with every day; may our disregard then of the poor priest's offer be overlooked! The bones belonged to St. Eustache, and were placed under an altar in one of the side chapels; the skull seemed high and wide in the cheeks, and somewhat Tartar-like in appearance. He was a Roman soldier under Trajan, but might have been of barbarian birth. Tradition says he was burnt; if these bones belonged to the martyr, he must have met with some other kind of death. We afterwards went to the institution where the celebrated tapestry is to be seen; the descriptions of it are pretty well known, but there were also other interesting antiquities at the same place.

I may say, that here was the end of my holiday trip, though my companions saw somewhat more of the country. Our opinion of the French was not lowered by what we saw of them: they are a great and martial nation, and Normandy is a fine country, ' like the garden of the Lord for goodness.' The workpeople are well off, and I noticed that several of the Normandy women, apparently workers, had each a gold watch, and they were besides very clean in their dress, especially in respect to their caps, which were commonly small in pattern, with a crimped band in front. It must be difficult to enter a railway carriage with some of the head-dresses peculiar to certain districts; they are extraordinary structures. The wornen had not that meretricious fondness for 
gaudy colours that existed in England at the same date. Wooden shoes are often worn, but commonly over light leather ones. Many of the Normandy surnames are the same as ours; their scythes, rakes, forks, and other implements, however, look foreign enough. With respect to the men, they appear generally to endeavour to make the best of themselves, and seem to think their persons not quite so despicable as the English workmen do. They have generally clean linen, at least on feast days. More wretchedness, rags, and dirt may be seen almost anywhere in England than in Normandy - of the rest of France we saw nothing.

The vine is not grown in Normandy, at least in rineyards: cider is the common drink; brandy is distilled from perry, and is bad enough. Flax and hemp are grown occasionally, and tobacco further westwards, also two sorts of Sarrazin or Buckwheat. The butter of the province is the best in France.

The flora of Normandy is rich in Orchider, including several of the rarer forms, as Cephalanthera, Spiranthes, and Liparis; also in the species of many other genera of plants, as Rauunculus, Viola, Rosa, \&c., but perhaps too many species are made in these genera. The province is also rich in Papilionacer, but only two species of Saxifraga are found. Several genera of plants are met with which are not seen in England: some of these may be natives of Southern Europe and only naturalised,* but there is less doubt about other genera. $\dagger^{+}$The following species occur, and are not found across the Channel:

* Gratiola, Lycium ovatum, Physalis alkekengi, Calendula, Hyssopus.

† Phalangium, Trapa, Nayas, Carthamus lanatus, Amaranthus, Lunaria, Biscatella lerigata, \&c. 
Lathroea clandestina, Muscari comosa, Arum Italicum, Anemone hepatica, and Eranthis hiemalis. Many of the rare Cornish plants occur, for inistance, several of the Paronychix; and Erica vagans and ciliaris. Many plants are not uncommon in Normandy, which would be considered rarities in England.*

M. Mocquerys has published an 'Énumération des Insectes Coléoptères' of the Lower Seine, remarkable for the care with which their habitats, and the names of the plants on which they are found, are given. Many rare species are furnished by the forests, marshes, and chalk hills along the Seine-often the wood brought for burning into the town affording interesting species. Procrustes coriaceus, Bromius obscurus, and Hispa atra, rare or not indigenous in Britain, are found. Some species in the list should perhaps be excluded, presenting instances of importation by means of foreign timber, nuts, grain, \&c. $\dagger$ Calosoma sycophanta is very rare with us, but is found in the forests, and even in the boulevards around Rouren. There are many interesting Dytisci, and other aquatic beetles, as Potamophilus acuminatus, found in the Seine, also rare Anistomi. Amongst Scarabæi, Lucanus cervus is common, also Platyceres caraboides and Sinodendron; Dorcas is rarer, Typhous is not common. Cetonia aurata and morio are found on roses, and Oxytheria on the chrysanthemum. The glow-worm is common, with other allied insects. $f$ Cantharis vesicatoria occurs, and Nacerdes melanum

* As Thesium, Aristolochia, Asarum, Aconitum napellus, A. rulgaris, Dentaria, Isatis, Oxalis corniculata, O. stricta, Arnoseris.

$\uparrow$ Plochionus Bonfilsii, Lebia Massiliensis, Trigosita Mauritanica, Silvanus frumenturius, and others.

$\ddagger$ Lygistopterus sanguineus, Omalisi, Phosphænus hemiptorus. 
on the quays at Rouen and Havre. Amongst the Cerambyces, C. cerdo is common, C. heros absent. Aromia moschata is also common.*

* Other rare or interesting insects are Sarrotrium clavicorne, Hetrerus quadratus, Phlreophagus aneopiceus, Coryssomerus capucinus, Cryptocephalus imperialis, Clypeaster lividus, Gryphinus lateralis. 
\$

\section{CHAPTER X.}

NEARER HOME-AT HOME-WINTER EVENINGS.

Most people, in these days of facile travelling, have approached London from the north-west of England; many must have done so in the days of the stagecoach, and then the traveller had more chance of being struck with the change which occurs in the aspect of the country when the chalky Chiltern hills are approached. If the traveller came from the more mountainous and northern parts of the island, he must have necessarily passed through the tame districts formed successively by the red marle, the lias, and the oolites, the strata generally having a gentle declivity in the direction he is going. As he approaches the chalky downs, there is commonly less of umbrageous verdure and grassy luxuriance, and the country looks drier and more sunny. There is a return, however, to some extent, to a rather hilly character in the ridge of elevated ground which he now sees stretching far away to his right and left, S.W. and N.E. obliquely across our island, constituting a remarkable geological demarcation between older and newer strata, an offset of the ridge also stretching south of the Thames to the Kentish coast. In coaching days we recollect passing the ridge in Berkshire, and seeing the white horse on the hillside, but 
in railway times we have become better acquainted with the Buckingham and Hertford part of it. When we draw near London on a calm summer evening, we are struck with the bare sides ands still repose of the rounded hills, their flanks traversed by the white lines of chalky roads, and their brows shadowed, it may be, with woods of beech or fir. Those little villages at the foot of the hills, with their antique church towers rising from amidst clumps of trees, how sweetly are they embosomed in the hollow dells, or reposing lower down in the richer valleys! And there is much to interest in such localities-much that is peculiar to them; and with respect to them - such capital botanical grounds - the writer confesses to a particular vanity, shown in a little extravagance: he likes now and then to be put down at some station for a day's ramble, or, what is sometimes more convenient, for one or two half days. Then business or friendship may have induced him to visit (not to accept) the Chiltern Hundreds. The nightingale has enravished him, and the glow-worm has lit him in his evening walk from the railway to the pretty little town at some distance, both bird and insect almost unknown in many districts of northern England. This is a trifle, but we may find matter for deep inquiry in the presence or absence of particular objects-plants especially-in the chall district. Whence this peculiarity? Of course, contingent upon the nature of the soil; but how and when was the distribution made?-was the distribution geographical or geological? And were the several distributions-say of the mountainous flora of northern England, of the limestone, of the cretaceous districts, and so on-contemporaneous?

Again, has any one domiciled for half a life in one 
of our busy manufacturing districts, with a taste for the archæological and antiquarian as well as for the rural, yet obliged, for six days in the week, to pace the ugly streets, and on the seventh to worship in one of the tasteless modern edifices often found in such localities-surely it will give pleasure to survey a landscape untainted with the smoke of manufactories, and to attend service amongst the russet coats at some retired country village. So it is with us, at any rate; an uncontaminated rural scene is what we have sighed for for years-what we love. All old churches, too, are our friends; we love to visit them on work days as on Sundays. Of Tring Church, at least of the interior, we recollect little, except that it contains some ancient monuments, and the clerk showed us the spot in the aisle where one of the gipsy kings was buried in great ponp. These queer people are, at any rate, good churchmen, but in their own way; and this applies to other folks besides gipsies. The tower is stuccoed. I leaned on the gate one market-day, watching the proceedings of the buyers and sellers of straw-plait, here the staple commodity; straw hats were in vogue, and the trade was lively. When an offer was rejected, the Buckingham negative was invariably ' now'-a match, we thought, for the Moorland 'yoi.' We suppose the traders came to terms later in the day. On two Sundays Drayton Beauchamp and Ivinghoe attracted my steps. At the former place is to be seen the monumental brass of Thomas Cheney, shieldbearer to Edvard III., from whom he had the manor; also the costly tomb of Lord Newhaven, and some stained glass. The judicious Hooker was rector here. I caught a large Sirex in the window of the parsonage, much to the relief of the inmates, who were 
sadly afraid of it.* At Ivinghoe were some ugly mural paintings, and an altar-tomb with effigy, whose it is being uncertain; Lysons believes, of Henry de Blois, brother of King Stephen; Brown Willis, of Peter Chaceport-one of those incertitudes, which, fortunately, are of little importance. All these villages, as well as Pitston, lie on or near the Roman Tkeneld Street, locally called Acknell Way, $\dagger$ running across the railway at the foot of the lilly ridge.

The hills to the left appear the most commanding, and I start about the end of May to climb them. Cineraria integrifolia was the first novelty I met with; there was also Anemone pulsatilla, but then over; the Cineraria just coming into flower. Many of the plants in the fields were the same as occur in limestone districts in central or northern England, as the Salad-burnet (Poterium), Galium verum, and others; but some were not so, as the Guelder rose (Viburnum opulus), the wild Mignonette (Reseda lutea), and Clematis. The white Bryony grew together with the black, and there were other plants often found on the red marl-Hypericum sylvaticum, the Buckthorn, the hoary Plantain (Plantago media), Origanum, and Galeobdolon. The mustard took the place of the charlock here in the cornfields, and Trifolium incarnatum was common in them. But the botanist comes

* My friend was an antiquary, but he had no taste for natural history ; the present Rector is well known as an eminent entomologist, and as always ready to impart his information.

+ As in example of the bucolic corruption of a Roman name, I may relate, that once making enquiries respecting Etocetum from a country fellow, demanding whether he had ever noticed any walls, tiles, and so on, he shook his head, particularly at my version of the name. At last he exclaimed, as the light shone forth, 'Oh, you mean Hekum Sokum!' and shortly produced one or two Roman coins found thore. 
here principally for the Orchidex, and there are some rare species in the woods crowning the hills, to which we will revert. Making our exit from these woods, there is a descent into a pleasant valley of flowery fields and meads, with other chalk hills on the opposite side, diversified with woods, and having a striking obelisk rising up among them. Aldbury has old elms, old timbered houses, and an old church, as it should have, from its Saxon name, the tower of the church looking rather remarkable from the absence of parapet. I peeped in through one of the south windows, under which was a tomb with male and female effigies. Some young folks were plaiting straw under one of the trees; enquiring from them I was told the effigies were those of Harcourts, which may be the truth. At one village in another county, I was told that two such effigies represented Adam and Eve! Asheridge Abbey near Aldbury, Lysons says, was founded by the Earl of Cornwall (1290), and belonged to the religious order of Bonhommes, who wore a blue habit. The founder, amongst other' endowinents, gave it a portion of sanguis Salvatoris, which the Bishop of Rochester caused to be exposed at a sermon of his at Paul's Cross in 1538, when it turned out to be honey clarified and coloured. Mounting the hill opposite Aldbury by following up one of the hollow roads so common on chalk hills, I came to a long common, with occasional traces of a former forest in old oalss, beeches, or hollies. The woods and fields abounded with pheasants, all of which had a ring of white feathers round the neck. On the common itself pedlars, gipsies, and real shepherds might have been studied to advantage. Paris quadrifolia, Helleborus viridis, and Euphorbia amygdaloides occurred as Northchurch was neared, 
and there was an enormous Heracleum in a hedge, doubtless an interloper, but evidently now quite at home. The grounds of the ancient castle of Berkhampstead-for little remains of the castle itself, except a few fragments of walls built of strong mortar and flints - must be a boon to the inhabitants of the little town, from the shady walks encircling them. Several of the Conqueror's moats are still full of flowing water, in which cresses are grown for the London or Birmingham markets. Other's were full of still water, covered with duckweed and other aquatics, and abounding in molluscs, crustaceans, rotifers, and indeed in life of many sorts, of which more at the end of the chapter.

If we walk in the opposite direction from Tring along the ridge to the right or south-west, we shall traverse the best botanical ground to be met with here. In Tring Park we shall admire the magnificent horse-chestnuts, and as we go on (if we are at the right season - the end of May) shall soon stumble upon Iistera nidus avis, occupying the bare ground under the gloomy beeches, and higher up at the skirt of the wood upon the Fly and Bee-ophrys. The shell collector may find a large Clausilia on the stems of the beeches, Azeca, Pupæ, Cyclostoma, and various Helices, as $H$. virgata in abundance. I dissected this last named little snail; it had two of the curious little stylettes, or darts, one of which is common in the Helices. Further on the lesser Winter-green or Pyrola minor; Phyteuma orbicularis; the Spurge laurel, or Daphne laureola; Solomon's seal, or Convallaria multiflora ; Chlora perfoliata, the Columbine, the Juniper, and many other plants occurred. Productive ground, in the shape of beech and fir woods, bushy thickets, scrubby dells, and furzy hills, may be followed for 
some miles till we emerge, at Aston Clinton, on the Aylesbury and Tring roal. Other rarities also occur in their season, and in localities commonly somewhat limited.*

The Norfolk plover is frequently heard in a summer's evening upon the range of chalk hills, about Tring, and also the brown owl from the skirts of the dark woods. The large reservoirs situated near Tring offer inducements for a great variety of aquatic birds to frequent them, for breeding purposes, or for food; the bittern, teal, and poachard, for instance, breed there, as well as the pretty little bearded tit. The mountain finch arrives in great flocks to feed on the beech mast, and the hawfinch frequents gardens, whence the cottagers call it the peafinch. The siskin and the grasshopper-warbler are not uncommon, the cirl bunting breeds in the juniper scrub, and the quail and hooded crow are seen in the open fields. The badger, the dormouse, the polecat, and the pretty little harvest mouse occur, the latter in the growing barley and barley-ricks. Truffles are sometimes dug up in the beech woods. About twentynine species of the lepidopterous genus Eupithecia have been found by the entomologist already alluded to, including E. campanulata and E. arceuthata; Noiodonta cucullina, Gluphisia crenata, Lycana Adonis, and Nemeobius Lucina are also lepidopterous insects of great rarity or interest, and found in the district.

For an afternoon's excursion from home we will go ofi in an opposite direction, and be set down in a

* Monotropa hypopitys, Mclampyrum cristatum, Epipactis grandiflora, Herminium monorchis, Orchis ustulata, and O. militaris, Spiranthes autumnalis, Gymmadenia, Fritillaria, Gentiania Germanien, and Iberis amala. 
very different region from those chalky hills-in the Clieshire plain, with its mosses and meres. Parts of the neighbouring counties also partake of the same characters. Here we are not very far from that great junction of iron roads, Crewe, where wheel, hammer, chisel, and file are ever plying; yet, if we wander a short distance from one of the stations, we are soon lost and buried, as it were, in stillness and obscurity, following sandy lanes across the perfect flat, and unless we know the district, we shall be soon confounded and lost. These lanes go in all directions, leading everywhere, anywhere, and nowhere-at least, in a straightforward manner. The inclosures are numerous, and the country thickly wooded; we look around, without a chance of seeing any eminence or landmark. But everything looks luxuriant and rich, and we frequently come up to one of those noble timbered louses buried in orchards, for which the county is noted. It is dubious, if we attempt to consider the point, under what conditions the great beds of sand and drift, of which the surface is composed, have been deposited. The fields, though feeding the cattle producing the famous cheese of the county, are somewhat beggarly-looking, and often more or less peaty. Round pits occur here and there, often very deep; indeed, the Cheshire boors will tell you that some of them will swallow up the steeple. They often produce interesting plants, as the white Water-lily ( $N y m$ phoea alba), Burweed (Sparganum natans), Quillwort (Pilularia); also Centunculus and Nitella pellucida. They abound, too, with insects and microscopic creatures. The water spider (Argyronecta) occurs in some of them, and with some care may be well kept in a glass jar, in which he will form his curious domicile filled with air, which is carried down from the surface, 
attached to the hairs of his abdomen. Care must be taken not to drown him out, and also to place some plant in the water by which he can ascend to the surface, and to which also he will attach his nest; the only remaining difficulty will be to find him food, and to prevent the colonists from destroying each other. A pretty little Planorbis also is found here, very minute, the shell having a false appearance of being chambered, like the Nautilus; its tentacles are prettily ciliated, and have eyes at the inner part of the base. Aqualate Mere* is a large sheet of water, perfectly oval; the name is not modern, it seems, but Roman, for remains of that ancient nation have been found on its margin. In its inlets occur Frog-bit (Hydrocharis), Water-violet (Hottonia), and numerous white Lilies, the flowers of which, we noted that some bird was in the habit of pulling to pieces.

But what is a more curious feature in this plain is the presence of what are called mosses, which occur so frequently, though many are fast disappearing from drainage. The lover of nature will always be interested and amused when he gets upon one of them. They differ somewhat from the morasses found upon mountains; they are perfect flats, with strata of sand under the peat, and are often surrounded with groves of fir or birch, the former no doubt indigenous, we should suppose, as their cones are found deep in the peat, though, it is said, only in the lower part. This peat varies in thickness, and querns, paddles, and horns of deer have been brought to us from them. When the peat is entirely removed, as is done for fuel, there seems to be little tendency for it to be formed again.

* On the Staffordshire border. 
And now for the exploration of one of these mosses. We should begin by following up for a little distance the stream that runs from it through these small meadows and marshy thickets. The water is clear, but slow in motion, and if we are microscopists we may get Confervæ, Desmidieæ, and Diatomeæ; and here in the thickets are the Loose-strife (Lysimachia) and the Meadow-rue (Thalictrum), and probably the rarer great Spearwort (Ranunculus lingua), for it delights in such places. This bush is the berrybearing Alder (Rhamnus frangula); here is the sweet Gale, and here are sallows and several varieties of a pretty willow, Salix fusca. And now let us attack the moss proper itself, at first rather bushy, or with high clumps of tussock Carex; boots and a stick will be well, for about these clumps vipers abound, and no sooner thought of than one appears. On one occasion my friend killed one, and we took it home in an empty botany-box for dissection. Then there was the opening of the box. Suppose it was only scotched, not killed? As is well known, it is viviparous-unlike the common snake in this respectand probably some young ones will be found in its interior, with a frog, mouse, or bird at this swollen part. Blind worms, too, are numerous, but they are harmless. Many dragon-flies and marsh Lepidoptera are flitting about. Here is Polypodium oreopteris, somewhat fragrant when bruised, and also plenty of the much rarer Aspidium cristatum, of which we will take a root or two. Here is the Cladium mariscus, a discovery of my own in this locality, and the rarer Scheuchzeria, that of a friend.* And now, with a

* At Wybunbury MIoss, Saxifraga hirculus, a plant now rery rare in England, still grows, I am told, on Dane's Mioss. 
little caution, we venture upon the spongy portion of the bog; strange enough, it evidently has once been ploughed, or at least dug, and the gutters are filled with boggy water. Here is the locality to find the three species of Drosera-D. Anglica, in rather grassy spots; D. longifolia, where it is more muddy; and D. rotundifolia, on bare mossy surfaces. The contractility of their leaves has been denied, but it will be found, when we remove them from the box, that many of them have curled up. In the water is the Bladder-wort (Utricularia vulgaris), also the rarer species $U$. minor-plants well worthy of study. There is also the beautiful Andromeda, looking like some rare exotic or choice garden plant. Here is the crowberry, with its black fruit; and here tufts of the cranberry, with its pretty flowers, or large spotted berries and straggling stems, called here cranberry wires. Probably the keepers will pay us a visit soon, for they are on the look-out for cranberry stealers; our boxes will speak for themselves, and for us too. The cowberry (Vaccinium vitis idaca) is often sold for the cranberry; amongst the berries may generally be found a leaf or two, and those of the cowberry are like box-leaves; in the cranberry they quite differ, and it has, too, a larger berry, often spotted, and with a. delicate style at the top, and fine stalk at the base.

All the above were found on the moss in question, and in one visit; but there are also in the same place, or close at hand, many other plants of similar habitat-some rather rare Umbelliferæ-as Phellandrium fistulosum and Helosciadium inundatum; the grass of Parnassus, or Parnassia palustris; Polygonum minus; Mentha pulegium; Genista Anglica, with its sharp spines; Cnicus pratensis; the lesser Reed-mace (Typha angustifolia); the handsome Carex pseudo-cyperus, 
Lycopodium inundatum, and the noble Fern-royal (Osmunda regalis); and here, curiously enough, on this dry sandy portion of the waste, is Botrychium lunare, commonly considered as a sub-alpine plant. Here, too, is the pretty Butterwort, or Pinguicula vulgaris, which we will grow under a bell-glass with the cranberry-Droserce and Bryim punctatum. The little boggy pools are purple with a Conferva (purpurescens); we will secure some, and a little of the water from the Sphagnum, and then shall take home two microcosms for the microscope. Here is a curious fungus (Spathularia flava), growing on some wet rotten leaves in the dyke bounding the moss. What pretty pearly stems, with rich amber-coloured knobs crowning them! Surely we have now enough for home examination. But stay! Before we leave off we must have this tuft of Splachnum ampullaceum, one of a pretty genus of mosses always worth having.

And now let us try to find our way back to the station. The line is evidently not far off, by the whistle and clack of the engines; a short walk brings us to it.

Thus the rock, the mountain, the river, the lake, the morass, the shore-all yield up their treasures to the devotee of Nature and her works, and we may choose one branch of study, if we wish to make discoveries, or, as the writer affects himself, be more general in our pursuits, not profound in any one, but capable of deriving enjoyments from many. What a profusion there is in Nature! - how wise and bountiful is the Creator! What enjoyments!-how much to admire and wonder at! What contrivances for us to study! This seems to be created for beauty; this with wonderful function or use; these to try our powers in the investigation, or skill in the classification of them. Alas! these ideas are crude, but we 
cannot but speak well of what has been so much pleasure to us.

But summer does not last the whole year, and autumn, though pleasing to the poet and artist, is sadder to the naturalist. Nature is dying; the bee or fly hang's torpid on the last flowers, and allows us to seize it with the hand. Some of our old friends amongst the shrubs and herbs now puzzle us, from our seeing them at present in a less noted condition; birds of passage are taking their flight, the summer ones to happier climes; others coming to us from more wintry lands than our own; and others, shy and retired during their great work of rearing young, again slily approaching our dwellings. The trees are becoming bare; there is nothing to attract us abroad, and how shall we get through the winter? Well, the morass, or moss, or marsh, naturally leads to aquatic and microscopical animals, in which they abound; as, indeed, do also our rivulets, pools, and ditches. Let us stock a little tank or two, or at any rate provide ourselves with a few jars and bottles of water, with. a few plants growing in it,-Chara, water-violet, Myriophyllum, pond-weed, or Valisneria, and we shall have a prolific field for both amusement and research in our drawing-room and by our fireside-that is, if we are worth a microscope: And now, say the time is November, the first water we take will probably furnish species of those minute regetable beings called Desmidieæ; here are Closteria, shaped like the moon of a day or two old, and presenting some appearance of a circulation internally which has been supposed to be due to ciliary action, and also of a movement in the particles of bright green matter, or endochrome, which its interior contains. Ciliated ani- 
malcules, too, of the genus Chætomonas are seen in the extremities of the dead plants. The pretty Cosmarium margaritiferum is of a different form, and less frequent. Amongst the brittlewort, and in the stone basins of gardens, one may find those beautiful reticulated or multicellular star-like disks or tablets, called Pediastrex, having, in the species before us, fourteen cells in the outer row, eleven within them, and six in the centre; the outer one with radiate processes, all of them punctuated and containing green matter, but leaving interspaces beautifully clear. A jar of water with Myriophyllum, which had stood through the winter, had a green colour, which depended upon the presence of the desmid called Scenodesmus, each individual formed by four oblong cells joined together side by side so as to constitute another larger oblong figure, with a little hair or bristles growing from each corner of the compound body. Besides multiplying by self-division, the cells seem to burst when the plant is mature, and give exit to little green particles or germs, forming other Scenodesmi by fissure, analogous to what also occurs in Pediastrum. The little plant was abundant, and free from other organisms, except a few specimens of a species of the same genus; it was allowed to dry on one or two glass slides, and formed an interesting permanent object.

To account for the prevalence of these minute plants-for plants both desmids and diatoms probably are-we must recollect that the higher vegetables are essentially composed of nucleated cells. But here we have, in each case, a simple unit of the many which compose a shrub or tree, the essential phenomena, however, being the same, though seen in an isolated form. We have the same kind of multi- 
plication of the individual cell, producing, in the higher plant, its growth, not its duplication. But, besides this multiplication of the individuals, the continuation of the species is provided for by the conjugation of two individuals, and the formation of a sporangium or capsule of germs, or of a single germ or spore; but of the numerous modifications of these processes we must leave the microscopist to take his own view.

Those naturalists who, of late years, have hunted for Diatomacer, and have brought so many species to light, have done good service. Formerly but few species were known; now they constitute a new world of little beings-little, but beautiful. We suppose we must call them vegetables; they have not the green colour of desmids, however, and these boat-shaped Naviculæe show a curious locomotion forwards and backwards, with an occasional turn on their short axis, to us appearing to depend upon cilia, or some such processes, though this notion is controverted by the best observers. Diatoms are of world-wide abundance, and if we search for them, it will not be long in vain. In this slimy ooze, thrown up by an inland river in spring time, are seen interesting Pleurosigmas, shaped like the letter S, also Triblionella gracilis, in shape like the sole of a shoe with cross scorings, and Cocconeis of an oval shape, with a longitudinal line. The stalks of this chara, that have been kept all the winter, are covered by the Gomphonema constrictum, a species which is branched and tree-like, bearing wedge-shaped frustules, which are prettily ornamented by studs. Here, in April, is the delicate Fragillaria; in a ditch filled with water starwort; and in another little rivulet, upon examining the brownish flocculent matter, it is found to consist of 
the beautiful Meridion circulare, ummixed with any other species, and having its circles complete. It is so abundant that I might supply all the microscopists in Europe with it, but it is liable to be disjointed by the strong acids which are necessary to remove the organic matter from the silicious valves, for it is the silicious testa of these organisms which we commonly see preserved as permanent specimens. Along the margins of canals Diatoma vulgaris may be commonly gathered, adhering to the tufts of Confervæ, and a diatom evidently allied to it is Asterionella, which one might take for the radiated spicules of some fresh-water sponge, and indeed it abounds in water in which the sponge grows; but a little examination shows the difference. The little rods of Asterionella adhere together in a star-like manner by their swollen bases; the other extremities are more attenuated, but still a little swollen; the rays are from six to sixteen. What is curious is, that the rods sometimes arrange themselves in a zig-zag or figure of $\mathrm{M}$ form, sometimes in that of a double M (M M), surmounted by other rocis, as well as based upon them, and these rods themselves often forked with others like the letter $Y$. The rods bend upon each other, and some are double. Here is a diatom (Ceratoneis) from a shady pond, of a very long spindle shape, which might be set down for a desmid, or even for the germ of a conferva; it presents a sliding motion. Here is one, a compound species : you would take it for a seaweed, like the Ectocarpus, with which it is found; but its minute branclies will be seen under the microscope to enclose multitudes of boatshaped diatoms-it is a Schizonema, and I picked it from under Bangor Suspension Bridge. At the same time and spot were collected Pleurosigma hippocampus 
and Balticum, and several pretty discous forms-Actinoptychus senarius, Cyclotella, and Coscinodiscus, besides a living Rhizopod, probably a Miliola. The formation of their flinty coat by diatoms is a remarkable phenomenon, but we see an analogous thing, perhaps, in certain cells of higher plants, as in those forming the silicious cuticle of a cane or grass. In inland situations, (except where fossil infusorial earth occurs,) and in fresh water, the pretty circular discoid forms are absent or rare, as are those beautiful forms named Polycystinæ. An old friend, E. Quekett, the author believes, was the first to point out the productiveness of guano in such forms. The extreme beauty of diatoms is often best seen by viewing them under the deflected light of the parabola. The markings of many are difficult to distinguish, as those of Hyalodiscus, or, still more, those of some Pleurosigmas; some young eyes fail to make out the former, when, to older and worse ones (in some respects), they seem plain enough, exactly like the engine-turned back of many watches, with a plain disk in the centre. A good light, or the achromatic condenser, is sometimes necessary. The simple microscope is now commonly discarded, but a good doublet shows such objects as well as the compound instruments, though more tiresome to use; it is also best for the dissection of minute objects.

Infusory animals are extremely interesting to observe, but at present much difficulty and doubt attends their physiological and systematic study. We here refer to the very simplest forms of life - so simple, that there is little by which to distinguish one object from another. The life-history or biography of scarcely any one species has been investigated throughout, and consequently we are often 
ignorant of their development, or, it may be, metamorphosis of form-to say nothing of the difficulty of observation. To facilitate the latter, glass troughs are useful, but they do not confine the animalcules enough for observation by powerful lenses; with these, cages and compressoria must be called into requisition, and even then it is often difficult to observe such minute and active creatures as monads, unless they occur in swarms.

Vibrios are extremely minute animalcules, though by some they are considered to belong to the vegetable kingdom. They make their appearance in water and other fluids at the first approach of putrefaction, consequently mostly when there is a taint of organic matter : they disappear when the putrefaction is over. They occupy the same position in the above decomposition or fermentation as the yeast or vinegar organism does in other fermentations. Some have believed that they may take a part in the production of disease. It is also a subject for speculation, whether they may originate from dead organic matter without the accession of germs from the atmosphere, or, in other words, by spontaneous generation. Particular species originate in particular liquids, as in infusions of oats, hay, or bread; each liquid having a difference in the products.* Sometimes they first appear in a gelatinous mass or stratum, defined and lobulated, and floating in impure water, called Zoo-

* They are tolerably erowded in filtered sewer water, though the latter is eertainly much purified by that simple process. Uvellx, and other animaleules, aceompany the ribrios; but all, as well as animaleules of higher organisation, are killed by a minute quantity of permanganate of potass diffused in the water, or by a still more minute portion of carbolie acid. Kreasote works, when situated on the sea-shore, appear to be very destructire to animal life. 
glæa, and often a fibrous and gelatinous fungus ( $M y-$ cinema or Leptomiton) accompanies them, with many motile germs or minute monads. Indeed, the latter often accompany vibrios, or succeed them in an infusion, as in that of hay, where they have a round or oval shape with internal dots and external filaments. Some vibrios are staff-like, or have a junction in the middle, and move slowly; others are like portions of a necklace of two or many beads; others filamentous and corkscrew-like, very vivid in motion. The staff-like forms in some cases seem little different from Oscillatoria, and indeed possibly grow into them. These last-named organisms are occasionally developed in great quantities in still marine tanks, the filaments of a fine olive-green colour, beautifully striated, and actively bending backwards and forwards with their peculiar motions.

When we say, in homely language, that we can often neither make head nor tail of the monads, we express the truth. Many of them, no doubt, are motile vegetable germs, or spores belonging to Algæe or Fungi; others early forms of higher animalcules. The larger monads are more satisfactory. One, which appears to be Heteronema marina, is found in immense shoals, visible to the naked eye, in sea-water or marine tanks; it has two long filaments or lashes proceeding from a sinus near the front, cansing its very rapid movements. It, perhaps, belongs to that division of monads which have a theca, or external casing or integument - cryptomonads. There are monads, or monad-like animalcules, fixed at least for one portion of their lives upon the summits of the branches of a little tree-like body-Anthophysacommon enough. There are also aggregate monads, forming a mulberry-like body, rolling about in the 
water of ditches or pools, particularly in the spring months, by the action of the cilia or lashes which each of the component monads possesses-Polytoma and Uvella.

The name Flagellata, though applicable to some monads, is particularly so to some other forms of microscopical life, including, perhaps, nembers both of the animal and vegetable kingdoms. Such organisms are distinguished by the presence of whip-like processes, extremely attenuated, the movements of which produce locomotion. In some green water from a tank, the colour depends upon oval or rounded bodies filled with greenish endochrome, and having each a clear vesicle, and two fiagella or lashes causing them to move about vividly, or sometimes to anchor themselves by them. No doubt these moving bodies are the same as others seen in the same water, four in a group, and forming tables by help of a clear envelope, the groups moving along through the water by means of the same processes. In another form they are still enough, increasing by fission into twos and fours, like other Algre. Sometimes the roundish bodies appear to break up, and give origin to minute germs (microgonidia). By these germs there is, perhaps, the formation of a new generation; by fission, a multiplication of individuals. This was probably a Chlamydococcus. Similar phenomena take place in a common Palmella, found growing upon aquatic plants-a clearly enough vegetable, though its loose germs are motile. Gonium pectorale, so called from its resemblance to the Jewish high-priest's breastplate, is a beautiful form, and commonly met with, composed of sixteen greenish globules enveloped in a disk of clear membrane, rotating buautifully on its short axis by means of the cilia or flagella; 
each globule may be seen to form sixteen other small ones before it breaks out. Volvox is a wellknown and interesting, as well as a beautiful object; it is found in most pools, and is visible to the naked eye as a revolving and progressing greenish globe, having daughter's in its interior, and granddaughters, in the same way, embosomed in the second generation. All these, with the allied Uroglenæ and other families, are generally considered to belong to the vegetable kingdom, if the two kingdoms are distinct in such beings. The Uroglenæ are not in appearance unlike the ova of sponges, themselves motile. Astasiæ and Euglenæ are an advance from the monads, the latter of the two marked by a brilliant eye-speck, so called. They abound in summer in pools where timber has lain, in engine-pits, in water-butts, and sometimes in water from mines. One pool showed a remarkable appearance from the presence of immense numbers of these animalcules; they gave the water a green colour usually, but after the bright sun had shone on it, the surface presented a brilliant red colour. They have in some species only a cilium or flagellum, present little internal organisation, and are often flask-or spindle-shaped, or sometimes roundish, but the shape is liable to change in each individual. A very pretty animalcule, a good deal like the Trachelocerca or swan-neck (to be mentioned again), except for its small size, has an oblong but variable body, blunt at the posterior extremity, and having in front a flagellum or whip, which curiously paddles the water: it corresponds to the Astasia limpida of Dujardin, thougl its clear eye would indicate it to be an Euglena. It does not appear to be very different in character from Peranema protracta or Trachelius trichophorus: one suspects many of these 
little forms have several aliases. Like others of the Astasiæ, it has a nucleus and other marlings in its interior. I have found Dinobryon common in onc pool amongst the American weed-a minute animated cell-bearing bough or branch, each cell having an Astasia-like animalcule, and the whole moving: through the water by means of the flagella. The animalcules at present described are called Phytozoa, a good name, because it may apply to the objects, whether they are plants, animals, or a kind of hybrids of a mixed nature, which appears to us to be often the case even in higher forms of so-called animal life, in a star-fish or Sertularia, for instance.

Next follow the Protozoa, which are mostly of an undoubted animal nature. Some Rhizopoda are remarkable for forming beautiful shells, and for these we must search sea-weed or sea-soundings, rough shells, madrepores, shell sand, or (what will yield a good find) the sand from the boxes in which drysalters keep their sponges for sale. This sand yields Miliola, Paneroplis spirolina, rectilinea, and dendritica, Orbicul; za, Orbitolites, Polystomella, and Discorbina. I have generally separated them by rotating the sand in a shallow vessel, the lighter shells coming to the surface; but probably washing would answer better. One may occasionally meet with living specimens of some genera, as the writer has recorded before. Amæba is a naked rhizopod, common in fresh or salt water; it appears to be but an animated bit of transparent jelly, with, however, a nucleus and some granules; it slowly but constantly changes form, throwing out arms or processes in a most bizarre manner. It has no visible mode of taking in nourishment, but must form an extempore mouth and stomach. Gromia is lodged in a membranous pouch, and its long feelers 
curiously anastomose; it occurs in fresh water, but does not appear very common. Difflugia has a hard, dark-coloured shield, and occurs often enough in both salt and fresh water; on watching the little round caps, we shall soon see the delicate arms or feelers protruded. Actinophrys is a pretty sun-like disk of sarcode or jelly, its rays very long and fine, their terminations like those of light rays, not to be seen; it is most common in long-kept sea-water, and sometimes two are seen with a bridge, as it were, connecting them, or seren or eight may be conglomerated; they may also be seen to seize and embrace neighbouring particles for nourishment: we have never observed any quick movements in them, though others have. With these the Acinetre seem to have an affinity-at any rate they may be mentioned here; they are stalked, but the stalks are not always attached, though they are sometimes so-to Sertulariæ, for instance; they abound both in salt and in fresh water; they are commonly of an oval or triangular form, furnished in front with tufts of beautiful rays, finely capitate at the ends; no figures come up to them in delicacy. Stein believed that Acinetre are still forms of Vorticellø, but they take in food, and undergo self-fission. Many kinds of Infusoria, indeed, sometimes envelope themselves in a sort of adventitious membrane or cyst, and put on what is called the still or encysted form, so to remain probably for the winter months. The Vorticellæ appear like the family of Acinetina at first sight, but they are open cups, or, at any rate, have mouths and vibratile cilia at their summits; they are equally or more beautiful in appearance, with the cilia in vivid action at times, but sometimes retracted. Opercularia, Epistylis, and Carchesium are examples-we need only to search, with 
the pocket-lens, the Hypnum ruscifolium, found in wells and clear rivulets, to meet with examples, or even the surface of shells and of monoculi. Cothurnic maritima occurs in every salt-water tank, being a crystal cup with one or two trumpet-shaped polypes within; the whole either sessile or detached, and when the latter, moving about by the action of the cilia situated around the mouth of the polype. In the same way the Vorticellæ move about, when detached, with or without their pedicels; in the latter state they exhibit somewhat the normal contour and configuration of the Stentors. One of these (S.niger?) we have found in great numbers in a marshy pool. The Vorticellæ, when detached and stalkless, are very like some Trichodinæ, and Cyclidia, and also Halteria; all have the same rapid and desultory movements, rendering their observation very difficult; now they are stationary and rotating for a moment, soon suddenly darting off like a shooting star. A radiate disposition has, up to this point, been often noticeable in these infusories, as it is also in Chætotyphla, a little cup-shaped creature, ciliated, and with some processes at its truncated base, which advances first in its rapid course, the animalcule rotating at the same time on its long diameter; it may be found in the warm tanks of stove-houses. Peridinia are, at least in such species as are found in fresh water, somewhat top-shaped, with a constriction in the middle, having a row of cilia in it, also a sort of bristle or tail behind, the whole surface being rough or reticulated: its movements are much like those of the last species. Coleps is a little hairy, barrel-shaped, and reticulated creature, often very numerous in summer, looking dark from its opacity when seen by transmitted light, but in reality white, when seen by reflection from its surface. 
Leaving the radiate and branched Protozoa just mentioned, the remainder of infusory animals, with the exception of the Rotifera, may be especially called Ciliata; they might be considered to be the representatives of the Mollusca in the microscopic domain, as those already described might be-of the Radiata; and the Rotifera - of the Articulata. These now to be mentioned are richly ciliated, and move about by that peculiar provision. They must be small necessarily, for large organisms could not be moved on such a plan. In other respects their organisation may be varied; the lowest have not always a mouth nor alimentary canal, and may still increase by fission, but the higher forms have the internal digestive sac, with mouth and vent, also in some cases distinct sexes, and may be oviparous or even viviparous. The Enchelia are perhaps the least advanced, but have an anterior and posterior opening to the digestive canal. Enchelys proper is so organised-still it has a nucleus, in accordance with the supposed singlecell origin of such animalcules, and besides a contractile vesicle which is probably an organ of circulation, as it varies in size frequently. The cilia in Enchelys occur at its mouth only. Leucophrys, allied to it, has them on the whole body; the lengthened forms of some species, as of Spathidium, are strikingly characteristic. Lachrymaria has an elongated neck, and is a good deal like the Trachelocerca or swan-neck animalcule. Prorodon has an appearance of teetl at the mouth, with an oval form. In the family Trachelius, the mouth is lateral, being at the base, not at the extremity, of the rostrum, as it was in many of the previous forms. Trachelius and Loxodes are found in fresh and salt water, and have considerable diversity of figure; some ratker appear to rank 
with such Entozoa as distomes, or with Planaria, and some have two eye-specks. Amongst Lemma occurs a species of free distome, very like those affecting the bodies of Lymnæus; it is somewhat oblong or oval, a little broader in front, with an adhesive disk there, and another near the tail, which is very moveable and extensible, and which it lashes about in a figure of 8 form, and so swims rapidly; at other times progressing by its suckers. In a species of Loxodes (ovum), which occur's in impure water, and in Bursaria truncatella, the internal structure may be well studied, particularly by causing them to take in particles of carmine or indigo: such were the species and the mode of proceeding in the investigations of Ehrenberg, Lieberkûhn, and Lachman.

Spirostomum is a large ligulate animalcule, common in ponds, and visible to the naked eye. Chilodon, like Prorodon, has a dentate appearance of the mouth, but this is not at the anterior part of the body; in Nassula there is a similar organisation, but the body is less flat and less hatchet-shaped. Glaucoma has its mouth with a peculiar tremulous flap. Trachelocerca appears but little removed in reality from the Trachelius, but is remarkable for its very long neck, and oval or somewhat spindle-shaped body. It progresses with either extremity first, in an extended state, or by a serpent or eel-like waving of its neck, or it curiously twists itself in all directions amongst aquatic plants. Trachelius proper is generally to be known by its lanceolate and swordor hatchet-form.

Still higher beings are Kolpoda, Paramecium, and others. They may probably have longer cilia at the mouth, or a sort of tongue in it, and both mouth and rent at the side of the body. They may also have 
visible digestive cavities, organs of reproduction, and eye-specks. Paramecium abounds in water somewhat passé, with Chilodon and Glaucoma.

Next occur Infusorial with more complicated organs of locomotion. To understand their classification, we must learn the meaning of the terms used to distinguish these organs-cilia (vibratile hairs); setæ (bristles); styles (pins); uncini (hooks); and cirrhi (curled hairs); by them they creep, climb, or swim, and often with sudden starts backwards. They are amongst the most common of animalcules. Oxytricha has the two first appendages; to Kerona, uncini are added; to Urostyla, styles instead; Stylonychia has the four first. Some, as Euplotes, so common in sea-water, and Aspidisca, have well-marked transparent shields on their backs; in Coccudina the shield (lorica) is arched and furrowed. Some species, as the Euplotes, mentioned above, are beautiful objects.

The Chrtonotus is a common little creature, a sort of miniature Eolis, creeping or moving by means of cilia, long in form, and hairy on the back. Its specific name is larus (a gull), but we don't see that it is like one, nor much like a rotifer, though it has a forked tail-if like a gull, it must be a bird without beak, wings, or feet. Others of its congeners approach the encased rotifers, particularly that group called Ecistina. Chrotonotus has no eyes, other allied species have. Turbanella appears to be an allied form. That beautiful and more perfect mimul Tomopteris is occasionally found in fresh sea-water, but it is evanescent in the marine tank.

Of the true Rotifera which to us appear to be allied to the Crustacea, some form for themselves a tube to live in, and are extremely beautiful, as is so well displayed by Gosse; other's are naked and free, 
and from their elegance, varied forms, and habits, afford also many inducements to lead us to observe them. In salt water they are not generally abundant, but two species are so: one appears to be Colurus uncinatus, occurring in tanks very commonly; the other is Synchceta Baltica, more choice in the quality of the water, but common in. sea-water from the inoutl of the Mersey, and from North Wales. This is of a pyriform shape, with some spines in front, and two ciliated processes like ears, one on each side; these last produce powerful movements. We have discovered that the little creature moors itself by a cable, which it spins from its tail, and can nip when it likes; when anchored, it revolves in rapid circles. The thread may be seen by the quarter-inch power, or be made out to exist by the minute particles caught by it. Cohn mentions something of the sort in Hydatina senta, acting in the same way, but more imperfect. Of these Rotifers, more than twenty species were found in two or three pools infested with American weed, and into one of which some warm water from an engine was frequently discharged. The most interesting were Microcodon clavus, which displays a beautiful crown of cilia regularly spread out, whilst the creature remains quite still in the water so as to form an exquisite object for observation; Notommata tigris, often found with the last, having a long and remarkable double tail ; $N$. aurita ; Polyarthra platyptera, or the sword-bearer, with its many long processes; the long-tailed Mastigocerca carinata (found also in the Matlock waters) ; Triarthra longiseta (likewise obtained from stove-house tanks); also Noteus quadricomis, Brachionus polyacanthus, and urceolaris, Anurcea heptodon, Dinocharis pocillum, Pterodina patina, and Euchlanis triquetra. Some 
Rotifers have both male and female individuals. Their cilia may form a continuous row, or be grouped more or less by there being prominences in the part to which they are attached, or they may be disposed on two separate processes and so form, as it were, two distinct wheels, for, when in action, the processes and their cilia wonderfully simulate the appearance of rotating wheels: they are thus disposed in the common rotifer and in Philodina. Rotifers have also a buccal apparatus, with strong and moveable internal teeth for the purpose of mastication, a digestive canal with glands, generative organs, muscular and nervous fibres, sometimes eyes. Some of them are easy to be met with in winter, others not; we find that neither Rotifers nor the lower Infusoria often resist freezing. Melted ice contains nothing living-so glacial dritt or boulder clay seldom contains organic remains. Some Infusoria have been proved to have the power of reviving after being dried up, and this several times in succession, or after a long term of desiccation. Yet I have strained off the Hydatina senta by means of a piece of fine cambric, or rather caught it as in a net, and then dried it for twenty-four hours, and it did not survive in this case. Rotifers are soon asphyxiated if deprived of oxygen in closed bottles, and it will be found that the Entromostracea are very destructive amongst them. Infusoria are most beautiful, when viewed by the help of the parabola.

The enemies of the Rotifers just mentioned-the Entromostracea-are themselves favourite objects with microscopists. Canthocamptus abounds in seawater, and another species, remarkably quick in its movements, is not rare in fresh, where also Diaptomus castor occurs, often stationed upright, with its straight and abrupt antennæ stretched out horizontally, like the 
316 NEARER HOME-A'T HOME-WINTER EVENINGS.

balance pole of a rope-walker, and its bags of eggs hanging below. Candona similis occurred with it, and in the marine tank a species of Cypridina is common. I noticed the Argulus foliaceus, this hot summer, to affect the white fish in one pond so much as apparently to be the cause of the death of many, and some of the fish so destroyed were upwards of a pound in weight. 
UNDERGROUND_FOSSIL-IIUNTING.

\section{CHAPTER XI.}

\section{UNDERGROUND-FOSSIL-HUNTING.}

If one door be shut against us, we must seek another; if one field of pleasure and research be marred, we must go elsewhere. If Nature's sunny face no longer smiles, we must search for what Mother Earth conceals in her bosom. Where the early pursuits and wanderings, alluded to at the commencement of the first chapter, took place, was then a rather picturesque and rural scene; but beneath the surface, ' under ground,' it was fixed by fate, or, to speak more seriously, by Providence, that a vast deposit of coal and ironstone should lie buried-untold wealth,- - about thirty available seams of the former, and the latter in proportion; though, of course, only a few of such beds rise up to reward the search of the miner at any one spot. Fuel and ironstone must be had. There stood our fair domicile, in garden and grounds of plaisance; but unfortunately one's progenitor, who built the place, was not so far-seeing as some. The minerals owned another lord, and not only was the building eventually made a wreck, but the bright smiles of Nature were defaced. The 'prior's field,' where the house was built, was but a long leasehold from a nobleman, whose ancestors became the possessors, at an easy rate, of a certain Augustine Abbey, and, what is more, of its lands, of which this was part, and of the almost undreamt-of minerals 
beneath the surface. As well for the good of the world, perhaps! So with John of Gaunt's, 'time-honoured Lancaster's,' forfeited domain, close at hand. Both are now made to render up their subterranean richesgreater, perhaps, than those of a gold district-though to the inconvenience of those short-sighted mortals who have only purchased the surface. Few are the spots of freehold here, and these principally glebe or church property. Ye builders of houses! Ye founders of families, anxious to perpetuate your names! Choose not any other tenure than freehold, or your tiles will shake over you, your walls leave the perpendicular in toto, or one of them will, in miners' language, 'slip' from its neighbour, owing to the sinking of the surface! And from the last cause your little liills may become valleys, whilst you may have, instead, mountains of black bass or shale thrown out of mines or openworks. A friend, somewhat of a wag, was of this wiser opinion, and for a site for his cot went to the lay proprietor of the glebe, a long-headed lawyer, who understood the merits of a freehold. 'Isaac,' said the seller, after the bargain was struck, 'you ought to understand what you obtain when you buy church lands. No tithes; no miner dares come near you. You need not fear those tall smoky chimneys, nor ironstone roasting. Above, you may look up to the clear heaven-all is your's; and below you go down to __' 'Ah, I understand you, Sir,' interrupted Isaac, 'but you need not put all that into the writings.'

Formerly, as one stood upon some elevated spotone of the adjoining or superlying rounded hills of the denuded New Red Sandstone-and surveyed the wide sweep of ralley, there might be seen, here and there, a good-sized village, and here and there, upon 
some rising knoll, or embosomed in some pleasant shaw or grove, the residences of the then yeomen or gentry, each of these spots, perhaps, having a history which it is now curious to trace-tales, it may be, of love or alliance, of family feud, or of achievements in arms or arts. Now, all the once lords of the soil are forgotten and uncared-for. A few imperfect documents, the crumbling memorials in the churchyards, or the registers within the sacred buildings, must be scrutinized to tell us who once ruled or obeyed, loved or hated, rejoiced or sorrowed, where we, in prim villa or grimy street, do now. Ascend the same eminence now at dark, and what a different aspect! A thousand lights, a liundred flickering flames from forge and furnace! Once, at least by day, a quiet, pleasant, sunny valley; now, by night, a smoknng and blazing Tophet, wondrous and grand! Formerly one might have noticed, in some sequestered dale, or on some scrubby eminence, a heap or mound of shale, betokening a mine, worked by a horse-whimsey; or, it may be, a few coals were here and there got by means of a foot-rail or gallery driven into the coal-seam from the surface. Ironstone in these days was nsed as a building material, and zinc ore from the neighbouring limestone was thrown upon the roads. The splendid pyrites used to be attractive to boyish eyes - 'Surely this must be gold.' I delved and excavated, sought out clays and minerals, and submitted them to fire, and was in a fair way to become a miner, or at least a metallurgist; such perhaps must be one of the early propensities of our nature. Sometimes strange markings, and sharp bent objects, like teeth, as well as shells, purzled me not a little, as I beguiled the idle hour in cutting the thin laminæ of shale, or using its smooth surface for drawing upon. Years after such 
appearances rere recollected and searched for again, and not in vain; teeth, plates, and armatures of fish were again found. But every year the rural scenery of my youthful haunts has deteriorated. Many a shady lane, many a pleasant slope, prolific in ferns, periwinkles, wild hyacinths, oxlip, and red orchis; many an ancient patch of oak and holly forest; many a rocky dell, where the stream trickled down over stairs of grit or beds of shale, and where grew pretty and rare polypodies in perfection - all are gone; even the sturdy oak and stem holly soon die in a contaminated atmosphere, though they, as well as ferns, naturally abound on coal strata, as did the latter in ancient geological times; and we may couple the Equisetacer alsowitness the pretty $E$. sylvaticum, seldom absent from the surface of the coal measures.

Those coal proprietors, whether lords of the freehold or simply paying a royalty, are often magnates in the land. Good round sums of money pass through their hands, yet they run some risks. Faults in the measures may cost a few thousands extra; a bed of coal may suddenly cease; it may have slipped up or down-but which, and how far? An influx of water may render an immense amount of wealth unavailable; and one kind neighbour has been known to drain his own mine at the expense of his friend's, situated on a lower level. They sometimes try to ruin each other by expensive litigation. Still, many of them have rapidly risen to wealth, even after handling the pick themselves. Such a man was Jemmy Delves. All he did succeeded with lucky Jemmy. He had more money than many a prince, and more bone and muscle at his beck; and he knew well how to command their owners. At an early stage of his career he excited the jealousy of other 
proprietors; his transactions must be confined to narrower bounds. There was advertised to take place in the neighbourhood a sale of mineral property, and a plot was laid to prevent his purchasing the estate, or, at least, to run it up to an extravagant price. The great ones laid their plans well, but Delves got wind of them. At the sale the two gentlemen appointed to bid against him first sounded Jemmy. He doffed his hat and bowed most humbly, saying he could go to 7,000l., and no more. This was all they wanted to know. They themselves would take the property at a higher price, and even run the risk of bidding much more to keep it from him. It was put up, and that sum bidden by Delves, who then said he had done. 7,100l. bade the others. A pause-no bid; the auctioneer raising his hammer and looking at Delves, who, however, did not respond. 'Oi'll gie yo a hundred pound moer than that last gentleman' arrested the hammer. The voice came from the corner of the room, where sate a stupid-looking collier, with a glass of the strong drink so freely supplied on such occasions. The bid excited a titter at his expense. 'Who are you, Sir?' inquired one of the two gentlemen. 'Oh, it matters nowt moi name,' and he repeated his bid. ' $\mathrm{He}$ is in drink,' said the two gentlemen; 'we are the last bidders. Knock it down at 7,100l.' 'I are na drunk no more no yo,' exclaimed the man. 'I'll pee the deposit if yo loik.' The auctioneer hesitated and wavered. 'You hear what the man says, gentlemen,' said he, addressing them, and pointing to him in the corner. 'You must knock it down to us.' 'I cannot, unless you advance.' 'At your peril, then,' said they. ' 7,200l.' said the auctioneer; ' going at that -going-gone!' 'Now, Sir, give in your name,'ex- 
claimed the two gentlemen at once. 'Oh, I tould you moi name did na matter-it's Jemmy Delves as buys.' 'By Jore, we're done!' said one g'entleman to the other'; 'let's be off'!'

Collier's and forgemen are stickler's for high wages, and are often unreasonable in their demands; but they seldom lay stress on the especial circumstance which might lead one to listen favourably to such demands-their exposure to danger. The employment of both is unhealthy, and consequently life is short with them. They rarely look florid, their work being hot, and light and good air deficient. Their violent labour also leads to strain of the great circulatory centre, and their breathing organs become loaded with carbon. Many are the accidents, too, which they are liable to meet with. Miners get broken limbs or broken backs from the fall of stone, a fertile cause of mischief; their hands or fingers are very often mutilated, burns occur from the explosions of firedamp, and destroy many, or are incurable in their effects. The blasting by gunpowder often produces blindness, and in some cases wounds as terrific as those of shells, forcing pieces of coal or stone into the kody, even the verybones. Furnacemen, forgemen, and puddlers have to handle and master iron with naked arms, and to face it at white heat. The strain is great on the limbs; their palms become like the iron they manipulate, and their skin transpires like a sieve the liquids which they pour in. They are liable also to make too near an acquaintance with the heated or liquid metal, a shoeful, or a splutter in the eyes; yet withal both classes are jolly enough, and, on holidays, smart enough, too-man and womanfond of gay colours, gaudy neckerchiefs, plush waistcoats of orange or red, and handlerchiefs of bright 
India pattern. No doubt colours have extra charms for colliers, accustomed as they are to grim night. Their ranks are reinforced principally from the Welch, who, like their Cornish brethren, are great in mining. affiairs. They seem to think little of questions which one supposes would interest them, such as the origin of fossils or of mineral fuel-that is, if their attention is not specially drawn to these subjects, when, in fact, they will collect and become good aids. I once made inquiries for some one who might pick up a few thing's for me. 'Sam's the man,' exclaimed two or three colliers. 'He's good for nowt else,' put in another. To Sam I was introduced, and inquired if he ever found any fossil fish, plants, or shells. 'Oh, yes,' said he; 'I have a fish at home-a petrified salmon-nearly a yard' long, its mouth, and eyes, and scales quite perfect.' I insisted upon going to his domicile for it, and such a place it proved! A broken table, one chair, and a log of wood were the furniture below stairs, on which last a wretched wife with an infant was sitting; and yet the man was no drunkard-simply a 'ne'er do well.' The fish turned out to be only a worn Stigmaria, which the man knew as well as I-at least, that it was no fish. 'Well, bring me all the shells you can find,' said I. A day or two after he came and emptied a sack of them before me. They were all fine black tumid mussels, but I disclaimed against their being all of the same kind, as I did not propose to eat them, and only took a dozen or two from the heap before me. Afterwards the fellow took to the trade, and now goes by the cognomen of 'Sam, the fossil man.'

The coalfields of England commonly repose upon the Mill-stone grit and Mountain Limestone, or upon 
still older formations, as the Silurian. Before they were formed, therefore, lands existed in the ocean, composed either of carboniferous limestone or older rock. Such ocean must have still continued to produce its peculiar animal forms whilst the coal strata were deposited, because, at the base, and indeed far up in the coal series, at intervals, are found marine shells, as Aviculo-pecten, Lingula, Discina, Goniatites, and some other forms, analogous to those found in the limestone. But the scarcity of such remains upwards in some coalfields appears to show a more recent production of such fields than that of certain others, where beds of marine limestone cover them over. $\mathrm{H}^{\top}$ ith the marine fossils it appears rare to find any of those shells formerly called unios and anodons, whilst they are common with plants in the shale or ironstone. As many of these plants are ferns, may we not consider both shells and plants to be either land or fresh-water productions?

No doubt a great length of time must have been taken up in depositing the four or five thousand feet of the coal-measures, twice as many feet in other instances; still, it is probable that coal plants were of rapid growth, and the coal and accompanying strata of pretty rapid formation. The trunks of Sigillaria, which we see standing in the natural position as they grew-that is, at right angles to the beds-are of considerable length, and often extend through many beds of clay or sandstone; yet they are found to have been hollow, and to have been filled up with clay or sand, whilst other fossils have become deposited in their interior. They must have stood in the hollow state whilst some feet of the surrounding deposit took place. Though the stump of a tree will stand for ages, yet one fancies its hollow shell scarcely 
could. Many of the fossil fish and shells are very small, and the ferns commonly, but not always, want fructification. Such considerations may perhaps point out the prevalence of frequent inundations during the Carboniferous era, but from what particular quarter or cause they came seems more difficult to decide.

Did the plants grow on land, little elevated, with a moist and warm atmosphere? Coal strata, as they are now, extend from one or two thousand feet above the level of the sea to two or three thousand below it-at least, in the tract of country in question. Great and many, therefore, must have been the depressions of land before all the beds were deposited, and there must have followed, also, a considerable elevation. That coal was formed from plants grown on the spot would appear evident, from the wellknown facts relating to the Sigillaria already mentioned, its roots being generally found in beds immediately under the coal. On the other hand, that some of the plants were drifted appears to be indicated by the structure of certain coaly beds, evidently made up of fragments, which are also found in the strata generally. The prevalence of ferns shows the vegetation not to have been marine, and the charncter of many of the plants-Sphenophylla, Asterophyllites, and Calamites-like our star-worts, mare's-tails, and equisetums, proves that the surface was marshy, and the atmosphere damp. But the formation of coalfields puzzles us, whatever theory we take up. If we suppose them due to great morasses, swamps, or lakes, we account for the coal, but not for the intervening beds; a delta or estuary theory better explains the latter, as well as the occasional appearance of marine deposits. If, further, we are disposed to overstep the bounds of the natural and usual, as 
we see things now, and call in volcanic or igneous convulsions, then we account for the oscillations of the surface; and also perhaps for the strange appearance of the fossil fish-little creatures, apparently overtaken by a noxious or hot inundation, and who in consequence have died convulsively, the mouth wide open, the body tetanic, and the fins erect. Certain elongated elevations of sand or sandstone sometimes rise from the should-be floor of a bed of coal, taking its place to a certain altitude. From this, and from the occurrence of isolated deposits of sand-rock in a bed, and from the splitting of it, or what is called the 'flying-reed,' in which its component parts gradually diverge, and are at length found far apart, with different intervening deposits, Mr. Jukes argues that the coal, like the other strata, was a subaqueous deposit. But are not such phenomena explicable by considering them to originate from other causes-river deposits, land springs, or inundations - the latter perhaps of a volcanic nature?

Most coalfields are in the form of troughs or basins, but such troughs did not exist, or at any rate to the same extent, when the beds of coal were deposited, for in some cases the coal strata appear to have been once continuous over their boundary ridges, and in others the rise of these ridges has been accompanied by an elevation of the adjoining or overlying New Red Sandstone. It is not often that gravel or boulders are found in the regular coalmeasures, though coal-measures often repose on a bed of conglomerate called Millstone Grit, itself frequently composed of pebbles of many species. Sometimes, horvever, such beds do occur, and especially ligh up in the coal-measures, in the form of a very hard conglomerate; and sometimes, too, is found a 
greenish or yellowish rock, containing many rounded pieces of hæmatite, or red ironstone. The former conglomerate is often accompanied by beds of silicious limestone with entomostracea, and looks like a volcanic detritus. Commonly coal strata throughout, up to the Permian, are evidently the result of the deposit of fine particles of matter once suspended in water. We cannot help connecting the oscillations of the land and the elevation of the boundary walls of a coalfield with the intrusion of basaltic rocks into the coal-measures and Mountain Limestone, and no doubt justly so; yet in the coal-measures Greenstones occur in conformable beds, and may have been deposited upon or injected between the coal strata long after they were formed; and darker coloured basalt has been very evidently poured out over the coal, the latter being often charred by its proximity to such rocks when incandescent. Igneous dykes even penetrate the red sandstone, deposited later than the coal strata. The horizontal beds of igneous rock are themselves often cut through by faults; and thus it appears that this last phenomenon (that of faults) is less connected with igneous action-at least with igneous action of the earliest date-than the elevation of the ridges of limestone, of the coal strata, and even of the New Red Sandstone. Faults do not generally interfere with the direction of the bedding; for though they may go up or down many yards, the beds continue commonly in the same horizontal direction. The dislocations which have inclined the strata give their character to the surface, and form the trough or basin, with its surrounding ridges; on the contrary, faults, generally speaking, have left no indication on the surface of their existence, denudation having taken away all inequalities left there; in 
fact, it must have carried away vast beds of more recent deposits, in some cases leaving patches or ridges of them, especially when they have been depressed by faults below the level of the adjacent coalmeasures.

What the history of a coal district is, after the deposit of the Permian or of the New Red Sandstone upon it, seems a mystery, for generally there appears no trace of later formation-lias, oolite, or challk-upon the surface; though in some cases lias or oolite does immediately succeed, the red sandstones and clays being absent. Generally, however, the boulder-clay and recent drifts are all that we now find upon the surface of coal strata, and what is remarkable, these clays and drifts rarely present fragments of any rock newer than the coal-formation itself. The beds of Bunter-sandstone gravel, at the margin of coalfields, appear to be component members of that formation, the interstratified sands often becoming sand-rock. Many pebbles from this gravel are of red quartz, marked with cloudy spots, commonly, but perhaps doubtfully so, attributed to pressure. Gravel, with chalk flints, only occurs at a distance southwards from the coalfield which is especially under consideration. There is another rough gravel in the lower grounds, of largish pieces not well rounded-pieces of Mountain Limestone, Millstone Grit, basalt or greenstone, and ironstone. Boulders of granite from the boulder-clay present surfaces rounded by a grinding or sliding process, as well as scored-of which we have convinced ourselves ; and the Millstone Grit in situ, besides presenting surfaces rubbed smooth, apparently by dislocations, offers, beneath the soil, the marks of stones having slided over it. Small coalfields are sometimes elevated 
far above the hills of New Red Sandstone; often, however, denudation has left their surface much lower.

But, leaving the above theories and suppositions to those more capable of entering into geological speculations and reasonings, we will confine ourselves for the remainder of the chapter to more unpretending remarks. Whilst the Mountain Limestone is distinguished by its abrupt hills, deep dales, and pinnacles of blue-grey rock, and by a peculiar vegetation; the Limestone Shale, by a broader sweep of surface, dark commons, shivering declivities, and ochrey rills; the Millstone Grit by its rugged and barren surface, and grey rocks of shattered and wild appearance-though some of the little intakes look beautifully green by contrast-the Coal Strata generally constitute a tamer country, except along the lines of disturbance, where it is often more varied; and the colour of the soil, so unlike the bright red hue of that of the limestone or New Red Sandstone, betokens to the habitué what is beneath. On the grit the vegetation is marked by the bilberry, cowberry, cloudberry, and crowberryrarely, if ever, found on the limestone. In the gullies formed by the grit and shale the little streams often fall in pretty cascades, and in the bushy places we may sometimes find Pyrolæ, Valeriana Pyrenaica, and Saxifraga umbrosa, the two latter thoroughly established, but not truly wild; also ferns of two or three rare species. On the grit moors also grow, very commonly, Fumaria claviculata, and Rubus plicatus. On the shaly refuse of the coal district there are a few prevalent plants-Reseda luteola, Hieracium sabaudum, H. sylvaticum, Genista tinctoria, and G. Anglica. The oak, though small and slow-growing on the coal strata, is said to afford stronger timber than from elsewhere. 
In fossil-hunting, we may often pick up portions of Stigmaria upon the surface, or in the gravel or clay found upon the coal strata; the little brooks in the rocky hollows will present us with sections of the lower beds, with Lingulæ, and other marine fossils. The great pits for the digging of fire-clay afford shells and vegetable remains, as well as remarkable sections of the coal strata; the Millstone Grit contains impressions of Sigillaria, and Calamites; and its flags, markings and castings of annelides, besides largish impressions of shells, which liave not obtained much attention. For fish we must search the immense heaps of black bass thrown out from the coal-pits or open works, and especially that which accompanies the ironstone. A lucky split here may furnish us with a beautiful and perfect Palæoniscus or Platysomus; or, finally, we may descend the pits ourselves in hopes of meeting with fossils-at any rate with objects to interest us.* Here we shall often see Sigillaria trunks in position. We must, for the last undertaking, don the miner's coat and hat, and shall, perhaps, have to sit in the loop of a chain, with our legs dangling below, whilst we descend two or three hundred yards. Such is considered not an unsafe mode of descending, and we have done so several times, a kind of iron umbrella being over the head, to protect from any accidental fall from the pit's mouth. On one occasion we were to be landed at the mouth of a side gallery, going off from the shaft halfway down, and proceeding till it struck an upper slanting bed of coal; when we got to the gallery a sliding door was to be shut across the shaft on which we were to land, but, being unexpected, no one was

* On the timber various Fungi are seen, Thelephorus, Merulius, \&c. 
there to accomplish this. My companion, a collier, shouted in vain for Bill, but Bill was far away in the bowels of the earth. 'Just stay a bit, master,' said the collier, 'you are quite safe. I think I can manage to land.' He did accomplish this, leaving me hanging over a dark abyss called the sump, I know not how deep, and half filled with water. I was presently landed, and now he said ' I must find Bill before we can go on ; you sit down here whilst I go after him.' I heard his voice echo through the galleries, 'Bill, Bill!' and at last a distant halloc responded. As Bill's half naked, begrimed, and crouching form made its appearance, candle in hand, and in distant view, no ghostly apparition could be more effective. The mines-at least some of them-are dreadfully hot; those of ironstone, it may be, from want of ventilation, and those of coal from the heating of the refuse in the waste. One or two of each kind of mine will be quite enough to visit: it is no joke to walk a mile in the crouching position, or to creep on hands and knees along a gallery half as long; though colliers seem when at rest to enjoy the unnatural positions they are accustomed to. Things are now done in the subterranean world in the best style, and coal is often got at the depth of 1,500 feet, or deeper ; far short, however, of the depth at which Mr. Hull supposes it will be possible to get it-4,000 feet.

Miners, like other men, are of all characters-prudent or reckless, sensible or ignorant, religious or reprobate; too often the carelessness of one man leads to the death of his fellows by inflaming the dreadful gas mixture. An explosion takes place, perhaps many are killed, a jury is summoned, and the inspector gives his opinion - when the mischief is done. Individual rashness and stupidity will never be prevented, 
but often the whole gang is regardless of danger, or there may be no capital to work the mine safelythat is, with means calculated to ensure good ventilation. Explosions are apt to take place when the extrication of gas has been faroured by an unusual lightness of the atmosphere. It appears probable that if, instead of forcing the ventilating air, by means of valvular doors and such contrivances, a mile or more through the workings, and then finally bringing it, mixed as it is with the light inflammable gas, to the bottom of a shaft on the lowest level, some plan were adopted, combining a less circuitous route with an exit for the air and gas at the highest point, much danger might be prevented. A ready method of quickly producing the absorption of the after or choke-damp, and of enabling a person to traverse it without asphyxia, might often prevent loss of life.

We have heard a tale of the adventure of some professor (or commissioner may be) who had descended a pit to inspect it; he was assured that they were all very careful in that colliery. After collecting the workmen in one of the more open spaces, he commenced to lecture them upon the prudential working of the mine. They were not to unlock their Davy-lamps, or light pipes at them; the trap doors were to be carefully attended to, and, where blasting was allowed, they were to use certain fusees; and 'your gunpowder,' said he, 'where do you stow that?' 'The powder he means,' said one. 'Why, to tell you truly, it's in the little keg that you are sitting on.' The learned lecturer immediately rose.

Coal mines being limited in depth, as described above, we can only ascertain the total thickness of the coal-measures by measuring them at their out- 
crops, or where they rise to the surface, which they do (in the field described) at the rate of one yard in four, but at other spots the rise is much more precipitous; or we must calculate the distances from one known coal to another as they are worked at the different collieries along the outcrop, and we shall thus get the whole series; for the coals are won or sunk to as they become available in depth by their natural rise. Some are rendered accessible from the upper measures having been carried away by denudation, which denudation must, in some cases, have taken place before the New Red Sandstone was deposited, as the lower beds alone sometimes go under it. Thus, by the modes mentioned, and in the coalfield in question, we at last get a section of about a mile in depth, and through this thickness there are about forty beds of workable coal. Beds of clay with Stigmarix occur, as said before, beneath the seams of coal; in one or two cases there are thick layers of coaly ironstone immediately above the coal, in which position the ironstones always lie, and on these vast lumps, when raised, is seen a length of Stigmaria on every one, with its branchlets attached, and of a dull green colour; also shoals of small mussel shells (Anthracosia); the whole vegetable and animal remains being unusually flattened. Several beds of rather silicious limestone are seen high up in the series, with remains of small spirorbes and fish fragments. The ironstone layers commonly occur two or three together, separated by bass; but the carbonaceous ores mentioned just above are more massive, and calcine with their own combined coal, or with a little unore fuel. Ironstone is often concreted into nodules with organic nuclei-fish or shells. About 270 yards down, marine fossils, as Lingulæ, 
occur in one bed, and also at another point in the series; and at the base again are several beds of marine formation. Commonly, as observed before, Anthracosiæ, and shells of that character, do not occur with these last. The so-called upper beds of coal strata for a thousand feet or so are umproductive in coal; then come (in the case in point) measures with coal, iron-stone, and abundance of fossil shells and fish; lower down, deeper beds, separated from the last by a thickness of sandstone and other coal-measures, and producing the best house coals, but no ironstone; and, lastly, comes the deepest series, with few coals, and some of them sulphureous, or stinking, as it is called, but with a bed of valuable red ironstone or earthy hæmatite, also with an abundance of marine fossils.

From the uppermost beds to the lowest of the coalfields remains of fish occur, and the same species throughout; few, if any, species are peculiar to one stratum. If the measures took countless ages to deposit, then species continued for countless ages unaltered. Like the Mollusca, the Ganoid fishes found, with the exception of a few giants, were of no considerable dimensions. The Placoids, however, were no doubt of good size, judging from their teeth and armatures, but their remains are mostly fragmentary. When we ourselves began to collect remains of coal fishes, they were but little known in Finglish coalfields; now in a small field remains of forty or fifty species have come within notice. Sir P. Fgerton was about the earliest searcher in the field. Our first finds were handed over to M. Agassiz, and one specimen proved a new Holoptychius, now, however, named Rhizodopsis. A young collector might meet with little success where these fossils in 
reality abound-so much is there in identification and classification, and knowing where to look. The specimens consist not only of fragments, such as teeth or scales, but of entire fishes, and in the most perfect condition. The searcher must split up the shale, and, what is harder to do, open the ironstone nodules. I have found teeth of Megalichthys in the coal itself. There is one thin stratum, in the coalfield described, of a shaly nature, almost entirely composed of fish remains in the fragmentary state-- teeth, scales, bones, armatures, and coprolites. The Placoids, analogous to our sharks and skates, are, as observed before, commonly found in fragments, and some of their teeth are very like those of living genera. Occasionally a portion of their slin or shagreen is found, sometimes with dermal appendages, as we see in the thornback skate. One would suppose such creatures to have been marine. Their tails were heterocercal, like that of a common dogfish, as, indeed, were those of the Ganoids-the only other division of tishes found in the coal strata, and having, unlike the Placoids, a skeleton more or less bony, and the covering formed of bright enamelled scales or plates. The disarticulated bones of fishes which are found are puzzling enougl, and it requires an accomplished ichthyological anatomist to identify them; some are more than suspected to be reptilian. One common bone in shape reminds us of a boomerang, or of the curved instrument or weapon seen represented with Egyptian figures; it may be an armature or a supra-spinal bone; another, of a large size, and halberd-shaped, but varying somewhat in form, is found; one would suppose it to belong to the base of the skull. Loose cranial and opercular plates are often met with, sometimes prettily sculptured. 
Amongst Ganoids the scales or plates of Megalichthys are the most common ichthyolites, being of considerable size, of a lozenge-shape on the body, and covered with shining enamel. Dr. Hibbert, its discoverer, at first considered it to be a reptile; and, indeed, in some respects it is unlike other fishes. Its body was clad in complete scaly armour, and large punctured plates inclosed the head-a combination of scale and plate, as in an ancient warrior of Crecy. Its teeth are formidable-at least the larger ones, for it had two kinds-the smaller in a continuous row, the larger distant, and received into corresponding pits in the opposite jaw when the mouth was closed.; there were also numerous minute teeth or points within the mouth. This creature has seldom, if ever, been found perfect; the writer procured one smallsized specimen, consisting of rather more than the posterior half of the fish, but quite perfect; 'the head and shoulders' gone. The fish had two dorsal fins. The vertebre are often found, in the form of bony rings, and in rare instances their appendages are seen attached. There are at least two other species; in one (Rhomboptychius, Young) the scales are larger, but not shining, the ganoine being probably decayed away. The teeth of this had several circles of pitted marks. In another lozenge-shaped scale the markings are V-shaped behind, and prettily crenated. Holoptychius, another large fish, only occurs in fragments, and is not common, at least in the typical forms. These fragments consist of large plates, round or oval, with ridges behind variously patterned, but smooth before. It also had teeth of a conical form, and deeply striated. Rliizodus is the name applied by Owen to certain forms of carboniferous fishes formerly considered to be Holoptychii. The 
teeth are of large size, and compressed, and the scales are roundish or oval, irregularly tuberculated behind, but concentrically striated in front; the cranial surface is apparently in some cases peculiar, having been covered with pits with a tubercular prominence at the bottom, as is the case, too, in Holoptychius. The teeth of $R$. lanciformis of large size were found by the writer many years ago. They are not very common. It is a compressed, lancet-shaped tooth ; the jaw had the pitted markings as described above. Another tooth, R. sauroides, or Strepsodus sp., is curved at the top, but the very apex again a little turned up; it is also covered with fine parallel striæ, and is rather compressed. Other scales belong to $R$. granulatus and minor; and a large jaw, or rather head, in the possession of a friend-whose aid the writer has borrowed in this account of coal-fossilsit is difficult to decide whether to refer to this genus, or to consider it reptilian. Scotch specimens show that some of these fishes must have been giants; with us they are smaller. Rhizodopsis has its roundish scales concentrically marked, with two dorsal fins, and the pectoral ones large and lobate. It is commonly found in the centre of an ironstone nodule, and is about a foot in length. Its tail is lozengeshaped.

Cœlacanthus is found in shale, or more perfect in ironstone nodules; the jugular plates and the rest of the head plates, as well as the scales, are thin, but beautifully marked: the scales are circular, and boldly sculptured with triangularly disposed lines. The teeth are mostly sharp, and the ossified air-bladder is sometimes preserved in situ. Its characteristic fins are composed of hollow rays or spines, whence its name, hollow-spine. Pygopterus is a genus remark- 
able for the development of its dorsal and caudal fins. Gyrolepis and Acrolepis are weakly defined genera, the latter having the scales pointed behind, and with thick ridges. Many species of Palæoniscus are found. The scales are very bright, squarish, variously marked by furrows or granules; the teeth sharp and fine. In Cycloptychius, Huxl., discovered by a friend, the scales are of a roundish form, very thin, but strongly ribbed; the teeth the same as in Palæoniscus, but the dorsal fin nearer the tail than in that genus. Acanthodes has minute rhomboidal glittering scales or plates; the fins are all armed with swordshaped spines, to the concavity of which the scalecovered fins were attached; it is commonly found fragmentary, but sometimes perfect; and a new and larger species has lately turned up, named $A$. Wardi after the discoverer. Probably Amblypterus occurs; it had a deep body and large fins. The Platysomi are often found, looking like pretty little soles or turbots, but the eyes were not both on the same side of the head, and the scales were long and narrow, and ornamented with parallel striæ; the anal and dorsal fins were extended behind to the tail, the pectoral fins placed close to the head, the teeth in one row, sharp. Amphicentrum, Young, differs somewhat in generic characters from Platysomus; its scales are similar in shape, but granulated. The teeth are blunt and more suitable for crushing, the dorsal and ventral margins of the body sharply angulated. Mesolepis has ventral fins, which the last mentioned genera had not, and teeth in the form of blunted cones on peduncles with constricted necks. In Eurynotus (Agassiz) the plates are toothed behind. Diplopterus carbonarius, of which only scales are found, is the last of the Ganoids on our list. 
The Placoids have left strange-looking teeth, and what are called ichthyodurolites, or offensive armatures or weapons, some of them powerful and murderous enough, and showing us that carboniferous waters were sometimes ' waters of strife.' The Pleuracanthus is a spear or stiletto of no great size, a span long, but barbed on both sides for much of its length with sharp recurved spines. I have a perfect specimen in cannel coal. A second species has the stem more compressed and more gradually tapering. This spine has been found in connection with the curious teeth of Diplodus. The Orthacanthus is a much larger spear, eighteen inches long, the double row of spines being on the same side. Leptacanthus is found in the coal formation as well as in the lias ; it is grooved, curved, and with blunter teeth than the preceding. The true Onchus is found, but certain sword or scythe-shaped armatures, similar to the spines of Acanthodes, hardly belong to Onchus. Gyracanthus was as much a club as a spear. There are two species pretty common-G. formosus, "the handsome twisted spear'; and G. tuberculatus, 'the warted twisted spear.' Ctenacanthus ('comb spine') was equally or more massive, and had parallel longitudinal ribs, which were also tubercular behind. All these weapons, if such they may be called, present a contracted surface below, by which evidently they were imbedded in the soft parts of the animal, and not articulated to its skeleton, which was probably cartilaginous. The teeth of these Placoids are many, and some of them as remarkable as the spines, especially beautiful when prepared for the lens. Helodes is a bluntly conical tooth, recurved somewhat like a Phrygian cap, and pitted in front. Diplodus is one of the commonest of fish remains-a 
tooth of two fangs, with one or two smaller ones between them. These fangs are rather curved and somewhat compressed, also with a tendency to serration at the edge; the crown is broad and rough. This crown is, however, in reality the root by which the tooth was attached, though the shape reminds us of that of a human grinder. There are two or three species, one much smaller than the common $D$. gibbosus, and another with many close-set fangs, perhaps a palatal tooth. Pleurodus is a compressed palate, convex, and with several transverse wavy lines. Pæcilodus is also found. Ctenodus cristatus is a palate found first by the writer (at least in the coalfield described) : some curved spines or bones accompany it. It is raised into a longitudinal ridge, with other transverse ones, themselves bearing tubercles. Ceratodus, another fish-palate, also occurs. Ctenoptychius is a curious tooth, and especially so when it is ground down for a microscopical object. It reminds us of the teeth of some dog-fish. There are three pretty common forms-C. apicalis, C. pectinatus, and C. denticulatus. Cladodus is another tooth occasionally found, and portions of the shagreen covering of the fish have been seen with it, and also of the Ctenoptychius, much more entire.

Minute Crustacea (Beyrichia and Cypris) are plentiful with the above fish remains-that is, in certain beds. Some objects, like the sand-tubes of Annelides, occur, straight and conical, similar to those of Pectinaria. The two-muscled or dimyarious shells, more than once alluded to, were formerly considered to be fresh-water mussels or allied species. This now is doubted, perhaps without good grounds ; they are also subdivided and defined under the names Anthracomya, Anthracosia, Anthracoptera, Myalina, and so on. 
They certainly appear to be more characteristic of the different beds than the fish remains are. Anthracoptera presents an appearance under the microscope of beautiful shell structure, like that of the Pinna. Some of them are found in the position of burrowing. From an examination of the hinge by grinding down, \&c., they may most of them be pronounced to be anodons or unios. The little Spirorbis or Microconchus is often met with adhering to Anthracosiæ. The decidedly marine shells of the lowest beds-Orthoceras, Goniatites, Melania, Aviculopecten, Posidonia, Lingula, and Discina-are frequently bright with pyritic deposit; the laminæ of the two last form objects for the microscope, displaying beautiful cell-structure.

One may meet with Sigillaria and its roots (Stigmarice) in tunnels, in railway-cuttings, and in claypits, the former marked with longitudinal grooves, and having seal-like impressions between, spirally arranged; they have been considered to be tree-ferns, and leaves of Neuropteris (heterophyllus) are certainly often found in their vicinity; it is now, however, believed that the Cyperites or grass-like leaves, so often seen, belonged to them. Certain little nuts (Trigonocarpon) have been supposed to be their fruit, and it has also been considered that both roots and stems are more like Cycadeæ in structure than tree-ferns. The disciferous, dotted, or coniferous tissue found in coal has been attributed to a conifer (Dadoxylon). Mr. Binney has shown that the stem of a Sigillaria had an inner and an outer circle of woody matter, elongated cells or vessels with scalariform markings in the centre, and also cellular tissue between the circles; bands likewise radiate outwards from near the axis to the bark, where they enter the base of the 
leaves at the external markings. He considers the fructification to have been a cone or strobile; perhaps such may have been the male, the nutlets representing the female fructification. It may be said summarily, that the Sigillaria cannot be placed with any order of living plants, but that it has a resemblance to several. The Stigmariæ are cylindrical, often compressed, pitted, and with rootlets growing from the pits, these last, however, undivided. They are often seen attached to the Sigillaria above, coming off in a cruciform manner in four great trunks, and these latter dividing each into two at a regular distance of two or three feet from the central trunk. These roots-for roots they must be-often appear as if split, displaying a central fibrous bundle, sometimes quite loose, and they appear to have opened the more easily as the external rootlets extend to the inner axis. The rootlets inwards appear much compressed, and present the appearance of a pinnate leaf -of a Blechnum, for instance. The large Stigmarix, or main roots, appear to be compound or made up of several. Curiously enough, too, as alluded to before, other fragments of vegetables, and also shells, are found within the Sigillaria trunks, almost invariably. The fire-clay especially abounds with ferns and Calamites, also with some palm-like fragments (Flabellarice, Cordaites), and others more grass-like, having parallel lines and midrib. One stem seems to have had amplexicaul leaves like a liliaceous or grassy plant, but it may be a Sternbergia, that is the inner cast of the pith cavity of some plant. The Calamites are found throughout the beds, and some species in the Permian and Millstone Grit; they sometimes seem to have been broken by superincumbent pressure, having a space at the margin destitute of the or- 
dinary longitudinal and transverse markings seen elsewhere; but here, again, some of them are considered to be Calamodendra, or inner casts of such plants as Sigillaria, formed after its medullary tissue had decayed. True Calamites had whorled leaves or branchlets at their joints. From certain large, somewhat cordiform masses of ironstone, cylindrical hollow stems (Leioderma?), having often pyrites, blende, or calcareous spar within, smooth externally, but with two obsolete lines, and tapering off to a point above, appear to have sprung. There are also occasionally found convex hemispherical bodies, tuberculated on the convexity, and with four slight prominent lines in the centre, and cellular within; what they are we cannot decide, nor what other similar but smaller ones may be. We have already mentioned the little oval fruits or nuts with three ribs, - they are very like the fruit of some palms; there are others with a depression at one or both ends, striated or not, and more or less ovate or oblong. There are also strata some inches thick, entirely composed of little round bodies (Sporangites), probably the spores of some plant. We have likewise collected tuber-like bodies, neither coprolites nor concretions, but much like what we venture to compare them to, and apparently with eyes, or points of germination.

Of the Ferns, the spleenwort-like Sphenopteris, the Pecopteris, often resembling recent Cyatheæ, and the Neuropteris, not unlike the fern-royal in leaf, are the most common, and are often beautifully preserved. The Cyclopteris leaf, like that of an Adiantum or Maiden-hair, but of large size, occurs, especially in the centre of nodules. One species of Sphenopteris, perhaps more properly a Schizopteris, has very fine divisions ; another has a large roundish leaf or frond, 
but composed of much divided trichotomous portions, with attenuated extremities. Neuropteris is often found, with its neat leaflets varying much in size, especially at the extremity of the frond, and one species, $N$. cordata, has them very large. One leaflet, of a green colour, lying upon the dark shale, is lanceolate, and finely serrated, like a willow leaf, but it is probably a fern leaflet.

Lepidodendron is commonly found most perfect in shaly ironstone, and is one of the most common of vegetable fossils, distinguished by its scale-looking leafscars and its dichotomous divisions. When the outer coating is removed from the plant the markings are very different, being then prominent (Knorria). Sometimes such stems are variously branching with superadded markings or tubercles of different forms (Halonia). Ulodendron has the external appearance of a Lepidodendron, and, besides, the stem has a row of round scars on each side, the markings of which would lead us to suppose that they were left by large cones or strobiles. Both these last forms occur with us, but they are not plentiful; there is a larger and a smaller kind of the Ulodendron. Lepidophloias had the scale-like markings differing in figure from those of Lepidodendron, and also cone-scars. Megaphyton had the large scars at the sides, but they are supposed to have given origin to branches, such as those of tree-ferns, and the form of the plant has been supposed, when growing, to have been somewhat like that of an Indian fan, or fly-flap. The smaller branchlets of the Lepidodendron are often found with the leaves attached, and in this state present somewhat the appearance of Araucarix. In the form of the fructifying parts, Lepidostrobes, \&c., Brongniart compares them with the Coniferæ, but in other respects 
- the mode of growth and markings - with the Lycopodiums, or club-mosses, and with the Cycadex. Favularia, a common and elegant form, but usually arranged with the Sigillaria, has square markings, a good deal resembling the last-named recent plants. One Lepidodendron, or rather Lepidophloias, seems to have been a low and hemispherical trunk, that is, if it were not a large kind of fructification.

Sphenophyllum and Asterophyllites are pretty common, sometimes of great beauty of form; the first was referred to the Cryptogamia by Brongniart, the latter has had a higher place given to it in the vegetable world. All these vegetable specimens, whether in shale or clay, have little tendency to break up, if kept from air and moisture; but in the open air and rain, the strongest coal-measures, the massive and stony trunks of enormous Sigillariæ, and all other coal fossils, generally go into shivers. Some specimens may be fired in a kiln, after having been thoroughly dried from all inherent moisture; they then become indestructible. The ferns found in clay are easily rubbed or erased; a coat of fine varnish carefully applied secures them.

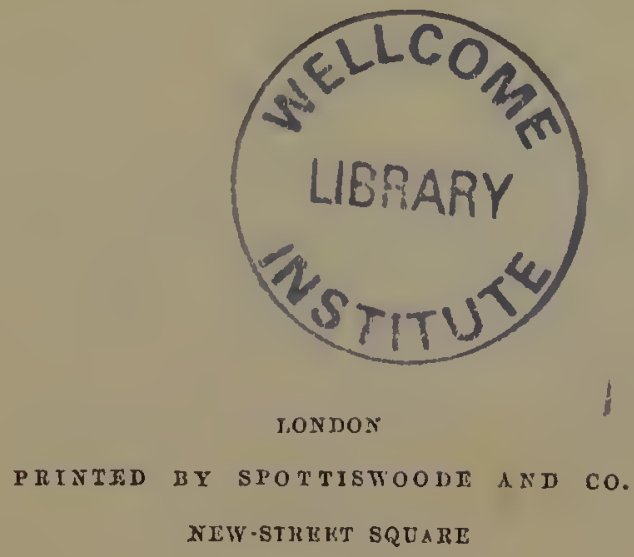

$\Lambda \mathrm{A}$ 

Just published, crown 8 ro. cloth, with 40 Illustrations, price $6 s$.

\section{AT HOME}

IN

THE WILDERNESS ;

BEING FULL INSTRUCTIONS

HOW TO GET ALONG, AND TO SURMOUNT ALL DIFFICULTIES

BY THE WAY.

$13 \mathbf{Y}$

\section{'THE WANDERER.'}

\section{AUTHOR'S INTRODUCTION.}

WHERE and when to eamp; how to equip and manage a train of packmules; break, gear, and saddle wild horses; cross streams, build $\log$ shanties, trenail a raft, dig out a canoe or build it with bark or hide, manage dog-sleighs, and tramp on snow-shoes; what to carry and what to leave at home; or, to sum up in a few words, the way to get through a wild eountry as one ought, by adopting the better means of doing that whieh has to be done, are matters of no trifling value to trarellers of all denominations. There are details that a novice cannot possibly aequire, sare it be from the past exporiences of other travellers, or, failing assistance such as this, he must learn his lessons in the field and forest by finding them ont for himself, always a tedious, unsatisfactory, and very expensive process. Bolieve me, in travelling, as in everything else, there is a right way and a wrong way of going to work, and, for some inexplieable renson, 'young beginncrs' are strangely predisposed to follow tho latter course.

The experience of twenty years passed as a rambler in various parts of the world, though prineipally as trapper, hunter, and naturalist, East and West of the Rocky Mountains, enables me to state from aetual observation, that a 'green hand,' to use a slang term, on his first visit to a wild country, in nine cases out of ten arrives from the land of civilisation complctely hampered, entangled, and weighed 
down, so to speak, with a medley of utterly useless things, which ho never would have purchased had he been guided or directed by any person who knew how to travel.

Again and again friends and strangers have sought my guidance, when fitting out to travel, either in the pursuit of sport and pleasure or to seek a fortune in far-off lands as emigrants. Hence I am induced to offer a fer practical hints on the general details of travelling, trusting the rongh suggestions I shall offer may prove of use to those who are disposed to venture into a distant country wherein wheels, steam, iron and macadamised roads, are unknown luxuries; and in which, as a Yankee once said to me, in reference to Southern Oregon: 'Stranger, you bet your bottom dollar a man has to keep his eyes skinned, his knife sharp, and his powder dry, or he'll hav' his har ris'd, sure as beaver medicine, if he travels thim parts.'

\title{
JoHN LíEAst LoRD, F.Z.S.
}

Late Naturalist to the British North Ameriean Boundary Commission ; Author of the 'Naturalist in Vaneouver Island and British Columbia.'

Just published, price $2 s$. fep. cloth, Illustrated,

\section{GUIDE FOR TRAVELLERS IN THE PLAIN AND ON THE MOUNTAINS.}

\section{BY CHARLES BONER,}

Author of 'Chamois Humting in Bararia,' 'Forest Creatures,' \&c.

\begin{abstract}
'A little book whieh compresses into a very small spacc a grcat deal of good adviee.'

Pall MIALL GazeTte.

'If all monntain-elimbers were as experienced, as sensible, and as eantious as Mr. BONER, there would be few, if any, mischances. If our young fellows will put their necks in jeopardy, the risk may no doubt be redueed by a careful observance of the rules here laid down as the result of many years' experienee.'

LONDON REVIEW.

'We reeommend Mr. BoNER's little work to all travellers, either on mountain or plain.'
\end{abstract}

ATHENAUM.

London: ROBERT HARDWICKE, 192 Piccadilly. 



